Portland State University

PDXScholar

Dissertations and Theses

Dissertations and Theses

Winter 2-26-2013

\title{
Arsenic in the Soils of Northwest Oregon
}

Tracy Ryan Ricker

Portland State University

Follow this and additional works at: https://pdxscholar.library.pdx.edu/open_access_etds

Part of the Geology Commons, and the Soil Science Commons

Let us know how access to this document benefits you.

\section{Recommended Citation}

Ricker, Tracy Ryan, "Arsenic in the Soils of Northwest Oregon" (2013). Dissertations and Theses. Paper 927.

https://doi.org/10.15760/etd.927

This Thesis is brought to you for free and open access. It has been accepted for inclusion in Dissertations and Theses by an authorized administrator of PDXScholar. Please contact us if we can make this document more accessible: pdxscholar@pdx.edu. 
Arsenic in the Soils of Northwest Oregon

by

Tracy Ryan Ricker

A thesis submitted in partial fulfillment of the requirements for the degree of

Master of Science

in

Geology

Thesis Committee:

Scott Burns, Chair

Christina Hulbe

Clark Niewendorp

R. Benjamin Perkins

Portland State University

2013 


\section{ABSTRACT}

One hundred and eighty-six soil samples from Northwest Oregon were tested for arsenic content. The highest values measured were $13.9 \mathrm{ppm}$ in the A horizon (site C4) and $20.4 \mathrm{ppm}$ in the B horizon (Site P4). Arsenic was not detected in $28 \mathrm{~A}$ horizon samples and $23 \mathrm{~B}$ horizon samples.

Data are grouped based on the age and rock type of underlying bedrock. Lithologic groups with six or more data points were compared statistically to ascertain if groups are distinct. Analysis of Variance (ANOVA) multiple comparison tests indicate that the arsenic content of the Marine Sediments and Sedimentary Rocks group samples is distinguishable from the Quaternary Basalts group in the A horizon and all other groups in the B horizon. Kruskal-Wallis multiple comparison tests indicate that the arsenic content of the Marine Sediments and Sedimentary Rocks group is distinguishable from the Quaternary Basalts, Quaternary/ Tertiary Sediments and Sedimentary Rocks and Volcanic Sediments groups in both the A and B soil horizons.

The ANOVA and Kruskal-Wallis tests compared A and B horizon data by lithologic group. The ANOVA shows the Marine Sediments and Sedimentary Rocks group in the A horizon is distinct from the Quaternary Basalts in the A and B horizon. The KruskalWallis test yielded the same result. Per the ANOVA, the Marine Sediments and Sedimentary Rocks in the B horizon are distinct from all other tested groups. The Kruskal-Wallis test shows the Marine Sediments and Sedimentary Rocks group in the B 
horizon as distinct from the Quaternary Basalts, Quaternary/ Tertiary Sediments, and Volcanic Sediments groups in the A and B horizon.

A K-means cluster analysis was used to group all available data independent of underlying bedrock. Three, four, and five group analyses were conducted, and the results of these tests were compared to the data grouped by underlying rock type. No correlation between the groups resulting from the K-means cluster analysis and groups based on underlying lithology was found.

This analysis supports the creation of a map distinguishing arsenic content in the soils above Marine Sediments and Sedimentary Rocks group units from arsenic content in all other tested lithologic groups. The mean and standard deviations of these groups (in ppm) are: A horizon: Marine Sediments (6.09 \pm 2.66$)$; other groups (3.10 \pm 3.19$)$; B horizon: Marine Sediments $(10.26 \pm 4.65)$; other groups $(3.13, \pm 2.52)$. This analysis indicates that geologic context must be taken into account when determining background levels of naturally occurring arsenic in soils. 


\section{ACKNOWLEDGEMENTS}

First and foremost, I would like to thank my committee members Scott Burns, Christina Hulbe, Clark Niewendorp, and Ben Perkins for everything they've done to help me complete this project. It is no exaggeration to say that I could not have completed this project without them. They have all put significant time and energy into helping me with this thesis, and I cannot thank them enough for their support and assistance throughout this project.

I would like to thank the Oregon Department of Environmental Quality for the funding that was imperative to this project. I would also like to thank Apex Laboratory in Tigard, Oregon for testing the soil samples used for this project.

I would like to thank Norma Friday for her assistance in the field. Her presence and hard work made the field work for this project significantly easier, and her company was greatly appreciated.

Last, but certainly not least, I would like to thank my family. Thank you to my husband Chris for his love, his support, and his incredible ability to make me laugh. Thank you to my best friend, Liza, for always being willing to listen, even when I was speaking gibberish. These two had to put up with me on a day to day basis throughout my work on this project, and I thank them both wholeheartedly for dealing with me. I would like to thank my parents, Jim and Lynn, and my sister Carrie, for always 
supporting me, for being my cheerleaders, and for sending me extra brain cells when I most needed them. You all are amazing, and I love you. 


\section{TABLE OF CONTENTS}

ABSTRACT

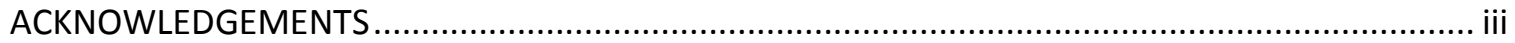

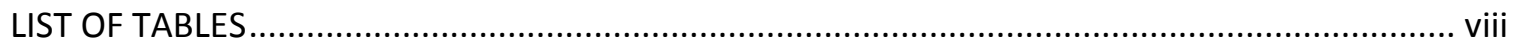

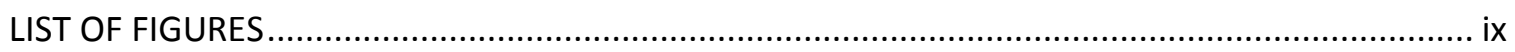

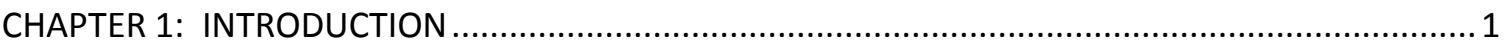

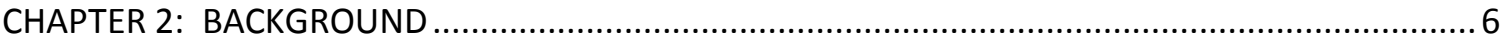

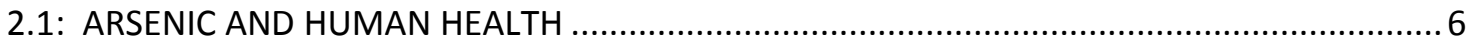

2.2: DEFAULT BACKGROUND CONCENTRATIONS AND RISK BASED ..................................... 6

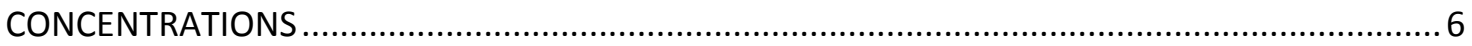

2.3: BACKGROUND STUDIES OF ARSENIC IN NORTHWEST OREGON SOILS ........................... 8

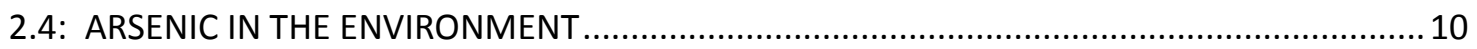

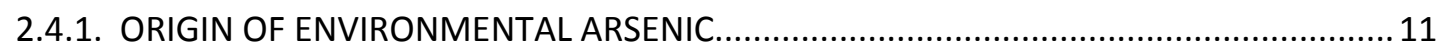

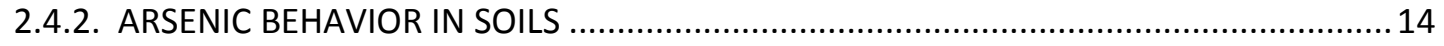

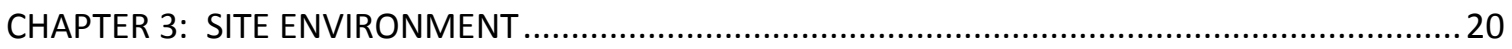

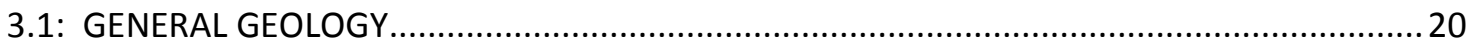

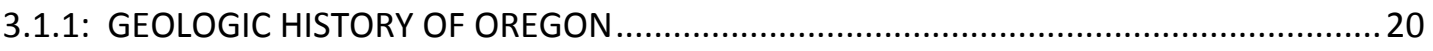

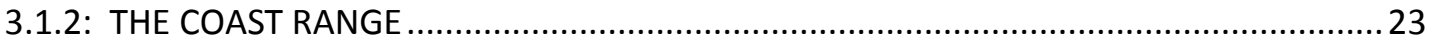

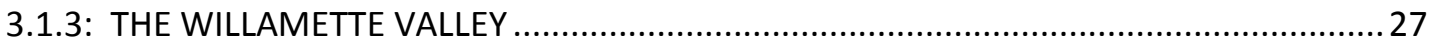

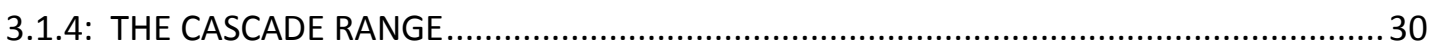

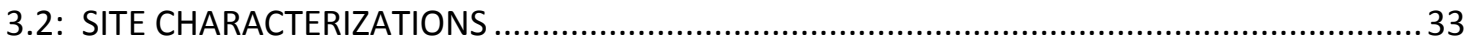

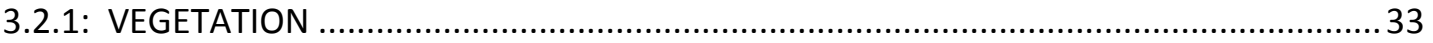

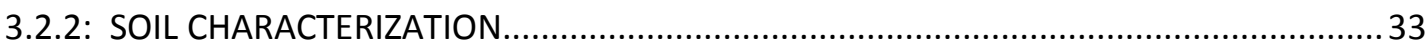

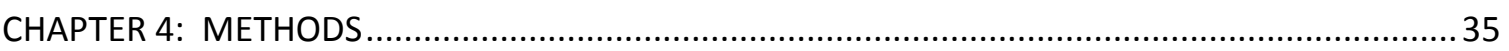

4.1: USING GEOGRAPHIC INFORMATION SYSYSTEMS (GIS) TO DETERMINE UNSAMPLED

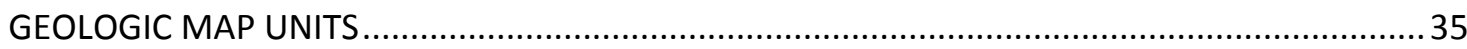

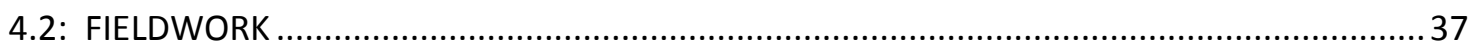

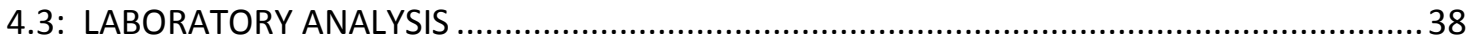

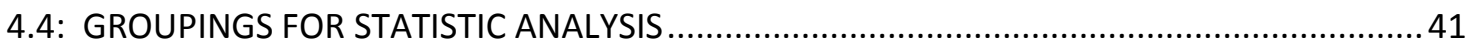




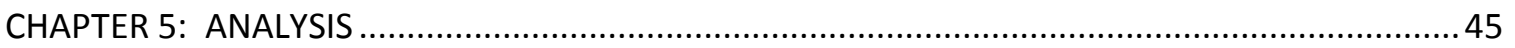

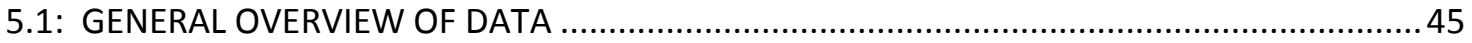

5.2: ANALYSIS OF VARIANCE AND MULTIPLE COMPARISON ANALYSIS ..................................... 48

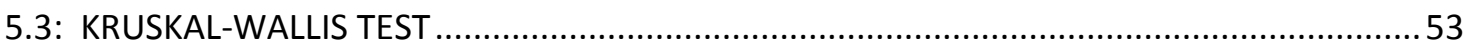

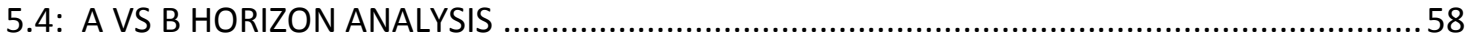

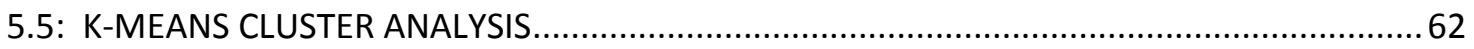

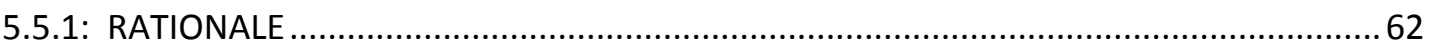

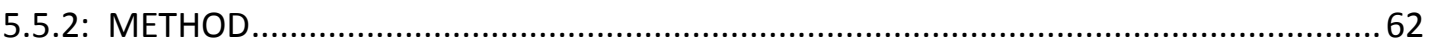

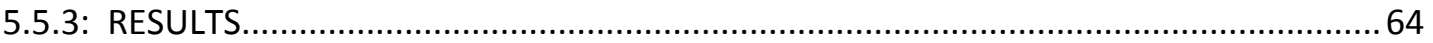

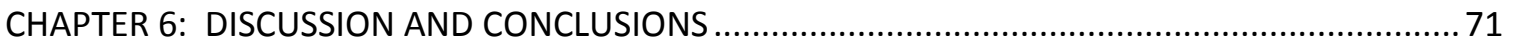

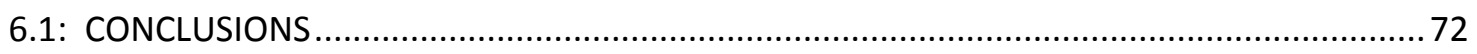

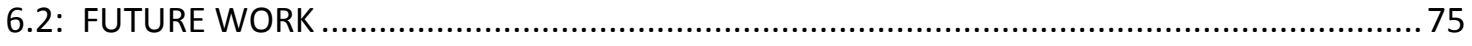

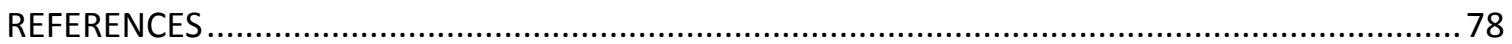

Appendix A: Overview U.S. and International Arsenic Cleanup Levels........................................ 89

Appendix B: Overview of Arsenic Content by Rock Type........................................................... 93

Appendix B: Dataset 1; From Tanaka (1988) ...................................................................... 93

Appendix B: Dataset 2; From Mandal and Suzuki (2001) .................................................. 96

Appendix C: Site Observations for Phase I (1995) Sites (Ashbaugh, 1995)..................................97

Appendix D: Description of Phase I Soil Samples (Ashbaugh, 1995) ......................................... 101

Appendix E: Site Observations for Phase II (2010) Sites .......................................................... 108

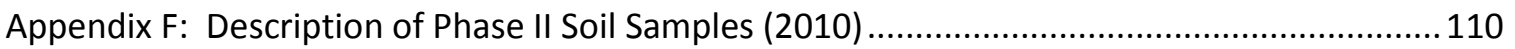

Appendix G: Site and Soil Pit Images from Sites Sampled During Phase II Sampling (2010) ...... 113

Appendix H: Example page from APEX Laboratory's Quality Control Sample Results Report ... 132

Appendix I: Descriptions of Lithology by Lithologic Group ...................................................... 133

Appendix I.1: Quaternary/ Tertiary Sediments and Sedimentary Rocks .............................. 133

Appendix I.2: Marine Sediments and Sedimentary Rocks ................................................ 135

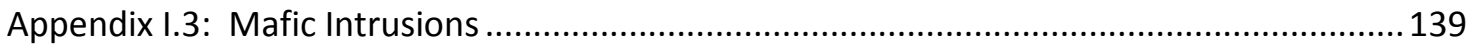

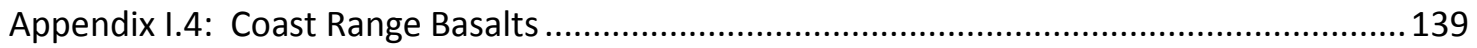

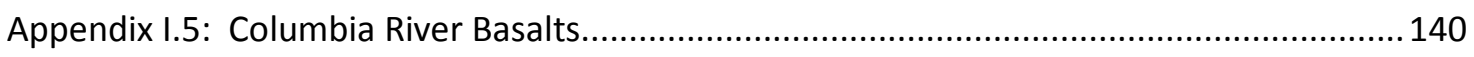

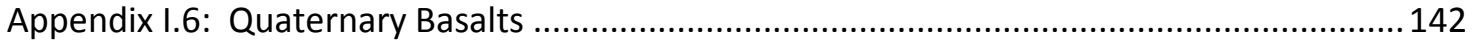

vi 
Appendix 1.7: Andesites .144

Appendix I.8: Rhododendron/Sardine Formations. 144

Appendix 1.9: Volcanic Sediments. 146

Appendix J: Soil Arsenic Data from Northwest Oregon ....................................................... 150

Appendix K: High and Low Values for Samples by Mapping Unit ............................................ 158

Appendix L: Outline Illustrating Outcomes of Stated Goals .................................................160 


\section{LIST OF TABLES}

Table 1: Oregon DEQ Risk Based Concentrations for Arsenic in Soils. .......................................... 8

Table 2: Measured arsenic values and basic statistics for pit TR6............................................. 41

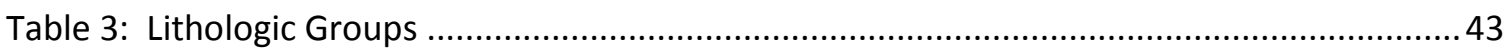

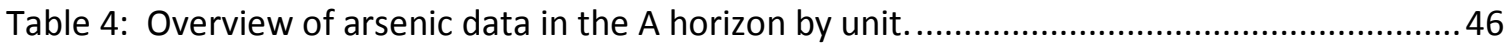

Table 5: Overview of arsenic data in the B horizon by unit.................................................... 46

Table 6: Overview of arsenic data in the A horizon by lithologic group ...................................... 47

Table 7: Overview of arsenic data in the B horizon by lithologic group. ..................................... 48

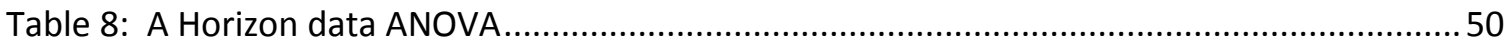

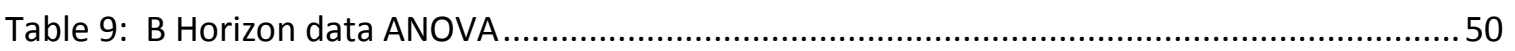

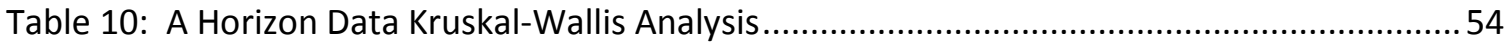

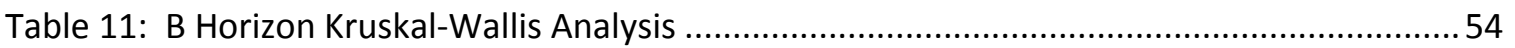

Table 12: Basic arsenic statistics of groups mapped based on analysis ........................................56

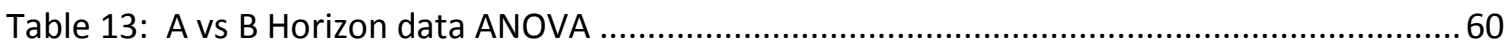

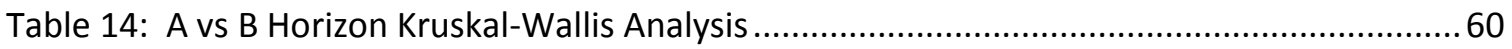




\section{LIST OF FIGURES}

Figure 1: The study area is defined by the Pacific Ocean in the west, the city of Eugene in the south, the city of Bend in the east, and the Columbia River in the north.

Figure 2: Goldberg (2002); Description verbatim: Arsenic adsorption on amorphous Fe oxide as a function of $\mathrm{pH}$ and As redox state: (a) arsenate; (b) arsenite.

Figure 3: Goldberg (2002); Description verbatim: Arsenic adsorption on amorphous Al oxide as a function of $\mathrm{pH}$ and As redox state: (a) arsenate; (b) arsenite.

Figure 4: Generalized Eh-pH diagram for arsenic in the presence of sulfur at $25 \mathrm{C}$ and $1 \mathrm{~atm}$ pressure. Assumes activity of $A s=10^{\wedge}-6$ and activity of $S=10^{\wedge}-3$. Note that the realgar mineral

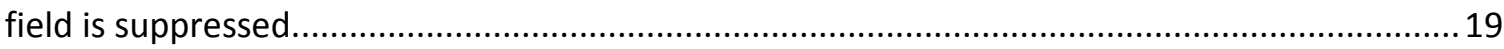

Figure 5: The physiographic provinces of northwest Oregon (NASA 2012) ............................... 21

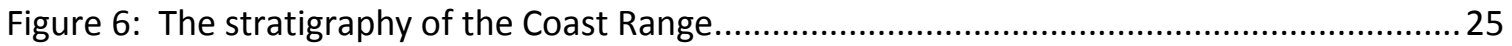

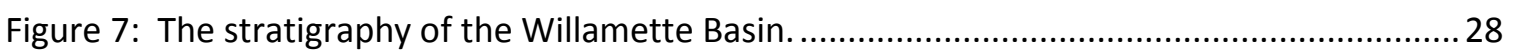

Figure 8: The Stratigraphy of the Cascade Mountain Range Province ......................................... 32

Figure 9: Location of sites sampled during Phase II (2010) fieldwork along with geologic unit associations. Unit labels and descriptions after Walker and MacLeod, 1991............................36

Figure 10: Geographic extent of lithologic groups and all site locations (Walker and MacLeod, 1991; Ashbaugh, 1995).

Figure 11: Stem-box plot showing mean, upper and lower quartile, data range, and outliers for the A horizon values of the five tested groups.

Figure 12: Stem-box plot showing mean, upper and lower quartile, data range, and outliers for the $B$ horizon values of the five tested groups.

Figure 13: Multiple comparison of A horizon arsenic concentrations finds that group MS is distinct from group $Q B$ in this horizon...

Figure 14: Multiple comparison of B horizon arsenic concentrations finds that group MS is distinct from all other tested groups in this horizon.

Figure 15: Multiple comparison test of A horizon data based on the Kruskal-Wallis analysis. This test shows the arsenic levels of group MS are statistically different from those of groups $Q B$ and QTS in the A horizon. The $X$ axis values represent the mean and standard deviation of the group's ranks....

Figure 16: Multiple comparison test of B horizon data based on the Kruskal-Wallis analysis. This test shows the arsenic levels of group MS are statistically different from those of groups QB, QTS and VS in the B horizon. The $\mathrm{X}$-axis values represent the mean and standard deviation of the group's ranks.

Figure 17: Map showing the distribution of Marine Sedimentary and Sedimentary Rocks group units and the other tested lithologic groups throughout the northwest Oregon study area. This map illustrates areas where soil arsenic content is statistically distinct (Walker and MacLeod, 1991). 
Figure 18: Stem-box plot showing mean, upper and lower quartile, data range, and outliers for $A$ and $B$ horizon data by lithologic group. X-Horizon labels indicate lithologic group and horizon. 59 Figure 19: The standard ANOVA multiple comparison test indicates that group $M S$ in the $A$ horizon is distinct from group QB in the $A$ and $B$ horizon. Group MS in the B horizon is distinct from all other tested groups.

Figure 20: The Kruskal-Wallis multiple comparison test indicates group MS in the A horizon is distinct from group $Q B$ in both the $A$ and $B$ horizon. Group $M S$ in the $B$ horizon is distinct from

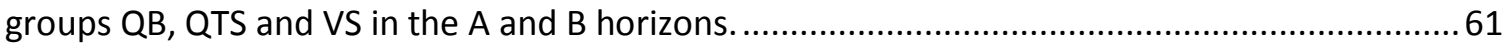

Figure 21: Scatterplot illustrating the results of the three group cluster analysis. ........................65

Figure 22: Silhouette graph illustrating the strength of the three cluster analysis results..........65

Figure 23: Scatterplot illustrating the results of the four group cluster analysis. .......................66

Figure 24: Silhouette graph illustrating the strength of the four cluster analysis results. ............66

Figure 25: Scatterplot illustrating the results of the five group cluster analysis. ........................67

Figure 26: Silhouette graph illustrating the strength of the five cluster analysis results............67

Figure 27: Bar graph connecting lithologic groups (X-axis) to the groups resulting from the three group cluster analysis (color symbology). Color symbology reflects clusters noted in Figure 21 and Figure 22.

Figure 28: Bar graph connecting lithologic groups (X-axis) to the groups resulting from the four group cluster analysis (color symbology). Color symbology reflects clusters noted in Figure 23 and Figure 24.

Figure 29: Bar graph connecting lithologic groups ( $X$-axis) to the groups resulting from the five group cluster analysis (color symbology). Color symbology reflects clusters noted in Figure 25 and Figure 26. 


\section{CHAPTER 1: INTRODUCTION}

This study aims to further characterize the natural background level of arsenic in northwest Oregon soils, establish statistical connections between the measured arsenic content of the soil and the underlying bedrock, and explore other data trends in soil arsenic values when possible. The study area lies between the Columbia River in the north and the city of Eugene in the south. The Pacific Ocean defines the western boundary of the study area, with the city of Bend defining the eastern boundary (Figure 1). Understanding naturally occurring arsenic in the soils of the northwest quadrant of the state is particularly important from a public health standpoint, as this area is home to the majority of the state's population.

Oregon, along with many other states and government entities, regulates exposure to anthropogenic arsenic in soils. These levels are regulated by individual studies using risk-based concentrations (RBC's) and a default background concentration of arsenic (Oregon DEQ, 2002; 2009; 2010). The determination of background concentration levels and risk-based concentrations, as well as the enforcement of cleanup requirements, is the responsibility of the Oregon Department of Environmental Quality (Oregon DEQ, 2009; 2010). Risk-based concentration levels are derived from equations combining exposure assumptions with toxicity data. Remediation is mandated for public health purposes to ensure that anthropogenic arsenic contamination is diminished or eliminated. 


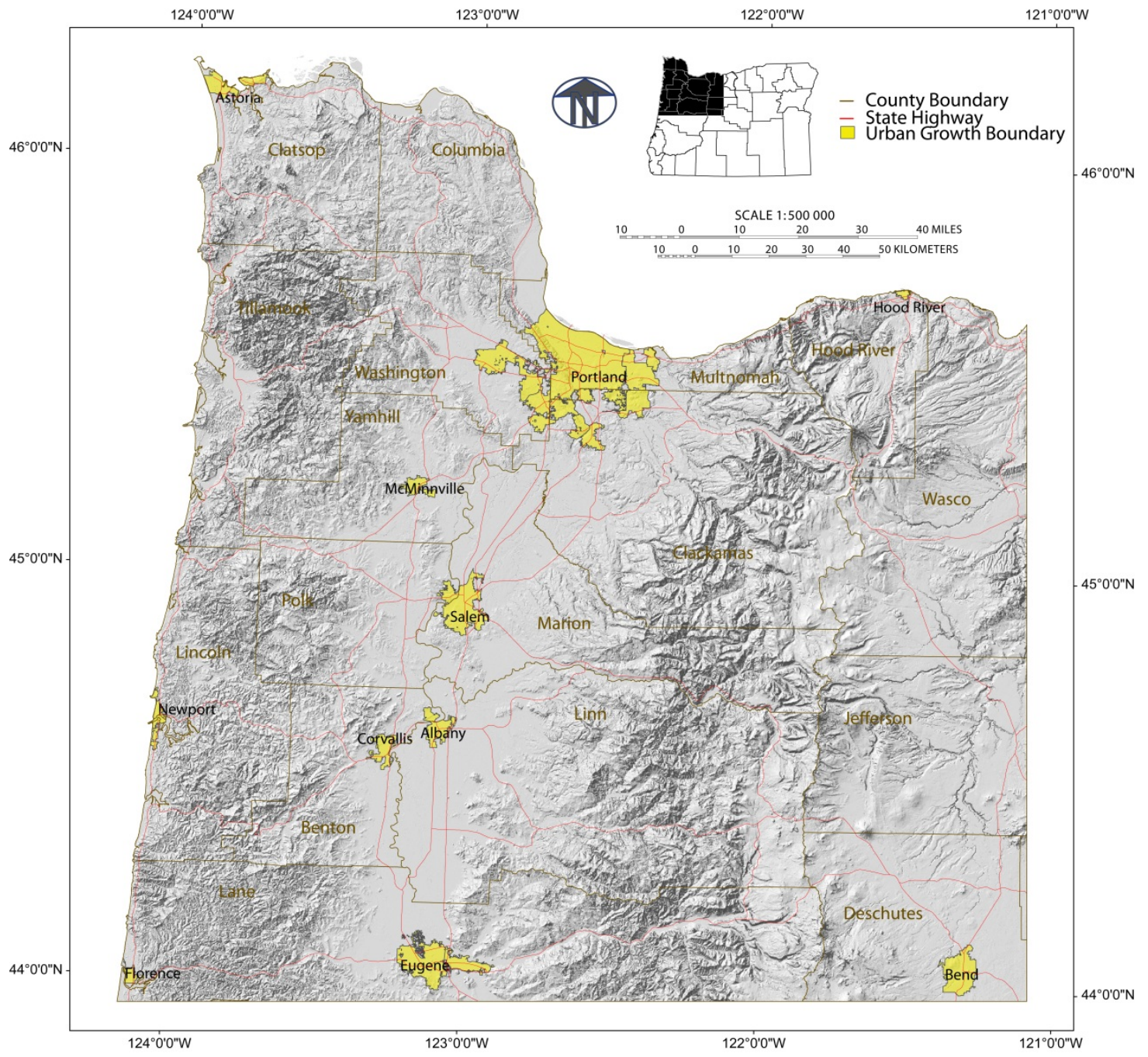

Figure 1: The study area is defined by the Pacific Ocean in the west, the city of Eugene in the south, the city of Bend in the east, and the Columbia River in the north. 
Oregon differentiates risk based concentrations of arsenic by exposure pathway (water, soil, etc.) and exposure environment (residential, occupational, etc.) These RBC's are under $2 \mathrm{ppm}$ for all circumstances excepting construction and excavation workers (Oregon DEQ, 2009). The default background concentration of arsenic in Oregon soils has been determined by the Oregon DEQ to be $7 \mathrm{mg} / \mathrm{kg}$ statewide (Oregon DEQ, 2002, 2010). This default background level is of primary interest to this study and is currently under evaluation and subject to change by the Oregon DEQ.

Three previous studies suggest that the amount of naturally occurring arsenic in the study area's soils may be higher than the $7 \mathrm{mg} / \mathrm{kg}$ default background level set by the Oregon DEQ (Ashbaugh, 1995; Boschmann, 2008; Ricker and Shepker, 2009; Oregon DEQ, 2002; 2010). Approximately $11 \%$ of soil samples collected for Ashbaugh's 1995 study and tested for arsenic by Boschmann (1998) had measurable levels of arsenic above the $20 \mathrm{ppm}$ detection limit of the available test (Ricker and Schepker, 2009). This analysis raised significant questions, as it suggested the values the Oregon DEQ use to evaluate sites for the remediation of soil arsenic may be too low (Oregon DEQ, 2002, 2010). Fully understanding the natural background level of soil arsenic is critical to determining if the cleanup protocols currently being used by the Oregon DEQ are reasonable and effective. Without accurately describing this background level, there is a risk of allowing too much anthropogenic arsenic in the environment, a significant health risk. A lack of understanding in this area also risks the cleanup requirements being too stringent, legally mandating that landowners remediate large amounts of naturally occurring arsenic and creating economic 
hardship. For these reasons, a balanced and reasonable policy based on good scientific information and analysis is required.

\section{AIMS AND OBJECTIVES:}

Goal: Add to the knowledge background soil arsenic content in the northwest Oregon study area. The following steps were taken to attain this goal:

1. Obtained soil samples from above as many major geologic formations within the study area as possible. Soils were sampled pedologically by sampling from the surface $A$ horizon and the underlying $B$ horizon. Previous studies suggest arsenic levels are likely higher in the B horizon in well-developed soils (Burns et al., 1991).

a. Samples collected for Ashbaugh's (1995) radionuclide study were tested for arsenic content (step 2).

b. Used a geographic information system (GIS) to determine major formations in the study area from which samples were not previously obtained by Ashbaugh (1995) (Walker and MacLeod, 1991). The eight units which covered the largest area within the study area were chosen for additional sampling.

c. Conducted additional field work to sample soils from above the formations identified through step $1 \mathrm{~b}$. Sampling procedures were modeled after those used by Ashbaugh (1995) for continuity. 
2. Determined the arsenic content of the sampled soils (step 1). A commercial laboratory (Apex Laboratories) tested the soil samples for arsenic content using Inductively Coupled Plasma Mass Spectrometry (ICPMS). Tests were run to Oregon DEQ and Environmental Protection Agency (EPA) Standards.

3. Produced a database of soil arsenic values including measured $A$ and $B$ horizon arsenic values in parts per million, location of sampling, and underlying geologic unit per Walker and MacLeod (1991).

4. Statistically analyzed the data for significant trends.

a. Statistically evaluate data to determine connections between the measured level of arsenic in soils above similar rock types

b. Statistically evaluate the data to determine connections between the measured arsenic level of soils in the A and B horizon.

5. Mapped the arsenic values using GIS in a scientifically appropriate manner based on the conducted statistical analysis. 


\section{CHAPTER 2: BACKGROUND}

\section{1: ARSENIC AND HUMAN HEALTH}

It is well documented that a variety of human health problems are linked to arsenic exposure. Health problems associated with arsenic exposure include vascular diseases such as blackfoot disease and high blood pressure (IPCS, 2001). Diabetes and forms of nerve damage have been linked to long term arsenic exposure (IPCS, 2001). Arsenic has also been linked to severe reproductive problems such as low birth weight, stillbirth, and birth defects (IPCS, 2001). Acute arsenic exposure has been known to result in death.

Arsenic is a known carcinogen. Although the exact method by which arsenic exposure causes cancer is not clearly known, Hughes (2002) discusses possible mechanisms. These include protein inhibition, promotion of tumor growth, and the deletion of genetic material resulting in mutations (Hughes, 2002). Arsenic may impede levels of oxygen in the body, diminishing a damaged cell's healing capability (Hughes, 2002). Arsenic is primarily connected to lung, bladder, kidney, and skin cancers (IPCS, 2001).

\section{2: DEFAULT BACKGROUND CONCENTRATIONS AND RISK BASED CONCENTRATIONS}

Due to the severe negative human health effects associated with arsenic exposure, many government institutions regulate arsenic exposure from soils and water. In the United States, these regulations are typically determined by the 
individual states. An overview of action levels for arsenic throughout the United States and internationally is compiled in Appendix A: Overview U.S. and International Arsenic Cleanup Levels. These levels are commonly determined by the exposure levels that are believed to cause significant health risks.

The United States Environmental Protection Agency (EPA) has set Regional Screening Levels (RSLs) (formerly referred to as Preliminary Remediation Goals, or PRG's). These are risk-based levels that combine what is known about how the contaminant interacts with the human body to what is known about the contaminant's toxicity (EPA, 2012). These values are used for prioritizing contaminated sites for cleanup, setting RBC's, identifying when a cleanup is required, and determining the desired level of cleanup at a contaminated site along with other determinations. (EPA, 2012). The RSL for residential soil is .39 mg/kg and is 1.6 $\mathrm{mg} / \mathrm{kg}$ for industrial soils (EPA, 2012).

In Oregon, the DEQ's Environmental Cleanup and Tanks program regulates environmental contaminants. The DEQ has published risk based concentrations (RBCs) for a variety of contaminants, including arsenic (Table 1). The DEQ distinguishes between arsenic content in soil and groundwater (Oregon DEQ, 2009). 
Table 1: Oregon DEQ Risk Based Concentrations for Arsenic in Soils.

These values are differentiated by the exposure pathway in which the arsenic is encountered: through skin contact, inhalation, or ingestion (Oregon DEQ, 2009).

\begin{tabular}{|c|c|}
\hline Receptor Scenario & $\begin{array}{c}\text { Soil Arsenic Content in Parts Per } \\
\text { Million (PPM) }\end{array}$ \\
\hline Residential & .39 \\
\hline Urban Residential & 1.0 \\
\hline Occupational & 1.7 \\
\hline Construction Worker & 13 \\
\hline Excavation Worker & 370 \\
\hline
\end{tabular}

The Oregon DEQ has set the default background value of arsenic in soils statewide at $7 \mathrm{mg} / \mathrm{kg}$ (Oregon DEQ, 2002, 2010). This value is of primary interest to this study. It is currently subject to change and has recently been under evaluation. Per the Oregon DEQ (2006), "Contaminants found above background levels are compared to [the EPA's RSLs] and DEQ's risk-based concentrations (RBCs) to evaluate whether these contaminants pose unacceptable risks to current or future site users, construction and/or excavation works, or surrounding properties." Because these risk-based values are compared with background levels to determine cleanup requirements, a full understanding of the background level is required.

\section{3: BACKGROUND STUDIES OF ARSENIC IN NORTHWEST OREGON SOILS}

This project builds upon the thesis of Stuart Ashbaugh (1995), a Portland State University student who worked under Dr. Scott Burns. Ashbaugh collected soil samples from as many different bedrock formations as possible, per the geologic map of Oregon, as part of a radionuclide study (Ashbaugh, 1995; Walker and 
MacLeod, 1991). Both A and B horizon samples were taken at each site. Sites were chosen in wooded areas that had no indication of significant anthropogenic contamination (Ashbaugh, 1995). The arsenic values resulting from these samples are therefore expected to reflect the background arsenic content of these soils.

Darek Boschmann (2008), also a Portland State University student, tested 170 of the samples collected by Ashbaugh (1995) for arsenic content. The analytical test method used in Boschmann's study detected soil arsenic levels above 20 ppm. Nineteen of the 170 samples (11\%) measured arsenic above the 20 ppm minimum detection limit. These 19 samples were collected at 13 sites and measured arsenic between 21.2 and 167 ppm. Seven of the 19 samples were B horizon soils, with the remaining 12 samples being A horizon samples. The samples tested for Boschmann's (2008) study were retested for arsenic content as part of this study, and these new values were used in favor of the values tested by Boschmann (2008). Nonetheless, Boschmann's (2008) work is critical to the inception of this project. The number of samples in Boschmann's (2008) study containing arsenic above the 20 ppm detection limit of the test used raised significant questions about the level of background arsenic in the soils within this project's study area.

Ricker and Shepker (2009) reevaluated the arsenic data generated by Boschmann (2008) from the samples collected by Ashbaugh (1995). The 2009 study by Ricker and Shepker was conducted as part of a graduate level Environmental Geology course taught by Dr. Burns and utilized a significant Geographic Information Systems (GIS) component. The study's primary premise, based on background 
literature, was that the level of naturally occurring arsenic in a soil is closely related to the lithology of underlying bedrock (Yan-Chu, 1994; Naidu and Bhattacharya, 2006). Based on this knowledge, a map was made highlighting geologic units whose overlying soils tested above $20 \mathrm{ppm}$ arsenic. This was done making the underlying assumption that additional soils in these areas would have similarly high levels of arsenic. In doing this, Ricker and Schepker determined areas within Oregon that were at risk for having naturally occurring soil arsenic levels in excess of $20 \mathrm{ppm}$. The Ricker and Schepker (2009) study found that the bedrock underneath the samples that contained arsenic in excess of $20 \mathrm{ppm}$ covered $35 \%$ of Oregon's total area.

\section{4: ARSENIC IN THE ENVIRONMENT}

To understand the levels of arsenic found in the soils tested for this study, it is necessary to understand how arsenic functions in the natural environment. This understanding requires ascertaining the original source of natural arsenic in soils. Natural arsenic content of soils is believed to be linked to the arsenic content of underlying bedrock, therefore the arsenic content of bedrock is discussed in detail (Yan-Chu, 1994; Naidu and Bhattacharya, 2006). How arsenic behaves once it is in the soil is also relevant and is therefore discussed here. 


\subsubsection{ORIGIN OF ENVIRONMENTAL ARSENIC}

\subsubsection{SOURCE OF ARSENIC AND ASSOCIATED MINERALOGY}

Arsenic content of rocks is closely connected to mineralogy. Arsenic is primarily linked with sulfide minerals and iron oxides, and rocks that contain these minerals in significant quantities generally contain the largest amounts of arsenic (Boyle and Jonasson, 1973). The correlation between iron and arsenic suggests that the highest amounts of soil arsenic are typically found in the reddest soils. These are usually B horizon soils where elements such as iron and arsenic have collected over time through leaching processes due to moisture and weathering processes (Birkeland, 1999; Burns et al., 1991). Some studies, particularly in the Bengal Basin of India, suggest a correlation between the weathering of micas and high arsenic levels (Dowling et al., 2002). Realgar (AsS), orpiment $\left(\mathrm{As}_{2} \mathrm{~S}_{3}\right)$ and arsenopyrite (FeAsS) are three common examples of arsenic bearing sulfides (Manning and Goldberg, 1997). Arsenopyrite is a particularly well known example and constitutes the primary arsenic bearing mineral found in the environment (Boyle and Jonasson, 1973; Francesconi and Kuehnelt, 2002).

\subsubsection{ARSENIC CONTENT OF ROCKS}

Arsenic content of rocks can be generalized in terms of lithology (Onishi and Sandell, 1955; Boyle and Jonasson, 1973; Tanaka, 1988). Although there is some variability in the arsenic content found in different types of igneous lithologies, these values are typically very close to each other and tend to be comparatively low (Onishi 
and Sandell, 1955; Boyle and Johnasson, 1973). Sedimentary rocks tend to have higher arsenic levels compared to igneous rocks (Tanaka, 1988). Some sedimentary processes allow for increased arsenic content, and some minerals that are conducive to high arsenic content are found primarily in sedimentary rocks (Boyle and Jonasson, 1973; Tanaka, 1988). Data on arsenic content in metamorphic rocks suggests that arsenic content in the daughter rock is correlated with the arsenic content of the parent rock (Tanaka, 1988). In some cases, metamorphic processes are believed to decrease the amount of arsenic in the rock (Onishi, 1970). The decrease of arsenic during the metamorphism of slates and graywackes is one example, as well as the leaching of arsenic out of sedimentary rocks that contain hematite (Onishi, 1970).

Data published in Onishi and Sandell (1955), Boyle and Jonasson (1973), and Tanaka (1988) connecting lithology to arsenic content is reprinted verbatim in Appendix B: Overview of Arsenic Content by Rock. The presentation of this table is based on Tanaka (1988) because it is a synthesis of data from both previous works. This presentation also includes the number of samples, average arsenic content and range of each group (Tanaka, 1988). More recent data published by Mandal and Suzuki (2002) is also presented (Appendix B: Overview of Arsenic Content by Rock). These data are presented as ranges of arsenic content and do not include averages (Mandal and Suzuki, 2002). Because more detailed information about the groups is unavailable, these data are included as additional information only and are not used further in this discussion. 
The presented data on arsenic in igneous rocks are differentiated by composition and texture (Tanaka, 1988; Appendix B: Overview of Arsenic Content by Rock). These data support the assertion that the arsenic content of igneous rocks is fairly similar when these data are grouped by composition and texture (Appendix B: Overview of Arsenic Content by Rock). The average arsenic content of each group of igneous rock samples is relatively low. The highest of these averages is $4.3 \mathrm{mg} / \mathrm{kg}$, with many of the averages in the 1 to $2 \mathrm{mg} / \mathrm{kg}$ range. The extrusive rocks of each composition have a higher average arsenic content than their intrusive counterparts, with the exception of Onishi and Sandell's (1955) mafic data. Here, both the intrusive and extrusive rock samples have the same average arsenic content (Onishi and Sandell, 1955; Appendix B: Overview of Arsenic Content by Rock).

The data on sedimentary rocks and arsenic content support that sedimentary rocks have generally higher average amounts of arsenic than igneous and metamorphic rocks (Appendix B: Overview of Arsenic Content by Rock). The average arsenic content for these groups ranges between and $2.3 \mathrm{mg} / \mathrm{kg}$ (Onishi and Sandell's 1955 clastic rocks group) and $33.7 \mathrm{mg} / \mathrm{kg}$ (Boyle and Jonasson's 1973 ocean sediments group)(Appendix B: Overview of Arsenic Content by Rock). Relatively high levels of arsenic tested in the recent sedimentary rock groups, iron-bearing rock group, and phosphates are unsurprising based on the correlation between arsenic and oxide and phosphate minerals (Boyle and Jonasson, 1973).

The metamorphic rock data describe the arsenic levels of these rocks differentiated by mode of metamorphism (Appendix B: Overview of Arsenic Content 
by Rock). These data do not support large decreases of arsenic in metamorphic rocks, and in fact, many metamorphic rocks tested contain significant amounts of arsenic (Appendix B: Overview of Arsenic Content by Rock). The lowest average value of arsenic in metamorphic rocks, $1.1 \mathrm{mg} / \mathrm{kg}$ for the schists tested by Boyle and Jonasson (1973), is similar to the low arsenic averages of igneous rock groups. Boyle and Jonasson (1973) tested the highest average arsenic content for metamorphic rocks; their slate and phyllite group averages $18.1 \mathrm{mg} / \mathrm{kg}$ arsenic (Appendix B: Overview of Arsenic Content by Rock).

\subsubsection{ARSENIC BEHAVIOR IN SOILS}

Once arsenic enters the soil environment, it takes one of four paths (McLaren et al., 2006): 1) Arsenic is leached into groundwater from both bedrock and soils. 2) Arsenic is taken in by plants as they intake water. 3) Arsenic can be removed from soils through other biological processes besides plant uptake. When this happens, the arsenic is typically volatized into the atmosphere. 4) Arsenic can also be adsorbed into the soil. It is this final pathway that is of particular interest in this study.

Arsenic in the soil environment is typically found in one of two oxidation states. Trivalent arsenite (AsIII), and pentavalent arsenate (AsV), are known to behave differently in soils depending on environmental factors. The oxidation state of arsenic found in soils is largely determined by the redox state of the soil 
environment (Manning and Goldberg, 1997). In oxidizing conditions, arsenate is prevalent primarily as $\mathrm{H}_{2} \mathrm{AsO}_{4}{ }^{-}, \mathrm{HAsO}_{4}{ }^{2-}$, or $\mathrm{AsO}_{4}{ }^{3-}$ (Sadiq, 1995; Manning and Goldberg, 1997; Mandal and Suzuki, 2002). In reducing conditions, arsenite is prevalent in the form of $\mathrm{H}_{3} \mathrm{AsO}_{3}{ }^{0}, \mathrm{H}_{2} \mathrm{AsO}_{3}{ }^{-}$or $\mathrm{HAsO}_{3}{ }^{2-}$ (Manning and Goldberg, 1997; Mandal and Suzuki, 2002). A common chemical reaction by which arsenic acid (an oxidizing agent) is reduced to arsenous acid is:

$$
\mathrm{H}_{3} \mathrm{As}^{\mathrm{V}} \mathrm{O}_{4}+2 \mathrm{H}^{+}+2 \mathrm{e}^{-} \leftrightarrow \mathrm{H}_{3} \mathrm{As}^{\prime \prime \prime} \mathrm{O}_{3}+\mathrm{H}_{2} \mathrm{O}
$$

(Naidu and Bhattacharya, 2006)

Arsenite is known to be more mobile through the soil environment than arsenate, as well as more toxic to human health (Mandal and Suzuki, 2002; Naudu and Bhattcharya, 2006). At pH levels common in natural waters, arsenite tends to exhibit a neutral charge, while arsenate exhibits a negative charge (Manning and Goldberg, 1997). This difference in surface charge at common environmental pH's is believed responsible for arsenite's mobility and toxicity. Because of its lack of charge, arsenite adsorbs less readily onto soils as compared to arsenate and is therefore more mobile and more toxic (Manning and Goldberg, 1997).

Arsenic amounts measured in soils are heavily dependent on how much arsenic attaches, or adsorbs, onto soil particles. Smith et al. (1999) studied the adsorption of arsenic into soils and found that, at various $\mathrm{pH}$ levels, more arsenate was generally adsorbed into soils than arsenite. Iron oxides are a primary class of minerals that readily adsorb both forms of arsenic (Smith et al., 1999). Aluminum hydroxide and phyllosilicates are known to encourage adsorption of arsenite 
(Manning and Goldberg, 1997; Smith et al., 1999; Smith and Naidu, 2002). Other minerals that encourage adsorption of arsenic include manganese, alluminosillicates, phosphates, and ferrihydrite (Smith et al., 2002). The oxidation state of the arsenic, the $\mathrm{pH}$ of the soil environment, and the minerals available for the arsenic to adsorb onto are all factors which influence how much arsenic will adsorb into the soil. Arsenic adsorption onto iron oxides and aluminum oxides was studied by Goldberg (2002) and exhibit how the factors of $\mathrm{pH}$, mineralogy and arsenic's oxidation state play a role in the adsorption of arsenic.

The adsorption of arsenite and arsenate onto iron oxides as illustrated by Goldberg (2002) is shown as Figure 2. Goldberg's (2002) study illustrates how in the presence of iron oxides, the amount of arsenate adsorbing onto iron oxides in the acidic and neutral environment is relatively stable. At approximately $\mathrm{pH} 8$, significant amounts of the arsenate begin to desorb from the iron oxide. The amount of arsenite adsorbed onto the iron oxide does slightly increase with increasing $\mathrm{pH}$, but overall, changes very little as $\mathrm{pH}$ changes according to this study. 


\section{Adsorption on Amorphous Iron Oxide}

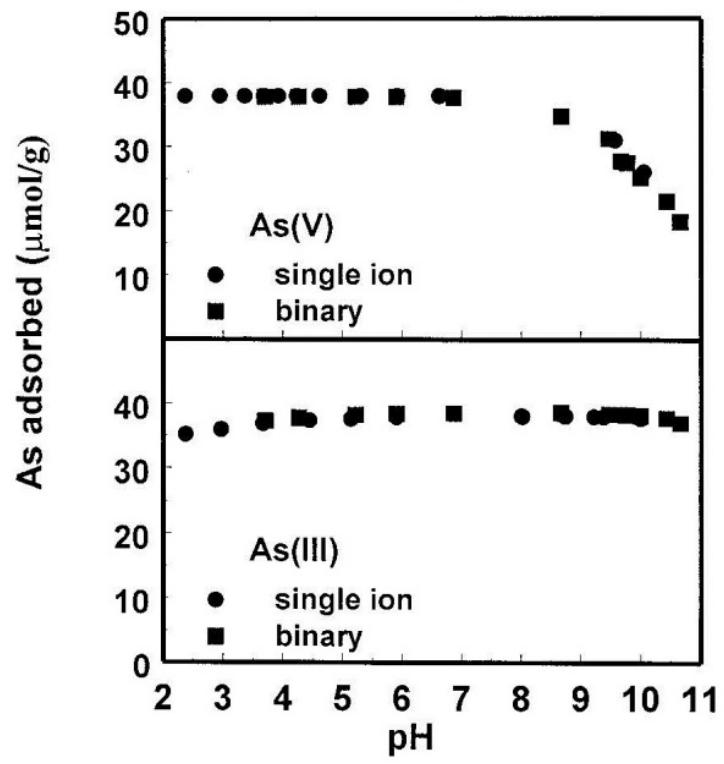

Figure 2: Goldberg (2002); Description verbatim: Arsenic adsorption on amorphous Fe oxide as a function of $\mathrm{pH}$ and As redox state: (a) arsenate; (b) arsenite.

Single ion systems: $A s_{T}=20 \mu \mathrm{M}$. Binary systems: $A s(I I I)_{T}=A s(V) T=20 \mu M$. Suspension density: $0.5 \mathrm{~g} \mathrm{~L}^{-1}$.

The result of Goldberg's (2002) study of arsenic adsorption onto aluminum oxides is shown as Figure 3. Similar to arsenic adsorption onto iron oxides, the amount of arsenate adsorbed onto aluminum oxides drops off when the $\mathrm{pH}$ of the environment becomes basic. In this case, this drop in amount of adsorbed arsenate begins at a pH of approximately 9.5 and continues as $\mathrm{pH}$ rises. Unlike the adsorption of arsenite onto iron oxides, the adsorption of arsenite onto aluminum oxides was found to vary significantly with pH (Goldberg, 2002). Goldberg's (2002) results show very low amounts of arsenite adsorbing onto the aluminum oxide when the environment is acidic ( $\mathrm{pH} 4$ and below). The amount of arsenite adsorbing onto the aluminum oxide begins to rise at this $\mathrm{pH}$ and peaks at approximately $\mathrm{pH} 8 . \mathrm{A}$ 
significant decrease in the amount of arsenic adsorbed onto the aluminum oxide is noted from this point as $\mathrm{pH}$ continues to rise.

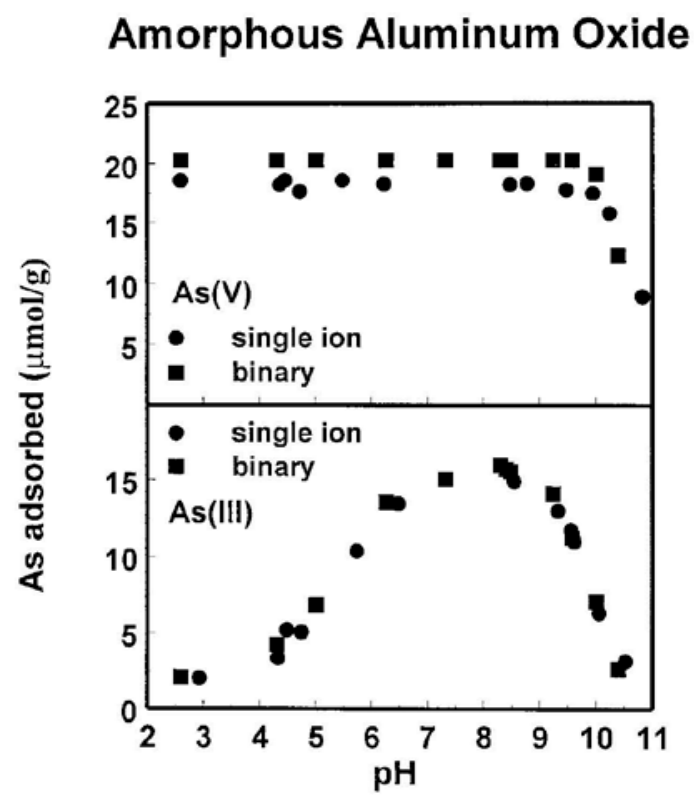

Figure 3: Goldberg (2002); Description verbatim: Arsenic adsorption on amorphous Al oxide as a function of $\mathrm{pH}$ and As redox state: (a) arsenate; (b) arsenite.

Single ion systems: $A s_{T}=20 \mu \mathrm{M}$. Binary systems: $A s(I I)_{T}=A s(V) T=20 \mu \mathrm{M}$. Suspension density: $0.5 \mathrm{~g} \mathrm{~L}^{-1}$.

In addition to $\mathrm{pH}$ playing a role in arsenic adsorption, the oxidation/reduction state of the environment plays a role in how arsenic functions in the natural environment. As previously stated, the REDOX state of the environment primarily affects the oxidation state of the arsenic present. An Eh-pH diagram depicting stable forms of arsenic in the presence of sulfur as $\mathrm{pH}$ (x-axis) and oxidation potential (Eh) (y-axis) change is shown as Figure 4. For oxidation potential values, positive values indicate an oxidizing environment, with negative numbers representing a reducing 
environment (Krauskopf and Bird, 1995; Misra, 2012). Figure 4 illustrates how these two factors of oxidation potential and $\mathrm{pH}$ together affect which arsenic compounds are found in the natural environment.

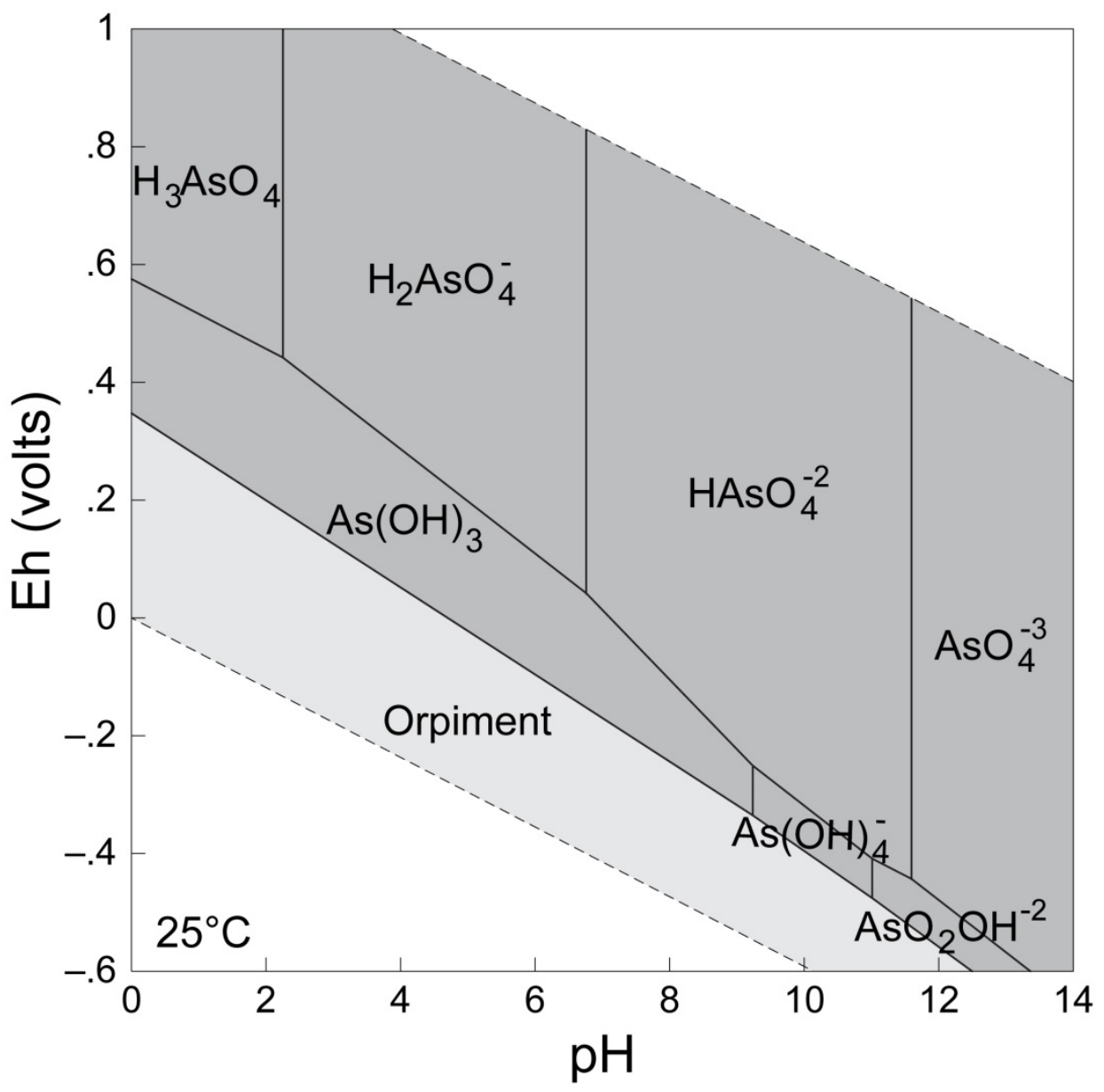

Figure 4: Generalized Eh-pH diagram for arsenic in the presence of sulfur at 25C and $1 \mathrm{~atm}$ pressure. Assumes activity of $A s=10^{\wedge}-6$ and activity of $S=10^{\wedge}-3$. Note that the realgar mineral field is suppressed. 


\section{CHAPTER 3: SITE ENVIRONMENT}

\section{1: GENERAL GEOLOGY}

The geologic history of the study area as reported here relies heavily on Orr and Orr's (1999) work. Unless otherwise noted, the following text was liberally extracted from their work. In this section, the general tectonic history of the project's study area is discussed, followed by a description of the geology found in each of the three physiographic provinces in the study area (Figure 5). Detailed descriptions of the major geologic units in the study area are included in Appendix I: Descriptions of Lithology by Lithologic Group.

The study area ranges from $43.95^{\circ}$ through $46.25^{\circ}$ north latitude and $124.15^{\circ}$ through $121.1^{\circ}$ west longitude (Figure 1). The study area covers three physiographic provinces in Oregon, the Coast Range, the Willamette Valley, and the Cascade Mountains (Figure 5). The climate of the study area is defined by proximity to the Pacific Ocean (Ashbaugh, 1995). Winters throughout the study area are primarily cool and wet, while summers are short, dry and warm.

\subsection{1: GEOLOGIC HISTORY OF OREGON}

The geology of the study area is heavily characterized by volcanic events beginning in the early Eocene (approximately $44 \mathrm{Ma}$ ) (Orr and Orr, 1999). The subduction of the offshore Farallon Plate underneath the North American Plate is responsible for the onset of this significant period of volcanism (Orr and Orr, 1999). 


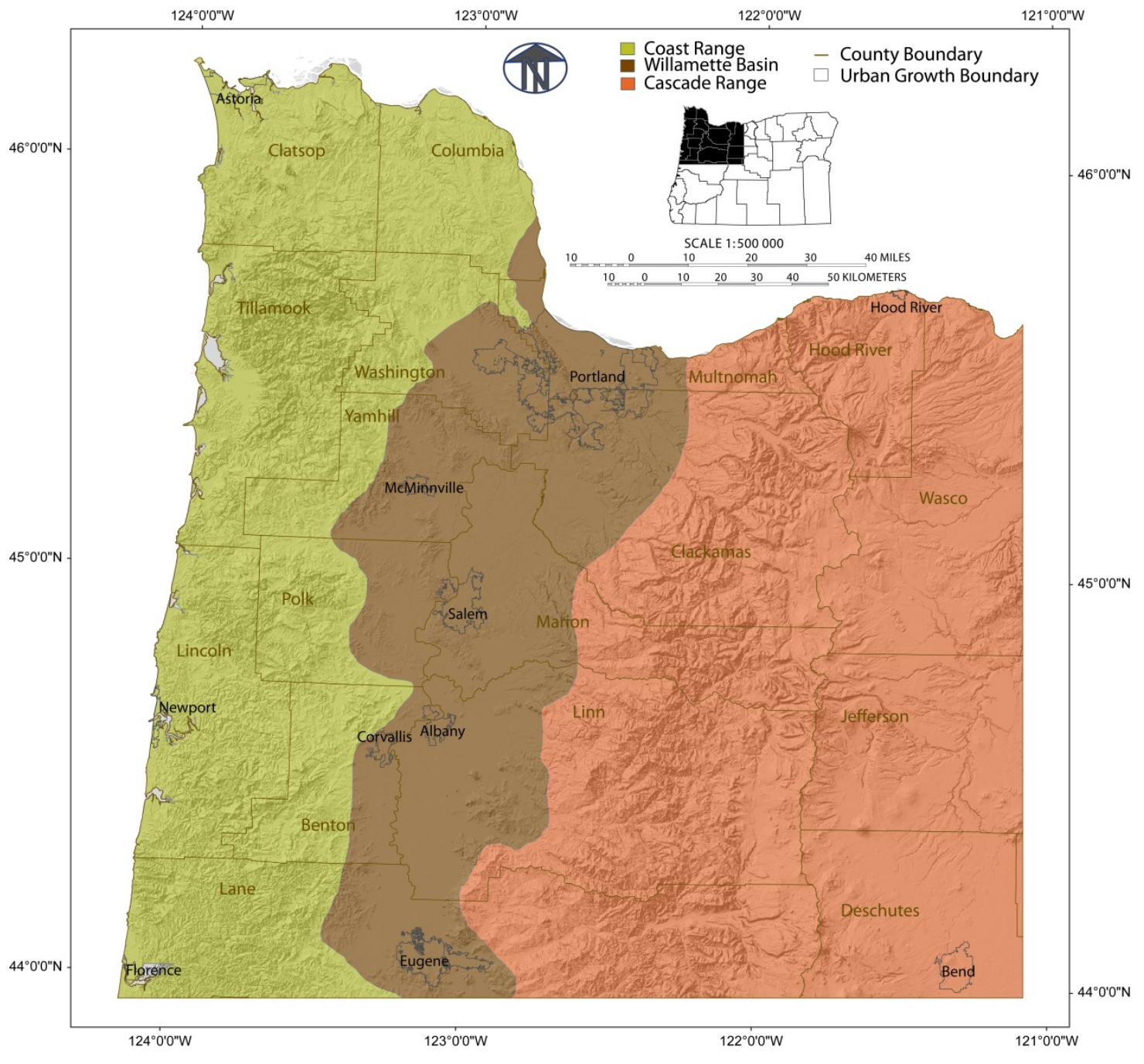

Figure 5: The physiographic provinces of northwest Oregon (NASA 2012) 
As evidenced by an unconformity between 38 and $35 \mathrm{Ma}$, this Cascade volcanism stopped at this time and subsidence occurred in the study area (Orr and Orr, 1999). This subsidence allowed for the creation of offshore basins just off the coast approximately $37 \mathrm{Ma}$. These basins are associated with the deposition of basalts, basaltic sandstones and conglomerates (Orr and Orr, 1999).

A long period of volcanism began at approximately $35 \mathrm{Ma}$ and continued through the early Miocene until approximately $20 \mathrm{Ma}$ (Orr and Orr, 1999). Eruption of silicic volcanics, including ash flows, tuffs, and lavas, was common throughout the study area during this period. Deposition of felsic siltstones and sandstones is also noted during this period (Wells et al., 1983; Orr and Orr, 1999). felsic siltstones and sandstones (Orr and Orr, 1999).

Between 16.5 and $9 \mathrm{Ma}$, regional uplift throughout the study area occurred and coincided with the eruption of the Columbia River basalt flows throughout northeastern Oregon, eastern Washington, and western Idaho (Orr and Orr, 1999). These basalts cover a significant portion of the study area (Orr and Orr, 1999).

In the last 4.6 Ma, the study area has seen periods of volcanism and glaciation. Extensional tectonics and faulting are associated with this volcanism (Orr and Orr, 1999). The Willamette Basin was covered by Missoula Flood sediments between 18,000-15,000 calendar years B.P. (Allen et al., 2009). 


\subsection{2: THE COAST RANGE}

\subsubsection{1: COAST RANGE GEOGRAPHY}

The Coast Range Province extends from the Pacific Ocean through approximately $123.2^{\circ}$ west longitude (Figure 5). The Coast Range also includes the offshore continental shelf, continental slope, and offshore subduction zone (Orr and Orr, 1999). The Coast Range province is characterized by a series of coastal mountains with a maximum elevation just over 1000 meters in the east and typical coastal features such as dune fields, estuaries, sand spits and bays in the west (Orr and Orr, 1999).

Because the climate is heavily influenced by the Pacific Ocean, this province is known to have the most temperate climate in Oregon including the warmest average winter temperatures, the coolest average summer temperatures, and the largest rainfall values in the state (Orr and Orr, 1999).

\subsubsection{2: COAST RANGE GEOLOGY}

The stratigraphy of the Coast Range province, as illustrated by Orr and Orr (1999) is reprinted here as Figure 6. This stratigraphic column is drawn for three Coast Range areas: Coos Bay, the Central Coast Range, and Columbia County. The Columbia County column is referred to as the northern Coast Range for this discussion. The Central Coast Range and Columbia County portions of this 
stratigraphic column are of interest to this study and should be consulted for this discussion.

Marine volcanics and marine sedimentary rocks were deposited in the central and northern Coast Range province throughout the Eocene. The oldest volcanic rocks in the central and northern Coast Range stratigraphy are the lower Eocene Siletz River Volcanics (Figure 6). This volcanism is the result of the Farallon plate subducting under the North American plate (Orr and Orr, 1999). The pillow structures found in these basalts are indicative of eruption in a marine environment (Walker and MacLeod, 1991).

The overlying Eocene marine stratigraphic sequence in the central Coast Range continues with the Yamhill, Nestucca, and Yachats formations. Marine silts and muds characterize the Yamhill Formation (Orr and Orr, 1999). The Nestucca Formation, composed of mud, sand, and siltstones, indicates a deeper ocean environment in the late Eocene central Coast Range (Orr and Orr, 1999). The Nestucca Formation muds are interspersed with the marine Yachats basalts (Orr and Orr, 1999). The Eocene marine environment evident in the Central Coast Range predictably dominates the northern Coast Range Eocene stratigraphic sequence as well. The Cowlitz Formation, shallow sea conglomerates, sands and shales, are evidence of this marine environment (Orr and Orr, 1999). 


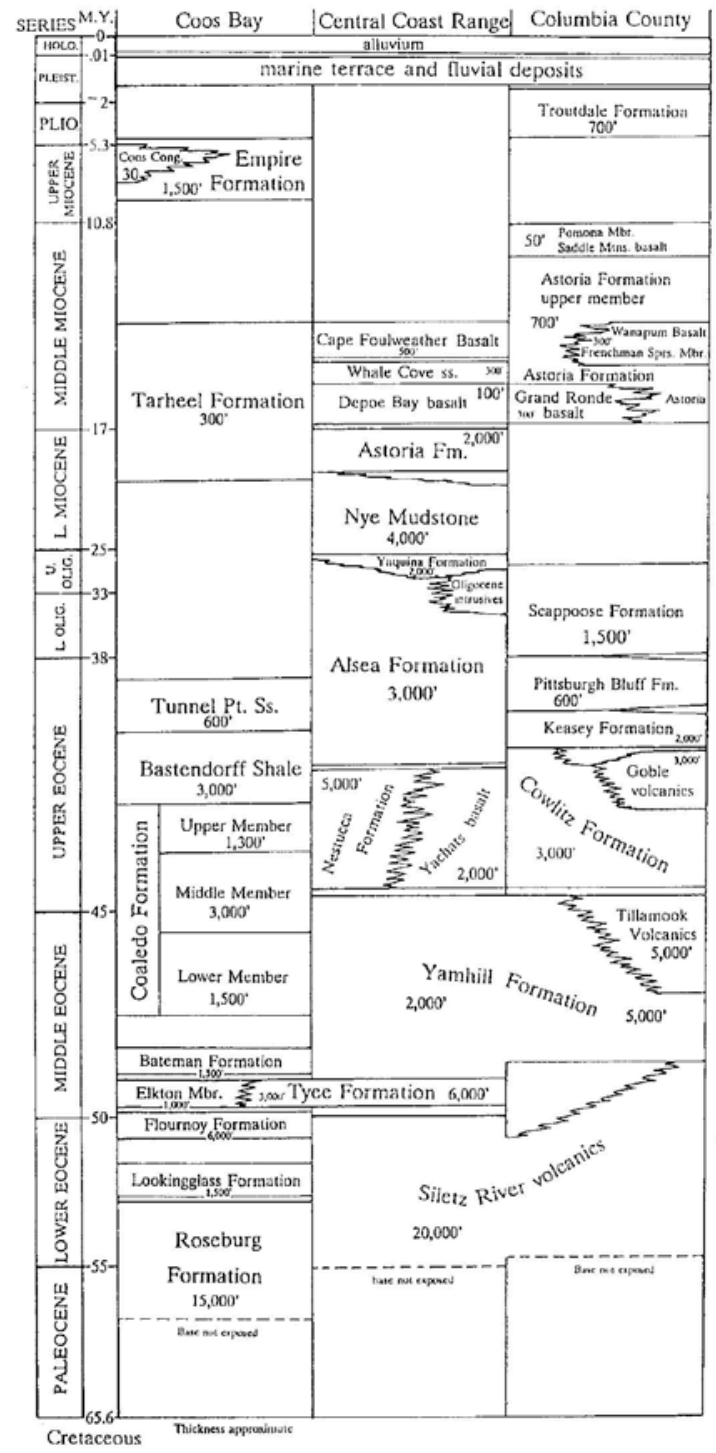

Figure 6: The stratigraphy of the Coast Range. After Orr and Orr, 1999

As the Eocene ended and Oligocene commenced, a marine environment continued to predominate in both the central and northern Coast Range. In the central Coast Range, this time period is characterized by the deposition of the Alsea and Yaquina formations (Orr and Orr, 1999). Both of these formations are composed of marine silts and sands with layers of volcanic ash (Orr and Orr, 1999). 
During the Oligocene, the northern Coast Range stratigraphic column also indicates a marine environment. The Pittsburg Bluff Formation tuffaceous sands and the arkosic Scappoose Formation deposited during this period are both shallow sea formations (Orr and Orr, 1999). The sediments comprising the Scappoose Formation have been linked to the eroding Idaho batholith by the presence of white mica (Orr and Orr, 1999).

The lower Miocene Nye mudstones of the central Coast Range are comprised of silt and mud and contain microfossils characteristic of the marine environment (Orr and Orr, 1999). The subsequent deposition of the Astoria Formation, composed primarily of sandstones and siltstones, is seen in the upper Miocene in the Central Coast Range and the middle Miocene in the northern Coast Range (Orr and Orr, 1999). The Astoria Formation is known for containing fossils characteristic of the marine environment, including mollusks, corals and brachiopods (Orr and Orr, 1999).

During the middle Miocene, the Columbia River basalts, one of the largest lava flows seen on Earth, engulfed the central Coast Range. These lava flows include the Depoe Bay Basalts, Cape Foulweather Basalts, and Grande Ronde Basalts as show in Figure 6 (Orr and Orr, 1999).

In the northern Coast Range, the Pliocene includes the deposition of thick Troutdale Formation gravels (Orr and Orr, 1999). This formation is indicative of a terrestrial environment, and these sediments were deposited when the Columbia River and other nearby rivers moved significant amounts of gravel into the Portland area (Trimble, 1963). 


\subsection{3: THE WILLAMETTE VALLEY}

\subsubsection{1: WILLAMETTE VALLEY GEOGRAPHY}

The Willamette Valley is a structural trough that has been and is still being altered by erosion and sedimentation. The valley trends from north to south and extends from approximately $123.2^{\circ}$ through $122.6^{\circ}$ west longitude. It is approximately $160 \mathrm{~km}$ long and $60 \mathrm{~km}$ wide (Orr and Orr, 1999). The southern end of the valley lies at approximately 122 meters above sea level (Orr and Orr, 1999). The elevation of the basin steadily decreases northward, and the Portland area lies at sea level (Orr and Orr, 1999). Oregon's largest cities, Portland and Salem, and 70 percent of the state's population reside in this province (Orr and Orr, 1999).

Low rolling hills and alluvial flats are characteristic of this province (Orr and Orr, 1999). The northern part of the valley is hilly, with the Eola, Ankeny, and Waldo hills in the Salem area and the Tualatin and Chehalem Mountains in the Portland area (Orr and Orr, 1999). The Willamette River flows north throughout the length of the valley to its confluence with the Columbia River. The Clackamas, Sandy, and Tualatin rivers are major tributaries of the Willamette River.

\subsubsection{2: WILLAMETTE VALLEY GEOLOGY}

Figure 7 illustrates the stratigraphy of the Willamette Valley per Orr and Orr (1999) and should be consulted for the discussion below. The stratigraphy of the valley is illustrated at three places: in Eugene (the southern Willamette Valley), 
Sheridan and McMinnville (the central Willamette Valley), and Oregon City and Molalla (the northern Willamette Valley).

In the Willamette Valley, as in the Coast Range, the earliest rocks noted are the Siletz River Volcanics (Orr and Orr, 1999). Some Eocene marine environment formations noted in the Coast Range Province are also seen in the Willamette Valley. These include the middle Eocene Yamhill and late Eocene Nestucca formations in the central portion of the Willamette Valley.

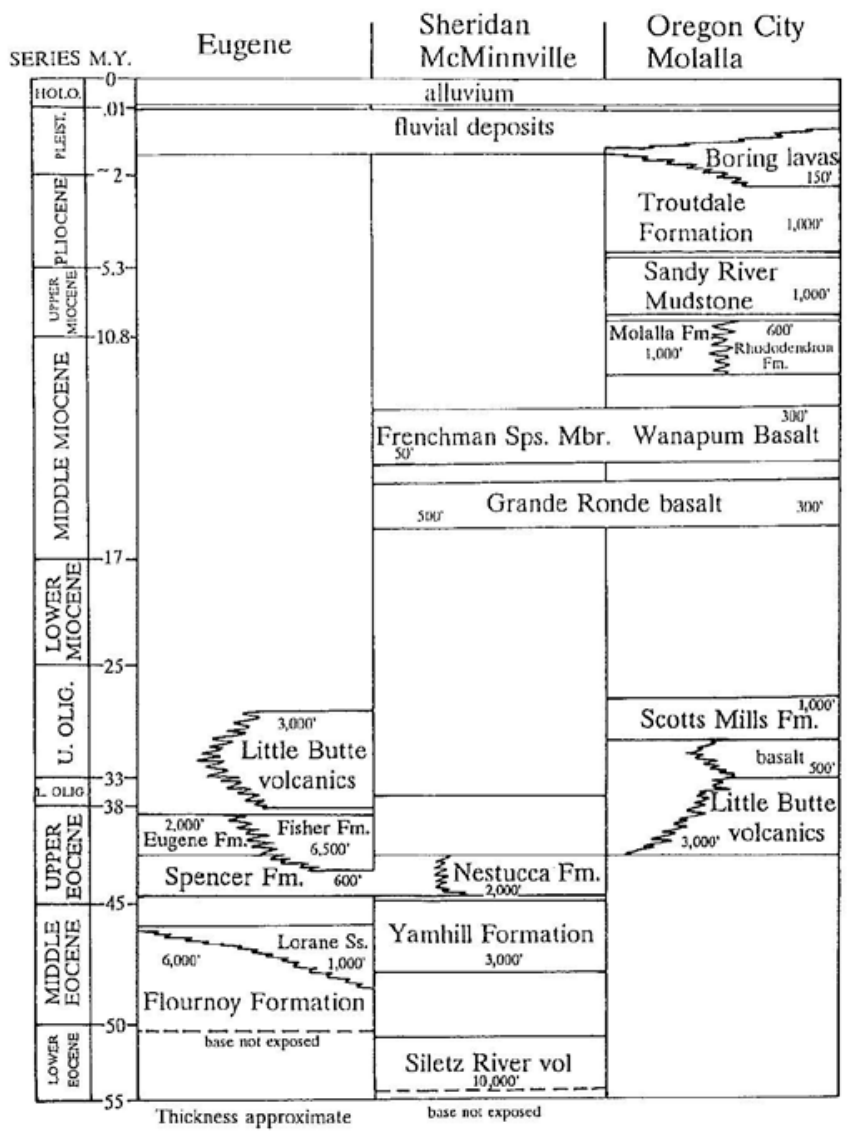

Figure 7: The stratigraphy of the Willamette Basin. After Orr and Orr, 1999 
During the Eocene, the Klamath Mountains and Idaho batholith eroded and subsidence resulted in the creation of the trough shape that defines this physiographic province. The thick sandstones of the middle Eocene Flournoy and Lorane formations were deposited in the southern Willamette Basin during this time (Orr and Orr, 1999). These formations are marine in origin as evidenced by their rhythmic bedding and microfossils (Orr and Orr, 1999).

Subsequently, in the southern part of the basin, the shallow marine sediments of the Spencer Formation were deposited (Orr and Orr, 1999). These were followed by deposition of the tuffs and conglomerates of the Fisher Formation and siltstones and sandstones of the Eugene Formation in the upper Eocene (Orr and Orr, 1999). The Fisher Formation contains fossils indicating a warm, wet, nearshore climate. Aquifers in both the Fisher and Eugene Formations have a known association with high levels of arsenic (Hinkle and Polette, 1999).

In the northern portion of the Willamette Valley, the stratigraphic sequence begins with the volcanic rocks of the Little Butte Volcanic Series in the upper Eocene and lower Oligocene (Orr and Orr, 1999). These were locally covered by the upper Oligocene Scotts Mill Formation's marine sediments and coals (Orr and Orr, 1999).

Plate tectonics resulted in the tilting of these Scotts Mill Formation sediments, along with a significant gap in deposition during the upper Oligocene and lower Miocene, (Orr and Orr, 1999). This hiatus of deposition ended during the middle Miocene when extensional tectonics resulted in the eruption of the Columbia River flood basalts in Eastern Oregon. The middle Miocene Grand Ronde basalts in the 
central and north Valley represents the onset of this volcanism, along with the overlying Wanapum Basalts and Frenchman Springs Member (Orr and Orr, 1999). In the northern Willamette Valley, the mudflows, clastics, and volcaniclastic sediments of the middle Eocene Molalla Formation overly the Columbia River Basalt group and represent a terrestrial environment of deposition (Orr and Orr, 1999).

During the upper Miocene, the Sandy River Mudstones, comprised of silts, conglomerates, and sandstones, were deposited in the northern Basin as fine-grained fluvial and lake sediments as tributaries of the Willamette River transported sediment into the Basin (Orr and Orr, 1999). This fluvial environment is associated with the late Pliocene Troutdale gravels (Orr and Orr, 1999).

The recent geologic history of the Willamette Basin is represented by the deposition of the Boring Lavas and ice age flood processes, as evidenced by Missoula Flood deposits. The Pliocene-Quaternary Boring Lavas were erupted during the Pliocene from the numerous volcanic vents across the northern Basin (Orr and Orr, 1999). The Missoula Flood deposits were deposited during the late Pleistocene between $18,000-15,000$ years B.P. as Glacial Lake Missoula broke through its ice dam flooding this region over 40 times (Allen et al., 2009).

\subsection{4: THE CASCADE RANGE}

\subsubsection{1: CASCADE RANGE GEOGRAPHY}

The north-south trending Cascade Mountain Province extends between $122.6^{\circ}$ and $121.1^{\circ}$ west longitude. It is characterized by volcanic high peaks, some in excess 
of 3400 meters (Orr and Orr, 1999). Mount Hood is arguably the most prominent volcanic peak within this province and is among other separate volcanic vents including stratovolcanoes, shield volcanoes, lava domes and cinder cones. The Cascades are comprised of two mountain chains, in the east and in the west, based on age of volcanism. The Western Cascades are older, with volcanism starting approximately $37 \mathrm{Ma}$. Most present-day Cascade volcanoes are less than 2 million years old.

Glacial influence on this province is significant, with both active glaciers and glacial landforms present throughout the province. This province experiences significant rainfall, and the geomorphology of this province is heavily influenced by erosion caused by this precipitation (Orr and Orr, 1999).

\subsubsection{2: CASCADE RANGE GEOLOGY}

The stratigraphic column of the Cascade Mountain Range, as illustrated by Orr and Orr (1999) is provided in Figure 8 . As with the stratigraphic columns describing the geologic units in the Coast Range and Willamette Valley, this stratigraphic column is separated by location. As with the Coast Range and Willamette Valley provinces, the stratigraphy of the Cascade Range begins with the Farallon Plate subducting under the North American plate over the last 37 Ma (Orr and Orr, 1999). The lithologies that comprise the geology of this province are primarily basalts, basaltic andesites, and other volcanics. 
The Miocene Rhododendron and Sardine Formations are found in this province and are of particular interest to this study. The early to middle Miocene Sardine Formation is comprised of basaltic and andesitic flows and lahars, dacitic tuffs, intermediate lavas, breccias and tuffs (Orr and Orr, 1999). The Rhododendron Formation, which is middle to late Miocene in age, contains pyroclastic tuff breccias, laharic breccias, conglomerates, sandstones, mudstones, tuffs and andesite flows (Gullixson, 2006).

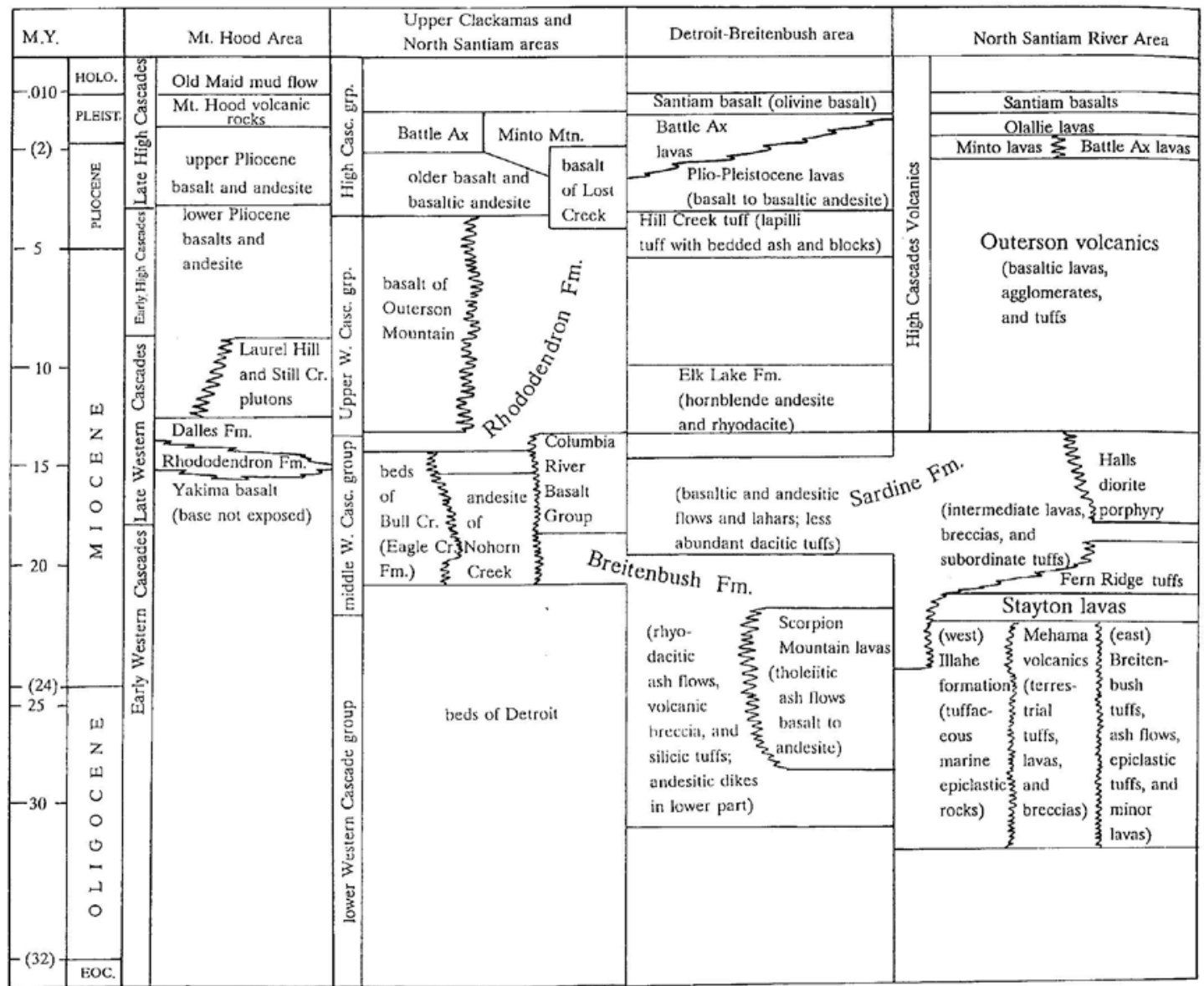

Figure 8: The Stratigraphy of the Cascade Mountain Range Province After Orr and Orr, 1999 


\section{2: SITE CHARACTERIZATIONS}

Each site sampled during Phase I fieldwork for the Ashbaugh (1995) study is described in Appendix C: Site Observations for Phase I (1995) Sites (Ashbaugh, 1995). The soil samples collected during this phase are described in Appendix D: Description of Phase I Soil Samples (Ashbaugh, 1995). Sites and soil samples collected during Phase II fieldwork in August 2010 are described in Appendix E: Site Observations for Phase II (2010) and Appendix F: Description of Phase II Soil Samples (2010) respectively. Photographs of the soil pit and site environment for each Phase II site are included in Appendix G: Site and Soil Pit Images from Sites Sampled During Phase II Sampling (2010).

\subsection{1: VEGETATION}

All soil pits from which samples were taken for this project were dug at sites judged to have minimal anthropogenic input of arsenic. These consisted primarily of forested areas. The primary foliation at these sites consists of western hemlock and Douglas fir trees. Maple, cedar, and alder trees were also commonly noted. Other types of vegetation noted include sagebrush, grasses, and ferns.

\subsection{2: SOIL CHARACTERIZATION}

The following summarizes the soil characteristics of soil samples collected during Phase II sampling (Appendix F: Description of Phase II Soil Samples (2010). The thickness of the A horizon at the pits dug varied from 2 to $15 \mathrm{~cm}$, most being less 
than $12 \mathrm{~cm}$. B horizon samples were taken from depths primarily between 35 and 45 $\mathrm{cm}$. Most pits were not deep enough to reach the bottom of the B horizon. The majority of sites exhibited Bw soils, suggesting these soils are relatively young. Sites where Bt horizons are present exhibit older and more developed soils (Birkeland, 1999). Sampled soils exhibited similar loamy textures. Samples exhibited weak to well-developed subangular blocky texture. All sites exhibited well-drained soils. Bhorizon samples were collected from the zone of maximum red color when possible. Few sampled soils were very red, or iron-inundated, and most were characterized as primarily brown in color. This lack of wide spread iron-inundation is most likely due to the young age of many of these soils (Burns et al., 1991; Birkeland, 1999) 


\section{CHAPTER 4: METHODS}

\section{1: USING GEOGRAPHIC INFORMATION SYSYSTEMS (GIS) TO DETERMINE UNSAMPLED GEOLOGIC MAP UNITS}

The geologic base map used for this study was obtained online from the United States Geological Survey (Walker and MacLeod, 1991). This map was downloaded as an ESRI shapefile, and ArcGIS version 10.0 was used throughout the analysis.

The study area was first isolated within ArcGIS (Figure 1). Areas representing the same geologic unit were combined for reasons of map usability. Areas labeled with a geologic unit and including a question mark signifying the area's bedrock geologic unit classification was unsure were assumed to be the unit that they were labeled. These areas were combined with the other areas where that unit was mapped.

The process of choosing geologic units for sampling during Phase II sampling was conducted within an Arc geodatabase. The geologic units whose overlying soils were not sampled during Phase I sampling were manually selected and separated into a new feature class. The total area within this project's study area that these remaining units covered was calculated. The eight of these geologic units that covered the largest amount of area were chosen for sampling during Phase II Sampling and are illustrated in Figure 9. 


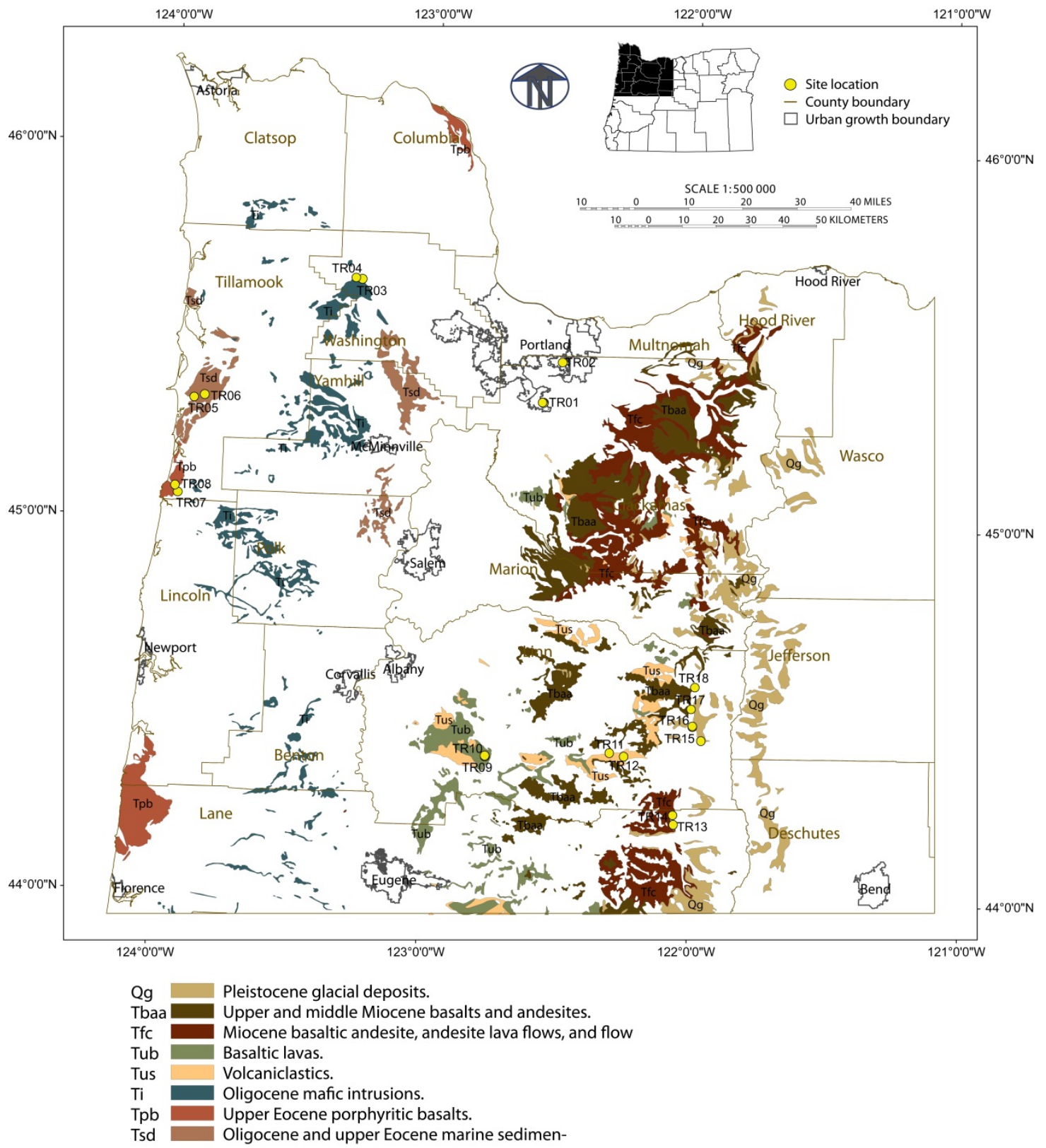

Figure 9: Location of sites sampled during Phase II (2010) fieldwork along with geologic unit associations. Unit labels and descriptions after Walker and MacLeod, 1991. 


\section{2: FIELDWORK}

Fieldwork for this project was done in two phases, the first being conducted in 1995 and the second in 2010. Seventy five sites were sampled during Phase I, and eighteen sites were sampled during Phase II. The methods used during the 2010 phase of fieldwork were modeled from the methods used in 1995 for purposes of continuity. Sampling for Phase II took place over the course of two days in August 2010. The underlying geologic unit at each site could not be independently verified, and locations were determined to be within a given unit based on the geologic map (Figure 9). To minimize the amount of anthropogenic arsenic in the collected samples, sites were chosen in wooded areas away from roads.

Once specific sites were chosen, soil pits were dug using shovels to approximately 60 centimeters deep. One-half to three-quarters of a gallon bag (approximately $1 \mathrm{~kg}$ ) of soil from the A and B horizons were collected, placed in sealable plastic bags, and labeled with the site label and horizon. The A horizon was sampled in the top $4 \mathrm{~cm}$ of soil over an area approximately $35 \mathrm{~cm}$ by $35 \mathrm{~cm}$. B horizon samples are composite samples taken from all walls of the pit at the zone of maximum red color.

Site locations were taken with a Garmin GPS. The techniques of Birkeland (1999) were used to compile notes about the soil itself including color, texture, and structure (Appendix E: Site Observations for Phase II (2010) Sites; Appendix F: Description of Phase II Soil Samples (2010)). The Munsell Color Book was used to determine the color of the dry soil samples. Digital photographs of each soil pit and 
the surrounding site were taken in part to help document the vegetation at the site (Appendix G: Site and Soil Pit Images from Sites Sampled During Phase II Sampling (2010)). Each site was restored to its previous condition after sampling.

\section{3: LABORATORY ANALYSIS}

The soil samples discussed in this study were prepared, inspected, and analyzed in the following manner.

Phase II samples were dried through the Portland State University lab by spreading them onto newspaper and leaving them for one to three days to ensure complete drying. These samples were sieved using a number 10 sieve. Approximately 340 grams of the sieved sample was placed into a labeled sealable bag for transport to the commercial laboratory. No formal splits from Phase I or Phase II samples were taken because the samples were considered well homogenized through composite sampling at collection, drying, and sieving.

Samples that had been collected during Phase I also required preparation for laboratory testing. Some samples had already been sieved, and approximately 340 grams ounces of soil per sample were placed into labeled and sealed bags. Samples collected during Phase I sampling that had not yet been sieved were sieved using a number 10 sieve, then bagged and labeled in a manner consistent with the Phase II samples.

A comprehensive list of samples was compiled in preparation for testing. Sites that did not have samples from both the $A$ and $B$ horizon were excluded from 
testing. Samples were boxed and transported to Apex Labs in Tigard, Oregon for testing. A total of 186 samples from 93 sites were tested for arsenic content.

Apex Labs used Inductively Coupled Plasma Mass Spectrometry (ICP-MS) to determine the amount of arsenic in each sample. Environmental Protection Agency method EPA 6020 was used (EPA, 2007). This method utilizes nitric acid $\left(\mathrm{HNO}_{3}\right)$ as the solute for sample preparation. Although a total of seven metals, including lead, were tested for, only the arsenic levels are discussed in this project so that these measurements could be focused on in more detail. The benefit of using ICP-MS in this study is its low detection limit of .01 ppm for arsenic (Personal communication, David Jack, Apex Labs, October 2012).

The accuracy of the results returned by APEX Laboratories is summarized in Appendix H: Example page from APEX Laboratory's. This appendix is referred to throughout this discussion on laboratory accuracy and is an example of approximately 15 analyses that were conducted throughout the laboratory analysis. Every morning, the ICP-MS is calibrated over the course of two hours. After every ten samples, three control samples are run for quality assurance purposes. The first sample is a blank for which all values should return ND, or nondetect. This sample is run to ensure no cross-contamination in the analytical methodology. The first analyte (sample 1004105-BLK1) reported in Appendix H: Example page from APEX Laboratory's Quality Control Sample Results detects no arsenic and is an example of this. Second, a check standard with known amounts is run to check for analytical accuracy. Per sample two in Appendix H: Example page from APEX Laboratory's 
Quality Control Sample Results (sample 1004105-B51), the known amount of arsenic was $50 \mathrm{ppm}$ and the reported value $48.9 \mathrm{ppm}$, a difference of $1.1 \mathrm{ppm}$. This represents a 98\% recovery, well within the laboratory's $80-120 \%$ recovery limit. Lastly, to check for precision, a previously run sample is retested. In the case of the third sample in Appendix H: Example page from APEX Laboratory's Quality Control Sample Results, the original reported value was $2.81 \mathrm{ppm}$ arsenic and the retest measured a value of $2.69 \mathrm{ppm}$ arsenic, a difference of .12 ppm. This represents a relative percent difference (RPD) of 5\%, well within the laboratory's QAQC limit of $40 \%$.

In order to ensure that the laboratory analysis was returning consistent values, five $A$ and five $B$ horizon samples from pit TR6 were analyzed as a measure of precision. For this analysis, A and B horizon soil was sampled from around the pit per the composite sampling method used at all sites. Five homogonized samples from each were analyzed from these composite samples (Mason, 1992). According to Mason (2002), this composite type of sampling is known to result in large standard deviations and should be used cautiously. The benefit of this method is that it is a cost effective way of determining where arsenic levels require further analysis (Mason, 1992; Oregon DEQ, 2006). The results of the analysis from this pit, along with means and standard deviations, are included in Table 2 below. The standard deviations here are under $30 \%$ for the A horizon data, and under $5 \%$ for the $\mathrm{B}$ horizon data. These results suggest that the variability within the $A$ and $B$ horizon composite samples at site TR6 is low, much more so than the differences between similar soils 
from different locations (as discussed in 5.1: GENERAL OVERVIEW OF DATA), lending validity to this method of sampling and sample processing at this site.

Table 2: Measured arsenic values and basic statistics for pit TR6.

\begin{tabular}{|c|c|c|}
\hline Sample Number & A Horizon As Value & B Horizon As Value \\
\hline TR6-1 & 6.04 & 11.3 \\
\hline TR6-2 & 4.64 & 10.9 \\
\hline TR6-3 & 6.48 & 10.2 \\
\hline TR6-4 & 3.39 & 11 \\
\hline TR6-5 & 3.54 & 11.4 \\
\hline Mean & 4.82 & 10.96 \\
\hline Standard Deviation & 1.41 & 0.47 \\
\hline \multicolumn{2}{|r}{}
\end{tabular}

\section{4: GROUPINGS FOR STATISTIC ANALYSIS}

Prior to statistical tests being run, the data were aggregated into groups based on underlying bedrock (Walker and MacLeod, 1991). The rock types described in the Geologic Map of Oregon were used to group these data (Appendix I: Descriptions of Lithology by Lithologic Group; Walker and MacLeod, 1991). Groups were formed primarily based on age and lithology criteria in order to minimize differences in the arsenic content of the overlying soil based on these factors. These groupings are referred to as lithologic groups and are described in Table 3. A table of measured A and B horizon arsenic, underlying geologic unit and assigned lithologic group is found in Appendix J: Soil Arsenic Data from Northwest Oregon. Table 3 also includes the units that comprise each group. The lithologic groups are titled Quaternary/ Tertiary Sediments and Sedimentary Rocks (QTS), Marine Sediments and Sedimentary Rocks (MS), Mafic Intrusions (MI), Coast Range Basalts (CORB), 
Columbia River Basalts (CRB), Quaternary Basalts (QB), Andesites (A), Rhododendron/Sardine Formation (RS), and Volcanic Sediments (VS) (Table 3; Appendix I: Descriptions of Lithology by Lithologic Group). The geographic distribution of these lithologic groups together with sample locations from both Phase I and Phase II sampling are shown in Figure 10.

In addition to having common age and similar rock types, the lithologic groups have additional noteworthy traits. The Quaternary/ Tertiary Sediments group includes Missoula Flood deposits, the Troutdale Formation, alluvium, glacial till, stream terraces, and loess. The Marine Sediments and Sedimentary Rocks group includes sandstones and shales primarily found in the Coast Range Province. The Mafic Intrusions units are also primarily found in the Coast Range and include basalt dikes and sills. Coast Range Basalts are older basalt flows, primarily from the Eocene. These early Tertiary basalts are in contrast to the Columbia River Basalts, which flow mostly from eastern Oregon and are Miocene in age. The Quaternary Basalt and Andesite groups consist of the young volcanic units of the Cascade Range Province. The Rhododendron/ Sardine Formation group is made of rocks of these lithologic units and is comprised of volcaniclastic sediments of early Cascade volcanism. 
Table 3: Lithologic Groups

\begin{tabular}{|c|c|c|}
\hline GROUP NAME $^{1}$ & UNIT LABEL ${ }^{2}$ & GROUP DESCRIPTION \\
\hline $\begin{array}{l}\text { Quaternary / Tertiary } \\
\text { Sediments and } \\
\text { Sedimentary Rocks }\end{array}$ & $\begin{array}{l}\text { Qal; Qs; Qg; } \\
\text { QTs; Ts; Qgs }\end{array}$ & $\begin{array}{l}\text { The Quaternary/ Tertiary sediments group } \\
\text { is characterized by sediments and } \\
\text { sedimentary rock from recent geologic } \\
\text { time periods, primarily the quaternary. }\end{array}$ \\
\hline $\begin{array}{l}\text { Marine Sediments and } \\
\text { Sedimentary Rocks }\end{array}$ & $\begin{array}{l}\text { Tco; Tms; } \\
\text { Tmst; Tsd; Tss; } \\
\text { Tt;Ty }\end{array}$ & $\begin{array}{l}\text { The Marine Sediments and Sedimentary } \\
\text { Rocks group is characterized by } \\
\text { sedimentary rocks deposited in a marine } \\
\text { environment. Each of the groups is } \\
\text { Tertiary in age. }\end{array}$ \\
\hline Mafic Intrusions & $\mathrm{Ti}$ & $\begin{array}{l}\text { The Mafic Intrusion group is Oligocene in } \\
\text { age and made up only of unit Ti. }\end{array}$ \\
\hline Coast Range Basalt & Tsr; Ttv & $\begin{array}{l}\text { The Coast Range Basalts group is } \\
\text { composed of basalts deposited during the } \\
\text { Tertiary. Geographically, these basalts are } \\
\text { found in the Coast Range physiographic } \\
\text { province. }\end{array}$ \\
\hline Columbia River Basalts & $\begin{array}{l}\text { Tc; Tcg; Tob; } \\
\text { Tpb;Tub }\end{array}$ & $\begin{array}{l}\text { The Columbia River Basalts are extensive } \\
\text { geographically and were deposited during } \\
\text { the Tertiary. }\end{array}$ \\
\hline Quaternary Basalts & $\begin{array}{l}\text { QTb; QTba; } \\
\text { Qyb }\end{array}$ & $\begin{array}{c}\text { The Quaternary basalts group is defined by } \\
\text { a Quaternary period of deposition and a } \\
\text { basaltic lithology. }\end{array}$ \\
\hline Andesites & Qa & $\begin{array}{l}\text { The Andesite unit was deposited during } \\
\text { the Quaternary geologic time period. }\end{array}$ \\
\hline $\begin{array}{l}\text { Rhododendron / } \\
\text { Sardine Formations }\end{array}$ & Tbaa; Tfc & $\begin{array}{l}\text { The Rhododendron/ Sardine Formation } \\
\text { rocks are of primarily basaltic and andesitic } \\
\text { lithology and were deposited during the } \\
\text { Tertiary time period. }\end{array}$ \\
\hline Volcanic Sediments & $\begin{array}{l}\text { Tca; Tus; Tsfj; } \\
\text { Tu }\end{array}$ & $\begin{array}{l}\text { The Volcanic Sediments group is comprised } \\
\text { of sedimentary rocks deposited during the } \\
\text { Tertiary. These rocks are comprised of } \\
\text { sediments that are volcanic in origin. }\end{array}$ \\
\hline
\end{tabular}

1. Informal Designation

2. See Appendix I: Descriptions of Lithology by Lithologic Group for full unit descriptions. 


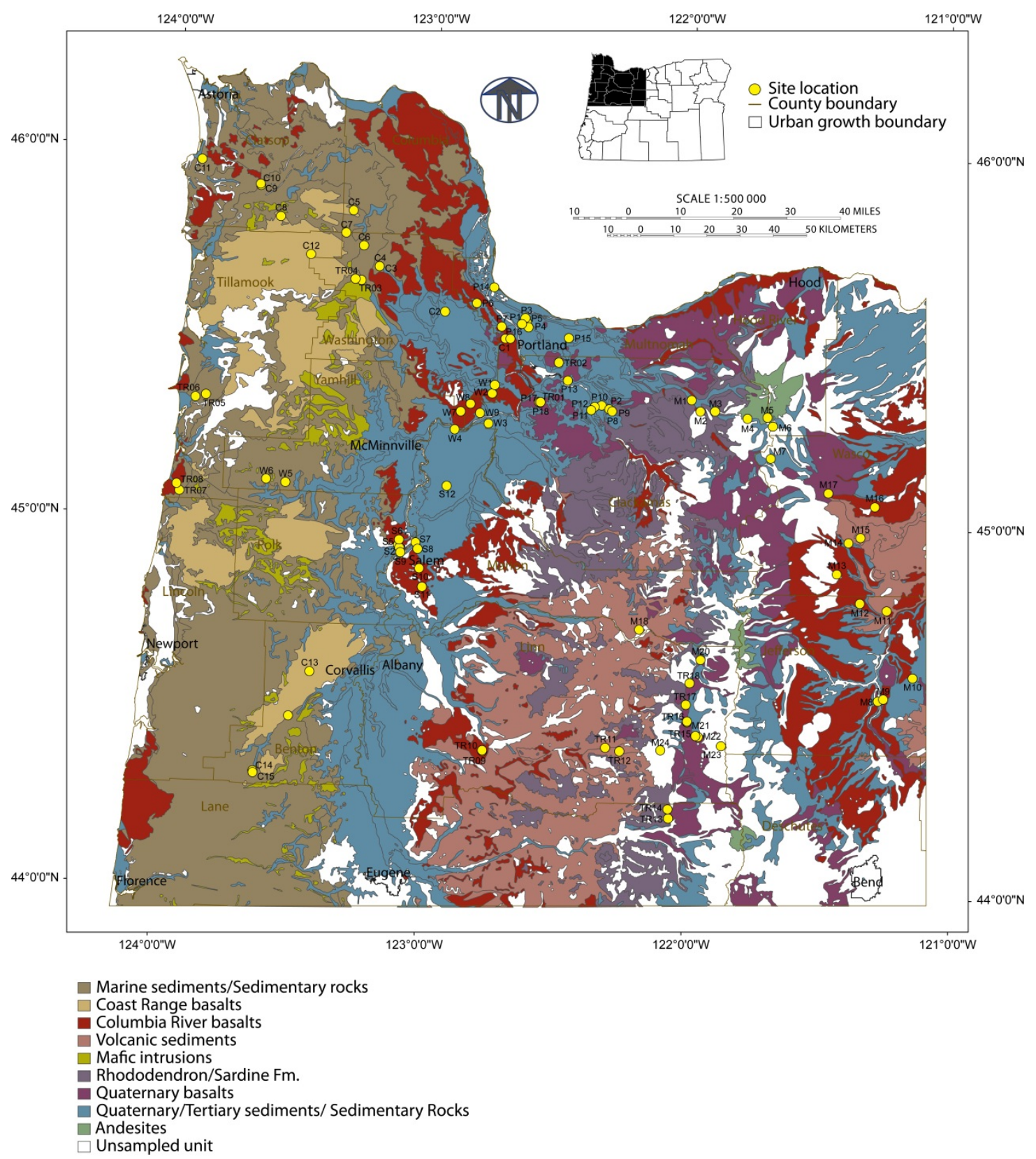

Figure 10: Geographic extent of lithologic groups and all site locations (Walker and MacLeod, 1991; Ashbaugh, 1995). 


\section{CHAPTER 5: ANALYSIS}

\section{1: GENERAL OVERVIEW OF DATA}

The levels of arsenic measured in each sample, the underlying bedrock unit, and assigned lithologic group of each data point are included in Appendix J: Soil Arsenic Data from Northwest Oregon. A table of high and low values tested in each horizon and number of samples in each horizon from which no arsenic was detected, grouped by underlying geologic unit, is included as Appendix K: High and Low Values for Samples by Mapping Unit. The mean arsenic level and standard deviations of five lithologic units tested in five or more pits are noted in Table 4 and Table 5 (Appendix J: Soil Arsenic Data from Northwest Oregon). The mean arsenic level and standard deviations of five lithologic groups containing six or more data points are noted in Table 6 and Table 7 (Appendix J: Soil Arsenic Data from Northwest Oregon). Four lithologic groups (the Andesites, Mafic Intrusions, Rhododendron/ Sardine Formations and Coast Range Basalts groups) are not included due to low sample size. 
Table 4: Overview of arsenic data in the A horizon by unit.

\begin{tabular}{|c|c|c|c|c|}
\hline $\begin{array}{c}\text { Lithologic } \\
\text { Unit }\end{array}$ & $\begin{array}{c}\text { A Horizon } \\
\text { Mean (ppm) }\end{array}$ & $\begin{array}{c}\text { A Horizon } \\
\text { Median } \\
\text { (ppm) }\end{array}$ & $\begin{array}{c}\text { A Horizon } \\
\text { Standard } \\
\text { Deviation (ppm) }\end{array}$ & $\begin{array}{c}\text { Number of } \\
\text { Samples per } \\
\text { Horizon }\end{array}$ \\
\hline Qal & 3.04 & 3.08 & 2.654 & 7 \\
\hline Qgs & 6.94 & 9.20 & 5.17 & 5 \\
\hline Qs & 4.5 & 3.45 & 3.33 & 12 \\
\hline QTba & 1.67 & 1.45 & 1.77 & 12 \\
\hline Tc & 4.02 & 4.69 & 2.01 & 6 \\
\hline
\end{tabular}

1. Units here are those sampled in five or more pits. Other units were sampled, but included less than five points of data. These units are excluded from this chart, as the groups are too small for mean and standard deviation calculations to be meaningful.

2. A complete list of values, including minimum and maximum for each lithologic unit, is included in Appendix J: Soil Arsenic Data from Northwest Oregon and Appendix K: High and Low Values for Samples by Mapping Unit.

Table 5: Overview of arsenic data in the B horizon by unit.

\begin{tabular}{|c|c|c|c|c|}
\hline $\begin{array}{c}\text { Lithologic } \\
\text { Unit }\end{array}$ & $\begin{array}{c}\text { B Horizon } \\
\text { Mean (ppm) }\end{array}$ & $\begin{array}{c}\text { B Horizon } \\
\text { Median } \\
\text { (ppm) }\end{array}$ & $\begin{array}{c}\text { B Horizon } \\
\text { Standard } \\
\text { Deviation (ppm) }\end{array}$ & $\begin{array}{c}\text { Number of } \\
\text { Samples per } \\
\text { Horizon }\end{array}$ \\
\hline Qal & 2.97 & 2.79 & 2.80 & 7 \\
\hline Qgs & 3.87 & 3.53 & 1.64 & 5 \\
\hline Qs & 4.59 & 4.91 & 1.21 & 12 \\
\hline QTba & 1.79 & 1.25 & 1.94 & 12 \\
\hline Tc & 5.24 & 5.02 & 1.70 & 6 \\
\hline
\end{tabular}

1. Units here are those sampled in five or more pits. Other units were sampled, but included less than five points of data. These units are excluded from this chart, as the groups are too small for mean and standard deviation calculations to be meaningful.

2. A complete list of values, including minimum and maximum for each lithologic unit, is included in Appendix J: Soil Arsenic Data from Northwest Oregon and Appendix K: High and Low Values for Samples by Mapping Unit. 
Table 6: Overview of arsenic data in the A horizon by lithologic group

\begin{tabular}{|c|c|c|c|c|}
\hline Lithologic Group & $\begin{array}{c}\text { A Horizon Mean } \\
\text { (ppm) }\end{array}$ & $\begin{array}{c}\text { A Horizon } \\
\text { Median } \\
\text { (ppm) }\end{array}$ & $\begin{array}{c}\text { A Horizon } \\
\text { Standard } \\
\text { Deviation } \\
\text { (ppm) }\end{array}$ & $\begin{array}{c}\text { Number of } \\
\text { Samples per } \\
\text { Horizon }\end{array}$ \\
\hline $\begin{array}{c}\text { Quaternary/ } \\
\text { Tertiary } \\
\text { Sediments and } \\
\text { Sedimentary } \\
\text { Rocks }\end{array}$ & 3.59 & 3.25 & 3.72 & 32 \\
\hline $\begin{array}{c}\text { Marine } \\
\text { Sediments/ } \\
\text { Sedimentary } \\
\text { Rocks }\end{array}$ & 6.09 & 5.44 & 2.65 & 12 \\
\hline $\begin{array}{c}\text { Columbia River } \\
\text { Basalts }\end{array}$ & 3.75 & 4.54 & 2.31 & 15 \\
\hline $\begin{array}{c}\text { Quaternary } \\
\text { Basalts }\end{array}$ & 1.67 & 1.80 & 1.68 & 6 \\
\hline $\begin{array}{c}\text { Volcanic } \\
\text { Sediments }\end{array}$ & 2.45 & 0.00 & 4.29 & 15 \\
\hline
\end{tabular}

1. Lithologic groups here are those sampled by six or more pits. The Rhododendron/ Sardine Formation, Mafic Intrusions, and Andesites groups included less than six points of data. These groups are excluded from this chart, as the groups are too small for mean and standard deviation calculations to be meaningful.

2. A complete list of values, including minimum and maximum for each lithologic group, is included in Appendix J: Soil Arsenic Data from Northwest Oregon. 
Table 7: Overview of arsenic data in the B horizon by lithologic group.

\begin{tabular}{|c|c|c|c|c|}
\hline Lithologic Group & $\begin{array}{c}\text { B Horizon Mean } \\
\text { (ppm) }\end{array}$ & $\begin{array}{c}\text { B Horizon } \\
\text { Median } \\
\text { (ppm) }\end{array}$ & $\begin{array}{c}\text { B Horizon } \\
\text { Standard } \\
\text { Deviation } \\
\text { (ppm) }\end{array}$ & $\begin{array}{c}\text { Number of } \\
\text { Samples per } \\
\text { Horizon }\end{array}$ \\
\hline $\begin{array}{c}\text { Quaternary/ } \\
\text { Tertiary } \\
\text { Sediments and } \\
\text { Sedimentary } \\
\text { Rocks }\end{array}$ & 3.25 & 3.43 & 2.23 & 32 \\
\hline $\begin{array}{c}\text { Marine } \\
\text { Sediments/ } \\
\text { Sedimentary } \\
\text { Rocks }\end{array}$ & 10.26 & 10.73 & 4.65 & 12 \\
\hline $\begin{array}{c}\text { Columbia River } \\
\text { Basalts }\end{array}$ & 4.28 & 4.99 & 2.33 & 15 \\
\hline Quaternary \\
Basalts
\end{tabular}

1. Lithologic groups here are those sampled by six or more pits. The Rhododendron/ Sardine Formation, Mafic Intrusions, and Andesites groups included less than six points of data. These groups are excluded from this chart, as the groups are too small for mean and standard deviation calculations to be meaningful.

2. A complete list of values, including minimum and maximum for each lithologic group, is included in Appendix J: Soil Arsenic Data from Northwest Oregon.

\section{2: ANALYSIS OF VARIANCE AND MULTIPLE COMPARISON ANALYSIS}

Using soil arsenic measurements to make maps of expected background arsenic levels for soil types above different bedrock lithologies requires that the soils are statistically distinguishable. This is evaluated with an Analysis of Variance (ANOVA) test and a multiple comparison procedure which are used to compare means between the lithologic groups (Davis, 2002; Mathworks, 2012c). The soil data are grouped in two ways to test this project's motivating hypothesis. Data from 
individual sites are grouped according to underlying lithology, as discussed in the Methods section and Table 3. The data are alternatively considered as a single group. These groupings allow for the calculation of mean and standard deviation. This grouping strategy also allows conclusions to be drawn regarding the data in the absence of error estimates on individual sample sites.

The Analysis of Variance (ANOVA) test is used to determine if the five lithologic groups that have six or more samples in each horizon are statistically different from each other (Table 3, Table 6, Table 7). The procedure utilized here is chosen to avoid type I statistical errors that can occur when a T-test is used to directly compare two groups of data. The ANOVA analysis compares the variances both within and between the groups using an F-test. The null hypothesis states that there is no statistically distinguishable difference between the groups. The analysis is completed using lithologic groups for which six or more samples were tested: Quaternary/ Tertiary Sediments (QTS), Marine Sediments and Sedimentary Rocks (MS), Columbia River Basalts (CRB), Quaternary Basalts (QB), and Volcanic Sediments (VS). In addition to the typical assumptions underlying the ANOVA test, including that the data exhibit a normal distribution, specific assumptions made in this analysis include:

1. Samples are representative of both the bulk soil and the pit from which they were taken. (Because only one sample was taken in each horizon at most sites, the representative nature of the samples cannot be verified, and therefore must be assumed. 
2. Lithology of underlying bedrock at different locations are drawn from the same populations; making the grouped soils drawn from a single population for the purpose of the motivating hypothesis of this test.

The critical value for this test at the $95 \%$ confidence level is approximately 2.72 (Davis, 2002). If the F-test value for the $A$ and $B$ horizon tests are above this critical value, the null hypothesis is rejected, indicating that at least one group is statistically distinguishable from the rest (Davis, 2002). The results are provided in Table 8 and Table 9.

Table 8: A Horizon data ANOVA

\begin{tabular}{|c|c|c|c|c|c|}
\hline Source & $\frac{\text { Sum of }}{\text { Squares }}$ & $\begin{array}{l}\text { Degrees of } \\
\text { Freedom }\end{array}$ & $\underline{\text { Mean }}$ & $\begin{array}{l}\text { F-Test } \\
\text { Value }\end{array}$ & P-Value \\
\hline Groups & 138.06 & 4 & 34.51 & 3.63 & .0093 \\
\hline Error & 713.38 & 75 & 9.51 & & \\
\hline Total & 851.43 & 79 & & & \\
\hline
\end{tabular}

Table 9: B Horizon data ANOVA

\begin{tabular}{|c|c|c|c|c|c|}
\hline Source & $\underline{\text { Sum of }}$ & $\frac{\text { Degrees of }}{\text { Freedom }}$ & $\underline{\text { Mean }}$ & $\begin{array}{l}\text { F-Test } \\
\text { Value }\end{array}$ & P-Value \\
\hline Groups & 566.41 & 4 & 141.60 & 17.26 & $4.45 \times 10^{-10}$ \\
\hline Error & 615.22 & 75 & 8.20 & & \\
\hline Total & 1181.63 & 79 & & & \\
\hline
\end{tabular}

In order to determine which group or groups are statistically distinguishable, a multiple comparison test is required. This test is also conducted to diminish the possibility of a type II error given the large standard deviations within the lithologic 
groups. In this analysis, the MS group is found to be statistically distinguishable from the $Q B$ group in the $A$ horizon, and all groups in the $B$ horizon (Figure 13, Figure 14).

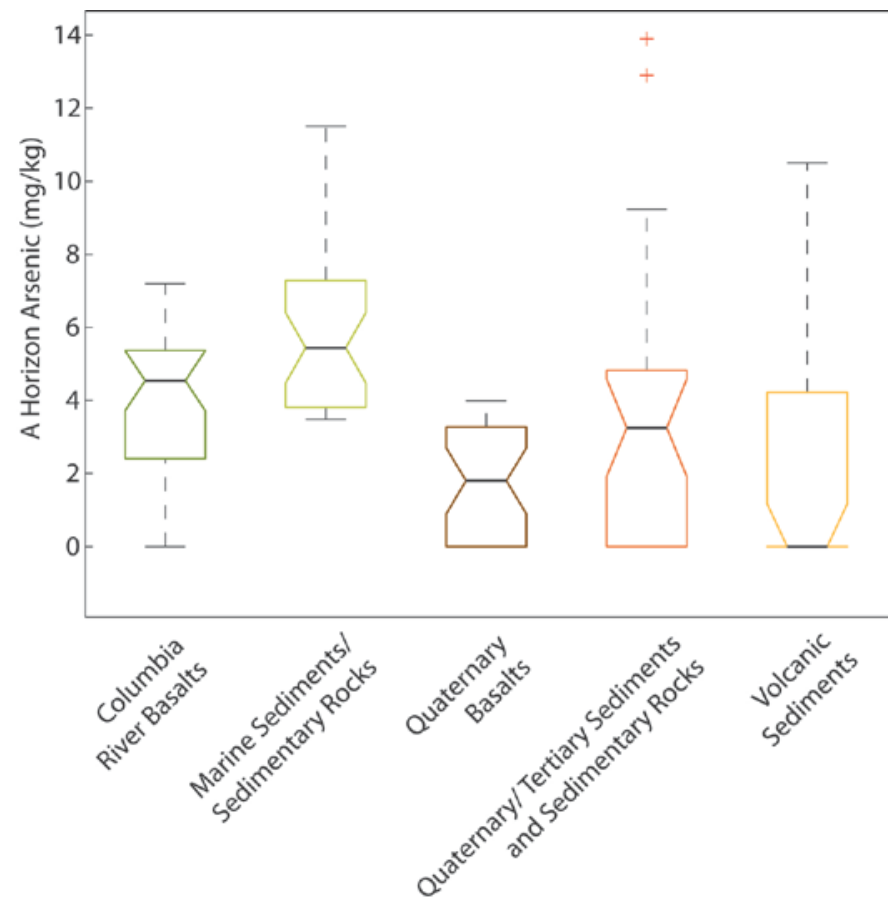

Figure 11: Stem-box plot showing mean, upper and lower quartile, data range, and outliers for the A horizon values of the five tested groups. 


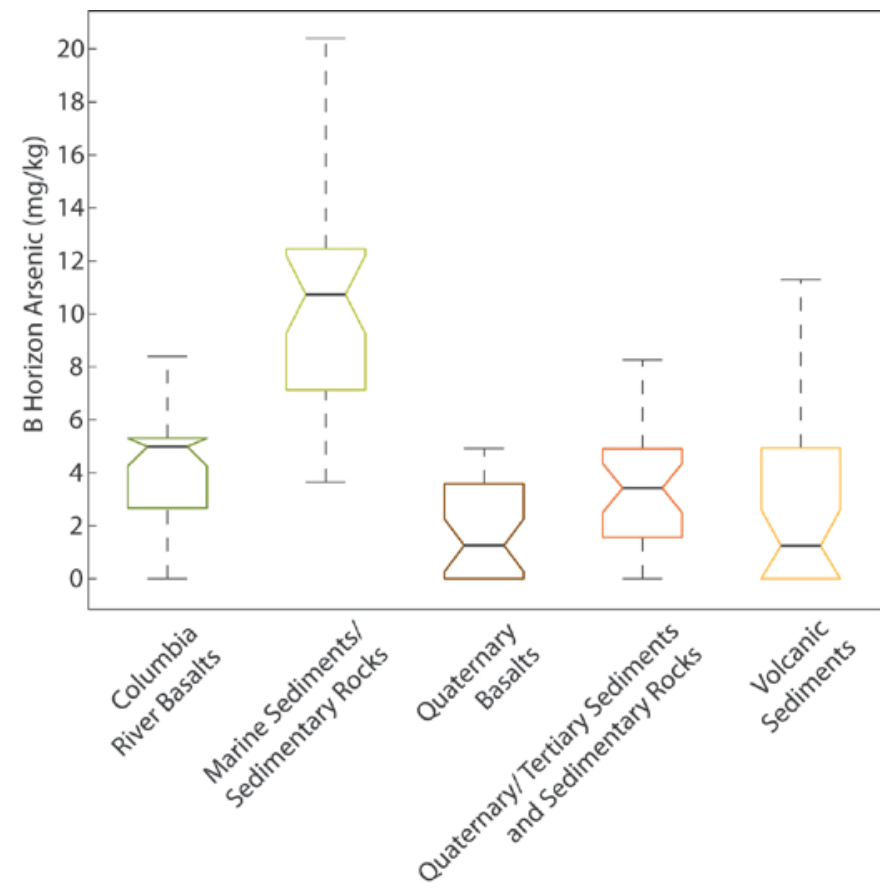

Figure 12: Stem-box plot showing mean, upper and lower quartile, data range, and outliers for the B horizon values of the five tested groups.

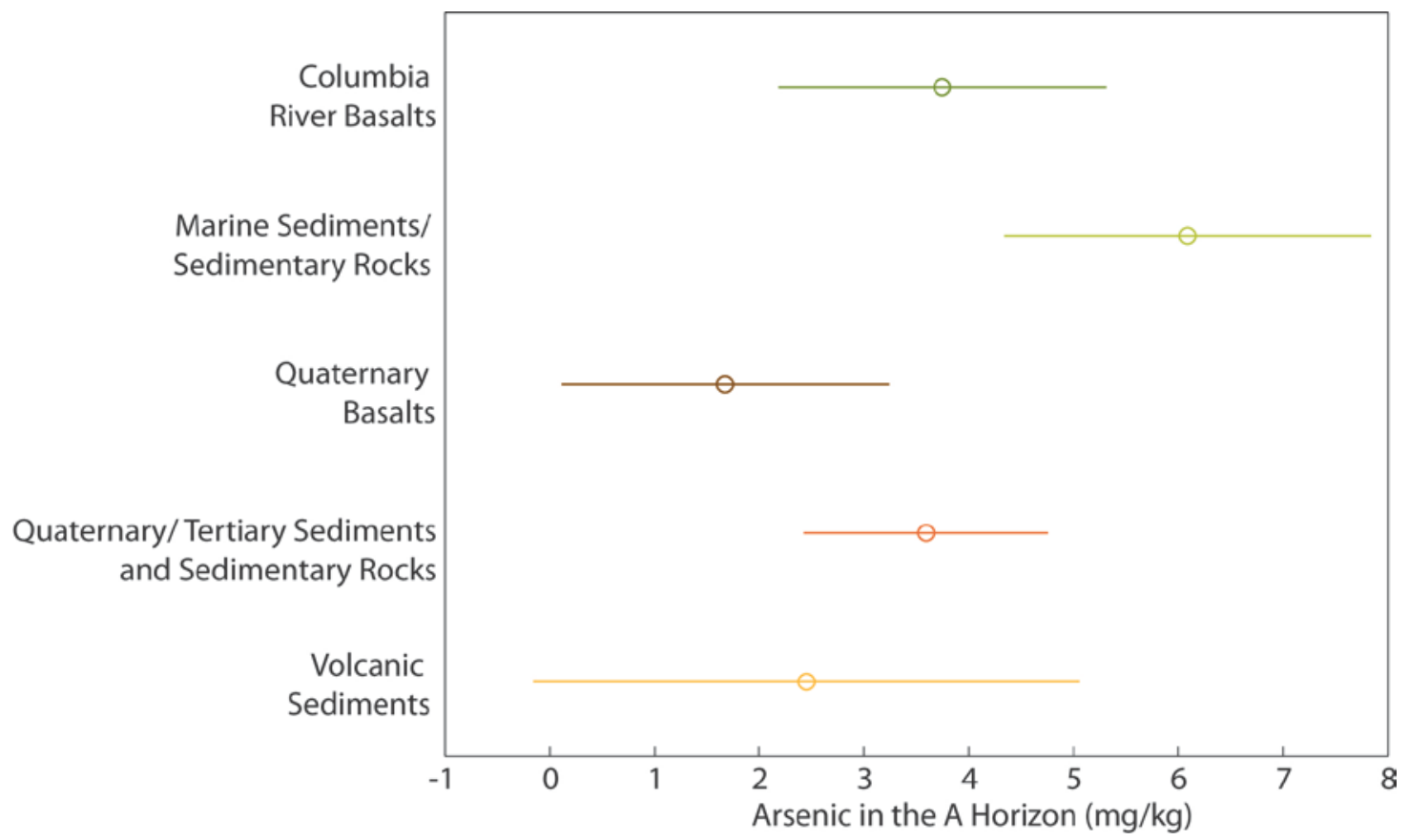

Figure 13: Multiple comparison of A horizon arsenic concentrations finds that group MS is distinct from group QB in this horizon. 


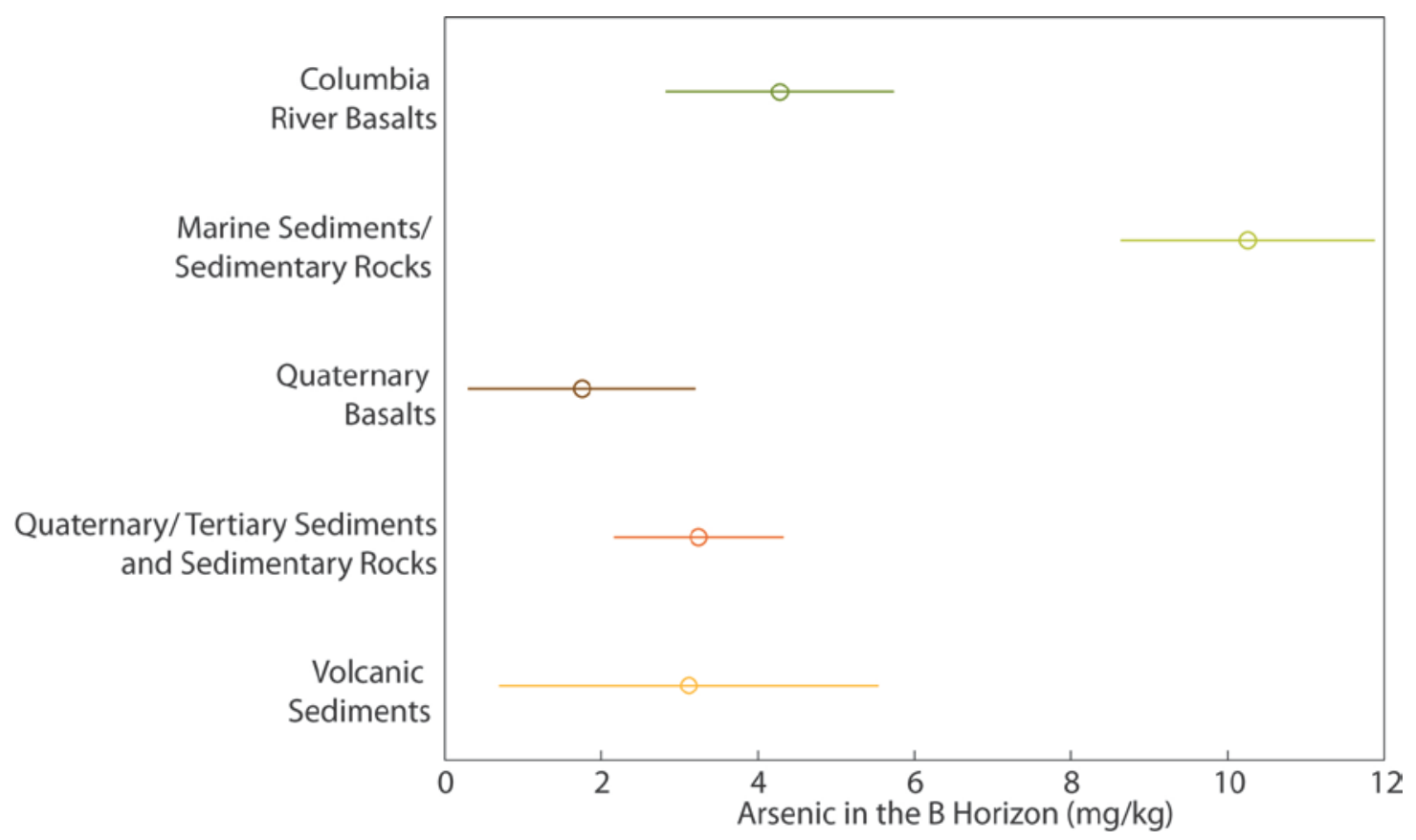

Figure 14: Multiple comparison of B horizon arsenic concentrations finds that group MS is distinct from all other tested groups in this horizon.

\section{3: KRUSKAL-WALLIS TEST}

The standard ANOVA assumption that the data are drawn from a normal distribution may not be appropriate here. A nonparametric alternative is the KruskalWallis analysis of variance (Davis, 2002; Mathworks, 2012b). As in the standard ANOVA analysis, the null hypothesis states that the different sample sets are drawn from the same distribution. The Kruskal-Wallis test compares the median of the samples in each group using the Chi-squared test. Values are ranked for comparison.

The critical value of the Chi-squared test with 4 degrees of freedom is approximately 9.49. The Chi-squared value is higher than this critical value in both the $A$ and $B$ horizon test (Table 10, Table 11). These results indicate a rejection of the null hypothesis and that at least one group is statistically distinct from another (Table 
10, Table 11). A multiple comparison analysis is again required to determine which group or groups are distinct (Figure 15, Figure 16).

Table 10: A Horizon Data Kruskal-Wallis Analysis

\begin{tabular}{|c|c|c|c|c|c|}
\hline Source & $\begin{array}{c}\text { Sum of } \\
\text { Squares }\end{array}$ & $\begin{array}{c}\text { Degrees of } \\
\text { Freedom }\end{array}$ & $\begin{array}{c}\underline{\text { Mean }} \\
\text { Squares }\end{array}$ & $\frac{\text { Chi-Squared }}{\underline{\text { Value }}}$ & $\underline{\text { P-Value }}$ \\
\hline Groups & 9736.9 & 4 & 2434.21 & 18.53 & .001 \\
\hline Error & 31772.6 & 75 & 423.64 & & \\
\hline Total & 41509.5 & 79 & & & \\
\hline
\end{tabular}

Table 11: B Horizon Kruskal-Wallis Analysis

\begin{tabular}{|c|c|c|c|c|c|}
\hline Source & $\frac{\text { Sum of }}{\text { Squares }}$ & $\frac{\text { Degrees of }}{\text { Freedom }}$ & $\frac{\text { Mean }}{\underline{\text { Squares }}}$ & $\frac{\text { Chi-Squared }}{\underline{\text { Value }}}$ & $\underline{\text { P-Value }}$ \\
\hline Groups & 15878.5 & 4 & 3969.63 & 29.74 & $5.52 \times 10^{-6}$ \\
\hline Error & 26295 & 75 & 350.6 & & \\
\hline Total & 42173.5 & 79 & & & \\
\hline
\end{tabular}

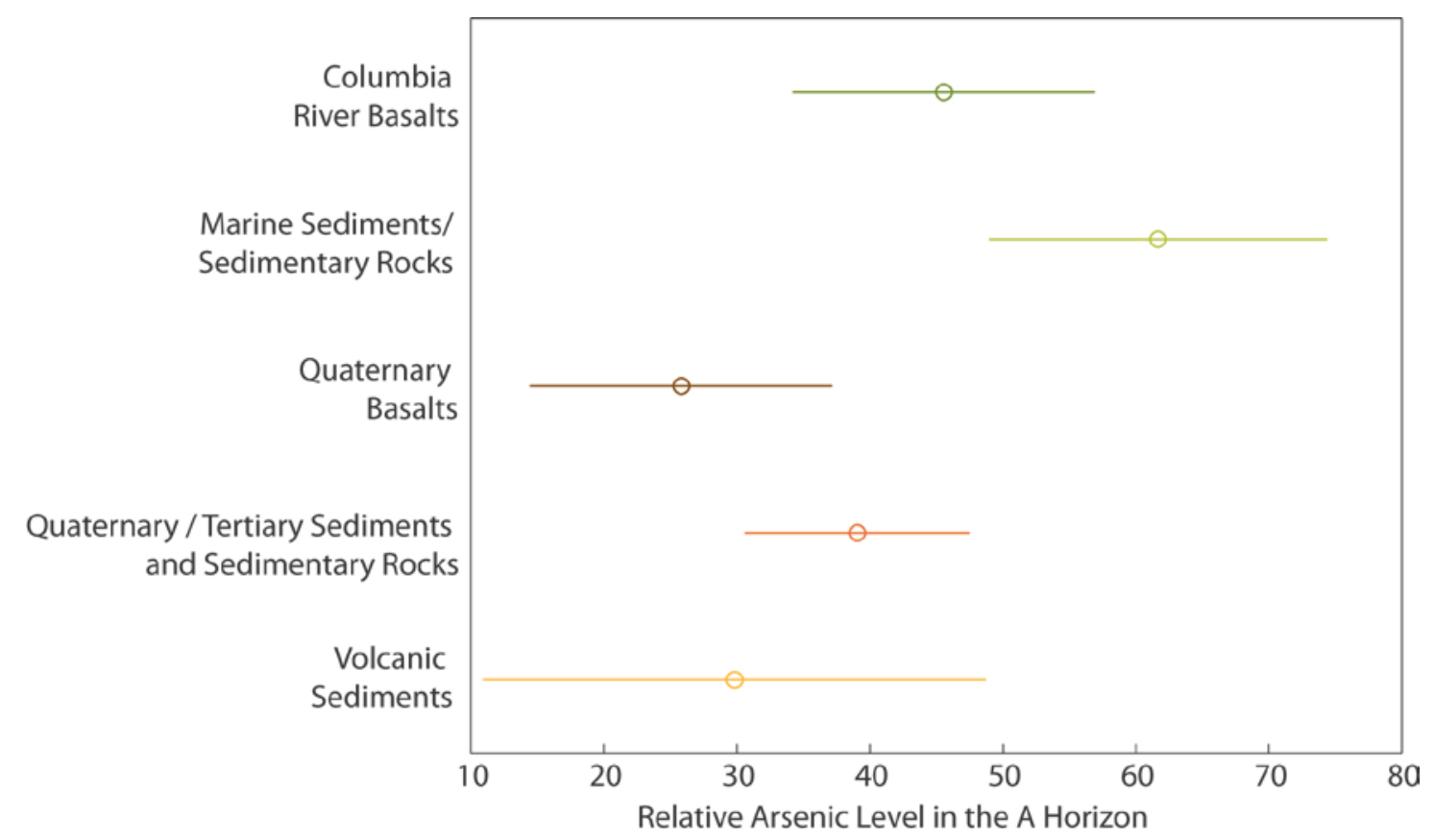

Figure 15: Multiple comparison test of A horizon data based on the Kruskal-Wallis analysis. This test shows the arsenic levels of group MS are statistically different from those of groups QB and QTS in the A horizon. The $X$ axis values represent the mean and standard deviation of the group's ranks. 


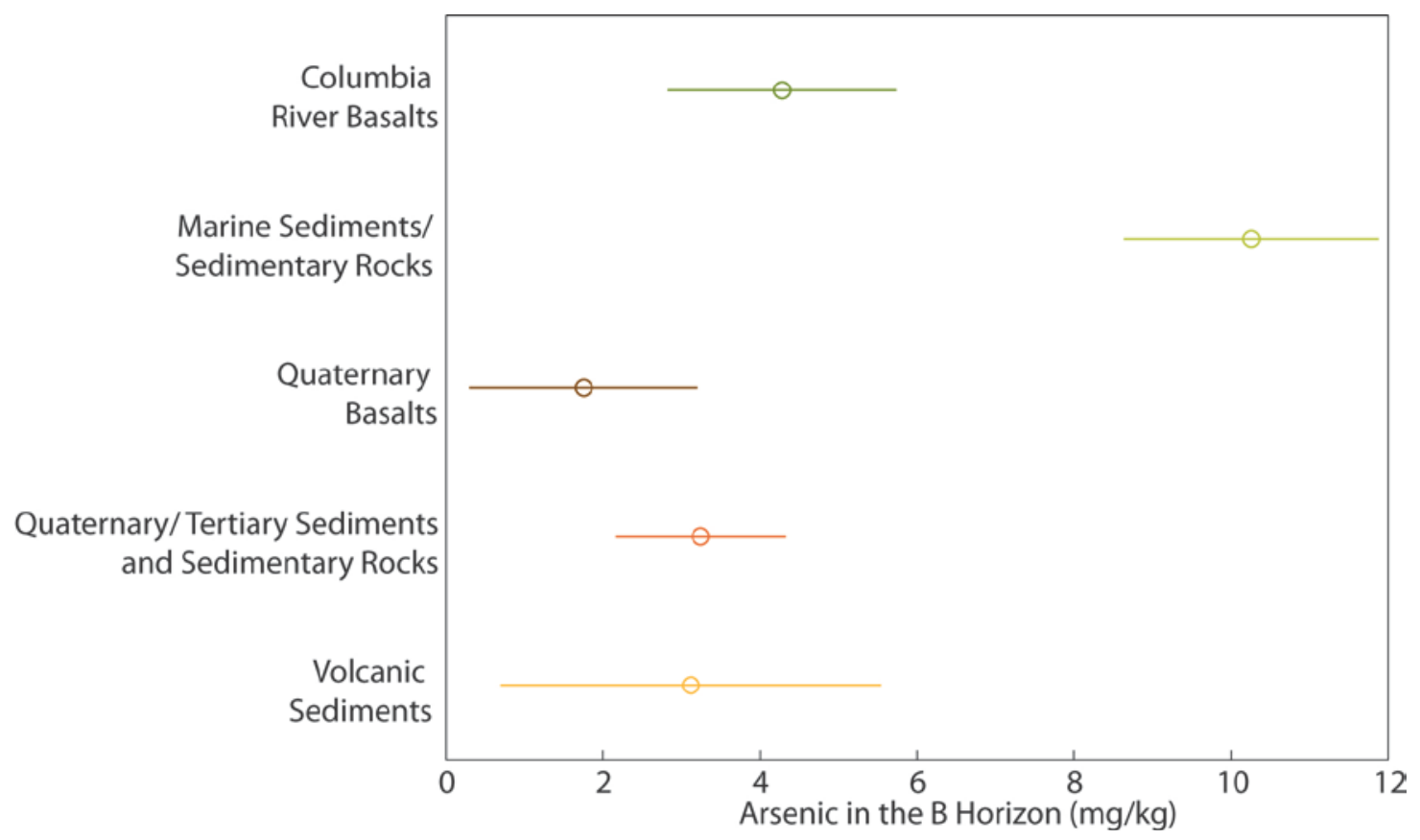

Figure 16: Multiple comparison test of B horizon data based on the Kruskal-Wallis analysis. This test shows the arsenic levels of group MS are statistically different from those of groups QB, QTS and VS in the B horizon. The X-axis values represent the mean and standard deviation of the group's ranks.

The multiple comparison test conducted from the Kruskal-Wallis analysis indicates, as in the standard ANOVA, that group MS is the only group that is statistically different from another group. In both the A and B horizon samples, group MS is statistically distinguishable from groups QB, QTS, and VS. This analysis supports the standard ANOVA test results.

For the purposes of making a map correlating underlying bedrock to arsenic content, the results of the standard ANOVA and Kruskal-Wallis tests indicate that the Marine Sediments and Sedimentary Rocks group should be considered one unit, and 
the other lithologic groups that were tested should be combined into a single separate unit. Lithologic groups that were not tested due to low sample size are distinguished from unsampled units for the purposes of this map. The basic mean and standard deviation of both tested horizons for these groups are noted in Table 12. The map correlating these underlying geologic units to the arsenic content of overlying soils is shown as Figure 17.

Table 12: Basic arsenic statistics of groups mapped based on analysis

\begin{tabular}{|c|c|c|c|c|}
\hline & \multicolumn{2}{|c|}{$\begin{array}{c}\text { Group containing all tested } \\
\text { data not in the Marine } \\
\text { Sediments and Sedimentary } \\
\text { Rocks Group }\end{array}$} & \multicolumn{2}{|c|}{$\begin{array}{r}\text { Marine Sediments and } \\
\text { Sedimentary Rocks Group }\end{array}$} \\
\hline Mean & A Horizon & B Horizon & A Horizon & B Horizon \\
\hline $\begin{array}{c}\text { Standard } \\
\text { Deviation }\end{array}$ & 3.10 & 3.13 & 6.09 & 10.26 \\
\hline $\begin{array}{c}\text { Number of } \\
\text { Samples }\end{array}$ & 3.19 & 2.52 & 2.66 & 4.65 \\
\hline
\end{tabular}




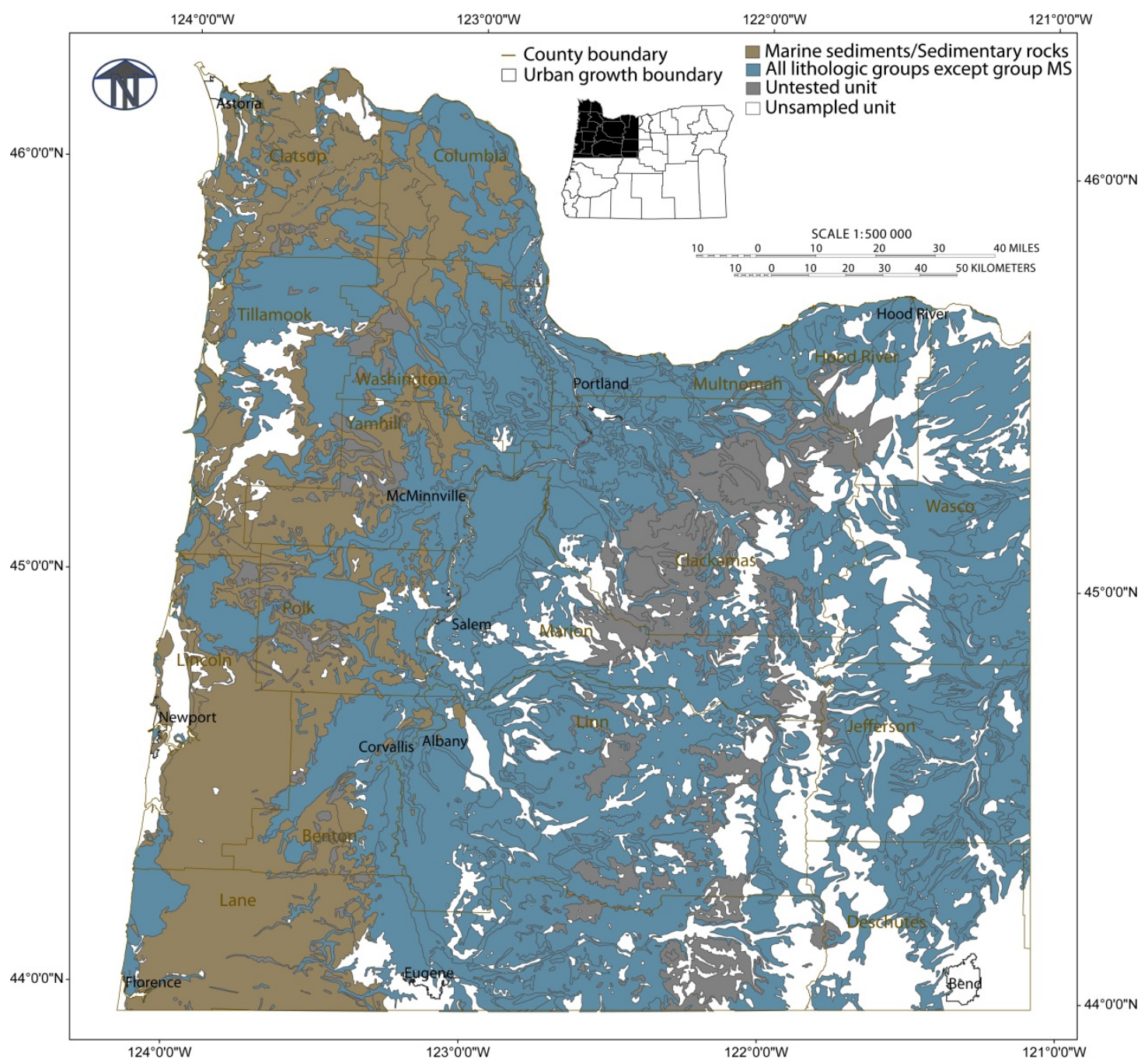

Figure 17: Map showing the distribution of Marine Sedimentary and Sedimentary Rocks group units and the other tested lithologic groups throughout the northwest Oregon study area. This map illustrates areas where soil arsenic content is statistically distinct (Walker and MacLeod, 1991). Mean, standard deviation and number of samples in each of these mapped groups are found in Table 12. Untested units are those from which overlying soils were sampled but for which the resulting data was unable to be used in the standard ANOVA or Kruskal-Wallis test due to these samples being a part of lithologic groups that had fewer than six samples. Unsampled units are those from above which soil samples were not collected and tested for arsenic content. 


\section{4: A VS B HORIZON ANALYSIS}

The $A$ and $B$ horizon arsenic data was looked at together to determine which, if any, groups were statistically distinguishable when data from both horizons was compared. An initial assessment of the data indicates that more arsenic was measured in the A horizon sample at 31 sites, more arsenic was measured in the $B$ horizon sample at 31 sites, and $A$ and $B$ horizon samples measured equal amounts of arsenic at 20 sites. In order to ascertain if A horizon data are statistically distinguishable from B horizon data, the standard ANOVA and Kruskal-Wallis tests are again implemented. Data are again grouped by lithologic group (Table 3, Table 6, Table 7). Both $A$ and $B$ horizon data are assessed together to compare data between horizons (Figure 18). 


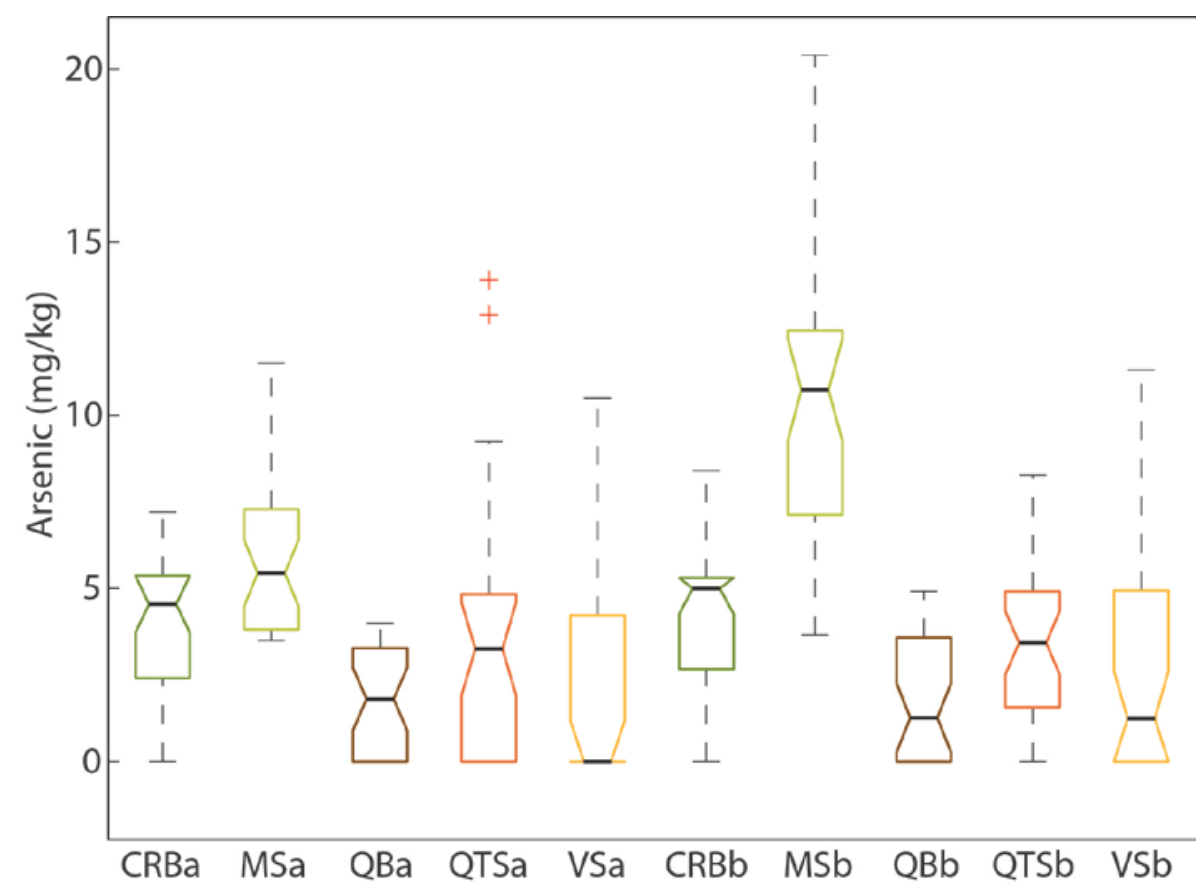

Figure 18: Stem-box plot showing mean, upper and lower quartile, data range, and outliers for A and B horizon data by lithologic group. X-Horizon labels indicate lithologic group and horizon.

The critical value of the standard ANOVA F-test used is approximately 1.94 at the $95 \%$ confidence level (Davis, 2002). The reported F-test value of 7.03 indicates a rejection of the null hypothesis (Table 13). The critical value of the Kruskal-Wallis Chi-squared test used is approximately 16.92 at the $95 \%$ confidence level (Davis, 2002). The Chi-squared value of 40.88 again indicates a rejection of the null hypothesis (Table 14). The results of both tests indicate that at least one group is statistically distinguishable from another. Multiple comparison tests are required in both cases to determine which group or groups are distinct (Figure 19, Figure 20). 
Table 13: A vs B Horizon data ANOVA

\begin{tabular}{|c|c|c|c|c|c|}
\hline Source & $\begin{array}{c}\text { Sum of } \\
\text { Squares }\end{array}$ & $\begin{array}{c}\underline{\text { Degrees of }} \\
\text { Freedom }\end{array}$ & $\begin{array}{c}\underline{\text { Mean }} \\
\text { Squares }\end{array}$ & $\underline{\text { F-Test Value }}$ & $\underline{\text { P-Value }}$ \\
\hline Groups & 608.35 & 9 & 67.59 & 7.03 & $1.89 \times 10^{-8}$ \\
\hline Error & 1441.7 & 150 & 9.61 & & \\
\hline Total & 2050.05 & 159 & & & \\
\hline
\end{tabular}

Table 14: A vs B Horizon Kruskal-Wallis Analysis

\begin{tabular}{|c|c|c|c|c|c|}
\hline$\underline{\text { Source }}$ & $\begin{array}{c}\text { Sum of } \\
\text { Squares }\end{array}$ & $\begin{array}{c}\text { Degrees of } \\
\text { Freedom }\end{array}$ & $\begin{array}{c}\text { Mean } \\
\text { Squares }\end{array}$ & $\begin{array}{c}\underline{\text { Chi-Squared }} \\
\text { Value }\end{array}$ & $\underline{\text { P-Value }}$ \\
\hline Groups & 86160.7 & 9 & 9573.42 & 40.88 & $5.27 \times 10^{-6}$ \\
\hline Error & 248983.8 & 150 & 1659.89 & & \\
\hline Total & 335144.5 & 159 & & & \\
\hline
\end{tabular}

The standard ANOVA multiple comparison test indicates that the A horizon $M S$ group is distinct from group $Q B$ in the $A$ and $B$ horizon. In the $B$ horizon, the $M S$ group is distinct from all other tested groups (Figure 19). The Kruskal-Wallis multiple indicates that the MS group is distinct from group $Q B$ in the $A$ and $B$ horizon. In the $B$ horizon, the MS group is distinct from groups $Q B, Q T S$, and VS in both the $A$ and $B$ horizons (Figure 20). These results are consistent with the previously discussed standard ANOVA and Kruskal-Wallis test. Group MS is shown to be distinct from other lithologic groups.

The lack of statistically significant distinguishability between A and B horizon data is most likely due to the young age of many of the soils tested (Burns et al., 1991; Birkeland, 1999). In this dataset, 31 of the high values at a given site would not have been detected if only A horizon soils were sampled. 


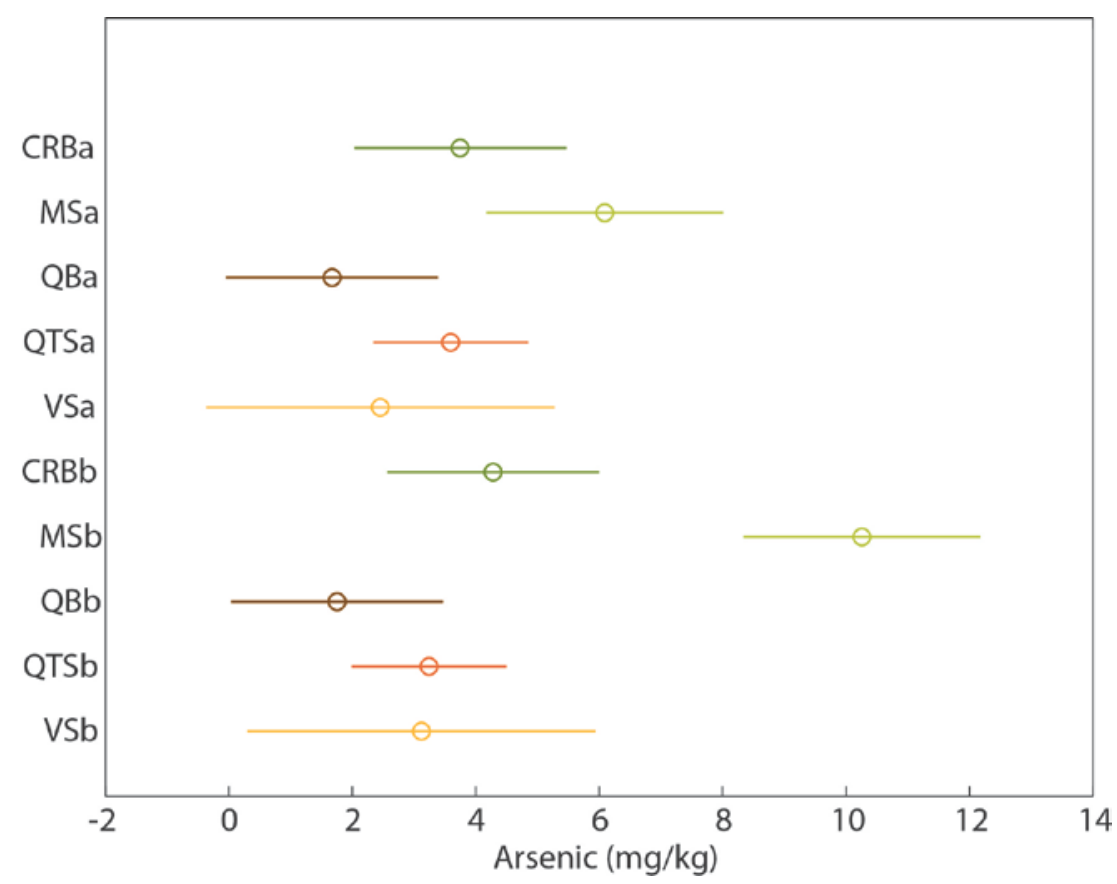

Figure 19: The standard ANOVA multiple comparison test indicates that group MS in the $A$ horizon is distinct from group QB in the $A$ and $B$ horizon. Group MS in the $B$ horizon is distinct from all other tested groups.

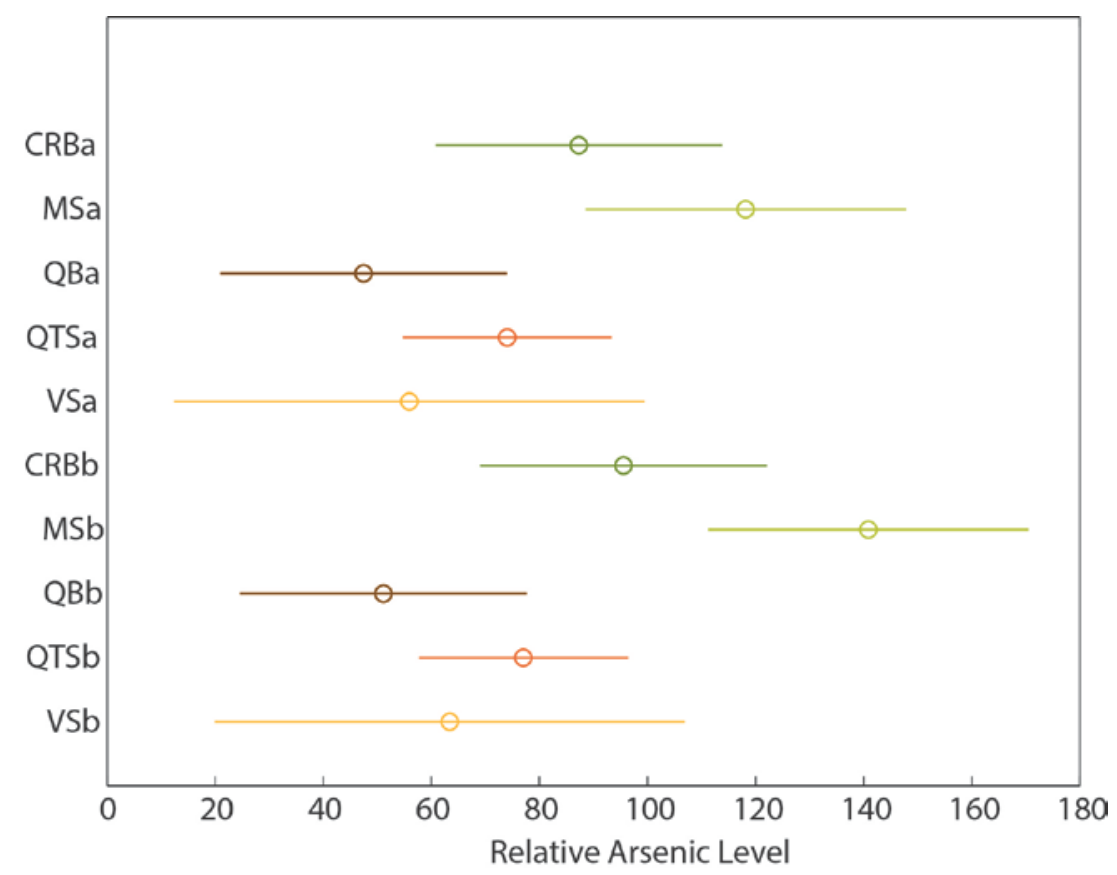

Figure 20: The Kruskal-Wallis multiple comparison test indicates group MS in the $A$ horizon is distinct from group QB in both the $A$ and $B$ horizon. Group MS in the B horizon is distinct from groups QB, QTS and VS in the A and B horizons. 


\section{5: K-MEANS CLUSTER ANALYSIS}

\subsection{1: RATIONALE}

Cluster analysis is a procedure for grouping data so that members of a given group are more similar to each other than they are to members of other groups. A centroid-based approach called K-means clustering, in which $\mathrm{K}$ represents the number of groups, is used here (Davis, 2002; Mathworks, 2012a). The resulting groups can be used for additional analyses, and in this case will be used to test the motivating hypothesis that soil arsenic content reflects underlying bedrock geology. If the hypothesis is correct, clusters will be comprised of samples with similar underlying bedrock lithologies. If this hypothesis is true for these soils, the bedrock type underlying the soil might then be used as an indicator of the background level of arsenic in soil.

\subsection{2: METHOD}

This clustering method is iterative and begins with the identification of centroids around which individual data points are grouped. The means of these groups are calculated and used to identify new centroids which better fit the data and new groupings are assigned. The process is repeated until individual data points remain assigned to the same group throughout subsequent iterations. A K-means clustering algorithm in the Statistics Toolbox of Matlab software is used in this analysis (Mathworks, 2012a). Three, four and five group cluster analyses are presented here. Calculations with $\mathrm{K}$ values greater than 5 did not converge. 
The ratio of normalized $A$ and $B$ horizon arsenic values was used to identify clusters. Natural arsenic may accumulate in soils as they age, a process that, if occurring, will be reflected across the soil profile. This accumulation first occurs through leaching processes as bedrock degrades into soils. In later stages of soil development, this accumulation occurs as A and B horizons become well-developed and water and other weathering processes leach elements from the $A$ to $B$ horizon as the soil ages (Burns et al., 1991). Using the A to B horizon ratio allows soils of different ages to be compared. The arsenic concentrations are normalized to the maximum arsenic concentration measured in the respective horizon so that data from different soil pits can be treated as one dataset.

The quality of the groups formed by the cluster analysis is determined by comparing individual arsenic values to the mean of their assigned group. This comparison is shown graphically as a silhouette graph of the goodness of fit of each sample in its assigned cluster (Figure 22, Figure 24, Figure 26). Points with silhouette values approaching 1 are strong members of their assigned cluster, while points with a negative silhouette value are poor members of their assigned cluster (but do not fit elsewhere). The quality of the cluster analysis is determined by the mean of these silhouette values, with means closer to 1 indicating strong clusters, distinct from each other. 


\subsection{3: RESULTS}

The three group cluster analysis yielded the strongest result, though the difference between the three, four and five cluster analyses were small. The three clusters are characterized by 1 ) low arsenic values in the A and B horizons, 2) moderate arsenic values in the A and B horizons, and 3) high arsenic values in either the A or B horizon (Figure 21, Figure 22). The four cluster analysis yields similarly arranged groups, with the low and mid A and B horizon clusters, more or less, separated into three clusters (Figure 23, Figure 24). The five cluster analysis further divides the high $A$ /low $B$ horizon values from the low $A$ /high $B$ horizon values (Figure 25, Figure 26). The mean silhouette values for the three, four and five cluster analysis are $0.6872,0.7116$, and 0.6398 respectively. The negligible difference between the mean silhouette values indicates that the subgroups resulting from the four and five group cluster analysis are not strongly defined. 


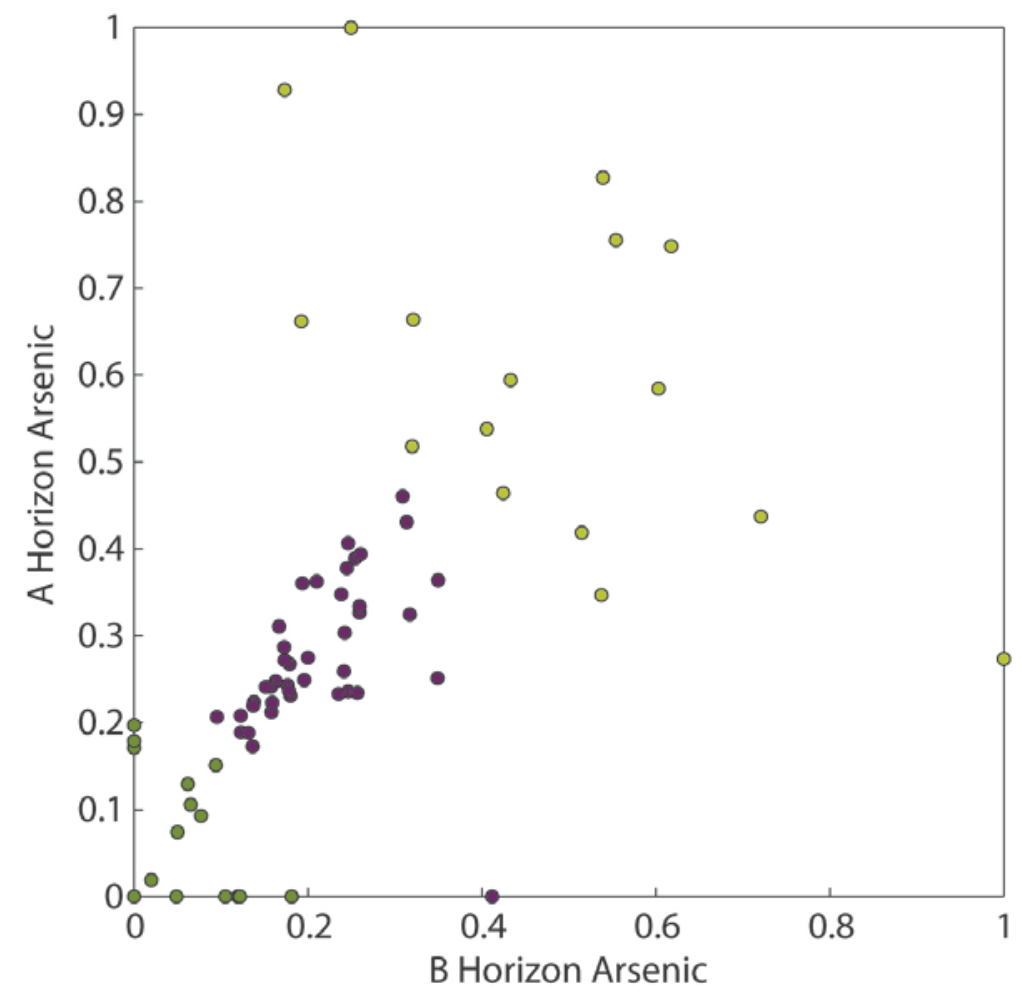

Figure 21: Scatterplot illustrating the results of the three group cluster analysis. Points with common color symbology are assigned to the same cluster.

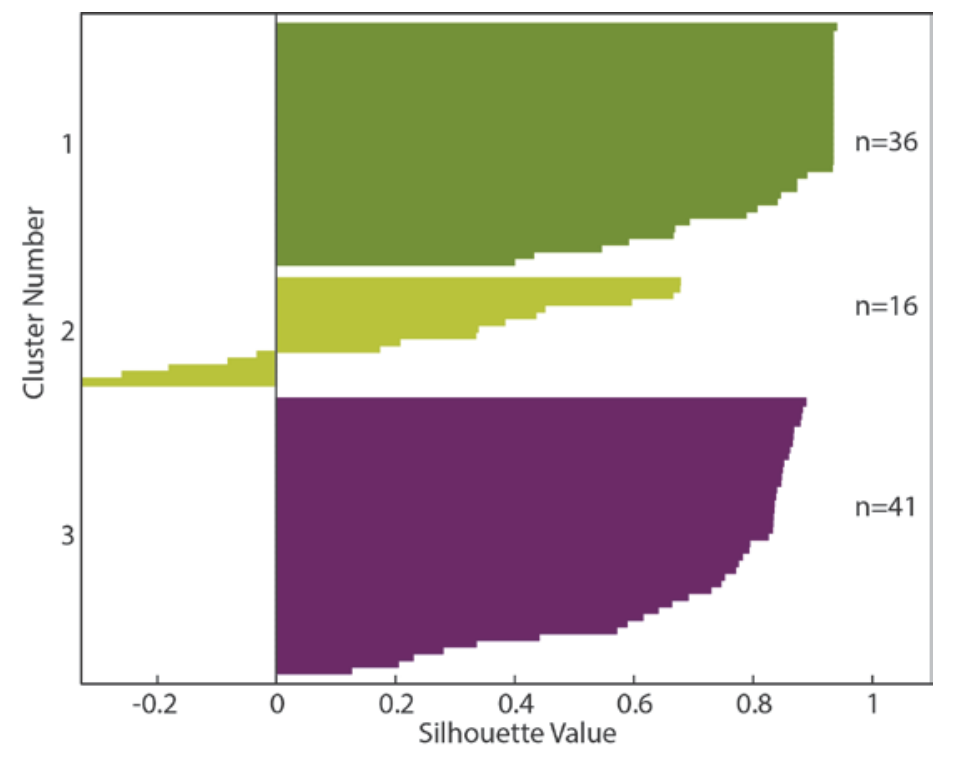

Figure 22: Silhouette graph illustrating the strength of the three cluster analysis results.

Color symbology represents cluster. Color of groups in Figure $\mathbf{2 2}$ match groups in Figure 21. 


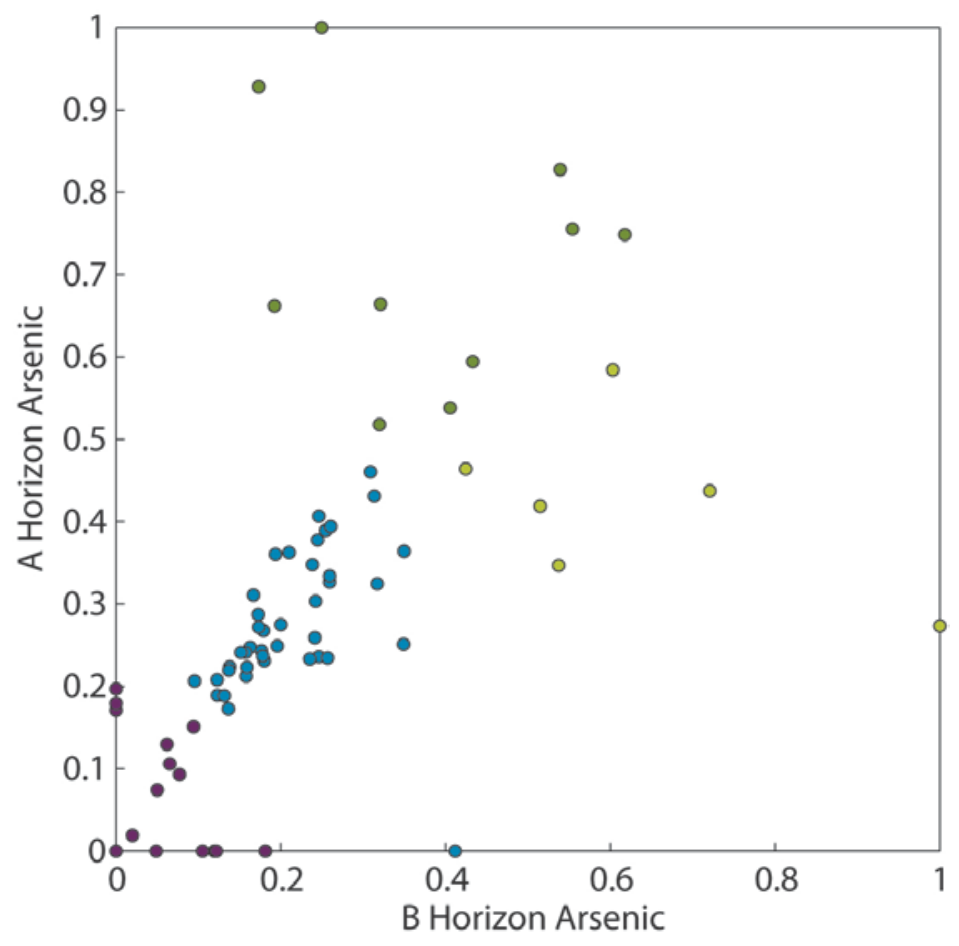

Figure 23: Scatterplot illustrating the results of the four group cluster analysis. Points with common color symbology are assigned to the same cluster.

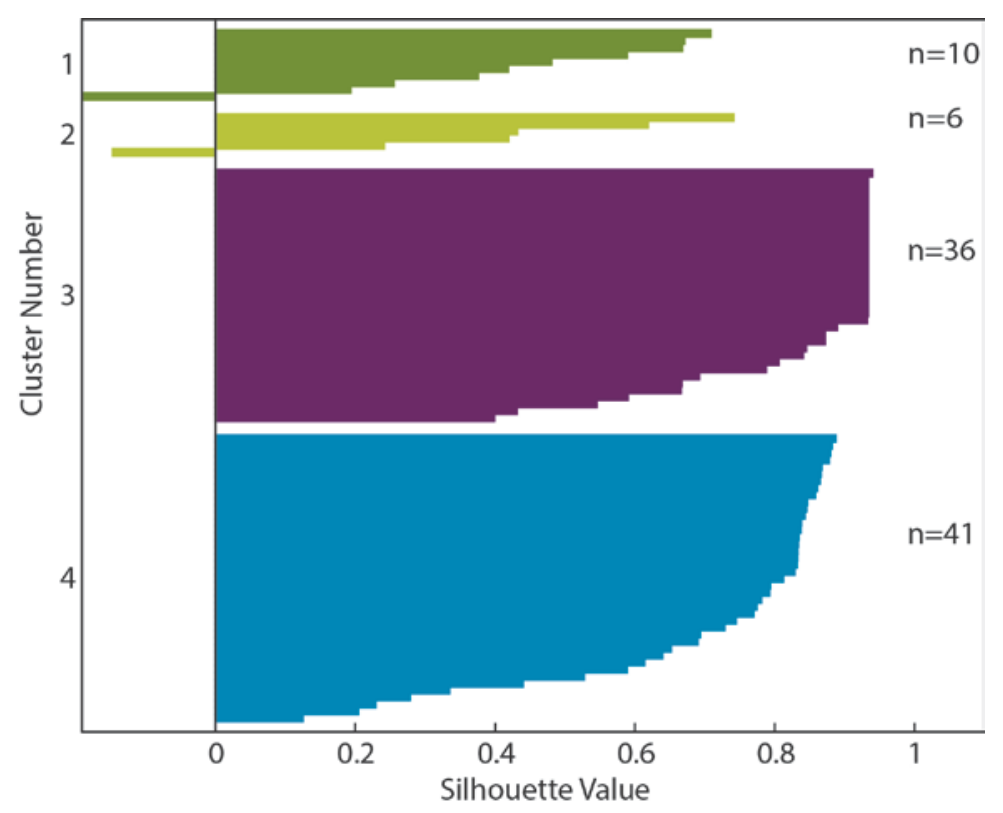

Figure 24: Silhouette graph illustrating the strength of the four cluster analysis results.

Color symbology represents cluster. Color of groups in Figure $\mathbf{2 4}$ match groups in Figure 23. 


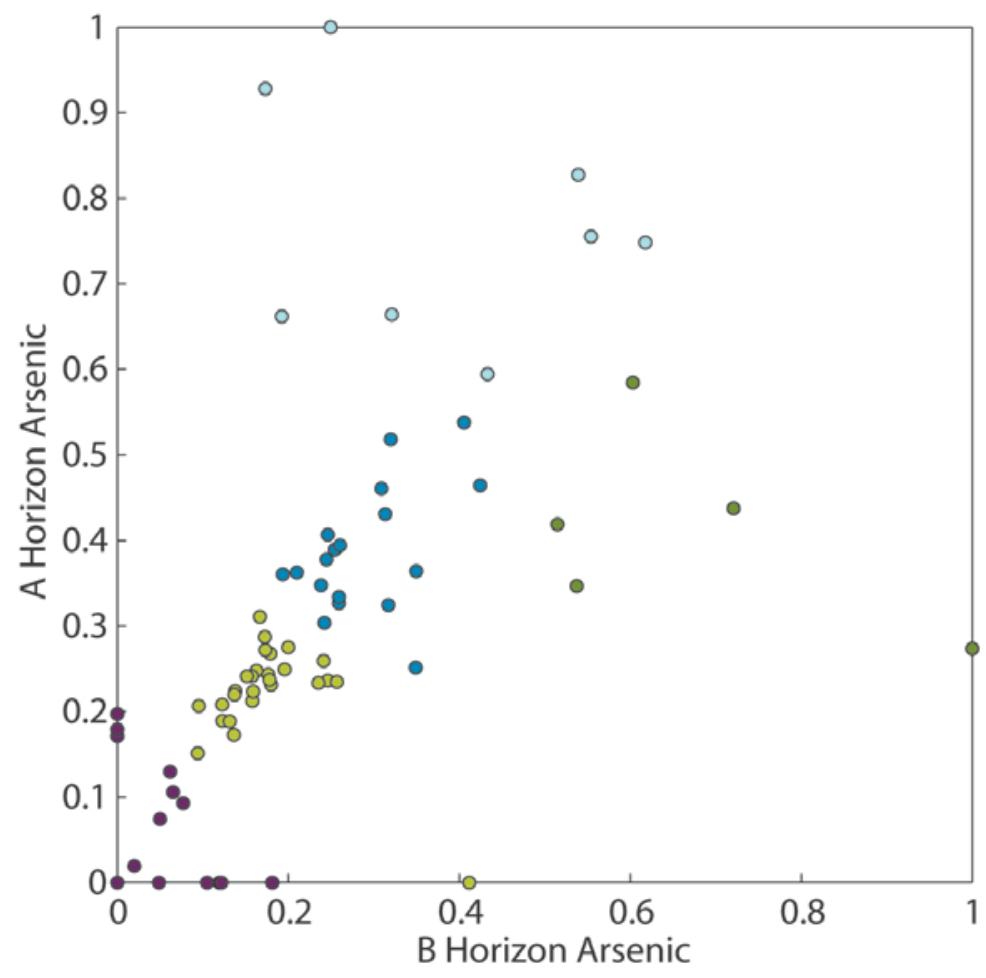

Figure 25: Scatterplot illustrating the results of the five group cluster analysis. Points with common color symbology are assigned to the same cluster.

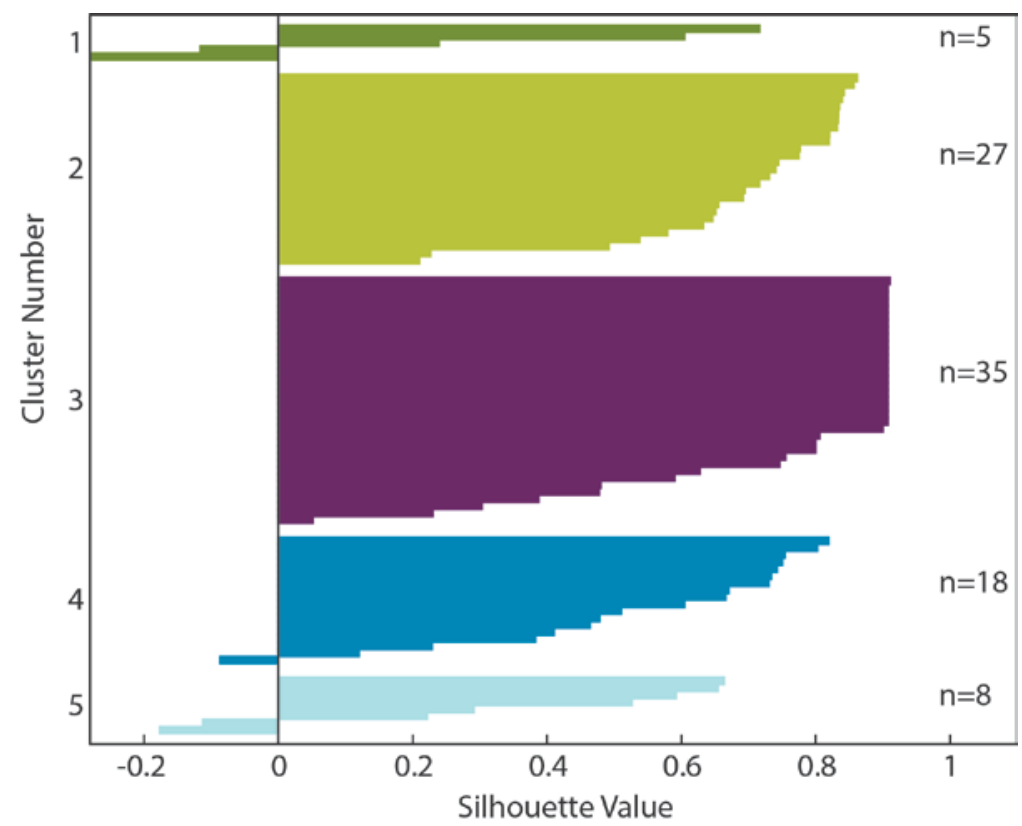

Figure 26: Silhouette graph illustrating the strength of the five cluster analysis results.

Color symbology represents cluster. Color of groups in Figure $\mathbf{2 6}$ match groups in Figure 25. 
The hypothesis motivating the creation of a background soil arsenic map is tested by comparing the results of the cluster analyses with the lithologic groups discussed in the Methods section of this report and Table 3. To do this, the samples in each lithologic group are coded by color based on assigned cluster (Figure 27, Figure 28, Figure 29). For this analysis, lithologic group size is not a consideration, and all nine lithologic groups are included. In no case is a lithologic group strongly associated with a specific cluster, the exception being the lithologic groups comprised of low sample numbers such as the Andesite group. When the number of samples in a lithologic group rises, for example the Columbia River Basalt or Quaternary/ Tertiary Sediment groups, the samples from these lithologic groups are distributed into multiple clusters. 


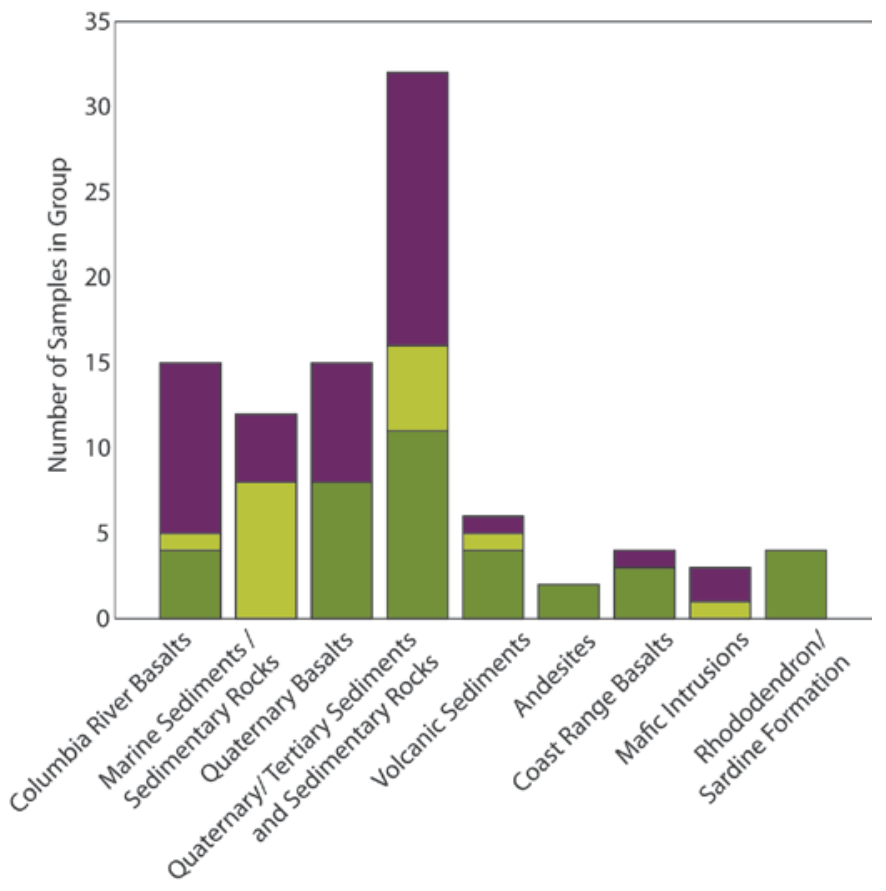

Figure 27: Bar graph connecting lithologic groups (X-axis) to the groups resulting from the three group cluster analysis (color symbology). Color symbology reflects clusters noted in Figure $\mathbf{2 1}$ and Figure 22.

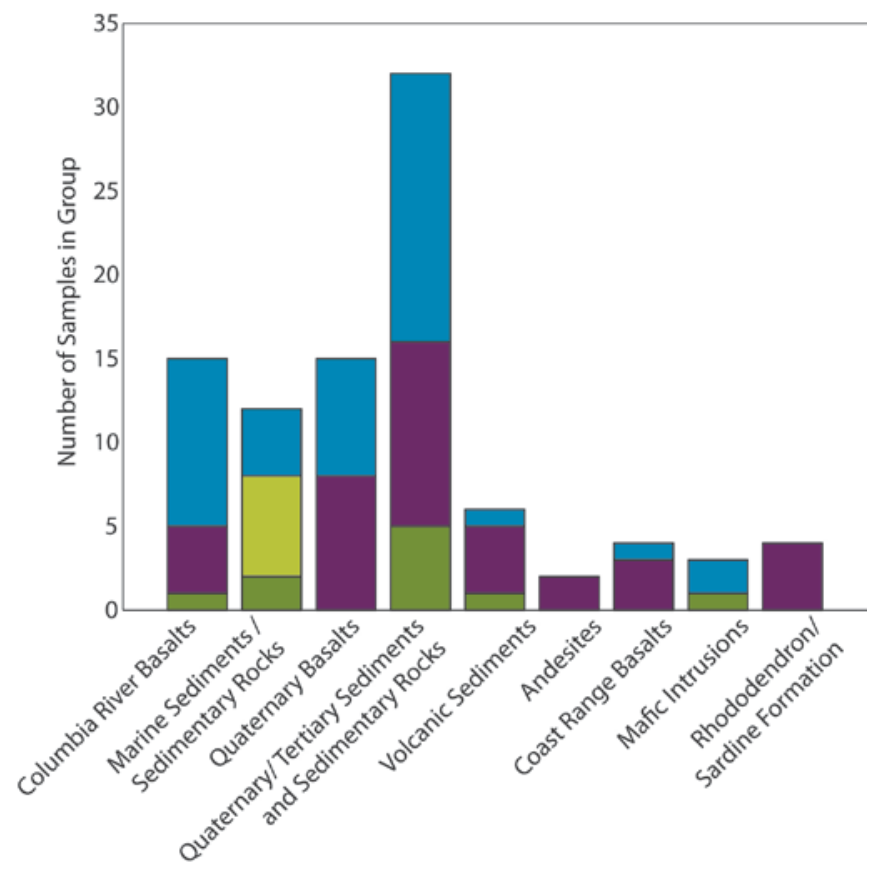

Figure 28: Bar graph connecting lithologic groups (X-axis) to the groups resulting from the four group cluster analysis (color symbology). Color symbology reflects clusters noted in Figure 23 and Figure 24. 


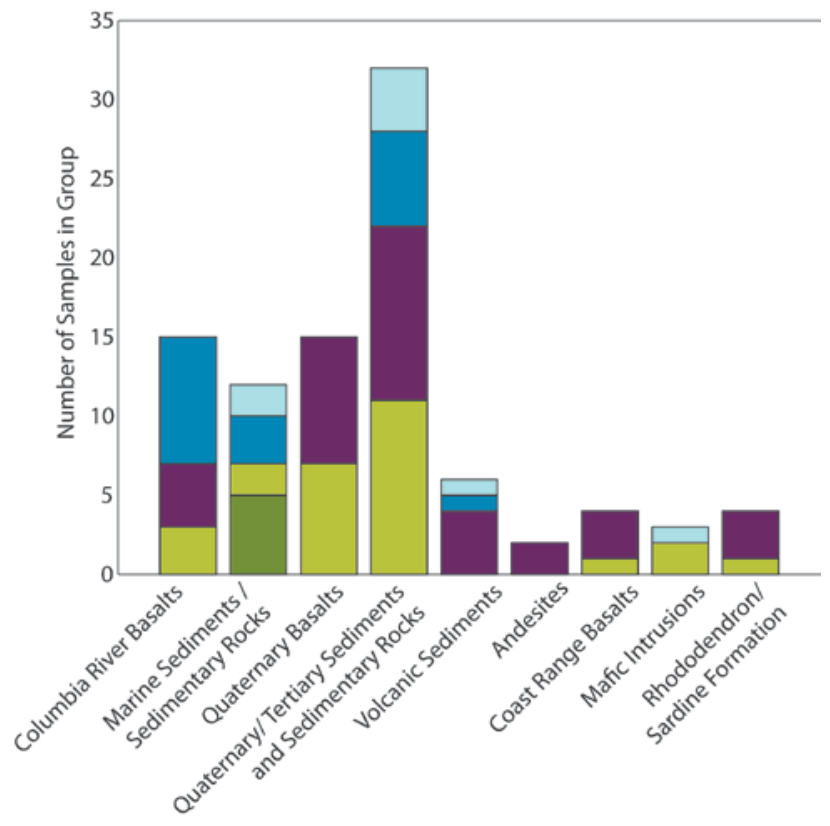

Figure 29: Bar graph connecting lithologic groups (X-axis) to the groups resulting from the five group cluster analysis (color symbology). Color symbology reflects clusters noted in Figure $\mathbf{2 5}$ and Figure 26. 


\section{CHAPTER 6: DISCUSSION AND CONCLUSIONS}

For this project, $186 \mathrm{~A}$ and $\mathrm{B}$ horizon soil samples collected from 93 sites were tested for arsenic. Inductively Coupled Plasma Mass Spectrometry was used with a detection limit for arsenic of .01 ppm (Personal communication, David Jack, Apex Labs, October 2012). Soil pits that were sampled are above 31 geologic units per Walker and MacLeod's (1991) geologic map of Oregon. The resulting data are

presented in Appendix J: Soil Arsenic Data from Northwest Oregon. A comprehensive outline linking the desired goals stated in the introduction of this project to their outcomes as illustrated by the tables and graphs included in this work is provided in Appendix L: Outline Illustrating Outcomes of Stated Goals.

High and low values measured and number of samples not registering values are grouped by geologic unit, presented by horizon, and seen in Appendix K: High and Low Values for Samples by Mapping Unit. The highest value measured in the A horizon is $13.90 \mathrm{ppm}$ at site P4. These soils overly geologic unit Qs, Missoula Flood sediments, and are part of the Quaternary/ Tertiary Sediments and Sedimentary Rocks lithologic group. In the B horizon, the highest value measured is $20.4 \mathrm{ppm}$ at site C4. This soil overlies geologic unit Tmst and is part of the Marine Sediments and Sedimentary Rocks lithologic group. Twenty-eight A horizon samples and 23 B horizon samples had unmeasurable amounts of arsenic. 


\section{1: CONCLUSIONS}

The statistical analysis completed for this project indicates that soils sampled from above the Marine Sediments and Sedimentary Rocks (MS) group have statistically distinguishable, and higher, arsenic levels when compared to other lithologic groups (Table 12). These groups are shown to be distinct from each other based on the standard ANOVA and Kruskal-Wallis tests comparing the data by lithologic group both within and between each soil horizon. The mean arsenic levels of the MS group soils are $6.09 \pm 2.66 \mathrm{ppm}$ in the A horizon and $10.26 \pm 4.65$ in the $B$ horizon. The other groups tested were not distinct from each other and were therefore grouped together. This group has mean arsenic levels of $3.10 \pm 3.19 \mathrm{ppm}$ in the A horizon and $3.13 \pm 2.52 \mathrm{ppm}$ in the B horizon.

Testing the A and B horizon soils for arsenic should be done for two reasons: first, to find the highest amount of arsenic within the horizons of the soil profile, and second, to characterize the variable distribution of arsenic throughout the vertical extent of the soil profile. When the A horizon and B horizon data analyzed for this project were compared to each other by lithologic group, the only groups that were statistically distinct were MS group values in the A and B horizon. In no other case were A and B horizon data statistically distinguishable from each other (5.4: A VS B HORIZON ANALYSIS). According to Burns et al. (1991), the level of arsenic in B horizon soils is expected to be higher in well developed soils. In many cases, the A horizon values of the soils tested for this project may be higher because they are young soils (Burns et al., 1991; Birkeland, 1999). Because neither the A nor B horizon 
samples tested for this project had statistically higher levels of arsenic, both horizons had to be tested to find the higher tested arsenic value. This demonstrates that surface sampling only may not accurately represent the soil, and both horizons should be sampled.

The specific reasons why there are comparatively elevated arsenic levels seen in soils above MS group units are beyond the scope of this project. However, this elevated arsenic content could be linked to both the prevalence of arsenic-linked minerals in these units and this lithologic group including formations that are known to be associated with elevated arsenic levels (eg., the Fisher and Eugene Formations). It is noteworthy that these results are consistent with the bedrock arsenic data of Onishi and Sandell (1955), Boyle and Jonasson (1973) and Mandal and Suzuki (2001) (Appendix B: Overview of Arsenic Content by Rock). Their work indicates that higher amounts of arsenic are commonly found in sedimentary rocks compared to igneous rocks. The MS lithologic group exemplifies the sedimentary rock types listed in Appendix B: Overview of Arsenic Content by Rock, while the other tested groups are volcanic in origin and exemplify igneous rock types listed in Appendix B: Overview of Arsenic Content by Rock.

The MS group includes the previously mentioned Fisher and Eugene Formations, both known to be associated with elevated arsenic levels (Hinkle and Polette, 1999). This association is apparent in the relatively high amounts of arsenic found in the aquifers underlying these units (Hinkle and Polette, 1999). The origin of the elevated arsenic content associated with these formations is environmental and 
may be linked to mineralogy of these rocks. For example, many of these rocks contain micas and these formations also include tuff units (Walker and MacLeod, 1991).

The MS group also includes significant amounts of additional tuffaceous sedimentary rock units. These rocks, formed primarily from the sediments of silicic volcanics, are known to be linked with high arsenic content (Hinkle and Polette, 1999).

The Scappoose Formation in the Coast Range Province is included in the MS group. This formation is known to be highly micaceous; this mineralogy provides a connection between the sediments of this formation and the Idaho Batholith from which its sediments are weathered (Orr and Orr, 1999). Weathered micas are known to be associated with elevated levels of naturally occurring arsenic (Dowling et al., 2002). The presence of elevated arsenic in Scappoose Formation rocks and their overlying soils would be consistent with the mineralogy of this Formation.

In the Bengal Basin, organic matter is believed to play an important role in the dangerous levels of naturally occurring arsenic found in the groundwater there (Ahmed et al., 2006). This elevated organic content may also play a role in the arsenic content of MS group soils, as rock types deposited in the marine environment are generally enriched in organic content.

This project has implications for establishing the background level of arsenic in soils. The arsenic content of soils is affected by geologic setting, as illustrated by the statistically distinguishable, and higher, levels of arsenic in soils above MS group 
lithologies (Table 12). Currently, the Oregon DEQ has one background level for naturally occurring arsenic in soils for the entire state. That the soils of the MS group are shown to be distinct from the other groups that were tested indicates this single value for a large geographic area may not be appropriate. The background levels of arsenic in soils may vary within a region and should be determined within a geologic context.

\section{2: FUTURE WORK}

A review of Appendix J: Soil Arsenic Data from Northwest Oregon suggests that the soil samples taken from above Unit Tus in the Cascades exhibit unexpectedly high arsenic values based on rock type and location. Many of the soils in this area exhibited relatively low or non-detectable amounts of arsenic. The two soil samples taken from above Unit Tus tested $4.22 \mathrm{ppm}$ and $4.94 \mathrm{ppm}$ in the A horizon, values which are higher than the mean of the MS group in the A horizon. In the B horizon, these pits measured $10.50 \mathrm{ppm}$ and $11.30 \mathrm{ppm}$, again values that are higher than the mean of the MS group data in the B horizon. Further testing of the soils above this unit is required to ascertain if these values are representative of the soils from above this geologic unit and, if so, why these values are comparatively high.

A particularly interesting characteristic of the scatterplots (Figure 21, Figure 23, Figure 25) generated for the K-Means Cluster Analysis included in this project is the generally linear nature of the A vs B horizon arsenic values for sites, where $A$ and B horizon normalized arsenic values are lower than 0.6. At these relatively low 
arsenic levels, the normalized A and B horizon arsenic values at a given site are very close to each other. When either horizon's normalized arsenic value is above this normalized 0.6 value, no apparent correlation between $A$ and $B$ horizon arsenic content is apparent at these sites. Future work would explore this observation to determine if this characteristic is true for other soil arsenic datasets. If so, further study would also ascertain why arsenic in A and B horizon soils at a given site are close to each other when arsenic content is low and more disparate at higher arsenic values.

In future studies, additional sampling where multiple samples are taken from multiple pits will allow additional statistical tests to be run. This type of dataset will also allow for a greater understanding of variability both within a single pit and between pits dug over the same bedrock lithology. A greater understanding of within pit variability would allow for outliers to be identified and managed, as well as a constraint of standard deviations. This type of additional sampling will additionally provide information on arsenic transport and host phase associations in soil profiles..

Additional work on this project would continue to explore the control of bedrock on soil arsenic levels. Statistics would be used to further ascertain the connection between bedrock and arsenic content. Exploring these controls would entail a more constrained sampling approach where samples would be taken from a smaller geographic area and from above a smaller number of geologic units. Sampling from above units that are distinct lithologically would ensure that if arsenic 
content of soils are not distinguishable based on underlying bedrock, that result is not due to the rock types being overly similar to each other.

In addition to exploring the connection between bedrock and the arsenic content of overlying soils, additional types of data would be collected to explore the effects of these other environmental factors on arsenic content. These additional types of data include $\mathrm{pH}$, age, moisture content, and grain size. Additional data on $\mathrm{pH}$ would ascertain how this environmental factor is affecting the arsenic values measured. This type of data would also help constrain how $\mathrm{pH}$ needs to be considered during environmental assessments and other studies. Additional data on soil age and developmental stage would illuminate how arsenic levels vary by horizon in a soil depending on age, and could possibly illuminate important information regarding ratios of $A$ to $B$ horizon soil arsenic. 


\section{REFERENCES}

Addicott, W.O., 1976, Neogene molluscan stages of Oregon and Washington, in Wornardt, W.W., ed., Symposium of the Neogene of the Pacific Coast: Society of Economic Paleontologists and Mineralogists, Pacific Section, San Francisco, California, April 1976, p. 95-115.

Addicott, W.O., 1981, Significance of Pectinids in the Tertiary biochronology of the Pacific Northwest, in Armentrout, J.M., ed., Pacific Northwest Cenozoic Biostratigraphy: Geological Society of America Special Paper 184, p. 17-37.

Ahmed, K.M., Imamul Huq, S.M., and Naidu, R., 2006, Chapter 31: Extent and severity of arsenic poisoning in Bangladesh, in Naidu, R., Smith, E., Owens, G., Bhattacharya, P. and Nadebaum, P., eds., Managing Arsenic in the Environment: From Soil to Human Health, CSIRO Publishing, p. 525-540.

Allen, J.L., Burns, M., Burns, S., 2009, Cataclysms on the Columbia: The Great Missoula Floods, Ooligan Press, $2^{\text {nd }}$ ed., 216 p.

Armentrout, J.M., 1981, Correlation and ages of Cenozoic chronostratigraphic units in Oregon and Washington, in Armentrout, J.M., ed., Pacific Northwest Cenozoic Biostratigraphy: Geological Society of America Special Paper 184, p. 137-148.

Ashbaugh, S., 1995. The Distribution of naturally occurring radionuclides and radon Potential of Northwest Oregon. Masters Thesis, Portland State University.

Baldwin, E.M., 1974, Eocene Stratigraphy of Southwestern Oregon: Oregon Department of Geology and Mineral Industries Bulletin 83, 40 p.

Basta, N.T., Rodriguez, R.R., Casteel, S.W., 2002, Bioavailability and risk of arsenic exposure by the soil ingestion pathway, in Frankenberger, Jr., W.T. ed., Environmental Chemistry of Arsenic, Marcel Decker: New York, NY, 391 p.

Beaulieu, J.D., and Hughes, P.W., 1975, Environmental Geology of Western Coos and Douglas Counties, Oregon: Oregon Department of Geology and Mineral Industries, Bulletin 87, 148 p., scale 1:62,500. 
Bela, J.L., 1981, Geology of the Rickreall, Salem West, Monmouth, and Sidney 7-1/2' Quadrangles, Marion, Polk and Linn Counties, Oregon: Oregon Department of Geology and Mineral Industries Geologic Map Series GMS-18, scale 1:24,000.

Birkeland, P. W., 1999, Soils and Geomorphology, $3^{\text {rd }}$ ed.: Oxford, Oxford University Press, $430 \mathrm{p}$.

Boschmann, D.E., 2008. Distribution of Naturally Occurring Heavy Metals and Trace Elements in Soils of Northwest Oregon. Poster, Portland State University.

Bowen, R.G., Gray, W.L., and Gregory, D.C., 1963, General geology of the northern Juntura Basin, in Shotwell, J.A., et al., eds., The Juntura Basin: Studies in Earth History and Paleoecology: Transactions of the American Philosophical Society, New Series, v. 53, pt.1, p. 22-34.

Burns, S.F., Thompson, R.H., Beck, J.N. and Meriwether, J.R., 1991, Thorium, uranium and cesium-137 in Louisiana soils: Migration trends in a soil catena near Dubach, Louisiana, USA, Radiochimica Acta 52/53, p. 241-247.

Boyle, R.W. and Jonasson, I.R., 1973, The geochemistry of arsenic and its use as an indicator element in geochemical prospecting, Journal of Geochemical Exploration, v. 2, p. 251-296.

Corcoran, R.W., Doak, R.A., Porter, P.W., Pritchett, F.I., and Privasky, N.C., 1962, Geology of the Michell Butte Quadrangle, Oregon: Oregon Department of Geology and Mineral Industries, Geologic Map Series GMS-2, scale 1:125,000.

Davis, J.C., 2002, Statistics and Data Analysis in Geology, Wiley, $3^{\text {rd }}$ ed., 656 p.

Dowling, C.B., Poreda, R.J., Basu, A.R., Peters, S.L. and Aggarwal, P.K., 2002, Geochemical study of arsenic release mechanisms in the Begal Basin groundwater, Water Resources Research, v. 38, 1173, 18 p.

Duncan, R.A., 1982, A captured island chain in the Coast Range of Oregon and Washington: Journal of Geophysical Research, v. 87, no. B-13, p. 10,82710,837 .

EPA, 2007, Environmental Protection Agency Method 6020A: Inductively coupled plasma mass spectrometry. http://www.epa.gov/osw/hazard/testmethods/sw846/pdfs/6020a.pdf 
EPA, 2012, Regional Screening Levels (Formerly PRGs): Screening Levels for Chemical Contaminants.

http://www.epa.gov/region9/superfund/prg/

User's Guide: http://www.epa.gov/reg3hwmd/risk/human/rb-

concentration table/usersguide.htm

Regional Screening Level (RSL) Summary Table, April 2012,

http://www.epa.gov/reg3hwmd/risk/human/rb-

concentration table/Generic Tables/pdf/master sl table run MAY2012.pdf

Eubanks, W., 1960, Fossil woods of the Thomas Creek area, Linn County, Oregon:

The Ore Bin, v. 22, no. 7, p. 65-69.

Evernden, J.J.F. and James, G.T., 1964, Potassium-argon dates and the Tertiary floras of North America: American Journal of Science, v. 262, p. 945-974.

Flint, R.F., 1938, Origin of the Cheney-Palouse scabland tract, Washington: Geological Society of America Bulletin, v. 49, no. 3, p. 461-523.

Fiebelkorn, R.B., Walker, G.W., Macleod, N.S., McKee, E.H., and Smith, J.G., 1983, Index to K-Ar age determinations for the State of Oregon: Isochron/West, no. $37,60 \mathrm{p}$.

Francesconi, K.A. and Kuehnelt, D., 2002, Arsenic compounds in the environment, in Frankenberger, Jr., W.T., ed., Environmental Chemistry of Arsenic, Marcel Decker: New York, NY, 391 p.

Goldberg, S., 2002, Competitive Adsorption of Arsenate and Arsenite on Oxides and Clay Minerals, Soil Science Society of America Journal, v. 66, p. 413-421.

Gullixson, C.F., 2006, Geology Technical Report Wildwood - Wemme Project, Oregon Department of Transportation.

Hampton, E.R., 1964, Geologic factors that control the occurrence and availability of ground water in the Fort Rock Basin, Lake County, Oregon: U.S. Geological Survey Professional Paper 383-B, p. B2-B29.

Hampton, E.R., 1972, Geology and Groundwater of the Molalla-Salem Slope Area, Northern Willamette Valley, Oregon: U.S. Geological Survey Water-Supply Paper 1997, 83 p. 
Hammond, P.E., Geyer, K.M., and Anderson, J.L., 1982, Preliminary Geologic Map and Cross Sections of the Upper Clackamas and North Santiam Rivers Area, Northern Oregon Cascade Range: Portland State University Department of Earth Sciences, Portland, Oregon, scale, 1:62,500.

Heller, P.L., Peterman, Z.E., O’Neil, J.R., and Shafiqullah, M., 1985, Isotopic provenance of sandstones of the Eocene Tyee Formation, Oregon Coast Range: Geological Society of America Bulletin, v. 96, p. 770-780.

Hinkle, S.R. and Polette, D.J., 1999, Arsenic in Ground Water of the Willamette Basin, Oregon, United States Geological Survey Water-Resources Investigations Report 98-4205, 34 p.

Hogenson, G.M., 1964, Geology and Ground Water of the Umatilla River Basin, Oregon: U.S. Geological Survey Water-Supply Paper 1620, 162 p.

Hughes, M.F., 2002, Arsenic toxicity and potential mechanisms of action, Toxicology Letters, v. 133, no. 1, p. 1-16.

IPCS, 2001, Arsenic and arsenic compounds. Geneva, World Health Organization, International Programme on Chemical Safety: Environmental Health Criteria 224, $114 \mathrm{p}$.

Kittleman, L.R., Green, A.R., Hagood, A.R., Hohnson, A.M., McMurray, J.M., Russell, R.G., and Weeden, D.A., 1965, Cenozoic Stratigraphy of the Owyhee Region, Southeastern Oregon: University of Oregon, Museum of Natural History Bulletin, 1, $45 \mathrm{p}$.

Kleinpell, R.M., 1938, Miocene Stratigraphy of California: Tulsa, Oklahoma, American Association of Petroleum Geologists, 450 p.

Krauskopf, K.B., and Bird, D.K., 1995, Introduction to Geochemistry $3^{\text {rd }}$ ed., McGrawHill, Inc., 647 p.

Lux, D.R., 1982, K-Ar and ${ }^{40} \mathrm{Ar}^{30}$ ages of mid-Tertiary volcanic rocks from the Western Cascade Range, Oregon: Isochron/West, no. 33, p. 27-32.

MacLeod, N.S., 1981, Differentiation of a Gabbro Sill in the Orgon Coast Range by Crystallization-zone Settling: U.S. Geological Survey Professional Paper 1165, $22 \mathrm{p}$. 
Magill, J., Cox, A. and Duncan, R., 1981, Tillamook volcanic series- further evidence for tectonic rotation of the Oregon Coast Range: Journal of Geophysical Research, v. 86, no. B4, p. 2953-2970.

Mallory V.S., 1959, Lower Tertiary Biostratigraphy of the California Coast Ranges: Tulsa, Oklahoma, American Association of Petroleum Geologists, 416 p.

Mandal, B.K., and Suzuki,K.T., 2002, Arsenic round the world: A review, Talanta, v. 58: p. 201-235.

Manning, B.A. and Goldberg, S., 1997, Adsorption and stability of arsenic (III) at the clay mineral-water interface, Environmental Science Technology, v. 31, p. 2005-2011.

Mason, B.J., 2002, Environmental Protection Agency: Preparation of Soil Sampling Protocols: Sampling Techniques and Strategies, 169 pgs. http://www.epa.gov/swerust1/cat/mason.pdf.

Mathworks, 2012a, K-Means Clustering, <http://www.mathworks.com/help/stats/kmeans.html>

Mathworks, 2012b, Kruskal-Wallis Test, <http://www.mathworks.com/help/stats/kruskalwallis.html>

Mathworks, 2012c, One-Way Analysis of Variance, <http://www.mathworks.com/help/stats/anova1.html>

McDougall, K., 1975, The microfauna of the type section of the Keasey Formation of northwestern Oregon, in Weaver, D.W., Hornaday, G.R., and Tipton, A., eds., Future Energy Horizons of the Pacific Coast: Society of Economic Paleontologists and Mineralogists, Pacific Section, Long Beach, California, p. 343-359.

McDougall, K., 1980, Paleoecological evaluation of late Eocene biostratigraphic zonations of the Pacific Coast of North America: Society of Economic Paleontologists and Mineralogists, Paleontological Monograph, no. 2, 46 p., $29 \mathrm{pl}$.

McKeel, D.R., 1980, Micropaleontological study of five wells, western Willamette Valley, Oregon: Oregon Department of Geology and Mineral Industries OpenFile Report 0-80-1, $21 \mathrm{p}$. 
McLaren, R.G., Megharaj, M. and Naidu, R., 2006, Chapter 8: Fate of arsenic in the soil environment, in Naidu, R., Smith, E., Owens, G., Bhattacharya, P. and Nadebaum, P., eds., Managing Arsenic in the Environment: From Soil to Human Health, CSIRO Publishing, p. 157-182.

Miller, P.R., and Orr, W.N., 1984, Geologic Map of the Wilhoit Quadrangle, Oregon: Oregon Department of Geology and Mineral Industries Geologic Map Series GMS-32, scale 1:24,000.

Misra, K.C., 2012, Introduction to Geochemistry, Wiley-Blackwell, 456 p.

Montana Department of Environmental Quality Remediation Division, 2005, Action Level for Arsenic in Surface Soil, http://deq.mt.gov/StateSuperfund/PDFs/ArsenicPositionPaper.pdf. and http://deq.mt.gov/StateSuperfund/frequentlyaskedquestions.mcpx

Naidu, R., and Bhattacharya, P., 2006, Chapter 18: Management and remediation of arsenic from contaminated water, in Naidu, R., Smith, E., Owens, G., Bhattacharya, P. and Nadebaum, P., eds., Managing Arsenic in the Environment: From Soil to Human Health, CSIRO Publishing, p. 157-182.

NASA, Global Change Master Directory, 10/3/2012, Northwest Physiographic Provinces, http://gcmd.nasa.gov/records/GCMD nwfphypro.html.

Newcomb, R.C., 1965, Geology and Ground-water Resources of the Walla Walla River Basin, Washington-Oregon: Washington Division of Water Resources Water Supply Bulletin, no. 21, 151 p.

Newcomb, R.C., 1966, Lithology and Eastward Extension of the Dalles Formation, Oregon and Washington, in Geological Survey Research 1966: U.S. Geological Survey Professional Paper 550-D, p. D59-D63.

Newcomb, R.C., 1969, Effect of tectonic structure of the occurrence of ground water in the basalt of the Columbia River Group of The Dalles area, Oregon and Washington: U.S. Geological Survey Professional Paper 383-C, p. C1-C33.

Newton, V.C. and Van Atta, R.O., 1976, Prospects for Natural Gas Production and Underground Storage of Pipe-line Gas in the Upper Nehalem River Basin, Columbia-Clatsop Counties, Oregon: Oregon Department of Geology and Mineral Industries, Oil and Gas Investigations 5, 56p., scale 1: 75,000. 
Niem, A.R., and Niem, W.A., 1985, Oil and Gas Investigation of the Astoria Basin, Clatsop and Northernmost Tillamook Counties, Northwest Oregon: Oregon Department of Geology and Mineral Industries, Oil and Gas Investigation OGI14, scale 1: 100,000 .

Nriagu, J.O., Bhattacharya, P., Mukherjee, A.B, Bundschuh J., Zevenhoven, R., and Loeppert, R.H., 2007, Arsenic in soil and groundwater: an overview, Trace Metals and Other Contaminants in the Environment, v. 9, p. 3-60.

Onishi, 1970, Arsenic (33), in Handbook of Geochemistry (ed. Onishi, K.H.) Arsenic, v. 2/II, Springer-Verlag.

Onishi, H., Sandell, E.B., 1955, Geochemistry of arsenic, Geochimica et Cosmochimica Acta, 1955, v. 7, p. 1-33.

Oregon DEQ, 2002, Default background concentrations for metals, Oregon Department of Environmental Quality Toxicology Memo.

Oregon DEQ, 2006, Guidance for Evaluating Residual Pesicides on Lands Formerly Used for Agricultural Production. http://www.deq.state.or.us/lq/pubs/docs/cu/GuidanceEvalResidualPesticides .pdf

Oregon DEQ, 2009, Risk-Based Concentrations for Individual Chemicals. Oregon Department of Environmental Quality, Environmental Cleanup and Tanks Program, 4 p., Rev. Sept. 15, 2009. http://www.deq.state.or.us/lq/pubs/docs/RBDMTable.pdf and http://www.deq.state.or.us/lq/pubs/docs/RBDMSpreadsheetNotes.pdf

Oregon DEQ, 2010, Human Health Risk Assessment Guidance, Oregon Department of Environmental Quality Environmental Cleanup Program. www.deq.state.or.us/lq/pubs/docs/cu/HumanHealthRiskAssessment Guidance.pdf

Orr, E.L. and Orr, W.N., 1999, Geology of Oregon, Kendall Hunt Publishing Co., 254 p.

Peck, D.L., Griggs, A.B., Schlicker, H.G., Well, F.G., and Dole, H.M., 1964, Geology of the Central and Northern Parts of the Western Cascade Range in Oregon: U.S. Geological Survey Professional Paper 449, 56 p.

Piper, A.M., Robinson, T.W., Jr., and Park, C.F., Jr., 1939, Geology and Ground-water Resources of the Harney Basin, Oregon: U.S. Geological Survey Water-Supply Paper 841, $189 \mathrm{p}$. 
Rau, W.W., 1975, Foraminifera and biostratigraphy of the Alsea Formation of western Oregon, Paleogene Symposium: Society of Economic Paleontologists and Mineralogists, Pacific Section, Annual Meeting, Long Beach, California, p. 409416.

Rau, W.W., 1981, Pacific Northwest Tertiary benthic foraminiferal biostratigraphic framework-an overview, in Armentrout, J.M., ed., Pacific Northwest Cenozoic Biostratigraphy: Geologica Society of America Special Paper 184, p. 67-84.

Ricker, T.R. and Shepker, T.J., 2009. Unpublished Report. Arsenic in the Soils and Groundwater of Oregon. Environmental Geology, Portland State University, Fall 2009.

Sadiq, M., 1995, Arsenic chemistry in soils: an overview of thermodynamic predictions and field observations, Water, Air and Soil Pollution, v. 93, p. 117136.

Schlicker, H.G., and Deacon, R.J., 1967, Engineering Geology of the Tualatin Valley Region, Oregon: Oregon Department of Geology and Mineral Industries Bulletin 60, 103 p., scale 1:48,000.

Smith, J.G., 1980, An important lower Oligocene welded-tuff marker bed in the western Cascade Range of southern Oregon: Geological Society of America Abstracts with Programs, v. 12, no. 3, p. 153.

Smith, J.G, Page, N.J., Johnson, M.G, Moring, B.C, and Gray, F., 1982, Preliminary Geologic Map of the Medford $1^{\circ}$ by $2^{\circ}$ Quadrangle, Oregon and California: U.S. Geological Survey Open-File Report 82-955, scale 1:250,000.

Smith, E., Naidu, R. and Alston, A.M., 1999, Chemistry of arsenic in soils: I. sorption of arsenate and arsenite by four Australian soils, Journal of Environmental Quality, v. 28, p. 1719-1726.

Smith, E., Naidu, R., and Alston, A.M., 2002, Chemistry of inorganic arsenic in soils: II. effect of phosphorus, sodium and calcium on arsenic sorption, Journal of Environmental Quality, v. 31, p. 557-563.

Snavely, P.D., Jr., Wagner, H.C., and MacLeod, N.S., 1964, Rhythmic-bedded eugeosynclinal deposits of the Tyee Formation, Oregon Coast Range: Kansas Geological Survey Bulletin 169, v. 2, p. 461-480.

Snavely, P.D., Jr., MacLeod, N.S., and Wagner, H.C., 1968, Tholeiitic and alkalic basalts of the Eocene Siletz River Volcanics, Oregon: American Journal of Science, v. 266, p. 454-481. 
Snavely, P.D., Jr., MacLeod, N.S., and Rau, W.W., 1969, Geology of the Newport area, Oregon: The Ore Bin, v. 31, nos. 2 and 3, p. 25-71.

Snavely, P.D., Jr., MacLeod, N.S., Wagner, H.C., and Rau, W.W., 1976a, Geologic Map of the Cape Foulweather and Euchre Mountain Quadrangles, Lincoln County, Oregon: U.S. Geological Survey Miscellaneous Investigations Series Map I-868, scale $1: 62,500$.

Snavely, P.D., Jr., MacLeod, N.S., Wagner, H.C., and Rau, W.W., 1976b, Geologic Map of the Waldport and Tidewater Quadrangles, Lincoln, Lane, and Benton Counties, Oregon: U.S. Geological Survey Miscellaneous Investigations Series Map I-866, scale 1:62,500.

Sutter, J.F., 1978, K-Ar ages of Cenozoic volcanic rocks from the Oregon Cascades west of $121^{\circ} 30^{\prime}$ : Isochron/West, no. 21, p. 15-21.

Swanson , D.A., Wright, T.L., Hooper, P.R., and Bentley, R.D., 1979, Revisions in stratigraphic nomenclature of the Columbia River Basalt Group: U.S. Geological Survey Bulletin 1457-G, p. G1-G59.

Swanson, D.A., Anderson, J.L, Camp, V.E., Hooper, P.R., Taubeneck, W.H., and Wright, T.L., 1981, Reconnaissance Geologic Map of the Columbia River Basalt Group, Northern Oregon and Western Idaho: U.S. Geological Survey, Open-File Report 81-797, 33 p., scale 1:250,000.

Tanaka, T., 1988, Distribution of arsenic in the natural environment with emphasis on rocks and soils, Applied Organometallic Chemistry, v. 2, p. 283-295.

Teaf, C.M., Cover, D.J., Teaf, P.A., Page, E., and Starks, M.J., 2010, Proceedings of the Annual International Conference on Soils, Sediments, Water and Energy: Arsenic Cleanup Criteria for Soils in the US and Abroad: Comparing Guidelines and Understanding Inconsistencies, v. 15; no. 10, 10 p.

Thayer, T.P., 1933, Structural relations of central Willamette Valley to Cascade Mountains [abs.]: Pan-American Geologist, v. 59, no. 4, p. 317.

Thayer, T.P., 1936, Structure of the North Santiam River section of the Cascade Mountains in Oregon: Journal of Geology, v. 44, no. 6, p. 701-716.

Thayer, T.P., 1939, Geology of the Salem Hills and the North Santiam River Basin, Oregon: Oregon Department of Geology and Mineral Industries, Bulletin 15, $40 \mathrm{p}$. 
Trimble, D.E., 1963, Geology of Portland, Oregon, and Adjacent Areas, U.S. Geological Survey Bulletin 1119, 119 p.

Verplanck, E.P., 1985, Temporal variations in volume and geochemistry of volcanism in the western Cascades, Oregon: Corvallis, Oregon, Oregon State University, M.S. Thesis, $115 \mathrm{p}$.

Walker, G.W., 1979, Revisions to the Cenozoic Stratigraphy of Harney Basin, Southeastern Oregon: U.S. Geological Survey, Bulletin 1475, 35 p.

Walker, G.W. and MacLeod, N.S., 1991, Geologic Map of Oregon: U.S. Geological Survey, scale 1:500,000. <http://tin.er.usgs.gov/geology/state/state.php?state=OR>

Warren, W.C., Norbisrath, H., and Grivetti, R.M., 1945, Geology of Northwestern Oregon: U.S. Geological Survey, Oil and Gas Investigations Preliminary Map 42, scale 1:190,000.

Waters, A.C., 1973, The Columbia River Gorge: Basalt stratigraphy, ancient lava dams, and landslide dams, in Geologic Field Trips in Northern Oregon and Southern Washington: Oregon Department of Geology and Mineral Industries, Bulletin 77, p. 135-154.

Wells, R.E., Niem, A.R., MacLeod, N.S., Snavely, P.D., Jr., and Niem, W.A., 1983, Preliminary Geologic Map of the West Half of the Vancouver (WashingtonOregon) $1^{\circ}$ by $2^{\circ}$ Quadrangle, Oregon: U.S. Geological Survey, Open-File Report 85-591, scale 1:250,000.

White, C.M., 1980a, Geology of the Breitenbush Hot Springs Quadrangle, Oregon: Oregon Department of Geology and Mineral Industries Special Paper 9, 26 p.

White, C.M., 1980b, Geology and geochemistry of volcanic rocks in the Detroit area, western Cascade Range, Oregon: Eugene, Oregon, University of Oregon, Ph.D. dissertation, $178 \mathrm{p}$.

Wise, W.S., 1969, Geology and petrology of the Mount Hood area-a study of High Cascade volcanism: Geological Society of America Bulletin , v. 80, p. 969-1006.

Wolfe, J.A., 1981, A Chronologic framework for Cenozoic megafossil floras of northwestern North America and its relation to marine geochronology, in Armentrout, J.M., ed., Pacific Northwest Cenozoic Biostratigraphy: Geological Society of America Special Paper 184, p. 39-47. 
Yan-Chu, H., 1994, Arsenic distribution in soils, in Nriagu, J.O. ed., Arsenic in the Environment Part I: Cycling and Characterization, John Wiley and Sons, Inc., New York, NY, p. 17-49. 
Appendix A: Overview U.S. and International Arsenic Cleanup Levels

\begin{tabular}{|c|c|c|c|c|}
\hline LOCATION & AGENCY & $\begin{array}{l}\text { EXPOSURE } \\
\text { PATHWAY }\end{array}$ & $\begin{array}{l}\text { RELEVANT } \\
\text { ARSENIC } \\
\text { LEVEL }\end{array}$ & SOURCE \\
\hline $\begin{array}{l}\text { New Jersey, } \\
\text { United } \\
\text { States }\end{array}$ & $\begin{array}{l}\text { New Jersey } \\
\text { Department of } \\
\text { Environmental } \\
\text { Protection } \\
\text { (NJDEP) }\end{array}$ & $\begin{array}{l}\text { Residental } \\
\text { and non- } \\
\text { residental } \\
\text { soils }\end{array}$ & $20 \mathrm{mg} / \mathrm{kg}$ & Chen et al., 2001 \\
\hline \multirow{2}{*}{$\begin{array}{l}\text { Florida, } \\
\text { United } \\
\text { States }\end{array}$} & \multirow{2}{*}{$\begin{array}{c}\text { Florida } \\
\text { Department of } \\
\text { Environmental } \\
\text { Protection } \\
\text { (FDEP }\end{array}$} & $\begin{array}{l}\text { Residential } \\
\text { Soils }\end{array}$ & $.80 \mathrm{mg} / \mathrm{kg}$ & \multirow[b]{2}{*}{ Chen et al., 2001} \\
\hline & & $\begin{array}{l}\text { Non- } \\
\text { residential } \\
\text { Soils }\end{array}$ & $3.7 \mathrm{mg} / \mathrm{kg}$ & \\
\hline \multirow{2}{*}{$\begin{array}{l}\text { Montana, } \\
\text { United } \\
\text { States }\end{array}$} & \multirow{2}{*}{$\begin{array}{l}\text { Montana } \\
\text { Department of } \\
\text { Environmental } \\
\text { Quality }\end{array}$} & $\begin{array}{l}\text { Surface Soil } \\
\left(<2^{\prime} \text { deep) }\right.\end{array}$ & $40 \mathrm{mg} / \mathrm{kg}$ & $\begin{array}{l}\text { Montana DEQ Arsenic Policy } \\
\text { (http://deq.mt.gov/StateSuperfund/ } \\
\text { PDFs/ArsenicPositionPaper.pdf) }\end{array}$ \\
\hline & & $\begin{array}{l}\text { Subsurface } \\
\text { Soil (>2' } \\
\text { deep) }\end{array}$ & 300 mg/kg & $\frac{\text { http://deq.mt.gov/StateSuperfund/f }}{\underline{\text { requentlyaskedquestions.mcpx }}}$ \\
\hline $\begin{array}{l}\text { Washington, } \\
\text { United } \\
\text { States }\end{array}$ & $\begin{array}{c}\text { State of } \\
\text { Washington } \\
\text { Department of } \\
\text { Ecology } \\
\text { (for Tacoma } \\
\text { Smelter Plume) }\end{array}$ & & $20 \mathrm{ppm}$ & $\frac{\text { https://fortress.wa.gov/ecy/publicati }}{\text { ons/publications/1109095.pdf }}$ \\
\hline Wisconsin & $\begin{array}{c}\text { Wisconsin } \\
\text { Department of } \\
\text { Natural } \\
\text { Resources, } \\
2009 \\
\end{array}$ & $\begin{array}{l}\text { Residential } \\
\text { /Unrestrict } \\
\text { ed Use }\end{array}$ & 0.039 & Teaf et al., 2010 \\
\hline California & $\begin{array}{l}\text { California } \\
\text { Environmental } \\
\text { Protection } \\
\text { Agency, } 2005 \\
\end{array}$ & $\begin{array}{l}\text { Residential } \\
\text { /Unrestrict } \\
\text { ed Use }\end{array}$ & 0.07 & Teaf et al., 2010 \\
\hline Maine & $\begin{array}{c}\text { Main } \\
\text { Department of } \\
\text { Environmental } \\
\text { Protection, } \\
2009 \\
\end{array}$ & $\begin{array}{l}\text { Residential } \\
\text { /Unrestrict } \\
\text { ed Use }\end{array}$ & 1.4 & Teaf et al., 2010 \\
\hline Ohio & $\begin{array}{l}\text { Ohio } \\
\text { Environmental } \\
\text { Protection } \\
\text { Agency, 2008 }\end{array}$ & $\begin{array}{l}\text { Residential } \\
\quad / \\
\text { Unrestricte } \\
\text { d Use }\end{array}$ & 6.7 & Teaf et al., 2010 \\
\hline
\end{tabular}




\section{Appendix A: Overview of Mandatory Cleanup Levels (Continued)}

\begin{tabular}{|c|c|c|c|c|}
\hline LOCATION & AGENCY & $\begin{array}{l}\text { EXPOSURE } \\
\text { PATHWAY }\end{array}$ & $\begin{array}{l}\text { RELEVANT } \\
\text { ARSENIC } \\
\text { LEVEL }\end{array}$ & SOURCE \\
\hline $\begin{array}{c}\text { Alabama, } \\
\text { Colorado, } \\
\text { Delaware, } \\
\text { Idaho, } \\
\text { Louisiana, } \\
\text { Maryland, } \\
\text { Missouri, } \\
\text { North } \\
\text { Carolina, } \\
\text { Oklahoma, } \\
\text { Oregon, } \\
\text { Virginia, } \\
\text { West } \\
\text { Virginia, } \\
\text { Wyoming }\end{array}$ & $\begin{array}{l}\text { Alabama Department of } \\
\text { Environmental Management, 2008; } \\
\text { Colorado Department of Public } \\
\text { Health, 2007; Delaware } \\
\text { Department of Natural Resources } \\
\text { and Environmental Control, 2007; } \\
\text { Idaho Department of } \\
\text { Environmental Quality, 2004; } \\
\text { Louisiana Department of } \\
\text { Environmental Quality, 2003; } \\
\text { Maryland Department of the } \\
\text { Environmenta, 2008; Missouri Risk } \\
\text { Based Corrective Action, 2006; } \\
\text { North Carolina Department of } \\
\text { Environment and Natural } \\
\text { Resources, 2005; Oklahoma } \\
\text { Department of Environmental } \\
\text { Quality, 2007; Oregon Department } \\
\text { of Environmental Quality, 2005; } \\
\text { Virginia Department of } \\
\text { Environmental Quality, 2009; West } \\
\text { Virginia Department of } \\
\text { Environmental Protection, 2009; } \\
\text { Wyoming Department of } \\
\text { Environmental Quality, 2009 }\end{array}$ & $\begin{array}{c}\text { Residential/ } \\
\text { Unrestricted } \\
\text { Use }\end{array}$ & .38 to .41 & $\begin{array}{l}\text { Teaf et al., } \\
2010\end{array}$ \\
\hline Florida & $\begin{array}{c}\text { Florida Department of } \\
\text { Environmental Protection, } 2005\end{array}$ & $\begin{array}{l}\text { Residential/Un } \\
\text { restricted Use }\end{array}$ & 2.1 & $\begin{array}{l}\text { Teaf et al., } \\
2010\end{array}$ \\
\hline New Mexico & $\begin{array}{l}\text { New Mexico Environment } \\
\text { Department, } 2009\end{array}$ & $\begin{array}{l}\text { Residential/Un } \\
\text { restricted Use }\end{array}$ & 3.59 & $\begin{array}{l}\text { Teaf et al., } \\
2010\end{array}$ \\
\hline Indiana & $\begin{array}{c}\text { Indiana Department of } \\
\text { Environmental Management, } 2009\end{array}$ & $\begin{array}{c}\text { Residential/ } \\
\text { Unrestricted } \\
\text { Use }\end{array}$ & 3.9 & $\begin{array}{l}\text { Teaf et al., } \\
2010\end{array}$ \\
\hline
\end{tabular}




\section{Appendix A : Overview of Mandatory Cleanup Levels (Continued)}

\begin{tabular}{|c|c|c|c|c|}
\hline LOCATION & AGENCY & $\begin{array}{l}\text { EXPOSURE } \\
\text { PATHWAY }\end{array}$ & $\begin{array}{c}\text { RELEVANT } \\
\text { ARSENIC } \\
\text { LEVEL }\end{array}$ & SOURCE \\
\hline Texas & $\begin{array}{c}\text { Texas Commission on } \\
\text { Environmental Quality, } 2009\end{array}$ & $\begin{array}{c}\text { Residential/ } \\
\text { Unrestricted Use }\end{array}$ & 24 & $\begin{array}{c}\text { Teaf et al., } \\
2010\end{array}$ \\
\hline $\begin{array}{l}\text { Arizona, lowa, } \\
\text { Kansas, } \\
\text { Kentucky, } \\
\text { Massachusetts } \\
\text {, Minnesotta, } \\
\text { Missouri, New } \\
\text { Hampshire, } \\
\text { New Jersey, } \\
\text { New York, } \\
\text { Pennsylvania, } \\
\text { Rhode Island, } \\
\text { Washington }\end{array}$ & $\begin{array}{l}\text { Arizona Department of } \\
\text { Environmental Quality, 2002; } \\
\text { lowa Department of Natural } \\
\text { Resources, 2004; Kansas } \\
\text { Department of Health and } \\
\text { Environment, 2007; Code of } \\
\text { Massachusetts Regulation } \\
\text { Department of } \\
\text { Environmental Protection, } \\
\text { 2003; Montana Department } \\
\text { of Environmental Quality, } \\
\text { 2005; Missouri Risk Based } \\
\text { Corrective Action, 2006; New } \\
\text { Hampshire Department of } \\
\text { Environmental Services, } \\
\text { 2007; New Jersey } \\
\text { Administrative Code, 2008; } \\
\text { New York State Department } \\
\text { of Environmental } \\
\text { Conservation and New York } \\
\text { State Department of Health, } \\
\text { 2006; Pennsylvania } \\
\text { Department of } \\
\text { Environmental Protection, } \\
\text { 2001; Rhode Island } \\
\text { Department of } \\
\text { Environmental Management, } \\
\text { 1996; Washington } \\
\text { Administrative Code, 2007 }\end{array}$ & $\begin{array}{c}\text { Residential/ } \\
\text { Unrestricted Use }\end{array}$ & 7 to 40 & $\begin{array}{l}\text { Teaf et al., } \\
2010\end{array}$ \\
\hline
\end{tabular}




\section{Appendix A: Overview of Mandatory Cleanup Levels (Continued)}

\begin{tabular}{|c|c|c|c|c|}
\hline LOCATION & AGENCY & EXPOSURE PATHWAY & $\begin{array}{l}\text { RELEVANT } \\
\text { ARSENIC } \\
\text { LEVEL }\end{array}$ & SOURCE \\
\hline Finland & $\begin{array}{c}\text { Finland Ministry of the } \\
\text { Environment, } 2007\end{array}$ & $\begin{array}{c}\text { Residential/Unrestricted } \\
\text { Use }\end{array}$ & 5 & $\begin{array}{c}\text { Teaf et al., } \\
2010\end{array}$ \\
\hline Canada & $\begin{array}{l}\text { Canadian Council of } \\
\text { Ministers of the } \\
\text { Environment, } 2007\end{array}$ & $\begin{array}{c}\text { Residential/Unrestricted } \\
\text { Use }\end{array}$ & 12 & $\begin{array}{c}\text { Teaf et al., } \\
2010\end{array}$ \\
\hline UK & $\begin{array}{c}\text { United Kingdom } \\
\text { Environment Agency, } \\
2009 \\
\end{array}$ & $\begin{array}{c}\text { Residential/Unrestricted } \\
\text { Use }\end{array}$ & 32 & $\begin{array}{c}\text { Teaf et al., } \\
2010\end{array}$ \\
\hline Netherlands & $\begin{array}{c}\text { Netherlands } \\
\text { Environmental } \\
\text { Assessment Agency, } 2008\end{array}$ & $\begin{array}{c}\text { Residential/Unrestricted } \\
\text { Use }\end{array}$ & 76 & $\begin{array}{c}\text { Teaf et al., } \\
2010\end{array}$ \\
\hline Australia & $\begin{array}{c}\text { Australia National } \\
\text { Environment Protection } \\
\text { Council, } 1999 \\
\end{array}$ & $\begin{array}{c}\text { Residential/Unrestricted } \\
\text { Use }\end{array}$ & 100 & $\begin{array}{c}\text { Teaf et al., } \\
2010\end{array}$ \\
\hline Japan & $\begin{array}{l}\text { Japan Ministry of the } \\
\text { Environment, } 2003\end{array}$ & $\begin{array}{c}\text { Residential/Unrestricted } \\
\text { Use }\end{array}$ & 150 & $\begin{array}{c}\text { Teaf et al., } \\
2010\end{array}$ \\
\hline \multirow{3}{*}{ Canada } & \multirow{3}{*}{$\begin{array}{l}\text { Ministry of Environment } \\
\text { of Canada }\end{array}$} & Agricultural & $25 \mathrm{mg} / \mathrm{kg}$ & \multirow{3}{*}{$\begin{array}{c}\text { Chen et al., } \\
2001\end{array}$} \\
\hline & & Industrial & $50 \mathrm{mg} / \mathrm{kg}$ & \\
\hline & & Residential & $25 \mathrm{mg} / \mathrm{kg}$ & \\
\hline \multirow{2}{*}{$\begin{array}{l}\text { United } \\
\text { Kingdom }\end{array}$} & & Domestic Gardens & $10 \mathrm{mg} / \mathrm{kg}$ & \multirow{2}{*}{$\begin{array}{c}\text { Chen et al., } \\
2001\end{array}$} \\
\hline & & $\begin{array}{l}\text { Parks, Playing Fields, } \\
\text { Open Spaces }\end{array}$ & $40 \mathrm{mg} / \mathrm{kg}$ & \\
\hline
\end{tabular}


Appendix B: Overview of Arsenic Content by Rock Type

Appendix B: Dataset 1; From Tanaka (1988)

IGNEOUS ROCKS:

\begin{tabular}{|c|c|c|c|c|c|c|c|c|c|}
\hline \multirow[b]{2}{*}{$\begin{array}{l}\text { Lithologic } \\
\text { Group }\end{array}$} & \multirow[b]{2}{*}{$\begin{array}{c}\text { Examples } \\
\text { of rock- } \\
\text { types }\end{array}$} & \multicolumn{4}{|c|}{ Onishi and Sandell (1955) } & \multicolumn{4}{|c|}{ Boyle and Jonasson (1973) } \\
\hline & & $\begin{array}{c}\text { Number } \\
\text { Samples } \\
\text { Tested }\end{array}$ & $\begin{array}{l}\text { Low } \\
\text { (mg/ } \\
\text { kg) }\end{array}$ & $\begin{array}{l}\text { High } \\
\text { (mg/ } \\
\text { kg) }\end{array}$ & $\begin{array}{l}\text { Average } \\
\text { (mg/kg) }\end{array}$ & $\begin{array}{c}\text { Number } \\
\text { Samples } \\
\text { Tested }\end{array}$ & $\begin{array}{l}\text { Low } \\
\text { (mg/ } \\
\mathrm{kg} \text { ) }\end{array}$ & $\begin{array}{l}\text { High } \\
\text { (mg/ } \\
\mathrm{kg} \text { ) }\end{array}$ & $\begin{array}{l}\text { Average } \\
\text { (mg/kg) }\end{array}$ \\
\hline \multirow{2}{*}{$\begin{array}{l}\text { Ultrabasic } \\
\text { Group }\end{array}$} & $\begin{array}{c}\text { Dunite, } \\
\text { Pyrox- } \\
\text { enite }\end{array}$ & 19 & 0.3 & 3 & 1 & 40 & $\begin{array}{c}0.03 \\
4\end{array}$ & 15.8 & 1.5 \\
\hline & $\begin{array}{c}\text { Serpen- } \\
\text { tinite }\end{array}$ & 8 & 0.8 & 6.6 & 2.8 & - & - & - & - \\
\hline $\begin{array}{c}\text { Mafic - } \\
\text { Extrusives }\end{array}$ & Basalt & 113 & 0.1 & 9 & 1.4 & 78 & 0.18 & 113 & 2.3 \\
\hline $\begin{array}{c}\text { Mafic - } \\
\text { Intrusives }\end{array}$ & $\begin{array}{l}\text { Gabbro, } \\
\text { Diabase }\end{array}$ & 32 & $\begin{array}{c}0.06 \\
6 \\
\end{array}$ & 5.6 & 1.4 & 112 & $\begin{array}{c}0.06 \\
1 \\
\end{array}$ & 28 & 1.5 \\
\hline $\begin{array}{c}\text { Inter- } \\
\text { mediate - } \\
\text { Extrusives }\end{array}$ & $\begin{array}{c}\text { Andesite, } \\
\text { Dacite }\end{array}$ & 33 & 0.5 & 5.8 & 2.2 & 30 & 0.5 & 5.8 & 2.7 \\
\hline $\begin{array}{l}\text { Inter- } \\
\text { mediate - } \\
\text { Instrusives }\end{array}$ & $\begin{array}{l}\text { Diorite, } \\
\text { Grano- } \\
\text { diorite, } \\
\text { Syenite }\end{array}$ & 6 & 0.59 & 2.3 & 1.4 & 39 & $\begin{array}{c}0.09 \\
1\end{array}$ & 13.4 & 1.03 \\
\hline $\begin{array}{c}\text { Felsic - } \\
\text { Extrusives }\end{array}$ & Rhyolite & 52 & 0.2 & 12.2 & 3.1 & 2 & 3.2 & 5.4 & 4.3 \\
\hline $\begin{array}{c}\text { Felsic - } \\
\text { Intrusives }\end{array}$ & Granite & 148 & 0 & 8.5 & 1.9 & 116 & 0.18 & 15 & 1.29 \\
\hline
\end{tabular}




\section{Appendix B: Dataset 1; From Tanaka (1988) (Continued)}

\section{SEDIMENTARY ROCKS:}

\begin{tabular}{|c|c|c|c|c|c|c|c|c|c|}
\hline \multirow[b]{2}{*}{$\begin{array}{l}\text { Lithologic } \\
\text { Group }\end{array}$} & \multirow[b]{2}{*}{$\begin{array}{c}\text { Examples } \\
\text { of rock- } \\
\text { types }\end{array}$} & \multicolumn{4}{|c|}{ Onishi and Sandell (1955) } & \multicolumn{4}{|c|}{ Boyle and Jonasson (1973) } \\
\hline & & $\begin{array}{c}\text { Number } \\
\text { Samples } \\
\text { Tested }\end{array}$ & $\begin{array}{c}\text { Low } \\
\text { (mg/ } \\
\mathrm{kg})\end{array}$ & $\begin{array}{c}\text { High } \\
\text { (mg/ } \\
\mathrm{kg})\end{array}$ & $\begin{array}{l}\text { Average } \\
\text { (mg/kg) }\end{array}$ & $\begin{array}{c}\text { Number } \\
\text { Samples } \\
\text { Tested }\end{array}$ & $\begin{array}{c}\text { Low } \\
\text { (mg/ } \\
\mathrm{kg})\end{array}$ & $\begin{array}{c}\text { High } \\
\text { (mg/ } \\
\mathrm{kg})\end{array}$ & $\begin{array}{l}\text { Average } \\
\text { (mg/kg) }\end{array}$ \\
\hline \multirow{2}{*}{$\begin{array}{c}\text { Recent } \\
\text { Sediments }\end{array}$} & $\begin{array}{l}\text { Stream, } \\
\text { River, } \\
\text { Lake } \\
\text { Sediments }\end{array}$ & - & - & - & - & 9691 & 1 & $\begin{array}{c}1300 \\
0\end{array}$ & 14.1 \\
\hline & $\begin{array}{c}\text { Ocean } \\
\text { Sediments }\end{array}$ & 30 & 0.4 & 60 & 13.7 & 75 & 0.4 & 455 & 33.7 \\
\hline \multirow{4}{*}{$\begin{array}{c}\text { Clastic } \\
\text { Sedimen- } \\
\text { tary Rocks }\end{array}$} & $\begin{array}{c}\text { Shales, } \\
\text { Black } \\
\text { Shales, } \\
\text { Pyritic } \\
\text { Shales }\end{array}$ & - & - & - & - & 75 & 3 & 500 & 17 \\
\hline & $\begin{array}{c}\text { Shale, } \\
\text { Argillite, } \\
\text { Slate }\end{array}$ & 304 & 0.3 & 59 & 12.3 & 113 & 0.3 & 500 & 14.5 \\
\hline & \multirow{2}{*}{$\begin{array}{l}\text { Sand- } \\
\text { stone, } \\
\text { Arkose, } \\
\text { Conglom- } \\
\text { erate }\end{array}$} & $10^{1}$ & $0.6^{1}$ & $9.7^{1}$ & $2.3^{1}$ & 15 & 0.6 & 120 & 4.1 \\
\hline & & 98 & - & - & 15.5 & & - & - & - \\
\hline \multirow[b]{2}{*}{$\begin{array}{l}\text { Chemical } \\
\text { Sedimen- } \\
\text { tary Rocks }\end{array}$} & $\begin{array}{c}\text { Lime- } \\
\text { stone, } \\
\text { Dolomite }\end{array}$ & 37 & 0.1 & 23.5 & 3.5 & 40 & 0.1 & 20.1 & 2.6 \\
\hline & $\begin{array}{c}\text { Iron } \\
\text { Forma- } \\
\text { tions, } \\
\text { Iron-rich } \\
\text { Sediments }\end{array}$ & - & - & - & - & 45 & 1 & 2900 & - \\
\hline \multirow[t]{2}{*}{ Evaporites } & $\begin{array}{c}\text { Gypsum, } \\
\text { Anhy- } \\
\text { drite, etc. }\end{array}$ & - & - & - & - & 5 & 0.1 & 10 & 3.5 \\
\hline & $\begin{array}{l}\text { Phos- } \\
\text { phorite }\end{array}$ & 95 & 0.4 & 188 & 17.4 & 41 & 3.4 & 100 & 14.6 \\
\hline
\end{tabular}

1. Excludes 88 samples from the Chinle Formation. Additional average value includes these samples. 
Appendix B: Dataset 1; From Tanaka (1988) (Continued)

METAMORPHIC ROCKS:

\begin{tabular}{|c|c|c|c|c|c|c|c|c|c|}
\hline \multirow[b]{2}{*}{$\begin{array}{l}\text { Lithologic } \\
\text { Group }\end{array}$} & \multirow[b]{2}{*}{$\begin{array}{c}\text { Examples } \\
\text { of rock- } \\
\text { types }\end{array}$} & \multicolumn{4}{|c|}{ Onishi and Sandell (1955) } & \multicolumn{4}{|c|}{ Boyle and Jonasson (1973) } \\
\hline & & $\begin{array}{c}\text { Number } \\
\text { Samples } \\
\text { Tested }\end{array}$ & $\begin{array}{l}\text { Low } \\
\text { (mg/ } \\
\mathrm{kg})\end{array}$ & $\begin{array}{l}\text { High } \\
\text { (mg/ } \\
\text { kg) }\end{array}$ & $\begin{array}{l}\text { Average } \\
\text { (mg/kg) }\end{array}$ & $\begin{array}{c}\text { Number } \\
\text { Samples } \\
\text { Tested }\end{array}$ & $\begin{array}{l}\text { Low } \\
\text { (mg/ } \\
\mathrm{kg})\end{array}$ & $\begin{array}{l}\text { High } \\
\text { (mg/ } \\
\text { kg) }\end{array}$ & $\begin{array}{l}\text { Average } \\
\text { (mg/kg) }\end{array}$ \\
\hline \multirow{2}{*}{$\begin{array}{l}\text { Sedimen- } \\
\text { tary Origin }\end{array}$} & Quartzite & 40 & 2.2 & 70 & 6.4 & 4 & 2.2 & 7.6 & 5.5 \\
\hline & $\begin{array}{c}\text { Slate, } \\
\text { Phyllite }\end{array}$ & 32 & 0.5 & 70 & 16.5 & 75 & 0.5 & 143 & 18.1 \\
\hline \multirow{2}{*}{$\begin{array}{c}\text { Contact } \\
\text { Metamor- } \\
\text { phism }\end{array}$} & Hornfels & 1 & 0.7 & 0.7 & 0.7 & 2 & 0.7 & 11 & 5.9 \\
\hline & Skarn & 6 & 5 & 20 & 11 & - & - & - & - \\
\hline \multirow{3}{*}{$\begin{array}{l}\text { Regional } \\
\text { Metamor- } \\
\text { phism }\end{array}$} & Schist & 13 & 0.4 & 15 & 3.9 & 9 & 0 & 18.5 & 1.1 \\
\hline & Gneiss & 4 & 0.5 & 2.2 & 1.3 & 7 & 0.5 & 4.1 & 1.5 \\
\hline & $\begin{array}{l}\text { Amphi- } \\
\text { bolite, } \\
\text { Green- } \\
\text { stone }\end{array}$ & 1 & 2.2 & 2.2 & 2.2 & 45 & 0.4 & 45 & 6.3 \\
\hline
\end{tabular}


Appendix B: Dataset 2; From Mandal and Suzuki (2001)

Material

Igneous (6)

Acidic

Rhyolite (extrusive)

Granite (intrusive)

Intermediate

Latite, andesite, trachyte (extrusive)

Diorite, granodiorite, syenite (intrusive)

Basic

Basalt (extrusive)

Gabbro (intrusive)

Ultrabasic

Peridotite, dunite, serpentinite

Metamorphic (7-9)

Quartzite

Slate/phyllite

Schist/gneiss

Sedimentary (7-9)

Marine

Shale/claystone (nearshore)

Shale/claystone (offshore)

Carbonates

Phosphorites

Sandstone

Non-marine

Shales

Claystone

Recent Sediments (marine)

Muds (9)

Clays (9)

Carbonate (10)

Stream/river (11)

Lake (12)

Soils (13)
Arsenic Content (in $\mathrm{mg} / \mathrm{kg}^{-1}$ )

\author{
3.2-5.4 \\ 0.18-15
}

$0.5-5.8$

$0.09-13.4$

0.18-113

0.06-28

$0.3-15 . .8$

2.2-7.6

$0.5-143$

$0.0-18.5$

4.0-25

3.0-490

0.1-20.1

$0.4-188$

$0.6-9$

3.0-12

3.0-10

3.2-60

4.0-20

$<1.0$

5.0-4000 (mineralized area)

2.0-300

$<0.1-97$ 
Appendix C: Site Observations for Phase I (1995) Sites (Ashbaugh, 1995)

(Descriptions of soils taken at these sites are described in Appendix D: Description of Phase I Soil Samples (Ashbaugh, 1995))

\begin{tabular}{|c|c|c|c|c|c|c|}
\hline Site & $\begin{array}{c}\text { Easting } \\
\text { (UTM } \\
\text { NAD 83) }\end{array}$ & $\begin{array}{l}\text { Northing } \\
\text { (UTM } \\
\text { NAD 83) }\end{array}$ & $\begin{array}{l}\text { Elevation } \\
\text { (m) }\end{array}$ & Vegetation & Drainage & $\begin{array}{c}\text { Underlying } \\
\text { Geologic } \\
\text { Unit }\end{array}$ \\
\hline $\mathrm{C} 1$ & 52209 & 5039042 & 191 & Douglas Fir & $\begin{array}{l}\text { Moderately - } \\
\text { well drained }\end{array}$ & Qs \\
\hline $\mathrm{C} 2$ & 503643 & 5046637 & 55 & Douglas fir & Well drained & Qs \\
\hline $\mathrm{C} 3$ & 487002 & 5056635 & 122 & Douglas fir & Well drained & Tc \\
\hline $\mathrm{C} 4$ & 483559 & 5059728 & 146 & Douglas fir & Well drained & Tmst \\
\hline $\mathrm{C} 5$ & 475233 & 5076304 & 441 & Douglas fir & Well drained & Tco \\
\hline $\mathrm{C} 6$ & 478660 & 5065818 & 340 & Douglas fir & Well drained & Tco \\
\hline $\mathrm{C7}$ & 473195 & 5069554 & 267 & Douglas fir & Well drained & Tco \\
\hline $\mathrm{C} 8$ & 453382 & 5073882 & 116 & Spruce & Well drained & Ttv \\
\hline C9 & 447913 & 5082998 & 122 & Douglas fir & Well drained & Tss \\
\hline $\mathrm{C} 10$ & 447059 & 5083464 & 407 & Huckleberry & Well drained & $\mathrm{Ti}$ \\
\hline C11 & 429230 & 5090474 & 15 & $\begin{array}{l}\text { Douglas fir, } \\
\text { Spruce }\end{array}$ & Well drained & Tms \\
\hline C12 & 462768 & 5062718 & 733 & Douglas fir & Well drained & Ttv \\
\hline C13 & 466104 & 4937226 & 146 & Douglas fir & Well drained & Tsr \\
\hline C14 & 449814 & 49806902 & 182 & Douglas fir & Well drained & $\mathrm{Tt}$ \\
\hline C15 & 449880 & 4906339 & 255 & Douglas fir & Well drained & $\mathrm{Tt}$ \\
\hline M1 & 578682 & 5022223 & 366 & $\begin{array}{l}\text { Douglas fir, } \\
\text { Cedar }\end{array}$ & Well drained & Qal \\
\hline M2 & 581417 & 5018888 & 474 & $\begin{array}{l}\text { Douglas fir, } \\
\text { Maple }\end{array}$ & Well drained & QTba \\
\hline M3 & 585815 & 5019067 & 518 & $\begin{array}{c}\text { Douglas fir, } \\
\text { Cedar }\end{array}$ & Well drained & Qal \\
\hline M4 & 595656 & 5017183 & 1106 & Douglas fir & Well drained & Qg \\
\hline M5 & 601650 & 5017695 & 1459 & $\begin{array}{c}\text { Huckleberry, } \\
\text { True fir }\end{array}$ & Well drained & Qa \\
\hline M6 & 603308 & 5015023 & 1252 & Douglas fir & Well drained & $\mathrm{Qa}$ \\
\hline M7 & 602981 & 5005326 & 1191 & Douglas fir & Well drained & QTba \\
\hline M8 & 637441 & 4933297 & 620 & $\begin{array}{l}\text { Juniper, } \\
\text { Sagebrush }\end{array}$ & Well drained & Ts \\
\hline M9 & 639027 & 4933925 & 790 & Sagebrush & Well drained & Ts \\
\hline M10 & 647676 & 4940502 & 729 & Grass & Well drained & Ts \\
\hline
\end{tabular}


Appendix C: Site Observations for Phase I(1995) Sites (Ashbaugh, 1995) (Continued) (Descriptions of soils taken at these sites are described in Appendix D: Description of Phase I Soil Samples (Ashbaugh, 1995))

\begin{tabular}{|c|c|c|c|c|c|c|}
\hline Site & $\begin{array}{c}\text { Easting } \\
\text { (UTM } \\
\text { NAD 83) }\end{array}$ & $\begin{array}{c}\text { Northing } \\
\text { (UTM } \\
\text { NAD 83) }\end{array}$ & $\begin{array}{l}\text { Elevation } \\
\text { (m) }\end{array}$ & Vegetation & Drainage & $\begin{array}{c}\text { Underlying } \\
\text { Geologic } \\
\text { Unit }\end{array}$ \\
\hline M11 & 639253 & 4960466 & 486 & $\begin{array}{l}\text { Ponderosa } \\
\text { pine, Juniper } \\
\text { Sagebrush }\end{array}$ & Well drained & Tsfj \\
\hline M12 & 631098 & 4962527 & 790 & $\begin{array}{l}\text { Ponderosa } \\
\text { pine, Juniper, } \\
\text { Sagebrush }\end{array}$ & Well drained & Tob \\
\hline M13 & 623961 & 4971108 & 802 & $\begin{array}{l}\text { Sagebrush, } \\
\text { Grass }\end{array}$ & Well drained & Qgs \\
\hline M14 & 627175 & 4980627 & 742 & $\begin{array}{c}\text { Ponderosa } \\
\text { pine, Juniper, } \\
\text { Grass }\end{array}$ & $\begin{array}{l}\text { Moderately - } \\
\text { well drained }\end{array}$ & Tca \\
\hline M15 & 630735 & 4982276 & 790 & $\begin{array}{c}\text { Ponderosa } \\
\text { pine, Juniper, } \\
\text { Sagebrush, } \\
\text { Grass }\end{array}$ & Well drained & Tsfj \\
\hline M16 & 634767 & 4991684 & 681 & $\begin{array}{c}\text { Juniper, } \\
\text { Sagebrush, } \\
\text { Grass }\end{array}$ & Well drained & Tcg \\
\hline M17 & 620659 & 4995427 & 960 & $\begin{array}{c}\text { Ponderosa } \\
\text { pine, Douglas } \\
\text { fir }\end{array}$ & Well drained & Qtba \\
\hline M18 & 564920 & 4952727 & 486 & $\begin{array}{l}\text { Douglas fir, } \\
\text { Vine maple }\end{array}$ & Well drained & Tu \\
\hline M20 & 583707 & 4944123 & 729 & $\begin{array}{c}\text { Douglas fir, } \\
\text { Huckleberry, } \\
\text { Cedar }\end{array}$ & Well drained & QTba \\
\hline $\mathrm{M} 21$ & 580192 & 4925274 & 1143 & Douglas fir & Well drained & QTba \\
\hline $\mathrm{M} 22$ & 583605 & 4920961 & 1119 & Douglas fir & Well drained & Qyb \\
\hline M23 & 590619 & 4918395 & 1489 & $\begin{array}{c}\text { Spruce, } \\
\text { Douglas fir, } \\
\text { Lodgepole } \\
\text { pine }\end{array}$ & Well drained & QTba \\
\hline M24 & 572420 & 4916602 & 1079 & $\begin{array}{l}\text { Ponderosa } \\
\text { pine }\end{array}$ & Well drained & QTba \\
\hline
\end{tabular}


Appendix C: Site Observations for Phase I(1995) Sites (Ashbaugh, 1995) (Continued) (Descriptions of soils taken at these sites are described in Appendix D: Description of Phase I Soil Samples (Ashbaugh, 1995))

\begin{tabular}{|c|c|c|c|c|c|c|}
\hline Site & $\begin{array}{c}\text { Easting } \\
\text { (UTM } \\
\text { NAD 83) }\end{array}$ & $\begin{array}{l}\text { Northing } \\
\text { (UTM } \\
\text { NAD 83) }\end{array}$ & $\begin{array}{c}\text { Elevation } \\
\text { (m) }\end{array}$ & Vegetation & Drainage & $\begin{array}{c}\text { Underlying } \\
\text { Geologic } \\
\text { Unit }\end{array}$ \\
\hline P1 & 528311 & 5044245 & 79 & Douglas fir & Well drained & Qgs \\
\hline $\mathrm{P} 2$ & 554815 & 5018163 & 79 & Douglas fir & Well drained & Qgs \\
\hline P3 & 527879 & 5045407 & 58 & Douglas fir & Well drained & Qgs \\
\hline P4 & 528949 & 5042701 & 46 & Douglas fir & Well drained & Qs \\
\hline P5 & 526892 & 5043608 & 58 & Douglas fir & Well drained & Qs \\
\hline P6 & 513128 & 5049466 & 280 & Douglas fir & Well drained & Qs \\
\hline P7 & 520862 & 5042653 & 261 & Douglas fir & Well drained & Qs \\
\hline P8 & 554815 & 5018163 & 267 & Grass & Well drained & QTba \\
\hline P9 & 553925 & 5018732 & 261 & Douglas fir & $\begin{array}{l}\text { Moderately- } \\
\text { well drained }\end{array}$ & QTba \\
\hline P10 & 551620 & 5019797 & 207 & $\begin{array}{c}\text { Alder, } \\
\text { Cottonwood }\end{array}$ & Well drained & QTba \\
\hline P11 & 5488523 & 5018316 & 76 & $\begin{array}{l}\text { Douglas fir, } \\
\text { Vine maple, } \\
\text { Oregon grape }\end{array}$ & Well drained & Qal \\
\hline P12 & 549544 & 5019348 & 117 & $\begin{array}{l}\text { Douglas fir, } \\
\text { Oregon grape }\end{array}$ & Well drained & QTba \\
\hline P13 & 541212 & 5027009 & 58 & Douglas fir & Well drained & QTs \\
\hline P14 & 518251 & 5054374 & 6 & Cottonwood, & Well drained & Qal \\
\hline P15 & 541144 & 5039793 & 76 & Douglas fir & Well drained & Qgs \\
\hline P16 & 523521 & 5039058 & 198 & $\begin{array}{c}\text { Maple, } \\
\text { Douglas fir }\end{array}$ & $\begin{array}{l}\text { Moderately- } \\
\text { well drained }\end{array}$ & Qs \\
\hline P17 & 533155 & 5020282 & 73 & Alder, Maple & $\begin{array}{l}\text { Moderately } \\
\text { drained }\end{array}$ & QTs \\
\hline P18 & 533053 & 5020069 & 116 & Alder, Maple & Well drained & QTba \\
\hline $\mathrm{S} 2$ & 491580 & 4976053 & 222 & Oak & Well drained & Tcg \\
\hline S5 & 492013 & 4975464 & 73 & $\begin{array}{c}\text { Maple, } \\
\text { Douglas fir }\end{array}$ & Well drained & Tcg \\
\hline S6 & 491838 & 4977670 & 213 & $\begin{array}{c}\text { Douglas fir, } \\
\text { Maple }\end{array}$ & Well drained & Tcg \\
\hline S7 & 496863 & 4976953 & 6 & $\begin{array}{l}\text { Maple, Alder, } \\
\text { Cottonwood }\end{array}$ & Well drained & Qal \\
\hline S8 & 497483 & 4975055 & 46 & Oak, Grass & Well drained & Qs \\
\hline S9 & 492343 & 4973847 & 43 & $\begin{array}{c}\text { Cottonwood, } \\
\text { Grass }\end{array}$ & Well drained & Qal \\
\hline
\end{tabular}


Appendix C: Site Observations for Phase I(1995) Sites (Ashbaugh, 1995) (Continued) (Descriptions of soils taken at these sites are described in Appendix D: Description of Phase I Soil Samples (Ashbaugh, 1995))

\begin{tabular}{|c|c|c|c|c|c|c|}
\hline Site & $\begin{array}{c}\text { Easting } \\
\text { (UTM } \\
\text { NAD 83) }\end{array}$ & $\begin{array}{c}\text { Northing } \\
\text { (UTM } \\
\text { NAD 83) }\end{array}$ & $\begin{array}{c}\text { Elevation } \\
\mathbf{( m )}\end{array}$ & Vegetation & Drainage & $\begin{array}{c}\text { Underlying } \\
\text { Geologic } \\
\text { Unit }\end{array}$ \\
\hline S10 & 498126 & 4969207 & 131 & Douglas fir & Well drained & Tc \\
\hline S11 & 499150 & 4963674 & 152 & Oak, Grass & Well drained & Tc \\
\hline S12 & 505693 & 4994240 & 55 & $\begin{array}{c}\text { Cottonwood; } \\
\text { Poison oak }\end{array}$ & $\begin{array}{c}\text { Moderately } \\
\text { drained }\end{array}$ & Qs \\
\hline W1 & 519284 & 5025030 & 36 & Grass & Poorly drained & Qal \\
\hline W2 & 518563 & 5022416 & 100 & $\begin{array}{c}\text { Douglas fir, } \\
\text { Spruce }\end{array}$ & Well drained & Tc \\
\hline W3 & 517701 & 5013384 & 55 & Douglas fir & Well drained & Qs \\
\hline W4 & 507600 & 5011319 & 53 & Oak & Well drained & Qs \\
\hline W5 & 457126 & 4993949 & 207 & Douglas fir & Well drained & Ty \\
\hline W6 & 451290 & 4994789 & 134 & Douglas fir & Well drained & Tco \\
\hline W7 & 509234 & 5016806 & 350 & Grass & Well drained & Tc \\
\hline W8 & 512110 & 5019153 & 213 & Douglas fir & Well drained & Tc \\
\hline W9 & 515080 & 5016470 & 49 & Douglas fir & Well drained & Qs \\
\hline
\end{tabular}


Appendix D: Description of Phase I Soil Samples (Ashbaugh, 1995)

Descriptions for the site locations from which these soil samples were taken are found in Appendix C: Site Observations for Phase I (1995) Sites (Ashbaugh, 1995))

\begin{tabular}{|c|c|c|c|c|c|}
\hline Site & Horizon & Depth $(\mathrm{cm})$ & Color & Texture & Structure \\
\hline $\mathrm{C} 1$ & $A$ & $0-5$ & 10YR $5 / 3$ & Loam & $\begin{array}{l}\text { Weak massive, Subangular } \\
\text { blocky }\end{array}$ \\
\hline C1 & $\mathrm{Bt}$ & $5-45$ & 10YR 6/4 & Loam & Subanguar blocky \\
\hline $\mathrm{C} 2$ & A & $0-13$ & 10YR $6 / 2$ & Loam & Massive \\
\hline $\mathrm{C} 2$ & Bw & $13-50$ & 10YR 6/3 & Loam & Massive \\
\hline C3 & $A$ & $0-20$ & 10YR $4 / 3$ & Clay & $\begin{array}{l}\text { Moderately massive, } \\
\text { Subangular blocky }\end{array}$ \\
\hline C3 & Bs & $20-250+$ & 5YR 4/6 & Clay & $\begin{array}{l}\text { Strongly massive, } \\
\text { Subangular blocky }\end{array}$ \\
\hline C4 & A & $0-20$ & 7.5YR 3/4 & Silt Loam & Granular \\
\hline C4 & $\mathrm{Bt}$ & $20-60$ & 10YR 6/6 & $\begin{array}{l}\text { Silty Clay } \\
\text { Loam }\end{array}$ & $\begin{array}{l}\text { Moderately massive, } \\
\text { Subangular blocky }\end{array}$ \\
\hline $\mathrm{C} 5$ & $A$ & $0-5$ & 10YR 4/3 & Sandy Loam & Granular \\
\hline C5 & Bw & $13-50$ & 10YR 6/4 & $\begin{array}{l}\text { Sandy Clay } \\
\text { Loam }\end{array}$ & $\begin{array}{l}\text { Weakly massive, } \\
\text { Subangular blocky }\end{array}$ \\
\hline C6 & A & $0-5$ & 10YR $5 / 3$ & Silty Loam & Granular \\
\hline C6 & $\mathrm{Bt}$ & $10-45$ & 10YR 6/4 & Clay Loam & $\begin{array}{l}\text { Moderately massive, } \\
\text { Subangular blocky }\end{array}$ \\
\hline $\mathrm{C7}$ & $A$ & $0-5$ & 10YR $4 / 3$ & Sandy Loam & $\begin{array}{l}\text { Weakly massive, } \\
\text { Subangular blocky }\end{array}$ \\
\hline $\mathrm{C7}$ & $\mathrm{Bt}$ & $5-50$ & 10YR $5 / 3$ & $\begin{array}{l}\text { Sandy Clay } \\
\text { Loam }\end{array}$ & $\begin{array}{l}\text { Moderately massive, } \\
\text { Subangular blocky }\end{array}$ \\
\hline C8 & $A$ & $0-25$ & 10YR $3 / 3$ & $\begin{array}{c}\text { Gravelly } \\
\text { Sandy Loam }\end{array}$ & $\begin{array}{l}\text { Weakly massive, } \\
\text { Subangular blocky }\end{array}$ \\
\hline $\mathrm{C} 8$ & $\mathrm{Bt}$ & $25-50$ & 10YR $4 / 3$ & $\begin{array}{c}\text { Gravelly } \\
\text { Sandy Loam }\end{array}$ & $\begin{array}{l}\text { Moderately massive, } \\
\text { Subangular blocky }\end{array}$ \\
\hline C9 & $A$ & $0-50$ & 10YR $3 / 3$ & $\begin{array}{c}\text { Gravelly } \\
\text { Sandy Loam }\end{array}$ & $\begin{array}{l}\text { Weakly massive, } \\
\text { Subangular blocky }\end{array}$ \\
\hline C9 & Bw & $50-80$ & 10YR 4/3 & $\begin{array}{c}\text { Gravelly } \\
\text { Sandy Loam }\end{array}$ & $\begin{array}{l}\text { Moderately massive, } \\
\text { Subangular blocky }\end{array}$ \\
\hline C10 & A & $0-12$ & 10YR $2 / 2$ & Silty Loam & Subangular blocky \\
\hline C10 & $\mathrm{Bt}$ & $12-45$ & 10YR 4/4 & Clay Loam & Subangular blocky \\
\hline C11 & A & $0-10$ & 10YR $2 / 2$ & Loamy Sand & Granular, Massive \\
\hline C11 & Bw & $10-55$ & 10YR 4/4 & Sandy Loam & $\begin{array}{c}\text { Weakly-moderately } \\
\text { massive, Subangular blocky }\end{array}$ \\
\hline
\end{tabular}


Appendix D: Description of Phase I Soil Samples (Ashbaugh, 1995) (Continued) Descriptions for the site locations from which these soil samples were taken are found in Appendix C: Site Observations for Phase I (1995) Sites (Ashbaugh, 1995))

\begin{tabular}{|c|c|c|c|c|c|}
\hline Site & Horizon & Depth (cm) & Color & Texture & Structure \\
\hline $\mathrm{C} 12$ & $A$ & $0-5$ & 10YR $2 / 2$ & Sandy Loam & $\begin{array}{l}\text { Weakly massive, } \\
\text { Subangular blocky }\end{array}$ \\
\hline C12 & Bw & $5-35$ & 10YR $2 / 2$ & Sandy Loam & $\begin{array}{c}\text { Weaky massive, Subangular } \\
\text { blocky }\end{array}$ \\
\hline C13 & A & $0-25$ & 10YR 4/3 & Sandy Loam & Granular, Massive \\
\hline C13 & Bw & $25-50$ & 10YR 4/5 & Clay Loam & $\begin{array}{l}\text { Moderately massive, } \\
\text { Subangular blocky }\end{array}$ \\
\hline C14 & $A$ & $0-20$ & 10YR 6/6 & Silty Loam & Granular, Massive \\
\hline C14 & $\mathrm{Bw}$ & $20-60$ & 10YR $4 / 3$ & $\begin{array}{l}\text { Silty Clay } \\
\text { Loam }\end{array}$ & $\begin{array}{l}\text { Moderately massive, } \\
\text { Subangular blocky }\end{array}$ \\
\hline C15 & $A$ & $0-30$ & 10YR 6/3 & Sandy Loam & Granular,Massive \\
\hline C15 & Bw & $30-80$ & 10YR 6/4 & Sandy Loam & $\begin{array}{l}\text { Moderately massive, } \\
\text { Subangular blocky }\end{array}$ \\
\hline C16 & $A$ & $0-25$ & 7.5YR 6/4 & $\begin{array}{l}\text { Silty Clay } \\
\text { Loam }\end{array}$ & Granular, Massive \\
\hline C16 & $\mathrm{Bt}$ & $25-100$ & 7.5YR 6/5 & $\begin{array}{l}\text { Silty Clay } \\
\text { Loam }\end{array}$ & $\begin{array}{l}\text { Moderately massive, } \\
\text { Subangular blocky }\end{array}$ \\
\hline M1 & $A$ & & $7.5 Y R 6 / 2$ & Sandy Loam & Granular, Single grain \\
\hline M1 & $\mathrm{Bw}$ & 45 & 10YR 5/4 & Loamy Sand & Granular, Single grain \\
\hline $\mathrm{M} 2$ & $A$ & $0-8$ & $2.5 Y R 5 / 2$ & Loamy Sand & Granular, Single grain \\
\hline $\mathrm{M} 2$ & $\mathrm{Bw}$ & $15-37$ & 10YR 4/3 & Sandy Loam & Granular, Single grain \\
\hline M3 & A & $0-5$ & 5YR 3/1 & Loamy Sand & Granular, Single grain \\
\hline M3 & $\mathrm{Bw}$ & $5-25$ & 7.5YR 6/2 & Sandy Loam & Massive \\
\hline M4 & $A$ & $0-8$ & $7.5 Y R 3 / 4$ & Loamy Sand & Granular, Single grain \\
\hline M4 & $\mathrm{Bt}$ & $8-60$ & 10YR 6/4 & Loamy Sand & Massive \\
\hline M5 & $A$ & $0-15$ & 10YR 5/2 & Loamy Sand & Granular, Single grain \\
\hline M5 & $\mathrm{Bw}$ & $15-45$ & 10YR 6/3 & Sandy Loam & Granular, Single grain \\
\hline M6 & $A$ & $0-20$ & 10YR 4/1 & Loamy Sand & Granular, Single grain \\
\hline M6 & $\mathrm{Bw}$ & $20-50$ & 10YR 6/4 & Loamy Sand & Granular, Single grain \\
\hline M7 & $A$ & $0-5$ & 10YR 3/1 & Loamy Sand & Granular, Single grain \\
\hline M7 & $\mathrm{Bt}$ & $5-30$ & 10YR 6/4 & Sandy Loam & Granular, Single grain \\
\hline $\mathrm{M} 8$ & A & $0-15$ & 10YR 4/2 & Loamy Sand & Granular, Single grain \\
\hline M8 & $\mathrm{Bt}$ & $15-30$ & 10YR 4/2 & Loamy Sand & Granular, Single grain \\
\hline
\end{tabular}


Appendix D: Description of Phase I Soil Samples (Ashbaugh, 1995) (Continued)

Descriptions for the site locations from which these soil samples were taken are found in Appendix C: Site Observations for Phase I (1995) Sites (Ashbaugh, 1995))

\begin{tabular}{|c|c|c|c|c|c|}
\hline Site & Horizon & Depth (cm) & Color & Texture & Structure \\
\hline M9 & $A$ & $0-10$ & $10 Y R 4 / 3$ & $\begin{array}{l}\text { Sandy Clay } \\
\text { Loam }\end{array}$ & Granular, Single grain \\
\hline M9 & $\mathrm{Bt}$ & $10-30$ & 10YR $4 / 2$ & $\begin{array}{l}\text { Sandy Clay } \\
\text { Loam }\end{array}$ & $\begin{array}{l}\text { Weakly massive, } \\
\text { Subangular blocky }\end{array}$ \\
\hline M10 & A & $0-10$ & 10YR 4/3 & Loamy Sand & Granular, Single grain \\
\hline M10 & Bw & $10-30$ & 10YR 5/2 & Sandy Loam & Massive \\
\hline M11 & $A$ & $0-17$ & 10YR $6 / 3$ & $\begin{array}{c}\text { Silty Clay } \\
\text { Loam }\end{array}$ & $\begin{array}{l}\text { Weakly massive, } \\
\text { Subangular blocky }\end{array}$ \\
\hline M11 & $\mathrm{Bt}$ & $17-30$ & 10YR $7 / 2$ & $\begin{array}{l}\text { Silty Clay } \\
\text { Loam }\end{array}$ & $\begin{array}{l}\text { Weakly massive, } \\
\text { Subangular blocky }\end{array}$ \\
\hline M12 & $A$ & $0-17$ & 10YR 5/4 & $\begin{array}{c}\text { Sandy Clay } \\
\text { Loam }\end{array}$ & Granular, Single grain \\
\hline M12 & $\mathrm{Bt}$ & $17-35$ & 10YR 4/4 & Clay Loam & Granular, Single grain \\
\hline M13 & $A$ & $0-15$ & 10YR 6/3 & $\begin{array}{l}\text { Sandy Clay } \\
\text { Loam }\end{array}$ & Granular, Single grain \\
\hline M13 & $\mathrm{Bt}$ & $15-35$ & 10YR 6/2 & $\begin{array}{l}\text { Sandy Clay } \\
\text { Loam }\end{array}$ & $\begin{array}{l}\text { Moderately massive, } \\
\text { Subangular blocky }\end{array}$ \\
\hline M14 & $A$ & $0-5$ & 5YR 4/2 & Clay & Granular, Single grain \\
\hline M14 & $\mathrm{Bt}$ & $5-30$ & $5 Y R 3 / 3$ & Clay & $\begin{array}{l}\text { Strongly massive, } \\
\text { Subangular blocky }\end{array}$ \\
\hline M15 & $A$ & $0-15$ & 10YR 6/2 & $\begin{array}{l}\text { Silty Clay } \\
\text { Loam }\end{array}$ & $\begin{array}{l}\text { Weakly massive, } \\
\text { Subangular blocky }\end{array}$ \\
\hline M15 & $\mathrm{Bt}$ & $15-35$ & 10YR 6/2 & $\begin{array}{l}\text { Silty Clay } \\
\text { Loam }\end{array}$ & $\begin{array}{c}\text { Moderately massive, } \\
\text { Subangular blocky }\end{array}$ \\
\hline M16 & $A$ & $0-17$ & 10YR 5/4 & $\begin{array}{c}\text { Sandy Clay } \\
\text { Loam }\end{array}$ & $\begin{array}{l}\text { Weakly massive, } \\
\text { Subangular blocky }\end{array}$ \\
\hline M16 & $\mathrm{Bt}$ & $17-35$ & 10YR 4/4 & $\begin{array}{c}\text { Sandy Clay } \\
\text { Loam }\end{array}$ & $\begin{array}{c}\text { Moderately massive, } \\
\text { Subangular blocky }\end{array}$ \\
\hline M17 & $A$ & $0-10$ & $10 Y R 5 / 3$ & Sandy Loam & Granular, Single grain \\
\hline M17 & $\mathrm{Bt}$ & $10-35$ & 7.5YR 4/3 & Sandy Loam & Granular, Single grain \\
\hline M18 & $A$ & $0-5$ & 7.5YR 4/2 & Loamy Sand & Granular, Single grain \\
\hline M18 & $\mathrm{Bw}$ & $10-35$ & $7.5 Y R 5 / 2$ & Loamy Sand & Granular, Single grain \\
\hline
\end{tabular}


Appendix D: Description of Phase I Soil Samples (Ashbaugh, 1995) (Continued)

Descriptions for the site locations from which these soil samples were taken are found in Appendix C: Site Observations for Phase I (1995) Sites (Ashbaugh, 1995))

\begin{tabular}{|c|c|c|c|c|c|}
\hline Site & Horizon & Depth $(\mathrm{cm})$ & Color & Texture & Structure \\
\hline M19 & $A$ & $0-3$ & $7.5 Y R 4 / 3$ & Loamy Sand & Granular, Single grain \\
\hline M19 & $\mathrm{Bt}$ & $5-35$ & 7.5YR 5/2 & Sandy Loam & $\begin{array}{l}\text { Weakly massive, } \\
\text { Subangular blocky }\end{array}$ \\
\hline $\mathrm{M} 20$ & A & $0-5$ & $10 Y R 3 / 3$ & Loamy Sand & Granular, Single grain \\
\hline $\mathrm{M} 20$ & $\mathrm{Bt}$ & $5-40$ & 10YR 5/6 & Loamy Sand & Granular, Single grain \\
\hline $\mathrm{M} 21$ & A & $0-5$ & $7.5 Y R 5 / 3$ & Loamy Sand & Granular, Single grain \\
\hline $\mathrm{M} 21$ & $\mathrm{Bt}$ & $5-40$ & 10YR 5/6 & Loamy Sand & Granular, Single grain \\
\hline $\mathrm{M} 22$ & A & $0-8$ & 10YR 4/3 & Loamy Sand & Granular, Single grain \\
\hline $\mathrm{M} 22$ & $\mathrm{Bt}$ & $8-50$ & 10YR 6/6 & Loamy Sand & Granular, Single grain \\
\hline M23 & $A$ & $0-3$ & $10 Y R 3 / 3$ & Loamy Sand & Granular, Single grain \\
\hline $\mathrm{M} 23$ & Bw & $3-40$ & 10YR 4/3 & Loamy Sand & Granular, Single grain \\
\hline M24 & $A$ & $0-5$ & 10YR $3 / 3$ & Loamy Sand & Granular, Single grain \\
\hline M24 & $\mathrm{Bt}$ & $20-50$ & 10YR 4/3 & Loamy Sand & Granular, Single grain \\
\hline P1 & Bw & $15-45$ & 10YR 6/2 & Silty Loam & $\begin{array}{l}\text { Weakly massive, } \\
\text { Subangular blocky }\end{array}$ \\
\hline P2 & $\operatorname{Cox}(B)$ & $25-37$ & $5 Y R 3 / 2$ & $\begin{array}{c}\text { Gravelly } \\
\text { Sandy Loam }\end{array}$ & Massive \\
\hline P3 & B & $10-15$ & 10YR 6/6 & $\begin{array}{c}\text { Gravelly } \\
\text { Sandy Loam }\end{array}$ & $\begin{array}{l}\text { Moderately massive, } \\
\text { Subangular blocky }\end{array}$ \\
\hline P4 & B & $25-37$ & 10YR 5/4 & Silty Loam & $\begin{array}{l}\text { Weakly massive, } \\
\text { Subangular blocky }\end{array}$ \\
\hline P5 & B & $30-45$ & 10YR 6/4 & Silty Loam & $\begin{array}{c}\text { Moderately massive, } \\
\text { Subangular blocky }\end{array}$ \\
\hline P6 & A & $0-25$ & 10YR 3/3 & Silty Loam & Granular, Massive \\
\hline P6 & Bw & $25-45$ & 10YR 5/3 & Silty Loam & $\begin{array}{l}\text { Weakly massive, } \\
\text { Subangular blocky }\end{array}$ \\
\hline $\mathrm{P7}$ & $\mathrm{A}$ & $0-20$ & 10YR $3 / 3$ & Silty Loam & Granular \\
\hline P7 & Bw & $20-50$ & 10YR 503 & Silty Loam & $\begin{array}{l}\text { Weakly massive, } \\
\text { Subangular blocky }\end{array}$ \\
\hline P8 & $A$ & $0-20$ & $5 Y R 3 / 3$ & $\begin{array}{c}\text { Silty Clay } \\
\text { Loam }\end{array}$ & Granular, Massive \\
\hline P8 & Bw & $20-45$ & $7.5 Y R 4 / 6$ & Clay Loam & $\begin{array}{c}\text { Moderately massive, } \\
\text { Subangular blocky }\end{array}$ \\
\hline
\end{tabular}


Appendix D: Description of Phase I Soil Samples (Ashbaugh, 1995) (Continued) Descriptions for the site locations from which these soil samples were taken are found in Appendix C: Site Observations for Phase I (1995) Sites (Ashbaugh, 1995))

\begin{tabular}{|c|c|c|c|c|c|}
\hline Site & Horizon & Depth (cm) & Color & Texture & Structure \\
\hline P9 & $A$ & $0-20$ & $5 Y R 3 / 3$ & $\begin{array}{l}\text { Silty Clay } \\
\text { Loam }\end{array}$ & Granular, Massive \\
\hline P9 & $\mathrm{Bt}$ & $20-50$ & 7.5YR 5/8 & Clay Loam & $\begin{array}{l}\text { Moderately massive, } \\
\text { Subangular blocky }\end{array}$ \\
\hline P10 & $A$ & $0-30$ & 10YR $5 / 3$ & $\begin{array}{l}\text { Silty Clay } \\
\text { Loam }\end{array}$ & Granular, Single grain \\
\hline P10 & $\mathrm{Bt}$ & $30-75$ & 10YR 6/4 & $\begin{array}{l}\text { Gravelly Silty } \\
\text { Clay Loam }\end{array}$ & Skeletal \\
\hline P11 & $\mathrm{A}$ & $0-8$ & 10YR 4/3 & Sandy Loam & Granular, Single grain \\
\hline P11 & $C(B)$ & $8-30$ & 10YR 6/3 & Sand & Granular, Single grain \\
\hline P12 & $A$ & $0-10$ & $10 Y R 3 / 3$ & $\begin{array}{l}\text { Silty Sandy } \\
\text { Loam }\end{array}$ & Massive \\
\hline P12 & Bw & $10-35$ & 10YR $4 / 3$ & $\begin{array}{l}\text { Silty Sandy } \\
\text { Loam }\end{array}$ & Massive \\
\hline P13 & $A$ & $0-12$ & $7.5 Y R 3 / 3$ & $\begin{array}{l}\text { Silty Sandy } \\
\text { Loam }\end{array}$ & Granular, Single grain \\
\hline P13 & Bw & $12-35$ & 10YR $6 / 3$ & $\begin{array}{l}\text { Gravelly Silty } \\
\text { Sandy Loam }\end{array}$ & Skeletal \\
\hline P14 & $A$ & $0-15$ & $10 Y R 3 / 3$ & Loamy Sand & Granular, Single grain \\
\hline P14 & $C(B)$ & $15-40$ & $2.5 Y R 6 / 3$ & Samd & Granular, Single grain \\
\hline P15 & $A$ & $0-20$ & 10YR $2 / 2$ & Loamy Sand & Granular, Single grain \\
\hline P15 & $\mathrm{Bt}$ & $20-45$ & 10YR 6/6 & $\begin{array}{l}\text { Gravelly, Silty } \\
\text { Sandy Loam }\end{array}$ & Skeletal \\
\hline P16 & $A$ & $0-20$ & 10YR 5/2 & Silty Loam & Granular, Single grain \\
\hline P16 & $\mathrm{Bt}$ & $20-50$ & 10YR 6/4 & Silty Loam & $\begin{array}{l}\text { Moderately massive, } \\
\text { Subangular blocky }\end{array}$ \\
\hline P17 & $A$ & $0-30$ & 10YR $6 / 2$ & Silty Loam & Granular \\
\hline P17 & Bw & $30-75$ & 10YR $7 / 2$ & Silty Loam & $\begin{array}{l}\text { Weakly massive, } \\
\text { Subangular blocky }\end{array}$ \\
\hline $\mathrm{P} 18$ & $\mathrm{~A}$ & $0-20$ & $7.5 Y R 3 / 3$ & Clay Loam & Granular, Massive \\
\hline P18 & $\mathrm{Bt}$ & $20-100$ & $7.5 Y R 5 / 6$ & Clay Loam & Granular, Massive \\
\hline $\mathrm{S} 2$ & $\mathrm{~A}$ & $0-20$ & $7.5 Y R 4 / 3$ & Loam & Granular, Massive \\
\hline S2 & Bw & $20-35$ & 7.5YR 4/4 & $\begin{array}{l}\text { Gravelly, } \\
\text { Loam }\end{array}$ & Skeletal \\
\hline
\end{tabular}




\section{Appendix D: Description of Phase I Soil Samples (Ashbaugh, 1995) (Continued)}

Descriptions for the site locations from which these soil samples were taken are found in Appendix C: Site Observations for Phase I (1995) Sites (Ashbaugh, 1995))

\begin{tabular}{|c|c|c|c|c|c|}
\hline Site & Horizon & Depth $(\mathrm{cm})$ & Color & Texture & Structure \\
\hline S5 & A & $0-30$ & 10YR 4/3 & Clay Loam & Granular, Massive \\
\hline S5 & Bw & $30-65$ & 10YR 5/3 & Clay Loam & $\begin{array}{l}\text { Weakly massive, } \\
\text { Subangular blocky }\end{array}$ \\
\hline S6 & A & $0-30$ & 7.5YR 4/4 & Clay Loam & $\begin{array}{l}\text { Weakly massive, } \\
\text { Subangular blocky }\end{array}$ \\
\hline S6 & $\mathrm{Bt}$ & $30-45$ & 7.5YR 4/6 & Clay Loam & $\begin{array}{l}\text { Weakly massive, } \\
\text { Subangular blocky }\end{array}$ \\
\hline S7 & $\mathrm{A}$ & $0-15$ & 10YR 5/2 & Loamy Sand & Granular, massive \\
\hline S7 & $C(B)$ & $15-25$ & 10YR 5/2 & Sand & Granular, Single grain \\
\hline S8 & $A$ & $0-8$ & 10YR $5 / 3$ & Sandy Loam & Granular, Massive \\
\hline S8 & Bw & $8-35$ & 10YR 6/3 & $\begin{array}{c}\text { Gravelly } \\
\text { Sandy Loam }\end{array}$ & Skeletal \\
\hline S9 & A & $0-20$ & $10 Y R 5 / 3$ & Sandy Loam & Granular, Massive \\
\hline S9 & $C(B)$ & $20-30$ & 10YR 5/2 & Sand & Granular, Massive \\
\hline S10 & A & $0-15$ & 7.5YR 4/4 & Clay Loam & $\begin{array}{l}\text { Weakly massive, } \\
\text { Subangular blocky }\end{array}$ \\
\hline S10 & $\mathrm{Bt}$ & $15-600$ & $\begin{array}{c}7.5 Y R \text { 5/4 } \\
\text { Clay }\end{array}$ & Clay & $\begin{array}{l}\text { Strongly massive, } \\
\text { Subangular blocky }\end{array}$ \\
\hline S11 & A & $0-15$ & $5 Y R 4 / 3$ & Clay Loam & Granular, Massive \\
\hline S11 & $\mathrm{Bt}$ & $12-600$ & 5YR 5/6 & Clay & $\begin{array}{l}\text { Strongly massive, } \\
\text { Subangular blocky }\end{array}$ \\
\hline S12 & $\mathrm{A}$ & $0-5$ & 10YR 6/2 & Silty Loam & Granular, Massive \\
\hline S12 & Bw & $5-35$ & 10YR 6/3 & Silty Loam & Granular, Massive \\
\hline W1 & $\mathrm{A}$ & $0-25$ & 10YR 4/2 & Silty Loam & Granular, Massive \\
\hline W1 & $\mathrm{Bg}$ & $25-35$ & 10YR 5/2 & Silty Clay & $\begin{array}{l}\text { Moderately massive, } \\
\text { Subangular blocky }\end{array}$ \\
\hline W2 & A & $0-22$ & 10YR $5 / 2$ & Loam & $\begin{array}{l}\text { Weakly massive, } \\
\text { Subangular blocky }\end{array}$ \\
\hline W2 & B & $22-45$ & 10YR 5/4 & Silty Clay & $\begin{array}{c}\text { Moderately massive, } \\
\text { Subangular blocky }\end{array}$ \\
\hline W3 & A & $0-25$ & 10YR 5/3 & Silty Loam & Granular, Massive \\
\hline W3 & Bw & $25-60$ & 10YR $5 / 4$ & $\begin{array}{l}\text { Silty Clay } \\
\text { Loam }\end{array}$ & $\begin{array}{l}\text { Weakly massive, } \\
\text { Subangular blocky }\end{array}$ \\
\hline
\end{tabular}


Appendix D: Description of Phase I Soil Samples (Ashbaugh, 1995) (Continued)

Descriptions for the site locations from which these soil samples were taken are found in Appendix C: Site Observations for Phase I (1995) Sites (Ashbaugh, 1995))

\begin{tabular}{|c|c|c|c|c|c|}
\hline Site & Horizon & Depth $(\mathrm{cm})$ & Color & Texture & Structure \\
\hline W4 & $A$ & $0-30$ & 10YR 5/2 & Loam & Granular \\
\hline W4 & Bw & $30-45$ & 10YR 5/2 & $\begin{array}{l}\text { Silty clay } \\
\text { Loam }\end{array}$ & $\begin{array}{l}\text { Weakly massive, } \\
\text { Subangular blocky }\end{array}$ \\
\hline W5 & $A$ & $0-40$ & 10YR 4/3 & Loam & Granular \\
\hline W5 & $\mathrm{Bt}$ & $40-55$ & 10YR 4/6 & Clay & $\begin{array}{c}\text { Moderately massive, } \\
\text { Subangular blocky }\end{array}$ \\
\hline W6 & A & $0-22$ & 10YR 6/4 & Silty Clay & Granular, Massive \\
\hline W6 & BC & $22-30$ & 10YR 6/3 & Clay & $\begin{array}{c}\text { Moderately massive, } \\
\text { Subangular blocky }\end{array}$ \\
\hline W7 & A & $0-60$ & $7.5 Y R 4 / 4$ & $\begin{array}{l}\text { Silty Clay } \\
\text { Loam }\end{array}$ & Granular, massive \\
\hline W7 & $\mathrm{Bt}$ & $60-120$ & 7.5YR 5/6 & Clay & $\begin{array}{l}\text { Strongly massive, } \\
\text { Subangular blocky }\end{array}$ \\
\hline W8 & A & $0-45$ & 7.5YR 5/4 & $\begin{array}{l}\text { Silty Clay } \\
\text { Loam }\end{array}$ & Granular, Massive \\
\hline W8 & $\mathrm{Bt}$ & $45-150$ & 7.5YR 5/4 & Clay & $\begin{array}{l}\text { Strongly massive, } \\
\text { Subangular blocky }\end{array}$ \\
\hline W9 & $A$ & $0-20$ & $10 Y R 5 / 3$ & Silty Loam & Granular, Massive \\
\hline W9 & Bw & $20-50$ & 10YR 6/3 & $\begin{array}{l}\text { Silty clay } \\
\text { Loam }\end{array}$ & Granular, Massive \\
\hline
\end{tabular}


Appendix E: Site Observations for Phase II (2010) Sites

(Descriptions of soils taken at these sites are described in Appendix F: Description of Phase II Soil Samples (2010). Photos of sites are included in Appendix G: Site and Soil Pit Images from Sites Sampled During Phase II Sampling (2010))

\begin{tabular}{|c|c|c|c|c|c|c|}
\hline Site & $\begin{array}{l}\text { Easting } \\
\text { (UTM } \\
\text { NAD 83) }\end{array}$ & $\begin{array}{l}\text { Northing } \\
\text { (UTM } \\
\text { NAD 83) }\end{array}$ & Vegetation & $\begin{array}{c}\text { Elevation } \\
\text { (by GPS) }\end{array}$ & $\begin{array}{c}\text { Drainage } \\
\text { Note }\end{array}$ & $\begin{array}{l}\text { Underlying } \\
\text { Geologic Unit }\end{array}$ \\
\hline TR1 & 532794 & 5020289 & Maple, Alder & 509 & well drained & QTb \\
\hline TR2 & 538370 & 5032348 & $\begin{array}{c}\text { Douglas Fir, } \\
\text { Hazelnut, } \\
\text { Ferns }\end{array}$ & 569 & well drained & QTb \\
\hline TR3 & 478253 & 5055388 & $\begin{array}{l}\text { Douglas Fir, } \\
\text { Cedar, Maple }\end{array}$ & 205 & well drained & $\mathrm{Ti}$ \\
\hline TR4 & 476365 & 5055716 & $\begin{array}{c}\text { Douglas Fir, } \\
\text { Maple, }\end{array}$ & 560 & well drained & $\mathrm{Ti}$ \\
\hline TR5 & 432411 & 5019746 & $\begin{array}{c}\text { Alder, } \\
\text { Douglas Fir }\end{array}$ & 253 & well drained & Tsd \\
\hline TR6 & 429312 & 5018963 & $\begin{array}{l}\text { Western } \\
\text { Hemlock, }\end{array}$ & 226 & Good & Tsd \\
\hline TR7 & 425260 & 4990592 & $\begin{array}{l}\text { Western } \\
\text { Hemlock, }\end{array}$ & 785.3 & well drained & Tpb \\
\hline TR8 & 424371 & 4992681 & $\begin{array}{c}\text { Western } \\
\text { Hemlock; } \\
\text { Douglas Fir }\end{array}$ & 137.8 & well drained & $\mathrm{Tpb}$ \\
\hline TR9 & 518803 & 4914773 & $\begin{array}{c}\text { Douglas Fir, } \\
\text { berries }\end{array}$ & 207 & well drained & Tub \\
\hline TR10 & 518782 & 4914988 & $\begin{array}{c}\text { Douglas Fir, } \\
\text { Maple }\end{array}$ & 276 & well drained & Tub \\
\hline TR11 & 555775 & 4916836 & Douglas Fir, & 1415 & well drained & Tus \\
\hline TR12 & 560076 & 4915917 & Douglas Fir & & well drained & Tus \\
\hline TR13 & 575374 & 4896162 & Douglas Fir, & & well drained & Tfc \\
\hline TR14 & 575103 & 4898916 & Douglas Fir & 1929 & well drained & TfC \\
\hline
\end{tabular}


Appendix E: Site Observations for Phase II (2010) Sites (Continued)

(Descriptions of soils taken at these sites are described in Appendix F: Description of Phase II Soil Samples (2010). Photos of sites are included in Appendix G: Site and Soil Pit Images from Sites Sampled During Phase II Sampling (2010)

\begin{tabular}{|c|c|c|c|c|c|c|}
\hline Site & $\begin{array}{c}\text { Easting } \\
\text { (UTM } \\
\text { NAD 83) }\end{array}$ & $\begin{array}{c}\text { Northing } \\
\text { (UTM } \\
\text { NAD 83) }\end{array}$ & Vegetation & $\begin{array}{c}\text { Elevation } \\
\text { (by GPS) }\end{array}$ & $\begin{array}{c}\text { Drainage } \\
\text { Note }\end{array}$ & $\begin{array}{c}\text { Underlying } \\
\text { Geologic } \\
\text { Unit }\end{array}$ \\
\hline TR15 & 582877 & 4921228 & Douglas Fir, & 3700 & well drained & Qg \\
\hline TR16 & 580184 & 4925531 & Douglas Fir & 3817 & well drained & Qg \\
\hline TR17 & 579650 & 4930556 & $\begin{array}{c}\text { Hemlock, } \\
\text { Douglas Fir }\end{array}$ & 3158 & well drained & Tbaa \\
\hline TR18 & 580593 & 4937061 & $\begin{array}{c}\text { Douglas Fir, } \\
\text { Western } \\
\text { Hemlock, } \\
\text { Rhododendron, } \\
\text { Huckleberry }\end{array}$ & 2678 & well drained & Tbaa \\
\hline
\end{tabular}




\section{Appendix F: Description of Phase II Soil Samples (2010)}

Descriptions for the site locations from which these soil samples were taken are found in Appendix F: Description of Phase II Soil Samples (2010). Photos of these soil pits are included in Appendix G: Site and Soil Pit Images from Sites Sampled During Phase II Sampling (2010))

\begin{tabular}{|c|c|c|c|c|c|c|}
\hline Site & Horizon & $\begin{array}{l}\text { Depth } \\
\text { (cm) }\end{array}$ & Color & Texture & Clay \% & Structure \\
\hline TR1 & $A$ & 3 & 7.5YR 4.6 & $\begin{array}{l}\text { Heavy Sandy } \\
\text { Clay Loam }\end{array}$ & 30 & Subangular Blocky \\
\hline TR1 & $\mathrm{Bt}$ & 22 & 5YR 4/6 & $\begin{array}{l}\text { Sandy Clay } \\
\text { Loam }\end{array}$ & 50 & Subangular Blocky \\
\hline TR2 & $A$ & 3 & $5 Y R 3 / 2$ & Silt Loam & 15 & Subangular Blocky \\
\hline TR2 & Bw & 12.5 & 7.5 YR $5 / 3$ & Silt Loam & 25 & $\begin{array}{c}\text { Weak Subangular } \\
\text { Blocky }\end{array}$ \\
\hline TR3 & $A$ & 8 & 10YR 4/3 & Sandy Loam & 10 & $\begin{array}{c}\text { Weak Subangular } \\
\text { Blocky }\end{array}$ \\
\hline TR3 & Bw & 35 & 10YR 4/6 & Sandy Loam & 15 & $\begin{array}{c}\text { Weak Subangular } \\
\text { Blocky }\end{array}$ \\
\hline TR4 & $A$ & 10 & 10YR $4 / 3$ & Sandy Loam & 8 & $\begin{array}{c}\text { Weak Subangular } \\
\text { Blocky }\end{array}$ \\
\hline TR4 & Bw & 45 & 10YR 3/4 & Sandy Loam & 12 & $\begin{array}{c}\text { Weak Subangular } \\
\text { Blocky }\end{array}$ \\
\hline TR5 & $A$ & 5 & 10YR $4 / 4$ & $\begin{array}{l}\text { Fine Sandy } \\
\text { Loam }\end{array}$ & 10 & $\begin{array}{c}\text { Weak Subangular } \\
\text { Blocky }\end{array}$ \\
\hline TR5 & Bw & 35 & 10YR 6/8 & $\begin{array}{l}\text { Fine Sandy } \\
\text { Loam }\end{array}$ & 18 & $\begin{array}{c}\text { Weak Subangular } \\
\text { Blocky }\end{array}$ \\
\hline TR6 & $A$ & 6 & 10YR $2 / 2$ & Sandy Loam & 5 & $\begin{array}{c}\text { Weak Subangular } \\
\text { Blocky }\end{array}$ \\
\hline TR6 & Bw & 40 & 10YR 4/4 & Sandy Loam & 15 & $\begin{array}{c}\text { Weak Subangular } \\
\text { Blocky }\end{array}$ \\
\hline TR7 & $A$ & 10 & $5 Y R 3 / 2$ & Sandy Loam & 5 & $\begin{array}{c}\text { Weak Subangular } \\
\text { Blocky }\end{array}$ \\
\hline TR7 & Bw & 32.5 & $2.5 Y R 3 / 3$ & Sandy Loam & 12 & $\begin{array}{c}\text { Weak Subangular } \\
\text { Blocky }\end{array}$ \\
\hline
\end{tabular}




\section{Appendix F: Description of Phase II Soil Samples (2010) (Continued)}

Descriptions for the site locations from which these soil samples were taken are found in Appendix F: Description of Phase II Soil Samples (2010). Photos of these soil pits are included in Appendix G: Site and Soil Pit Images from Sites Sampled During Phase II Sampling (2010))

\begin{tabular}{|c|c|c|c|c|c|c|}
\hline Site & Horizon & $\begin{array}{l}\text { Depth } \\
\text { (cm) }\end{array}$ & Color & Texture & Clay \% & Structure \\
\hline TR8 & $A$ & 15 & 10YR $2 / 2$ & Sandy Loam & 5 & $\begin{array}{c}\text { Weak Subangular } \\
\text { Blocky }\end{array}$ \\
\hline TR8 & Bw & 30 & $10 Y R 3 / 3$ & Sandy Loam & 15 & $\begin{array}{c}\text { Weak Subangular } \\
\text { Blocky }\end{array}$ \\
\hline TR9 & A & 2 & 10YR 5/4 & Sandy Loam & 10 & $\begin{array}{c}\text { Moderate Subangular } \\
\text { Blocky }\end{array}$ \\
\hline TR9 & $\mathrm{Bt}$ & 5 & $7.5 Y R 5 / 3$ & $\begin{array}{l}\text { Sandy Clay } \\
\text { Loam }\end{array}$ & 30 & $\begin{array}{c}\text { Well Developed } \\
\text { Subangular Blocky }\end{array}$ \\
\hline TR10 & A & 2 & 7.5YR 4/2 & Sandy Loam & 10 & $\begin{array}{c}\text { Moderate Subangular } \\
\text { Blocky }\end{array}$ \\
\hline TR10 & $\mathrm{Bt}$ & 40 & $7.5 Y R 4 / 2$ & $\begin{array}{l}\text { Sandy Clay } \\
\text { Loam }\end{array}$ & 30 & Well Dev SBK \\
\hline TR11 & A & 15 & 10YR $4 / 2$ & Sandy Loam & 5 & Weak Subangular Blocky \\
\hline TR11 & Bw & 55 & 10YR 5/4 & Sandy Loam & 12 & Weak Subangular Blocky \\
\hline TR12 & A & 12 & $10 Y R 4 / 3$ & Sandy Loam & 5 & Weak Subangular Blocky \\
\hline TR12 & Bw & 45 & $10 Y R 5 / 3$ & Sandy Loam & 12 & Weak Subangular Blocky \\
\hline TR13 & A & 8 & $10 Y R 3 / 3$ & Sandy Loam & 5 & Weak Subangular Blocky \\
\hline TR13 & Bw & 32.5 & 10YR 4/4 & Sandy Loam & 12 & Weak Subangular Blocky \\
\hline
\end{tabular}




\section{Appendix F: Description of Phase II Soil Samples (2010) (Continued)}

Descriptions for the site locations from which these soil samples were taken are found in Appendix F: Description of Phase II Soil Samples (2010). Photos of these soil pits are included in Appendix G: Site and Soil Pit Images from Sites Sampled During Phase II Sampling (2010))

\begin{tabular}{|c|c|c|c|c|c|l|}
\hline Site & Horizon & $\begin{array}{c}\text { Depth } \\
(\mathbf{c m})\end{array}$ & Color & Texture & Clay \% & Structure \\
\hline TR14 & A & 8 & 10 YR 3/3 & Sandy Loam & 5 & Weak Subangular Blocky \\
\hline TR14 & Bw & 45 & 10 YR 6/4 & Sandy Loam & 12 & Weak Subangular Blocky \\
\hline TR15 & A & 10 & 10 YR 2/2 & Sandy Loam & 2 & Weak Subangular Blocky \\
\hline TR15 & Bw & 45 & 10 YR 4/6 & Sandy Loam & 12 & Weak Subangular Blocky \\
\hline TR16 & A & 10 & $7.5 Y R 3 / 3$ & Sandy Loam & 5 & Weak Subangular Blocky \\
\hline TR16 & Bw & 47.5 & 10 YR 4/6 & Sandy Loam & 12 & Weak Subangular Blocky \\
\hline TR17 & A & 8 & $7.5 Y R 3 / 2$ & Sandy Loam & 5 & Weak Subangular Blocky \\
\hline TR17 & Bw & 40 & 10 YR 6/4 & Sandy Loam & 12 & Weak Subangular Blocky \\
\hline TR18 & A & 5 & $2.5 Y R 3 / 2$ & Sandy Loam & 5 & Weak Subangular Blocky \\
\hline TR18 & Bw & 40 & 10 YR 5/4 & Sandy Loam & 12 & Weak Subangular Blocky \\
\hline
\end{tabular}




\section{Appendix G: Site and Soil Pit Images from Sites Sampled During Phase II Sampling (2010)}

This appendix contains two photographs for each site sampled during Phase II Sampling in 2010 (Appendix E: Site Observations for Phase II (2010) Sites; Appendix F: Description of Phase II Soil Samples (2010)).

The upper photograph for each site shows the soil pit from which the samples were collected. The red line drawn on each of the upper photographs separates the A horizon and B horizon. Horizons are labeled on each photograph. The B horizon soils are further classified as Bw (younger) or Bt (older and more well developed) horizons (Birkeland, 1999). The samples taken at each pit are further described in Appendix F: Description of Phase II Soil Samples (2010).

The lower photograph for each site illustrates the surrounding conditions at the

site, particularly vegetation. Site descriptions are further described in Appendix E: Site Observations for Phase II (2010) Sites. 
SITE TR-1:
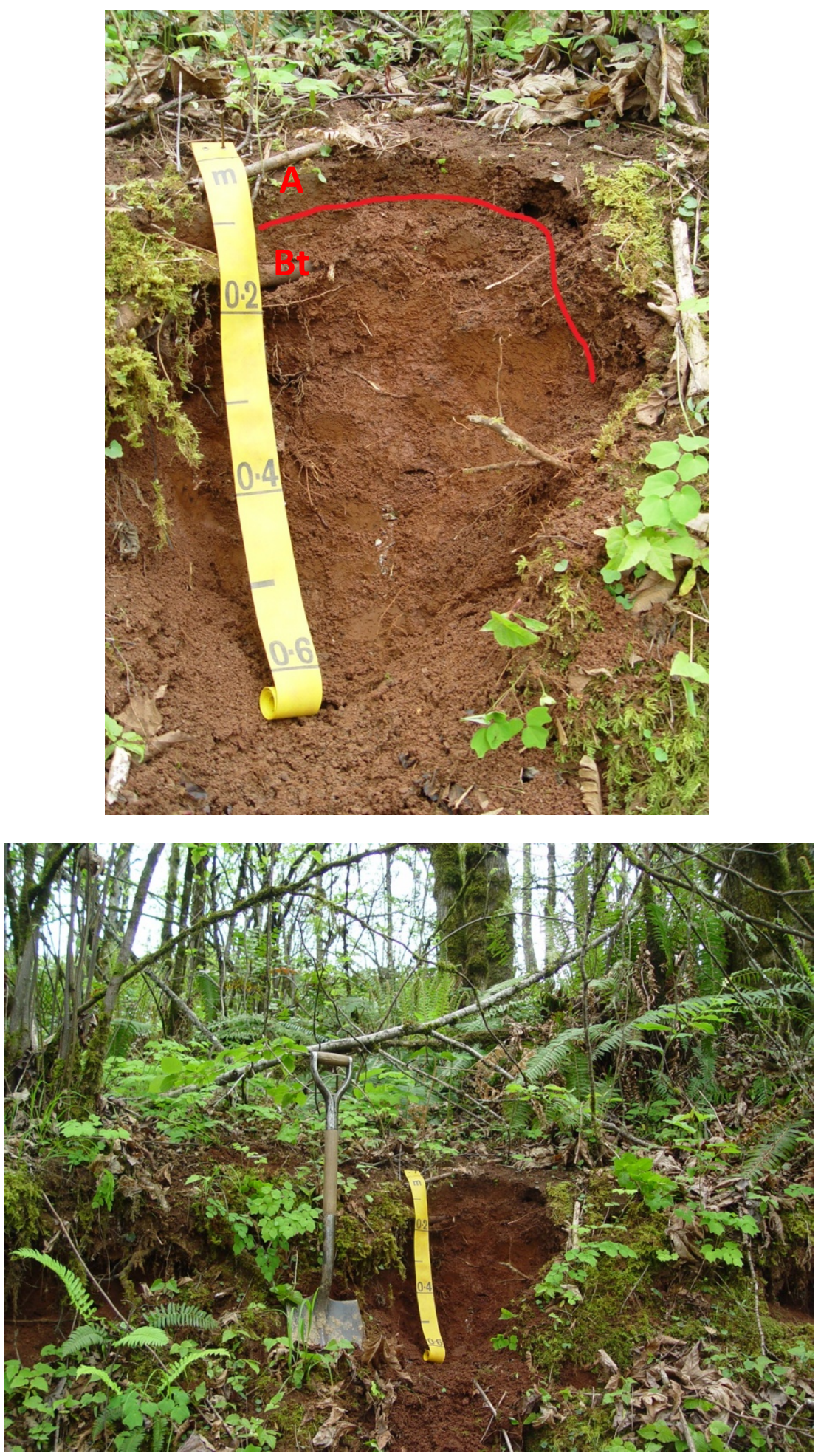
SITE TR-2:
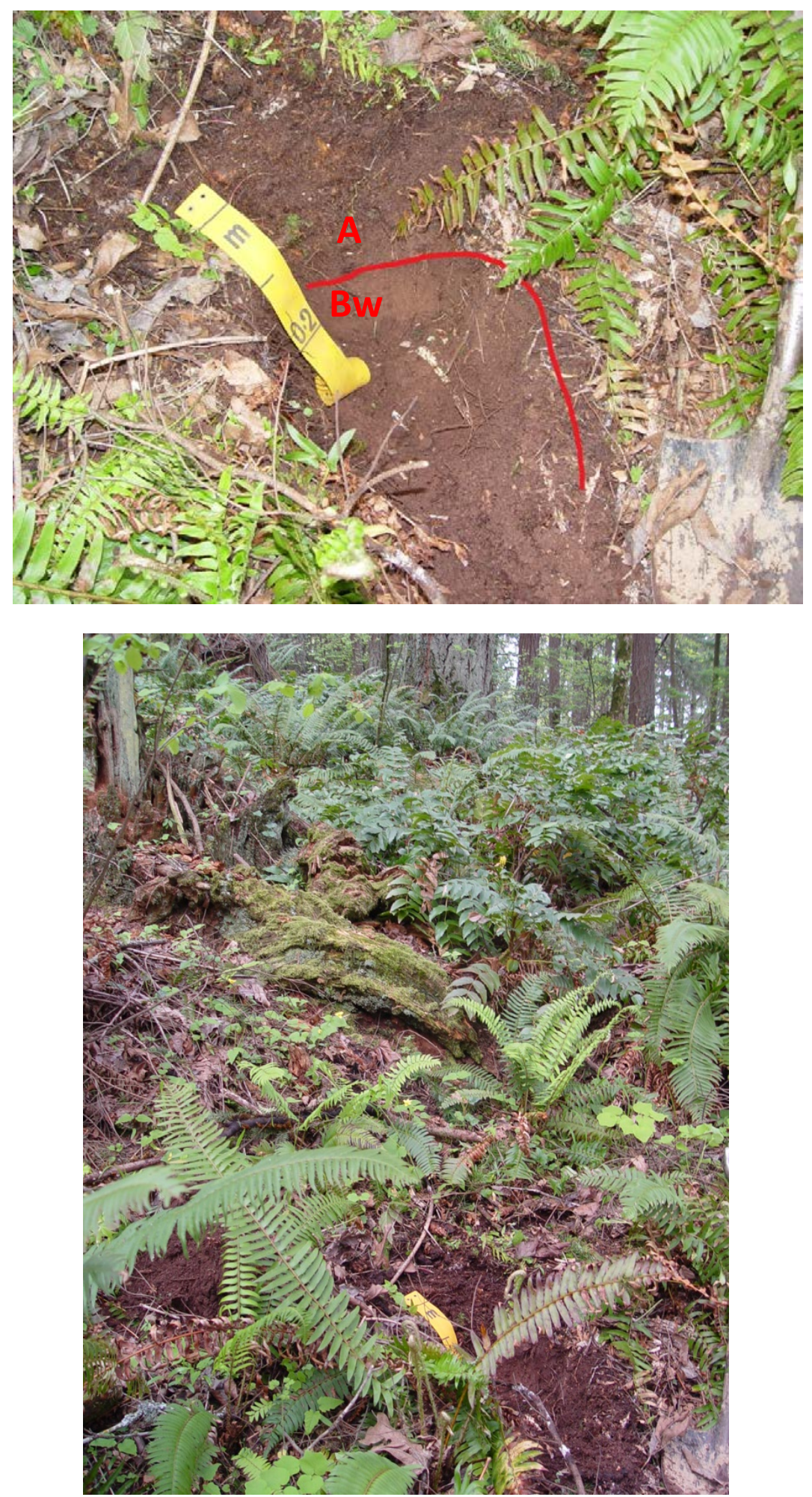
SITE TR-3:
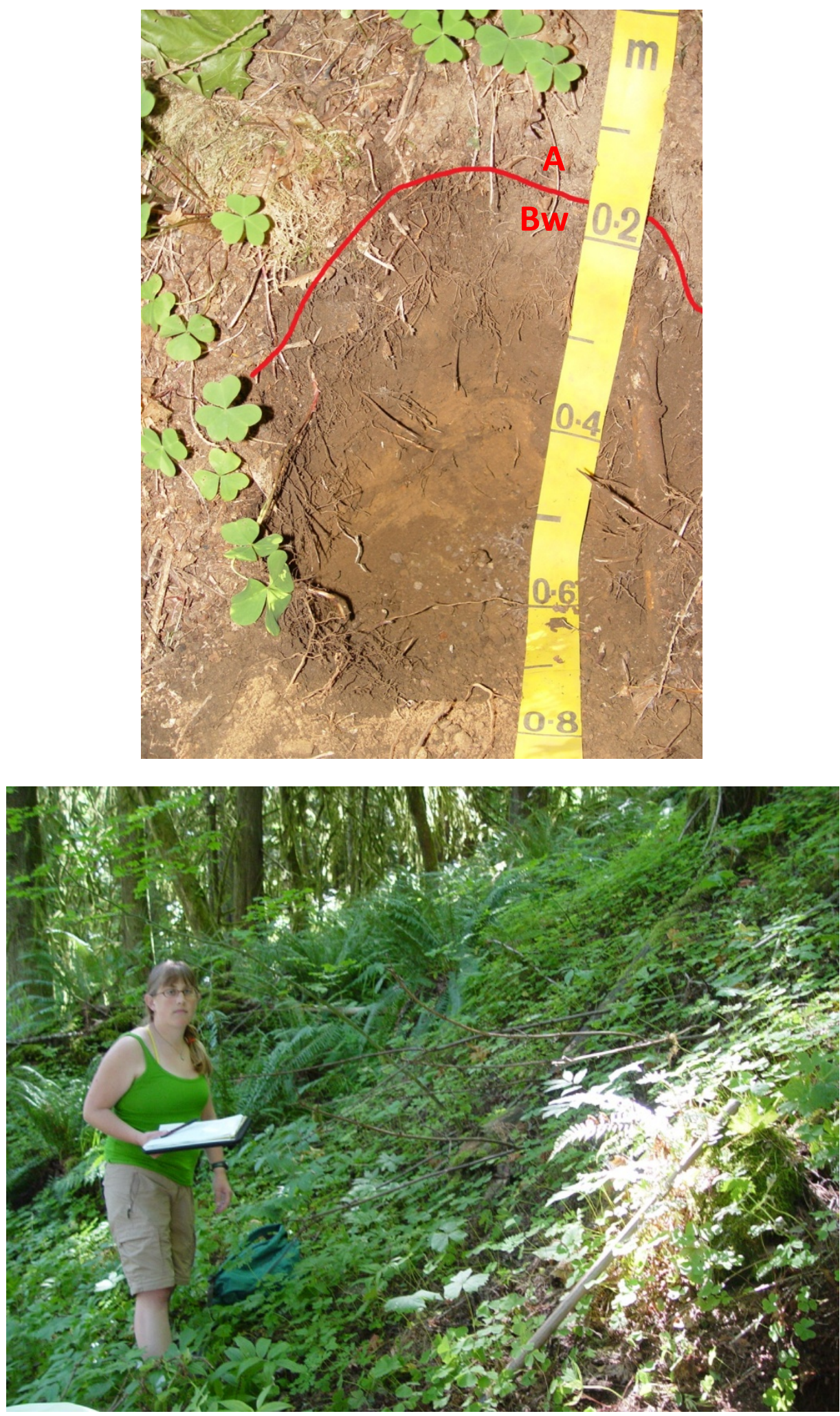
SITE TR-4:
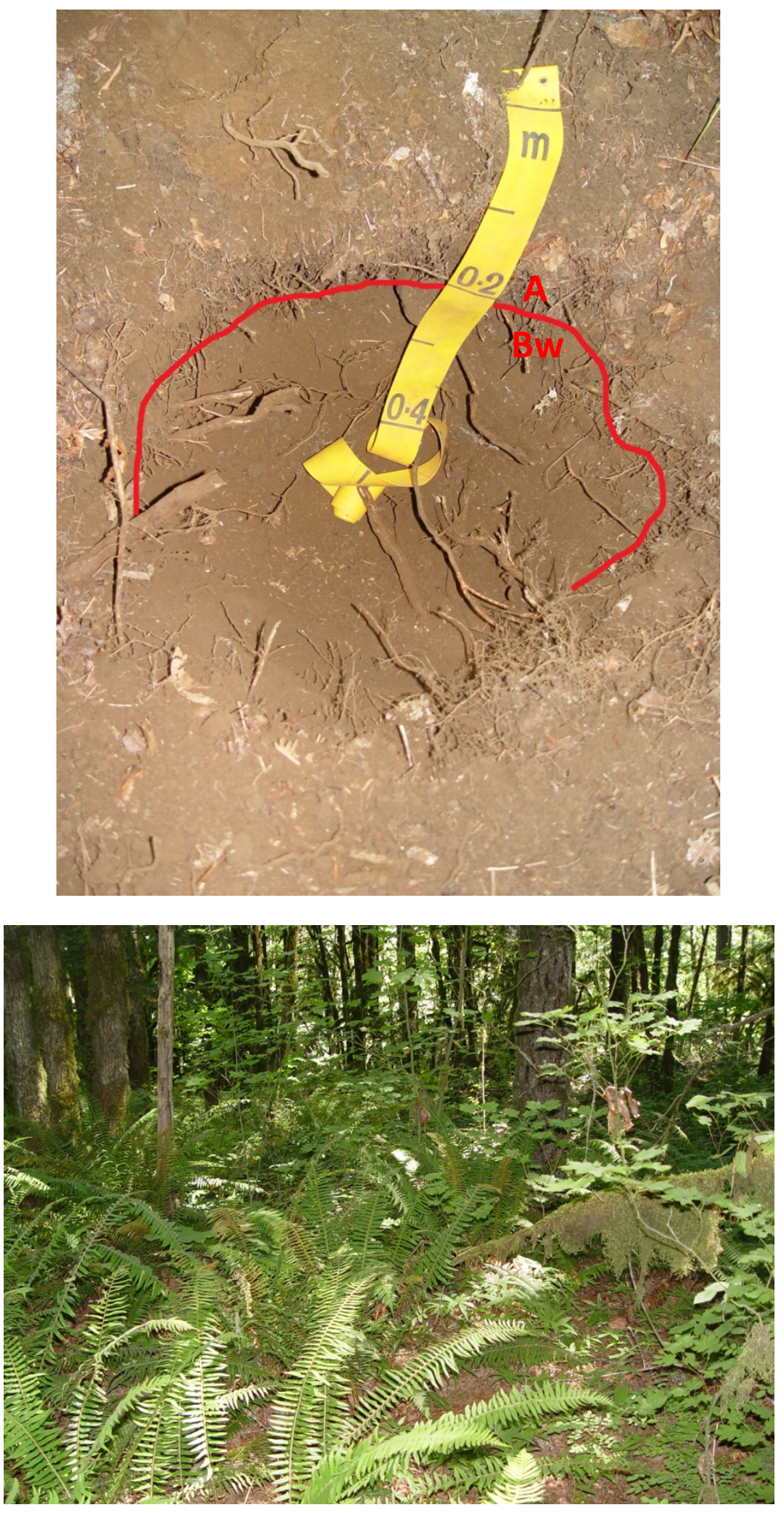
SITE TR-5:
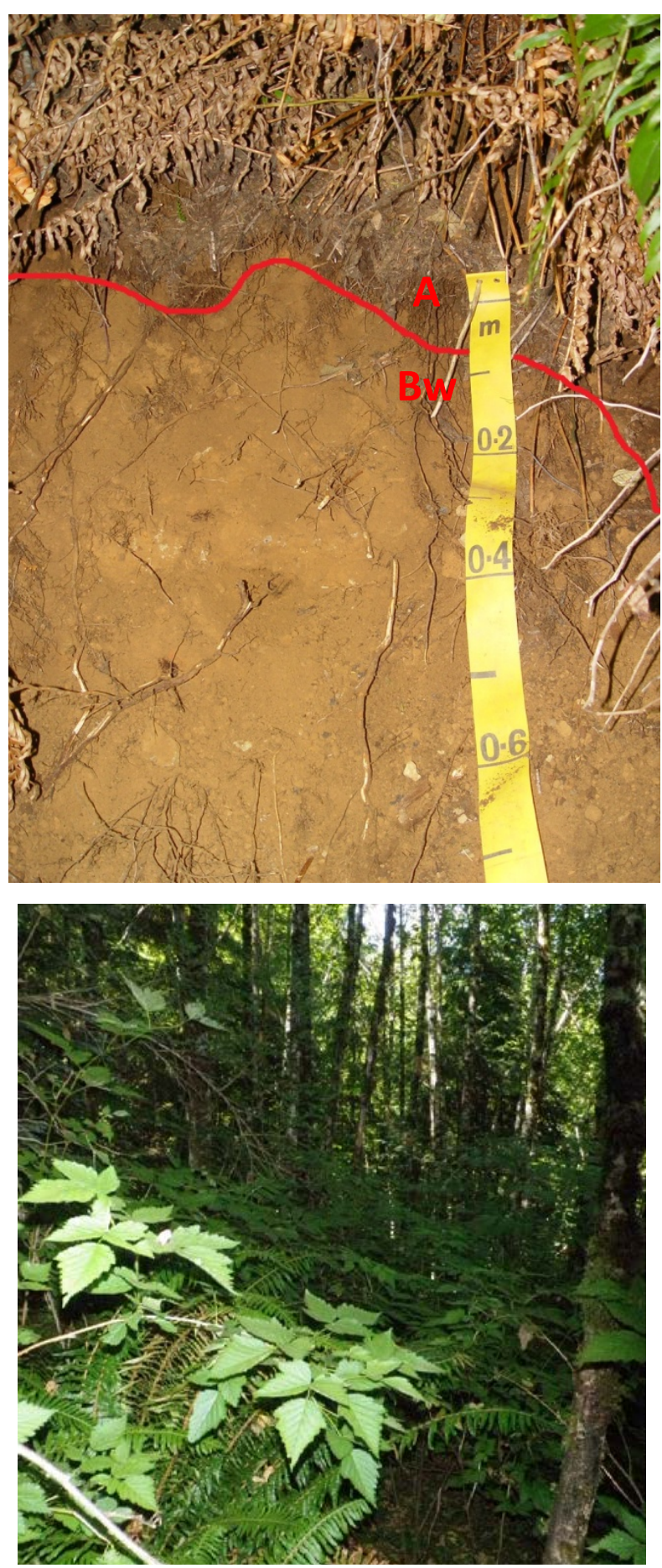

SITE TR-6: 

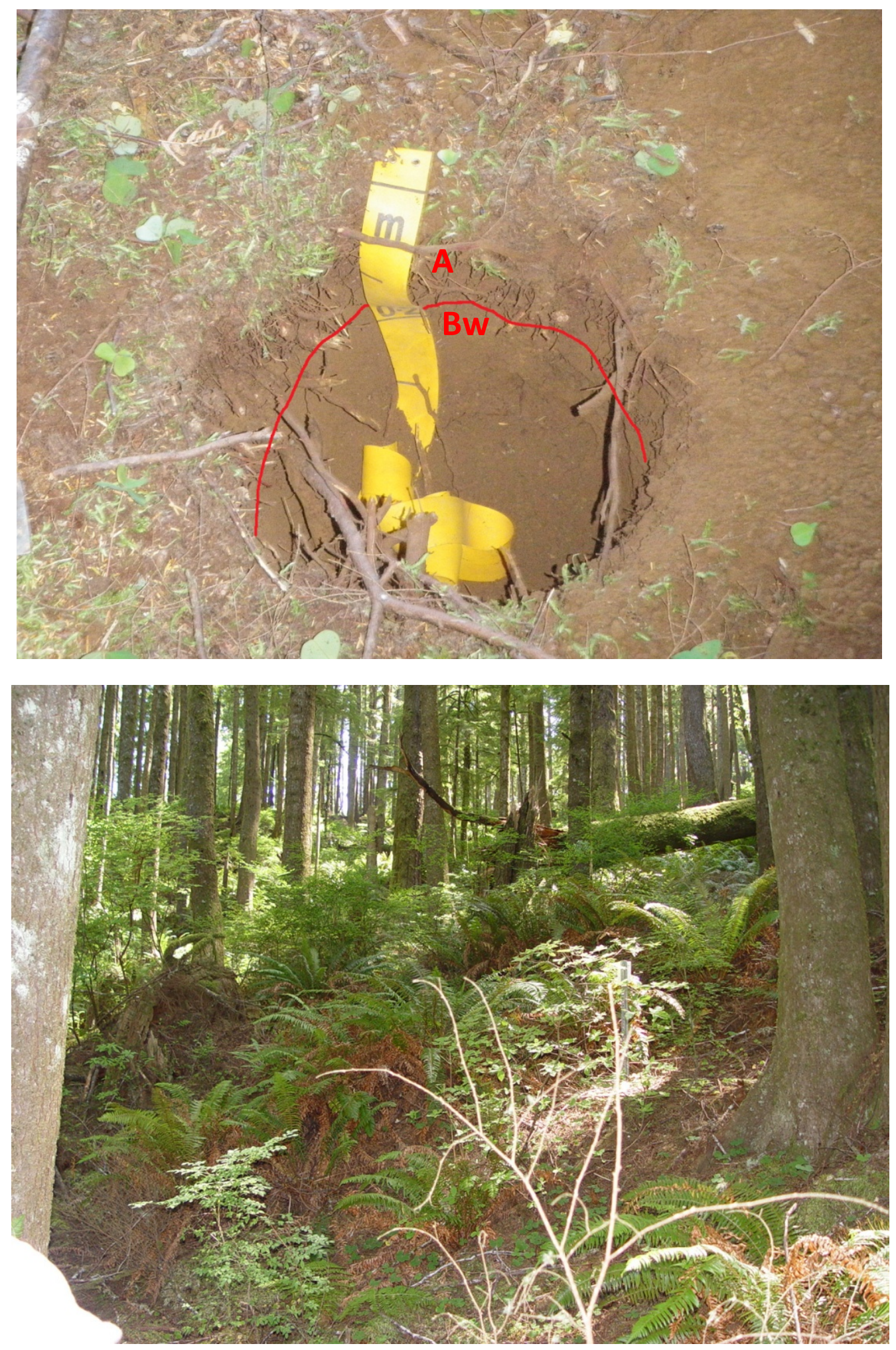

SITE TR-7: 

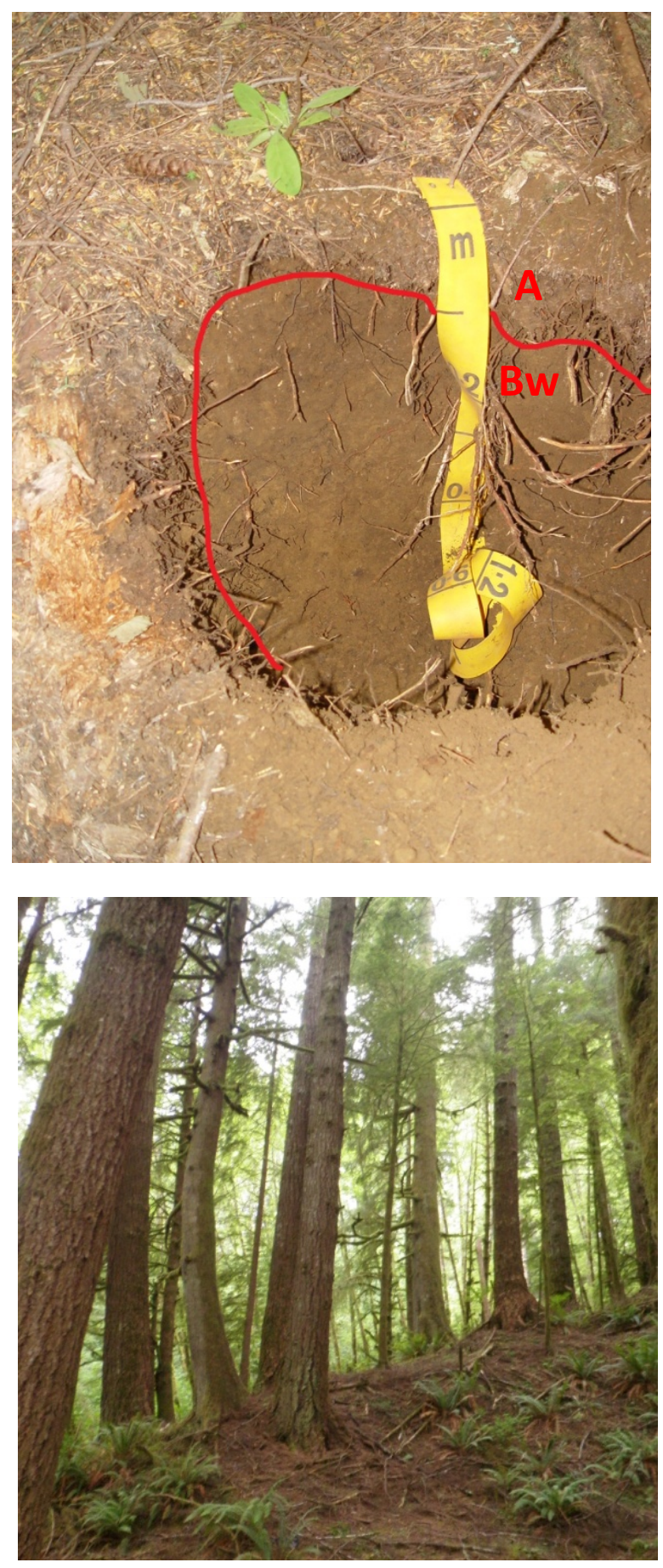

SITE TR-8: 

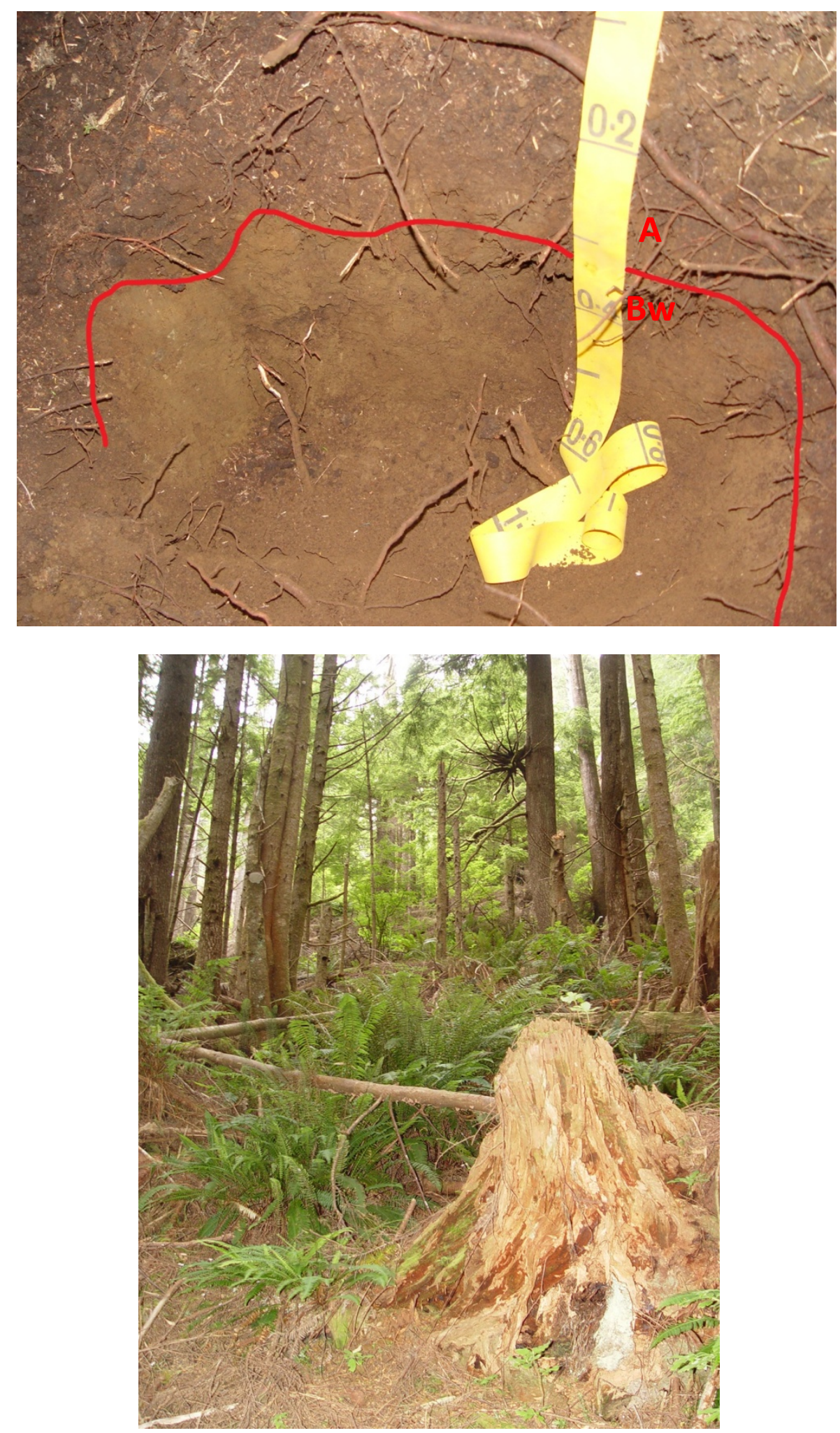

SITE TR-9: 

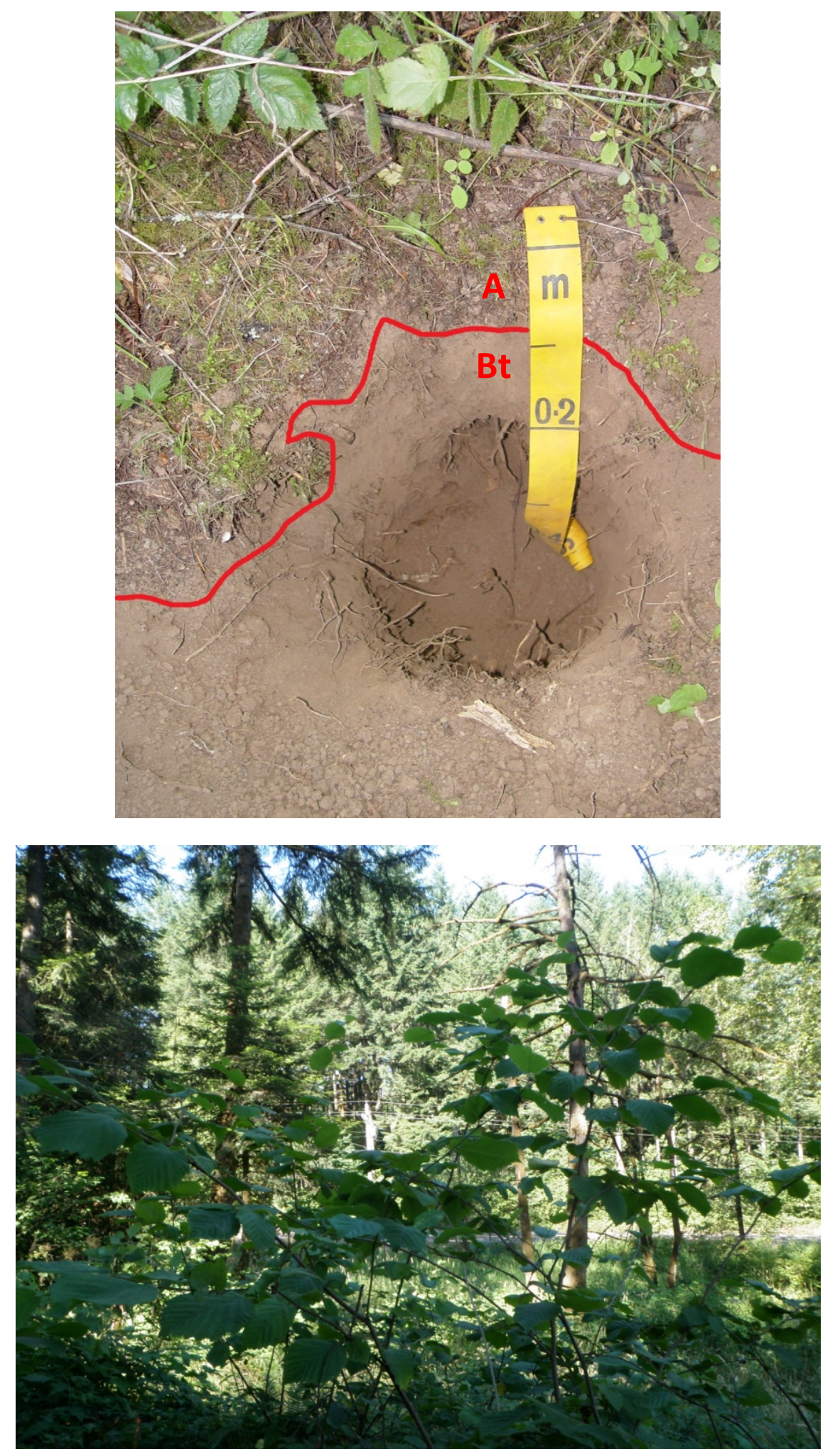

SITE TR-10: 

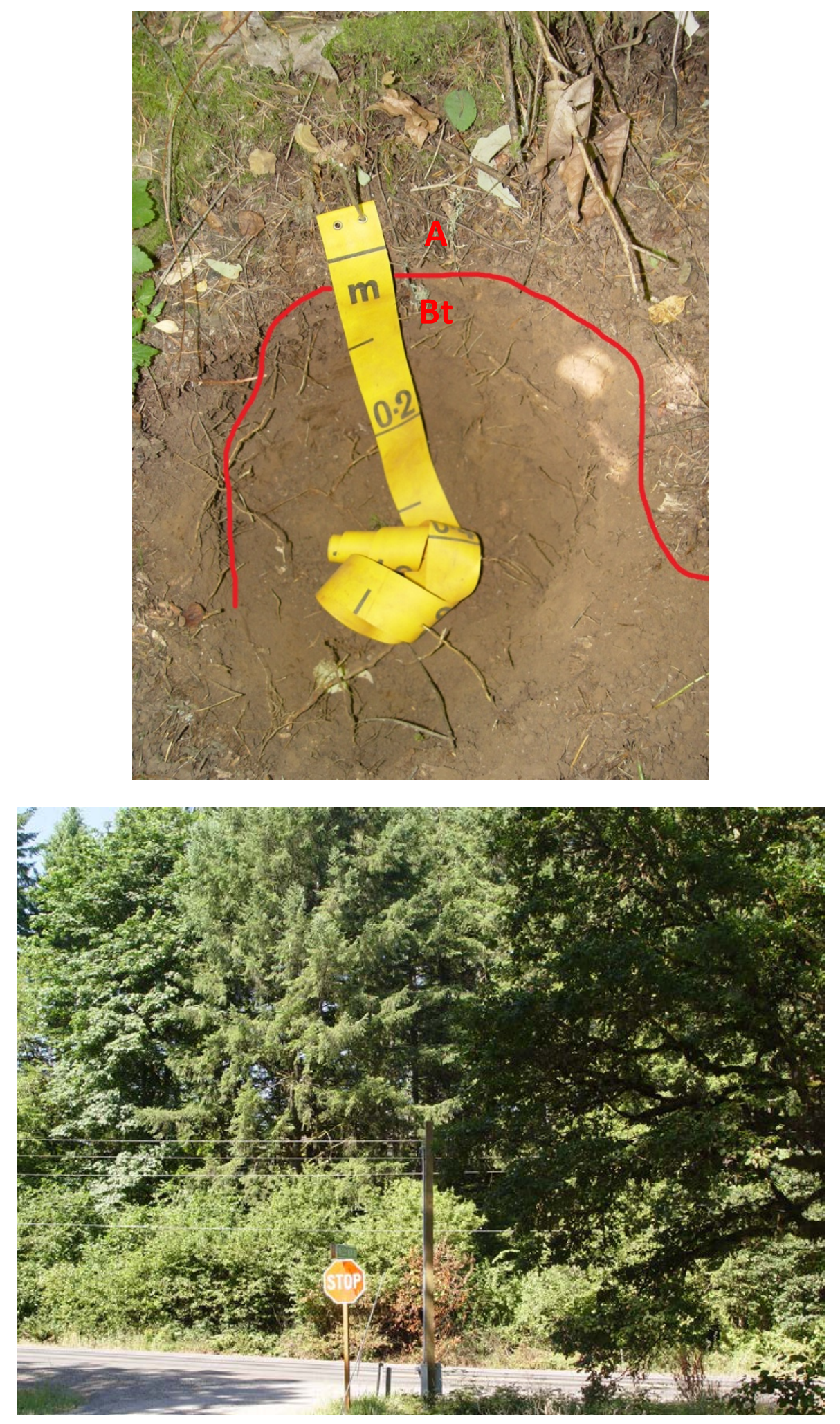

SITE TR-11: 

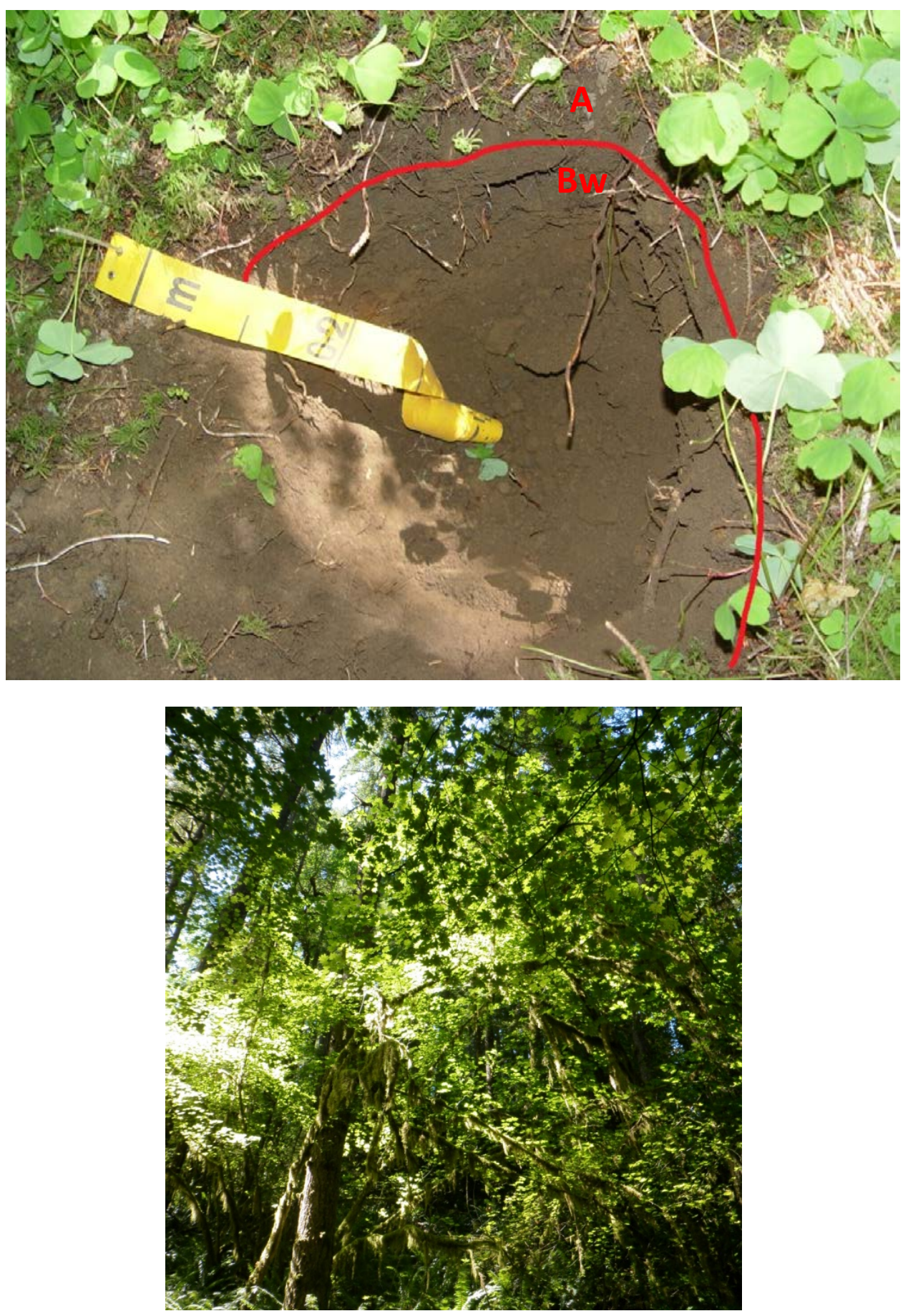

SITE TR-12: 

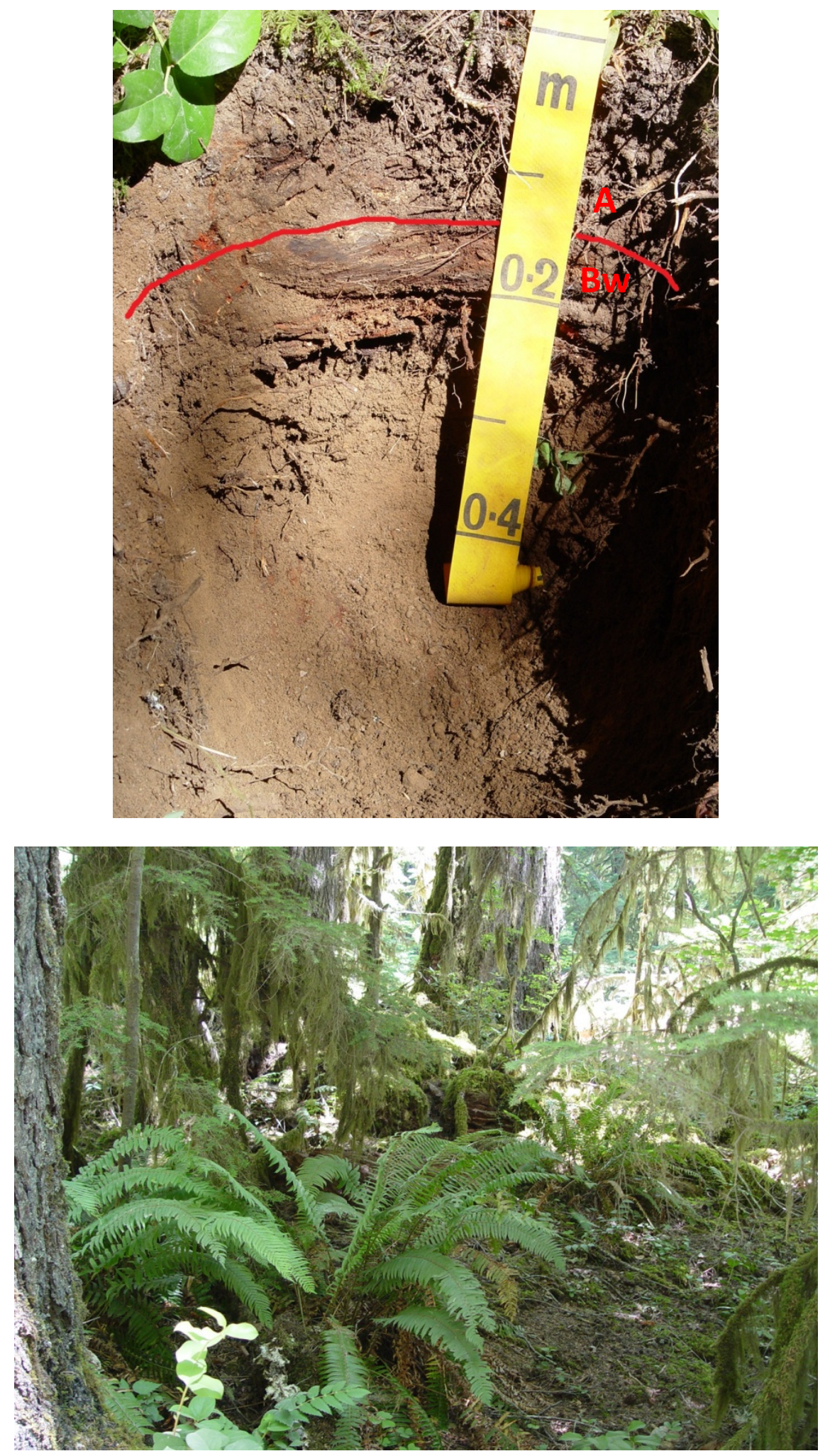

SITE TR-13: 

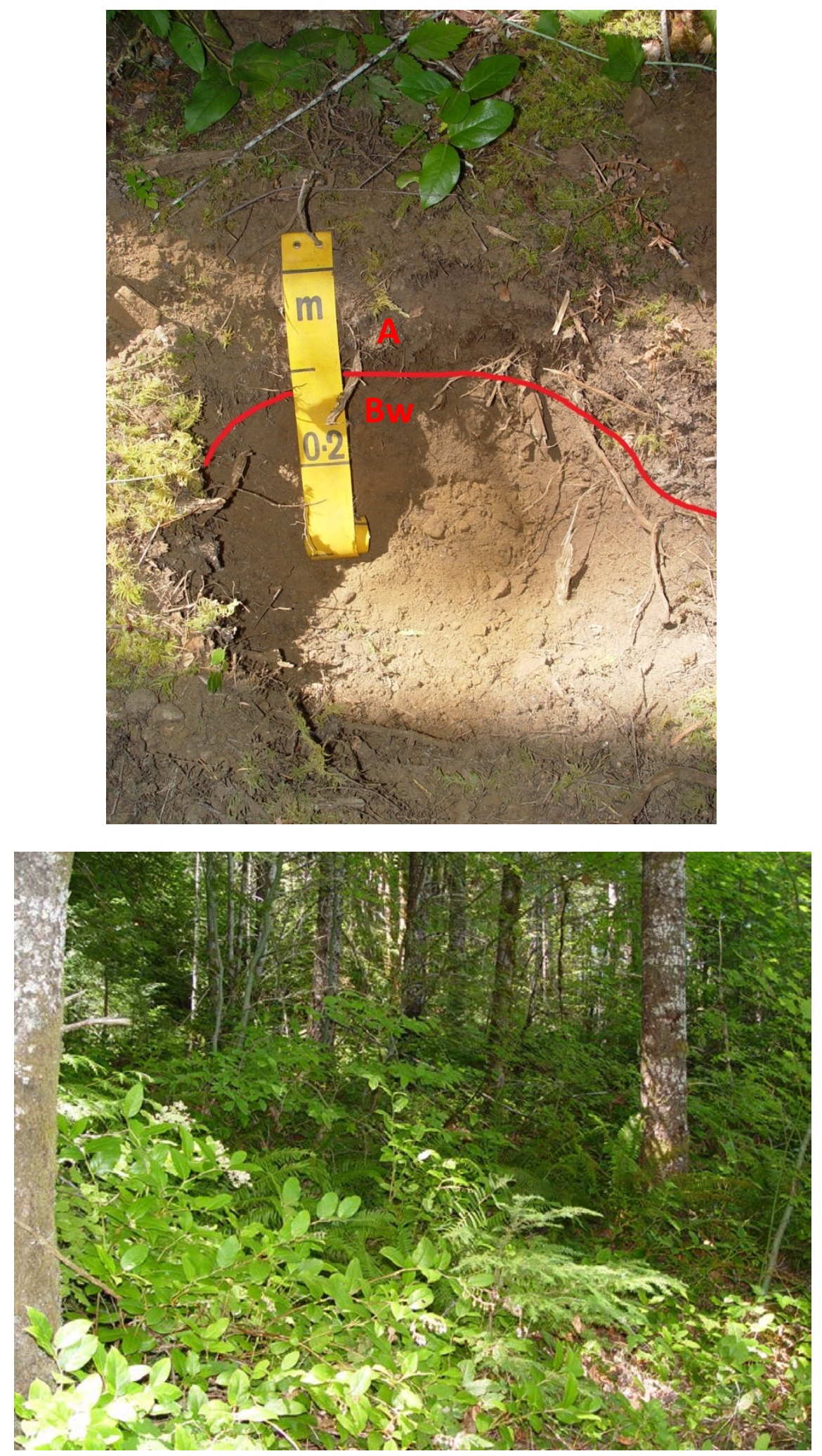

SITE TR-14: 

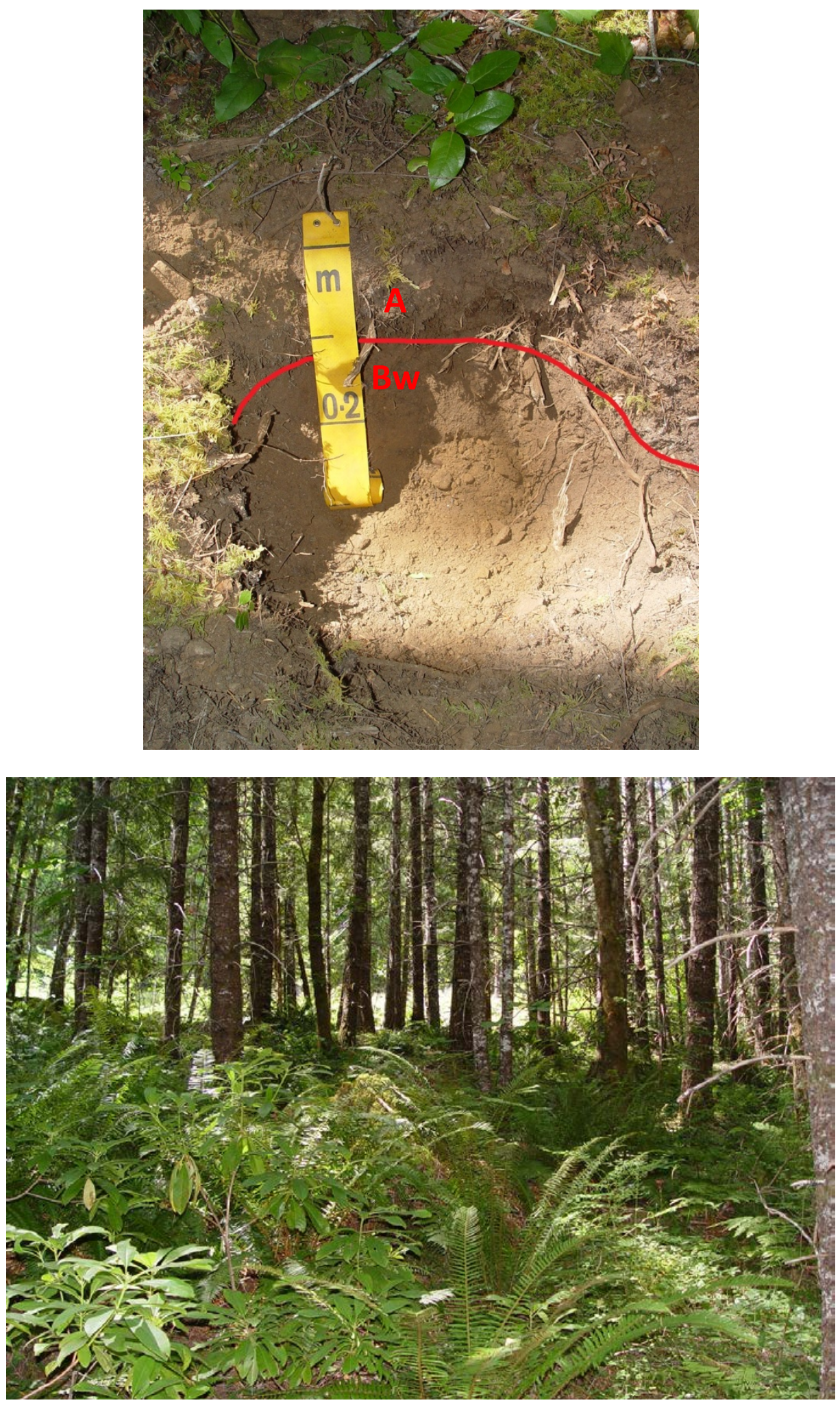

SITE TR-15: 

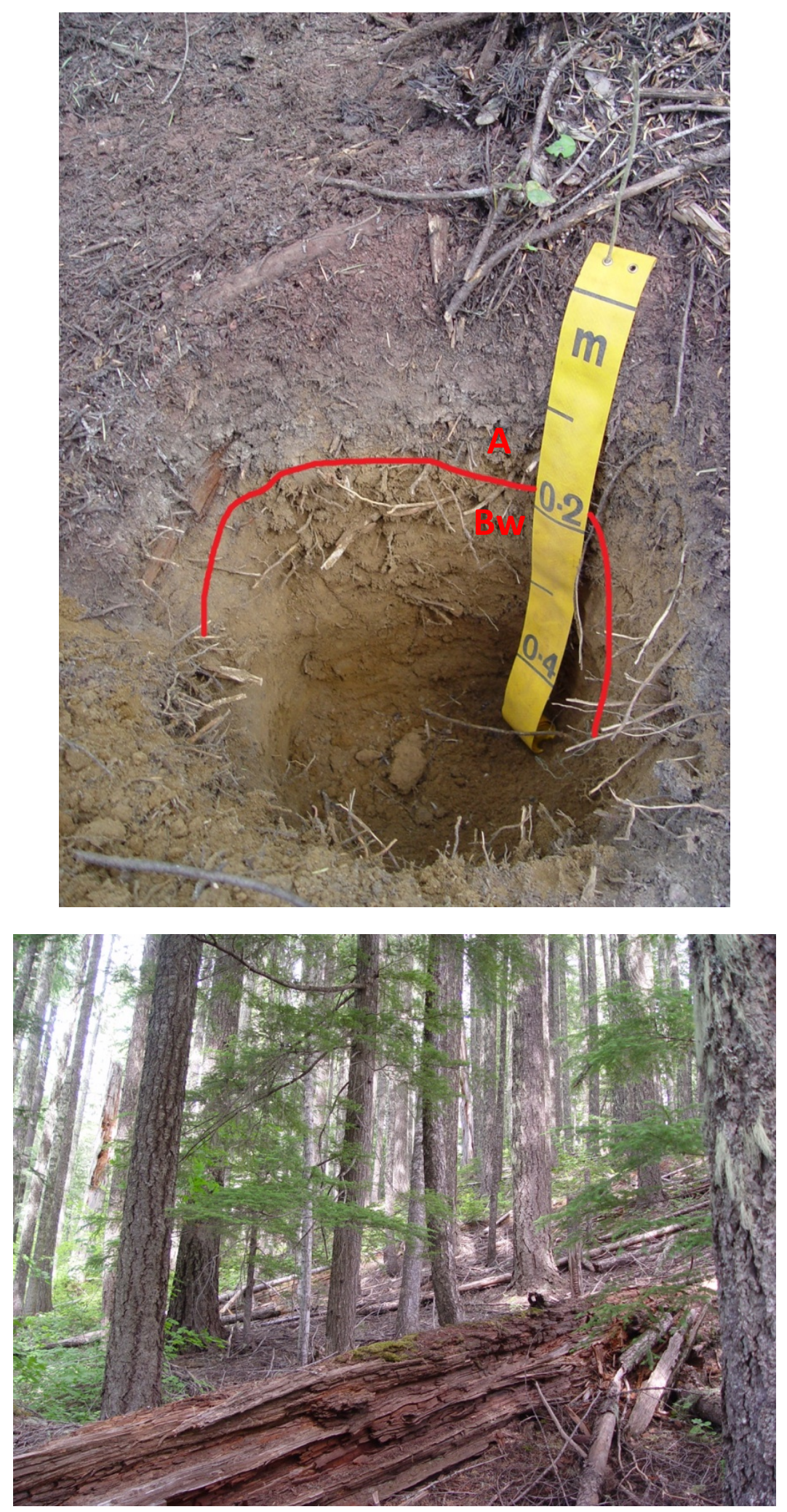

SITE TR-16: 

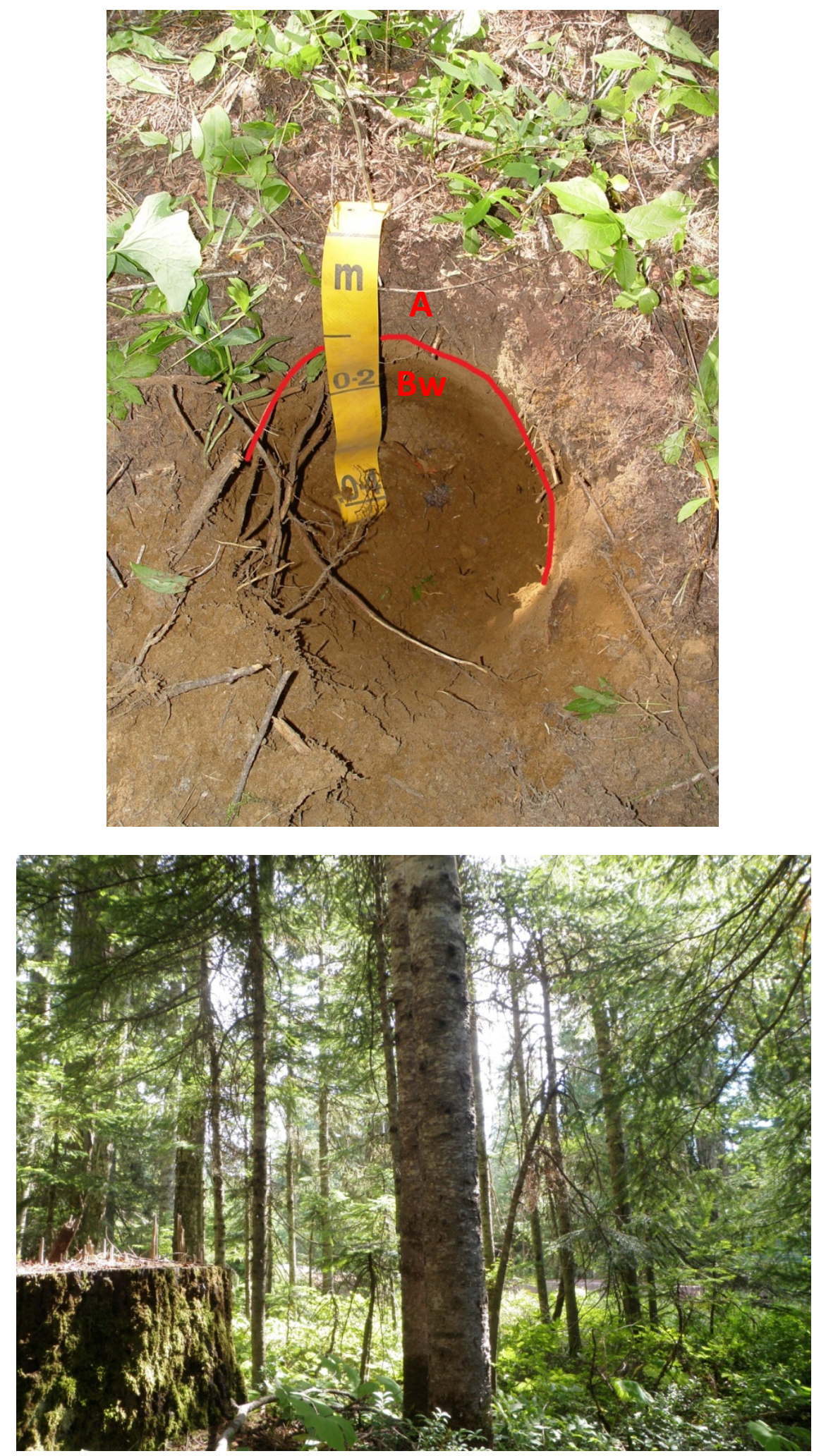

SITE TR-17: 

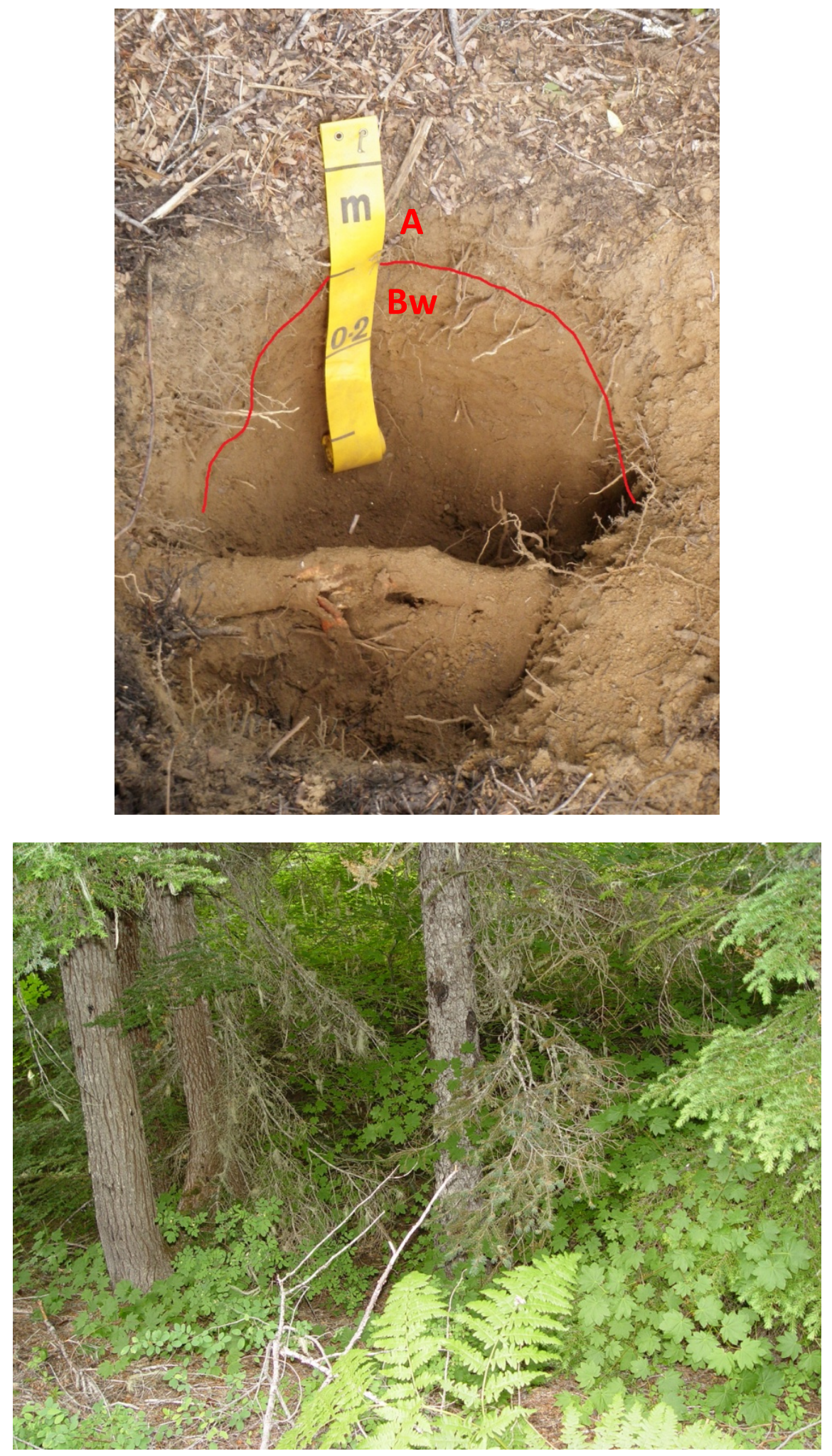

SITE TR-18: 

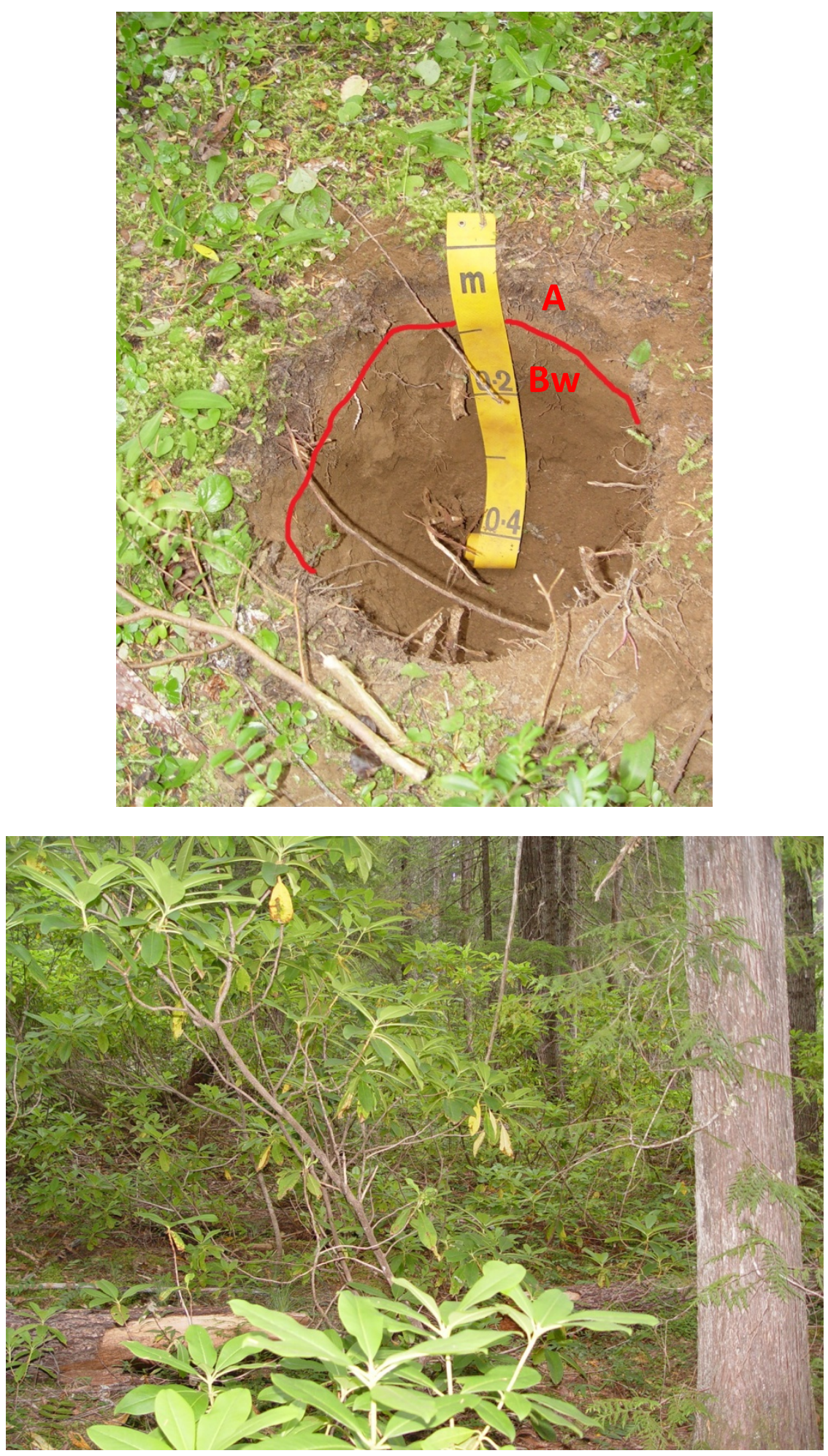
Appendix H: Example page from APEX Laboratory's Quality Control Sample Results Report

$\begin{array}{ll}\text { Apex Labs } & 12232 \text { S.W. Garden Place } \\ \text { Tigard, OR 97223 } \\ 503-718-2323 \text { Phone } \\ 503-718-0333 \text { Fax }\end{array}$

\begin{tabular}{|ll}
\hline GeoEngineers -Seattle & Project: \\
600 Stewart St. Suite 1700 & Project Number: $2787-050-000$ \\
Seattle, WA 98101 & Project Manager: Neil Morton \\
\hline
\end{tabular}

Reported:

Seattle, WA 98101

Project Manager: Neil Morton

05/01/10 10:42

QUALITY CONTROL (QC) SAMPLE RESULTS

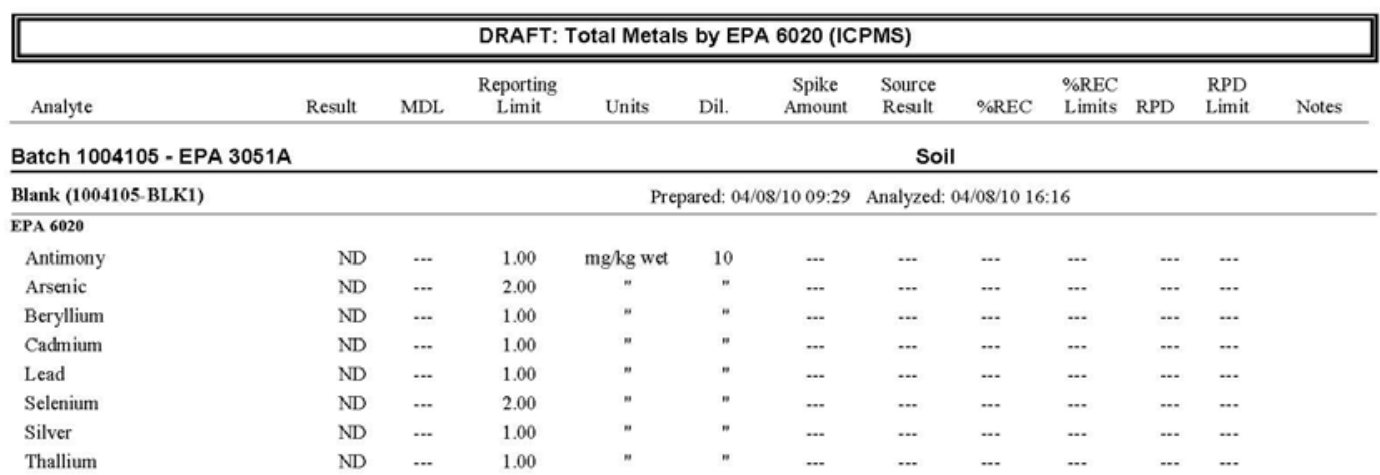

\begin{tabular}{|c|c|c|c|c|c|c|c|c|c|c|c|}
\hline \multicolumn{12}{|l|}{ EPA 6020} \\
\hline Antimony & 25.8 & $\cdots$ & 1.00 & $\mathrm{mg} / \mathrm{kg}$ wet & 10 & 25.0 & $\ldots$ & 103 & $80-120 \%$ & $\ldots$ & $\cdots$ \\
\hline Arsenic & 48.9 & $\cdots$ & 2.00 & " & $"$ & 50.0 & $\cdots$ & 98 & $"$ & $\ldots$ & $\ldots$ \\
\hline Beryllium & 24.7 & $\ldots$ & 1.00 & $"$ & $"$ & 25.0 & $\ldots$ & 99 & $"$ & $\ldots$ & ... \\
\hline Cadmium & 50.1 & $\ldots$ & 1.00 & " & $"$ & 50.0 & $\ldots$ & 100 & $"$ & $\ldots$ & $\ldots$ \\
\hline Lead & 46.6 & $\ldots$ & 1.00 & " & $"$ & " & $\ldots$ & 93 & $"$ & ... & $\ldots$ \\
\hline Selenium & 23.9 & $\ldots$ & 2.00 & $"$ & $"$ & 25.0 & $\ldots$ & 96 & $"$ & ... & $\ldots$ \\
\hline Silver & 24.6 & $\ldots$ & 1.00 & $"$ & $"$ & $"$ & $\ldots$ & 99 & $"$ & $\ldots$ & $\ldots$ \\
\hline Thallium & 23.8 & $\ldots$ & 1.00 & $"$ & $"$ & $"$ & $\ldots$ & 95 & $"$ & $\ldots$ & $\ldots$ \\
\hline
\end{tabular}

Duplicate (1004105-DUP1)

Prepared: 04/08/10 09:29 Analyzed: 04/08/10 16:54

QC Source Sample: P07B1a (A 10D053-05)

EPA 6020

\begin{tabular}{|c|c|c|c|c|c|c|c|c|c|c|c|}
\hline Antimony & ND & $\cdots$ & 1.11 & $\mathrm{mg} / \mathrm{kg}$ dry & 10 & $\cdots$ & ND & $\cdots$ & $\cdots$ & $\cdots$ & $40 \%$ \\
\hline Arsenic & 2.69 & $\ldots$ & 2.22 & " & $"$ & $\ldots$ & 2.81 & $\ldots$ & $\ldots$ & 5 & $40 \%$ \\
\hline Beryllium & $\mathrm{ND}$ & $\cdots$ & 1.11 & $"$ & $"$ & $\cdots$ & $\mathrm{ND}$ & $\cdots$ & $\cdots$ & $\cdots$ & $40 \%$ \\
\hline Cadmium & $\mathrm{ND}$ & $\ldots$ & 1.11 & $"$ & $"$ & $\ldots$ & ND & $\ldots$ & $\ldots$ & $\ldots$ & $40 \%$ \\
\hline Lead & 16.2 & $\cdots$ & 1.11 & $"$ & $"$ & $\ldots$ & 15.9 & ... & ... & 2 & $40 \%$ \\
\hline Selenium & $\mathrm{ND}$ & $\cdots$ & 2.22 & $"$ & $"$ & $\ldots$ & $\mathrm{ND}$ & $\ldots$ & $\ldots$ & $\ldots$ & $40 \%$ \\
\hline Silver & $\mathrm{ND}$ & $\cdots$ & 1.11 & $"$ & $"$ & $\cdots$ & ND & $\cdots$ & $\cdots$ & $\cdots$ & $40 \%$ \\
\hline Thallium & ND & $\cdots$ & 1.11 & $"$ & $"$ & $\cdots$ & ND & $\cdots$ & $\cdots$ & $\cdots$ & $40 \%$ \\
\hline
\end{tabular}

Matrix Spike (1004105-MS1)

Prepared: 04/08/10 09:29 Analyzed: 04/08/10 16:57

QC Source Sample: P07B1a (A10D053-05)

DRAFT REPORT

The results provided in this report are PRELIMINARY and are subject to change based on subsequent andysis. $Q C$ validation or final data review. Please use these resuls. with the understanding that they may have not been finalized by the laboratory 


\section{Appendix I: Descriptions of Lithology by Lithologic Group}

This appendix contains an explanation of rock units found within the study area of this project. descriptions of all underlying bedrock geology from above which soil was sampled for this project. Descriptions are provided primarily verbatim from Walker and MacLeod's (1991) Geologic Map of Oregon. The units are not listed in order of youngest to oldest, but are provided grouped by the lithologic groups discussed in Chapter 4.4: GROUPINGS FOR STATISTIC ANALYSIS.

\section{Appendix I.1: Quaternary/ Tertiary Sediments and Sedimentary Rocks}

\section{Qal - Alluvial deposits (Holocene)}

Sand, gravel, and silt forming flood plains and filling channels of present streams. In places includes talus and slope wash. Locally includes unconsolidated sediment marginal to playas, soils containing abundant organic material, and thin peat beds.

\section{Qs - Lacustrine and fluvial sedimentary rocks (Pleistocene)}

Unconsolidated to semiconsolidated lacustrine clay, silt, sand, and gravel; in places includes mudflow, fluvial, and eolian deposits and discontinuous layers of peat. In places contains mollusks or vertebrate fossils indicating Pleistocene age; mostly deposits of late Pleistocene age, but locally includes some deposits of early Holocene age. Includes Touchet Beds of Flint (1938) and deposits of valley terraces of Newcomb (1965). Author's Note: This unit includes Missoula Flood sediments. 


\section{Qg - Glacial deposits (Pleistocene)}

Unsorted boulder gravel, sand, and rock flour in ground, terminal, and lateral moraines.

\section{QTs - Sedimentary rocks (Pleistocene and Pliocene)}

Semiconsolidated lacustrine and fluvial ashy and palagonitic sedimentary rocks, mostly tuffaceous sandstone and siltstone; locally contains abundant palagonitized basaltic debris and some pebble conglomerate. Includes alluvial gravel and mudflow deposits of Walters Hill and Springwater Formations (Trimble, 1963). In places, grades laterally through palagonite tuff and breccia into basalt flows.

\section{Ts - Tuffaceous sedimentary rocks and tuff (Pliocene and Miocene)}

Semiconsolidated to well-consolidated mostly fluviatile tuffaceous sandstone, siltstone, mudstone, concretionary claystone, conglomerate pumicite, air-fall and waterdeposited vitric ash, palagonitic tuff and tuff breccia. Palagonitic tuff and breccia grade laterally into altered and unaltered basalt flows of unit Tob. Also includes thin, welded and nonwelded ash-flow tuffs. Includes the Dalles Formation of Newcomb $(1966,1969)$; the Madras (or Deschutes) Formation, and the Sandy River Mudstone and the Troutdale Formation of Trimble (1963) and the lower Pliocene Helvetia Formation of Schlicker and Deacon (1967). 
Qgs - Glaciofluvial, lacustrine, and pediment sedimentary deposits (Pleistocene)

Unconsolidated, poorly sorted silt, sand, and gravel. Mostly in northern Morrow and Umatilla Counties where unit represents deposits of swollen late Pleistocene Columbia River (Hogenson, 1964)

Appendix I.2: Marine Sediments and Sedimentary Rocks

Tco - Cowlitz Formation (upper and middle Eocene)

Micaceous, arkosic to basaltic marine sandstone, siltstone, and mudstone.

Foraminiferal assemblages are referred to the upper Narizian Stage of Mallory (1959) in Newton and Van Atta (1976). 


\section{Tms - Marine sedimentary rocks (middle and lower Miocene)}

Fine- to medium -grained marine siltstone and sandstone that commonly contains tuff beds. Includes the Astoria Formation, which is mostly micaceous and carbonaceous sandstone, and the middle Miocene Gnat Creek Formation of Niem and Niem (1985), which overlies Frenchmen Springs Member of the Wanapum Basalt of east of Astoria. The Astoria Formation locally contains calcareous concretions and sulfide nodules; foraminifera in formation are assigned to the Saucesian and Relizian Stange (Kleinpell, 1938; Rau, 1981) and molluscan fossils to the Newportian Stage of Addicott $(1976,1981)$. Also includes Nye Mudstone, which is massive to poorly bedded siltstone and mudstone; foraminiferal assemblages assigned to the Saucesian Stage (Kleinpell, 1938; Rau, 1981) and molluscan fauna to Pillarian (?) Stage (Armentrout, 1981).

\section{Tmst - Marine sedimentary and tuffaceous rocks (middle Miocene to upper Eocene)}

Tuffaceous and arkosic sandstone, locally fossiliferous, tuffaceous siltstone, tuff, glauconitic sandstone, minor conglomerate layers and lenses, and a few thin coal beds. Includes Scappoose Formation (Trimble, 1963; Wells et al., 1983), mudstone of Oswald West (Niem and Van Atta ,1973; Wells et al., 1983), Pittsburg Bluff Formation (Wells et al., 1983), and Smuggler Cove and Northrup Creek formations (informal names) of Niem and Niem (1985). 


\section{Tsd - Sedimentary rocks (Oligocene and upper Eocene)}

Marine shale siltstone, sandstone, and conglomerate, in places partly composed of tuffaceous and basaltic debris; interbeds of arkosic, glauconitic and quartzose sandstone. Foraminifera are referable to the Refugian and Zemorrian stages (see marine sedimentary rocks - units Toes and Toem - of Wells et al., 1983). Includes Bastendorff Formation of Baldwin (1974).

\section{Tss - Tuffaceous siltstone and sandstone (upper and middle Eocene)}

Thick- to thin- bedded marine tuffaceous mudstone, siltstone, and sandstone; fine to coarse grained. Contains calcareous concretions and, in places, is carbonaceous and micaceous. Includes the Nestucca Formation, which contains a foraminiferal assemblage assigned to the upper Narizian and lowermost Refugian Stages (Snavely et al., 1969; McKeel, 1980); the Spencer Formation, which contains Narizian Stage foraminifera; the Keasy Formation, which contains upper Narizian and lower Refugian Stage foraminifera (McDougall, 1975, 1980); the Coaledo and Bateman formations of Baldwin (1974); upper Eocene sandstone of Bela (1981); and the Sager Creek Formation (informal name) of Niem and Niem (1985). 


\section{Tt - Tyee Formation (middle Eocene)}

Very thick sequence of rhymically bedded, medium- to fine-grained micaceous, feldspathic, lithic, or arkosic marine sandstone and micaceous carbonaceous siltstone; contains minor interbeds of dacite tuff in upper part. Foraminiferal fauna are referred to the Ulatisian Stage (Snavely et al., 1964). Groove and flute casts indicate deposition by north-flowing turbidity currents (Snavely et al., 1964), but probable provenance of unit is southwest Idaho (Heller et al., 1985).

\section{Ty - Yamhill Formation and related rocks (upper and middle Eocene)}

Massive to thin-bedded concretionary marine siltstone and thin interbeds of arkosic, glauconitic, and basaltic sandstone; locally contains interlayered basalt lava flows and lapilli tuff. Foraminiferal assemblages in siltstone referred to the Ulatisian and lower Narizian Stages (Snavely et al., 1969; McKeel, 1980) Includes the Elkton Formation of Baldwin (1974; also see Beaulieu and Hughes, 1975), which consists of thin-bedded siltstone and minor sandstone interbeds. 


\section{Appendix 1.3: Mafic Intrusions}

\section{Ti - Mafic intrusions (Oligocene)}

Sheets, sills, and dikes of massive granophyric ferrogabbro; some bodies strongly differentiated and include pegmatic gabbro, ferrogranophyre, and granofyre (MacLeod, 1981). Plagioclase and amphibole from unit have yielded $\mathrm{K}-\mathrm{Ar}$ ages of about $30 \mathrm{Ma}$ (Snavely et al., 1976a).

\section{Appendix I.4: Coast Range Basalts}

\section{Tsr - Siletz River Volcanics and related rocks (middle and lower Eocene and Paleocene)}

Aphanitic to porphyritic, vesicular pillow flows, tuff-breccias, massive lava flows and sills of tholeiitic and alkalic basalt. Upper part of sequence contains numerous interbeds of basaltic siltstone and sandstone, basaltic tuff, and locally derived basalt conglomerate. Rocks of unit pervasively zeolitized and veined with calcite. Most of these rocks are of marine origin and have been interpreted as oceanic crust and seamounts (Snavely et al., 1968). Foraminiferal assemblages referred to the Ulatisian and Penutian Stages (Snavely et al., 1969); K-Ar ages range from 50.7+/-3.1 to 58.1+/-1.5 Ma (Duncan, 1982); includes the lower part of the Roseburg Formation of Baldwin (1974), which has yielded $\mathrm{K}-\mathrm{Ar}$ ages as old as $62 \mathrm{Ma}$. 


\section{Ttv - Tillamook Volcanics (upper and middle Eocene)}

Subaerial basaltic flows and breccia and submarine basaltic breccia, pillow lavas, lapilli and augite-rich tuff with interbeds of basaltic sandstone, siltstone, and conglomerate. Includes some basaltic andesite and, near the top of the sequence, some dacite. Potassium-argon ages on middle and lower parts of sequence range from about 43 to 4 Ma (Magill et al., 1981): one potassium-argon age from dacite near top of sequence is about $40 \mathrm{Ma}$ (Wells et al., 1983).

\section{Appendix I.5: Columbia River Basalts}

\section{Tc - Columbia River Basalt Group and related flows (Miocene) (Cascade Range)}

Subaerial basalt and minor andesite lava flows and flow breccia; locally may include

invasive basalt flows. Flows locally grade laterally into subaqueous pillow-palagonite complexes and bedded palagonitic tuff and breccia. In places includes tuffaceous sedimentary interbeds. Joints commonly coated with nontronite and other clayey alteration products. Locally deeply weathered to lateritic soil. Occurs principally in the Cascade Range. Unit includes correlative Stayton Lavas of Thayer $(1936,1939)$. See also description of unit for eastern Oregon. Swanson et al. (1979) and Swanson et al. (1981) locally separated rocks into: (Wanapum Basalt and Grande Ronde Basalt) 


\section{Tcg - Grande Ronde Basalt (middle and lower Miocene)}

Flows of dark-gray to black, aphyric tholeiitic basalt, including both high- and low-Mg chemical types (Swanson et al., 1979). Potassium-argon ages mostly in the range of 15 to 17 Ma (Lux, 1982; Fiebelkorn et al., 1983).

\section{Tob - Olivine basalt (Pliocene and Miocene)}

Thin, commonly open-textured (diktytaxitic), subophitic to intergranular olivine basalt flows, intercalated with and grades laterally through palagonite breccias and tuff into tuffaceous sedimentary rocks (unit Ts). Potassium-argon ages ranging from about 4 to 7 Ma indicate unit is mostly of early Pliocene and late Miocene age. Includes Shumuray Ranch Basalt and Antelope Flat Basalt of Kittleman et al. (1965), Grassy Mountain Basalt of Corcoran et al. (1962), Drinkwater Basalt of Bowen et al. (1963), basalt formerly assigned to Danforth Formation by Piper et al. (1939) (Walker, 1979), Hayes Butte Basalt of Hampton (1964), Pliocene and upper Miocene basalt flows capping and interstratified with the Madras (or Deschutes) Formation, and basalt flows interstratified in the Dalles Formation of Newcomb (1966; 1969). 


\section{Tpb - Porphyritic Basalt (Upper Eocene)}

Subaerial lava flows and breccia of porphyritic basalt, minor basaltic andesite, and rare dacite. Includes basalt of Cascade Head (Wells et al., 1983), Yachats basalt (Snavely et al., 1976b), and Goble Volcanic Series (Warren et al., 1945). Also includes camptonitic extrusive rocks (tuff breccia, lapilli tuff, and minor pillow flows) interbedded in Nestucca Formation.

\section{Tub - Basaltic lava flows}

Basaltic and basaltic andesite lava flows and breccia; grades laterally into rare bedded palagonitic tuff and breccia.

\section{Appendix I.6: Quaternary Basalts}

\section{QTb - Basalt (Pleistocene and Pliocene)}

Thin flows and minor flow breccia of open-textured (diktytaxitic) olivine basalt in southeastern part of map area. Locally contains thin interbeds of sedimentary rocks. Grades laterally through palagonite tuff and breccia into sedimentary rocks (unit QTs). 


\section{QTba - Basalt and basaltic andesite (Pleistocene and Pliocene}

Flows, flow breccia, and pyroclastic deposits of the High Cascades Province. Flows are aphanitic to finely crystalline, commonly diktytaxitic, and aphyric to porphyritic. Textures are mostly intergranular grading to intersertal; some andesite flows are finely trachytic and a few basalt flows are subophitic. Phenocrysts, mostly unaltered, include bytownite and labradorite, olivine, calcic augite, and hypersthenes. Flows and breccia form shields, lava cones, and valley fill; in places greatly dissected and modified by glacial and fluvial erosion. Includes Boring Lava of Trimble (1963) and Hampton (1972) and Battle Ax Basalts of Thayer (1936). Potassium-argon ages from this unit range from about 1.2 to $3.9 \mathrm{Ma}$; in places difficult to distinguish from youngest flows of unit Trb.

\section{Qyb - Youngest basalt and basaltic andesite (Holocene)}

Little-modified flows and associated breccia of basaltic andesite and some basalt on slopes of Newberry Volcano. Relations to Mazama pumice deposits indicate most of these rocks are less than $6,800 \mathrm{yr}$ old (14C); isotopic ages on flows range from about 1,000 to 6,000 yr B.P. (14C). Author's Note: Young cinder cones. 


\section{Appendix 1.7: Andesites}

\section{Qa - Andesite (Holocene and Pleistocene)}

Forms major stratovolcanoes dominantly of aphyric to porphyritic basaltic andesite and andesite; phenocrysts are principally pyroxene, olivine, plagioclase, and rarely, hornblende. Locally includes dacite and minor basalt.

\section{Appendix I.8: Rhododendron/Sardine Formations}

\section{Tbaa - Basaltic and andesitic rocks (upper to middle Miocene)}

Lava flows and flow breccia of hypersthene and olivine andesite, basaltic andesite containing plagioclase and pyroxene phenocrysts, and basalt; many flows contain phenocrysts of both hypersthene and augite. Includes interbedded volcaniclastic and epiclastic rocks mostly of andesitic composition, but partly of dacitic or rhyodacitic composition. Includes aerially restricted flows of silicic andesite or dacite. Upper part of unit mostly unaltered, although olivine crystals are locally altered to clay minerals. Lower parts commonly altered; secondary minerals include nontronite and saponite, chalcedony, calcite, and zeolites. Older parts of this unit locally are propylitically altered adjacent to larger intrusions. Erupted mostly from widespread, northwest and north trending dikes and dike swarms and related plugs and lava cones. Potassium argon ages range from about $10 \mathrm{Ma}$ to about $17 \mathrm{Ma}$. Much of this unit was previously assigned to the Sardine Formation (Peck et al. 1964), although the type locality of the Sardine 
Formation ("Sardine Series" as mapped by Thayer, 1939) may be older. Includes Elk Lake Formation (White, 1980a, 1980b), part of the Rhododendron Formation (Trimble, 1963; Wise, 1969) and andesite of Nohorn Creek of Hammond et al. (1982).

\section{Tfc - Flows and clastic rocks, undifferentiated (Miocene)}

Chiefly basaltic andesite and andesite lava flows and flow breccia containing plagioclase and pyroxene (hypersthenes and augite) phenocrysts, mudflows (lahars), and volcanic conglomerates; locally includes some dacite flows. Includes lesser, coarse-to fine grained epiclastic volcanic sedimentary rocks and ash-flow and air-fall tuffs. Partly equivalent in age to unit Tba and may be partly coeval with younger parts of unit Tstb. Locally altered adjacent to larger intrusions. The oldest radiometrically dated rocks assigned to this unit are about $17 \mathrm{Ma}$ (Sutter, 1978); in part lapped by flows questionably assigned to unit Tba, radiometrically dated at about $10 \mathrm{Ma}$, and unconformably overlain by flows of unit Trb. Includes some of rocks formerly mapped as Sardine Formation and some mapped as Rhododendron Formation. 


\section{Appendix 1.9: Volcanic Sediments}

Tca - Clastic rocks and andesite flows (lower Oligocene?, Eocene, and Paleocene?)

Mostly andesitic lava flows, domes, breccia, and small intrusive masses and lesser basaltic to rhyolitic rocks; interlayered saprolite, bedded volcaniclastic and epiclastic mudstone, claystone, siltstone, sandstone, conglomerate, and mudflow (lahar) deposits. Mostly consists of Clarno Formation of central Oregon. Fossil plants and vertebrates in these rocks are Eocene in age. Andesite and basalt lava flows are typically slightly altered; most glass is devitrified and altered to clay minerals, zeolites, and secondary feldspar. Reliable K-Ar ages of rocks from unit range from about $54 \mathrm{Ma}$ to about $37 \mathrm{Ma}$ (Evernden and James, 1964; Fiebelkorn et al., 1983). Although these rocks are lithologically similar to, but generally less altered than, rocks of the Clarno Formation, they are coeval with the John Day Formation. Most of these enigmatic rocks of Oligocene and early Miocene age are included in unit Tas. 


\section{Tus - Sedimentary and volcaniclastic rocks}

Lapilli tuff, mudflow deposits (lahars), flow breccia, and volcanic conglomerate, mostly of basaltic to dacitic composition; rare iron stained palagonitic tuff and breccia of basaltic and andesitic composition; and ash flow, airfall, and water-laid tuff of dacitic to rhyolitic composition. The palagonite tuff and breccia grade laterally into peperite and into lava flows of basalt and basaltic andesite.

Tsfj - John Day Formation of east-central Oregon (lower Miocene, Oligocene, and uppermost Eocene?)

Vent-filling ash-flow tuff is intruded by dacite and rhyolite plugs and dikes and ringed by a belt of rhyolite domes and flows. The caldera margin is coincident with prominent gravity and aeromagnetic anomalies. The volcanic field contains 18 map units that range in composition from basalt to rhyolite.

Tu - Undifferentiated tuffaceous sedimentary rocks, tuffs, and basalt (Miocene and Oligocene)

Heterogeneous assemblage of continental, largely volcanogenic deposits of basalt and basaltic andesite, including flows and breccia, complexly interstratified with epiclastic and volcaniclastic deposits of basaltic to rhyodacitic composition. Includes extensive rhyodacitic to andesitic ash-flow and air-fall tuffs, abundant lapilli tuff and tuff breccia, andesitic to dacitic mudflow (lahar) deposits, poorly bedded to well-bedded, fine- to coarse-grained tuffaceous sedimentary rocks, and volcanic conglomerate. Originally 
included in Little Butte Volcanic Series (Peck et al., 1964); includes Mehama Volcanics and Breitenbush Tuffs or Series of Thayer $(1933,1936,1939)$, Breitenbush Formation of Hammond et al. (1982), Mehama Formation of Eubanks (1960), and Molalla Formation of Miller and Orr (1984). In Columbia River Gorge, includes Miocene and older rocks previously assigned to the Skamania Volcanic Series (Trimble, 1963), or to the Eagle Creek Formation (Waters, 1973). Lower parts of unit exhibit low-grade metamorphism with primary constituents altered to clay minerals, calcite, zeolites (stilbite, laumontite, heulandites), and secondary silica minerals. In contact aureoles adjacent to stocks and larger dikes of granitic and dioritic composition or in areas of andesitic dike swarms, both wallrocks and intrusions are pervasively propylitized; locally, rocks also have been subjected to potassic alteration. Epiclastic part of assemblage locally contains fossil plants assigned to the Angoonian Stage (Wolfe, 1981) or of Oligocene age. A regionally extensive biotite-quartz rhyodacite ash-flow tuff, the ash-flow tuff of Bond Creek of Smith et al. (1982), is exposed in southern part Western Cascade Range near and at base of unit. A K-Ar age of 4.9 Ma was determined on biotite from the tuff (Smith, 1980). Ash-flow tuffs, higher in the section and in the same area, have been radiometrically dated at 22 to 32 Ma by potassium-argon methods (J.G. Smith, unpub. Data; Evernden and James, 1964; Fiebelkorn et al., 1983). In the central part of the Western Cascade Range, the unit has yielded a number of K-Ar ages in the range of about 2 to $19 \mathrm{Ma}$ (Verplanck, 1985, p. 53-54). A fission-rack age of 23.8+/-1.4 Ma was obtained on a red, crystal-rich ash-flow tuff (J.A. Vance, oral commun., 1983) collected at an elevation of about 3,000 ft or U.S. Highway 20 west-southwest of Echo Mountain. Most ages from 
basalt and basaltic andesite lava flows are in the range of about 35 to $18 \mathrm{Ma}$. Locally intruded by small rocks of granitoid rocks and by dikes, sills, plugs and invasive flows of basaltic andesite and basalt; in many places, the intrusions are indistinguishable from poorly exposed interbedded lava flows; K-Ar ages on several of the mafic intrusions or invasive flows are about 27 to $31 \mathrm{Ma}$. 
Appendix J: Soil Arsenic Data from Northwest Oregon

\begin{tabular}{|c|c|c|c|c|c|c|}
\hline $\begin{array}{c}\text { Site } \\
\text { Number }\end{array}$ & $\begin{array}{c}\text { Easting } \\
\text { (UTM } \\
\text { NAD 83) }\end{array}$ & $\begin{array}{c}\text { Northing } \\
\text { (UTM } \\
\text { NAD 83) }\end{array}$ & $\begin{array}{l}\text { Underlying } \\
\text { Unit }\end{array}$ & $\begin{array}{l}\text { A Horizon } \\
\text { As (ppm) }\end{array}$ & $\begin{array}{l}\text { B Horizon } \\
\text { As (ppm) }\end{array}$ & Lithologic Group \\
\hline C1 & 522049 & 5039042 & Qs & 3.44 & 3.32 & $\begin{array}{c}\text { Quaternary/ } \\
\text { Tertiary Sediments } \\
\text { / Sedimentary } \\
\text { Rocks }\end{array}$ \\
\hline $\mathrm{C} 2$ & 503643 & 5046637 & Qs & 3.26 & 5.24 & $\begin{array}{c}\text { Quaternary/ } \\
\text { Tertiary Sediments } \\
\text { / Sedimentary } \\
\text { Rocks }\end{array}$ \\
\hline C3 & 487002 & 5056635 & Tc & 0 & 8.4 & $\begin{array}{c}\text { Columbia River } \\
\text { Basalts }\end{array}$ \\
\hline $\mathrm{C} 4$ & 483559 & 5059728 & Tmst & 3.8 & 20.4 & $\begin{array}{l}\text { Marine Sediments/ } \\
\text { Sedimentary Rocks }\end{array}$ \\
\hline C5 & 475233 & 5076304 & Tco & 3.72 & 3.65 & $\begin{array}{l}\text { Marine Sediments/ } \\
\text { Sedimentary Rocks }\end{array}$ \\
\hline C6 & 478660 & 5065818 & Tco & 3.82 & 4.08 & $\begin{array}{l}\text { Marine Sediments/ } \\
\text { Sedimentary Rocks }\end{array}$ \\
\hline $\mathrm{C7}$ & 473195 & 5069554 & Tco & 3.49 & 7.12 & $\begin{array}{l}\text { Marine Sediments/ } \\
\text { Sedimentary Rocks }\end{array}$ \\
\hline $\mathrm{C} 8$ & 453382 & 5073882 & Ttv & 0 & 0 & $\begin{array}{c}\text { Coast Range } \\
\text { Basalts }\end{array}$ \\
\hline C9 & 447193 & 5082998 & Tss & 6.08 & 14.7 & $\begin{array}{l}\text { Marine Sediments/ } \\
\text { Sedimentary Rocks }\end{array}$ \\
\hline $\mathrm{C} 10$ & 447059 & 5083464 & $\mathrm{Ti}$ & 8.26 & 8.83 & Mafic Intrusions \\
\hline C11 & 429230 & 5090474 & Tms & 6.45 & 8.66 & $\begin{array}{l}\text { Marine Sediments/ } \\
\text { Sedimentary Rocks }\end{array}$ \\
\hline $\mathrm{C} 12$ & 462768 & 5062718 & Ttv & 0 & 0 & $\begin{array}{c}\text { Coast Range } \\
\text { Basalts }\end{array}$ \\
\hline $\mathrm{C} 13$ & 466104 & 4937226 & Tsr & 2.62 & 2.68 & $\begin{array}{l}\text { Coast Range } \\
\text { Basalts }\end{array}$ \\
\hline C14 & 449814 & 4906902 & $\mathrm{Tt}$ & 5.82 & 10.5 & $\begin{array}{l}\text { Marine Sediments/ } \\
\text { Sedimentary Rocks }\end{array}$ \\
\hline C15 & 449880 & 4906339 & $\mathrm{Tt}$ & 5.06 & 7.13 & $\begin{array}{l}\text { Marine Sediments/ } \\
\text { Sedimentary Rocks }\end{array}$ \\
\hline
\end{tabular}

See Chapter 4.4: GROUPINGS FOR STATISTIC ANALYSIS for descriptions of lithologic groups. See Appendix I: Descriptions of Lithology by Lithologic Group for descriptions of geologic units. 
Appendix J: Soil Arsenic Data from Northwest Oregon (Continued)

\begin{tabular}{|c|c|c|c|c|c|c|}
\hline $\begin{array}{c}\text { Site } \\
\text { Number }\end{array}$ & $\begin{array}{c}\text { Easting } \\
\text { (UTM } \\
\text { NAD 83) }\end{array}$ & $\begin{array}{c}\text { Northing } \\
\text { (UTM } \\
\text { NAD 83) }\end{array}$ & $\begin{array}{c}\text { Underlying } \\
\text { Unit }\end{array}$ & $\begin{array}{l}\text { A Horizon } \\
\text { As (ppm) }\end{array}$ & $\begin{array}{l}\text { B Horizon } \\
\text { As (ppm) }\end{array}$ & Lithologic Group \\
\hline M1 & 578682 & 5022223 & Qal & 0 & 0 & $\begin{array}{c}\text { Quaternary/ } \\
\text { Tertiary Sediments } \\
\text { / Sedimentary } \\
\text { Rocks }\end{array}$ \\
\hline $\mathrm{M} 2$ & 581417 & 5018888 & QTba & 3.99 & 3.52 & Quaternary Basalts \\
\hline M3 & 585815 & 5019067 & Qal & 0 & 0 & $\begin{array}{c}\text { Quaternary/ } \\
\text { Tertiary Sediments } \\
\text { / Sedimentary } \\
\text { Rocks }\end{array}$ \\
\hline M4 & 595656 & 5017183 & Qg & 0 & 0 & $\begin{array}{c}\text { Quaternary/ } \\
\text { Tertiary Sediments } \\
\text { / Sedimentary } \\
\text { Rocks }\end{array}$ \\
\hline M5 & 601650 & 5017695 & Qa & 0 & 0 & Andesites \\
\hline M6 & 603308 & 5015023 & Qa & 0 & 0 & Andesites \\
\hline M7 & 602981 & 5005326 & QTba & 0 & 0 & Quaternary Basalts \\
\hline M8 & 637441 & 4933297 & Ts & 0 & 0 & $\begin{array}{c}\text { Quaternary/ } \\
\text { Tertiary Sediments } \\
\text { / Sedimentary } \\
\text { Rocks }\end{array}$ \\
\hline M9 & 639027 & 4933925 & Ts & 0 & 0 & $\begin{array}{c}\text { Quaternary/ } \\
\text { Tertiary Sediments } \\
\text { / Sedimentary } \\
\text { Rocks }\end{array}$ \\
\hline M10 & 647676 & 4940502 & Ts & 0 & 0 & $\begin{array}{c}\text { Quaternary/ } \\
\text { Tertiary Sediments } \\
\text { / Sedimentary } \\
\text { Rocks }\end{array}$ \\
\hline M11 & 639253 & 4960466 & Tsfj & 0 & 2.48 & Volcanic Sediments \\
\hline M12 & 631098 & 4962527 & Tob & 0 & 2.14 & $\begin{array}{c}\text { Columbia River } \\
\text { Basalts }\end{array}$ \\
\hline
\end{tabular}

See Chapter 4.4: GROUPINGS FOR STATISTIC ANALYSIS for descriptions of lithologic groups. See Appendix I: Descriptions of Lithology by Lithologic Group for descriptions of geologic units. 
Appendix J: Soil Arsenic Data from Northwest Oregon (Continued)

\begin{tabular}{|c|c|c|c|c|c|c|}
\hline $\begin{array}{c}\text { Site } \\
\text { Number }\end{array}$ & $\begin{array}{c}\text { Easting } \\
\text { (UTM } \\
\text { NAD 83) }\end{array}$ & $\begin{array}{c}\text { Northing } \\
\text { (UTM } \\
\text { NAD 83) }\end{array}$ & $\begin{array}{c}\text { Underlying } \\
\text { Unit }\end{array}$ & $\begin{array}{l}\text { A Horizon } \\
\text { As (ppm) }\end{array}$ & $\begin{array}{l}\text { B Horizon } \\
\text { As (ppm) }\end{array}$ & Lithologic Group \\
\hline M13 & 623961 & 4971108 & Qgs & 0 & 2.14 & $\begin{array}{c}\text { Quaternary/ } \\
\text { Tertiary Sediments } \\
\text { / Sedimentary } \\
\text { Rocks }\end{array}$ \\
\hline M14 & 627175 & 4980627 & Tca & 0 & 0 & Volcanic Sediments \\
\hline M15 & 630735 & 4982276 & Tsfj & 0 & 0 & Volcanic Sediments \\
\hline M16 & 634767 & 4991684 & Tcg & 0 & 2.43 & $\begin{array}{c}\text { Columbia River } \\
\text { Basalts }\end{array}$ \\
\hline M17 & 620659 & 4995427 & QTba & 0 & 0 & Quaternary Basalts \\
\hline M18 & 564920 & 4952727 & $\mathrm{Tu}$ & 0 & 0 & Volcanic Sediments \\
\hline $\mathrm{M} 20$ & 583707 & 4944123 & QTba & 0 & 0 & Quaternary Basalts \\
\hline M21 & 580192 & 4925274 & QTba & 0 & 0 & Quaternary Basalts \\
\hline M22 & 583605 & 4920961 & Qyb & 0 & 0 & Quaternary Basalts \\
\hline $\mathrm{M} 23$ & 590619 & 4918395 & QTba & 0 & 0 & Quaternary Basalts \\
\hline M24 & 572420 & 4916602 & QTba & 0 & 0 & Quaternary Basalts \\
\hline P1 & 528311 & 5044245 & Qgs & 9.2 & 3.92 & $\begin{array}{c}\text { Quaternary/ } \\
\text { Tertiary Sediments } \\
\text { / Sedimentary } \\
\text { Rocks }\end{array}$ \\
\hline P2 & 554815 & 5018163 & Qgs & 9.23 & 6.55 & $\begin{array}{c}\text { Quaternary/ } \\
\text { Tertiary Sediments } \\
\text { / Sedimentary } \\
\text { Rocks }\end{array}$ \\
\hline P3 & 527879 & 5045407 & Qgs & 12.9 & 3.53 & $\begin{array}{c}\text { Quaternary/ } \\
\text { Tertiary Sediments } \\
\text { / Sedimentary } \\
\text { Rocks }\end{array}$ \\
\hline
\end{tabular}

See Chapter 4.4: GROUPINGS FOR STATISTIC ANALYSIS for descriptions of lithologic groups. See Appendix I: Descriptions of Lithology by Lithologic Group for descriptions of geologic units. 
Appendix J: Soil Arsenic Data from Northwest Oregon (Continued)

\begin{tabular}{|c|c|c|c|c|c|c|}
\hline $\begin{array}{c}\text { Site } \\
\text { Number }\end{array}$ & $\begin{array}{c}\text { Easting } \\
\text { (UTM } \\
\text { NAD 83) }\end{array}$ & $\begin{array}{c}\text { Northing } \\
\text { (UTM } \\
\text { NAD 83) }\end{array}$ & $\begin{array}{c}\text { Underlying } \\
\text { Unit }\end{array}$ & $\begin{array}{l}\text { A Horizon } \\
\text { As (ppm) }\end{array}$ & $\begin{array}{l}\text { B Horizon } \\
\text { As (ppm) }\end{array}$ & Lithologic Group \\
\hline P4 & 528949 & 5042701 & Qs & 13.9 & 5.09 & $\begin{array}{c}\text { Quaternary/ } \\
\text { Tertiary Sediments } \\
\text { / Sedimentary } \\
\text { Rocks }\end{array}$ \\
\hline P5 & 526892 & 5043608 & Qs & 4.51 & 6.47 & $\begin{array}{c}\text { Quaternary/ } \\
\text { Tertiary Sediments } \\
\text { / Sedimentary } \\
\text { Rocks }\end{array}$ \\
\hline P6 & 513128 & 5049466 & Qs & 3.35 & 3.09 & $\begin{array}{c}\text { Quaternary/ } \\
\text { Tertiary Sediments } \\
\text { / Sedimentary } \\
\text { Rocks }\end{array}$ \\
\hline P7 & 520862 & 5042653 & Qs & 3.11 & 2.81 & $\begin{array}{c}\text { Quaternary/ } \\
\text { Tertiary Sediments } \\
\text { / Sedimentary } \\
\text { Rocks }\end{array}$ \\
\hline P8 & 554815 & 5018163 & QTba & 3.6 & 4.92 & Quaternary Basalts \\
\hline P9 & 553925 & 5018732 & QTba & 2.89 & 2.5 & Quaternary Basalts \\
\hline P10 & 551620 & 5019797 & QTba & 3.38 & 3.6 & Quaternary Basalts \\
\hline P11 & 548523 & 5018316 & Qal & 3.1 & 3.24 & $\begin{array}{c}\text { Quaternary/ } \\
\text { Tertiary Sediments } \\
\text { / Sedimentary } \\
\text { Rocks }\end{array}$ \\
\hline P12 & 549544 & 5019348 & QTba & 2.95 & 3.22 & Quaternary Basalts \\
\hline P13 & 541212 & 5027009 & QTs & 3.78 & 3.53 & $\begin{array}{c}\text { Quaternary/ } \\
\text { Tertiary Sediments } \\
\text { / Sedimentary } \\
\text { Rocks }\end{array}$ \\
\hline
\end{tabular}

See Chapter 4.4: GROUPINGS FOR STATISTIC ANALYSIS for descriptions of lithologic groups. See Appendix I: Descriptions of Lithology by Lithologic Group for descriptions of geologic units. 
Appendix J: Soil Arsenic Data from Northwest Oregon (Continued)

\begin{tabular}{|c|c|c|c|c|c|c|}
\hline $\begin{array}{c}\text { Site } \\
\text { Number }\end{array}$ & $\begin{array}{c}\text { Easting } \\
\text { (UTM } \\
\text { NAD 83) }\end{array}$ & $\begin{array}{c}\text { Northing } \\
\text { (UTM } \\
\text { NAD 83) }\end{array}$ & $\begin{array}{c}\text { Underlying } \\
\text { Unit }\end{array}$ & $\begin{array}{l}\text { A Horizon } \\
\text { As (ppm) }\end{array}$ & $\begin{array}{l}\text { B Horizon } \\
\text { As (ppm) }\end{array}$ & Lithologic Group \\
\hline P14 & 518251 & 5054374 & Qal & 2.63 & 2.51 & $\begin{array}{c}\text { Quaternary/ } \\
\text { Tertiary Sediments } \\
\text { / Sedimentary } \\
\text { Rocks }\end{array}$ \\
\hline P15 & 541144 & 5039793 & Qgs & 3.35 & 3.21 & $\begin{array}{c}\text { Quaternary/ } \\
\text { Tertiary Sediments } \\
\text { / Sedimentary } \\
\text { Rocks }\end{array}$ \\
\hline P16 & 523521 & 5039058 & Qs & 3.24 & 4.8 & $\begin{array}{c}\text { Quaternary/ } \\
\text { Tertiary Sediments } \\
\text { / Sedimentary } \\
\text { Rocks }\end{array}$ \\
\hline P17 & 533155 & 5020282 & QTs & 0 & 3.7 & $\begin{array}{c}\text { Quaternary/ } \\
\text { Tertiary Sediments } \\
\text { / Sedimentary } \\
\text { Rocks }\end{array}$ \\
\hline P18 & 533053 & 5020069 & QTba & 3.21 & 3.67 & Quaternary Basalts \\
\hline S2 & 491580 & 4976053 & Tcg & 2.38 & 0 & $\begin{array}{c}\text { Columbia River } \\
\text { Basalts }\end{array}$ \\
\hline S5 & 492013 & 4975264 & Tcg & 2.49 & 0 & $\begin{array}{c}\text { Columbia River } \\
\text { Basalts }\end{array}$ \\
\hline S6 & 491838 & 4977670 & Tcg & 5.25 & 4.99 & $\begin{array}{c}\text { Columbia River } \\
\text { Basalts }\end{array}$ \\
\hline S7 & 496863 & 4976953 & Qal & 3.05 & 2.79 & $\begin{array}{c}\text { Quaternary/ } \\
\text { Tertiary Sediments } \\
\text { / Sedimentary } \\
\text { Rocks }\end{array}$ \\
\hline S8 & 497483 & 4975055 & Qs & 0 & 3.69 & $\begin{array}{c}\text { Quaternary/ } \\
\text { Tertiary Sediments } \\
\text { / Sedimentary } \\
\text { Rocks }\end{array}$ \\
\hline
\end{tabular}

See Chapter 4.4: GROUPINGS FOR STATISTIC ANALYSIS for descriptions of lithologic groups. See Appendix I: Descriptions of Lithology by Lithologic Group for descriptions of geologic units. 
Appendix J: Soil Arsenic Data from Northwest Oregon (Continued)

\begin{tabular}{|c|c|c|c|c|c|c|}
\hline $\begin{array}{c}\text { Site } \\
\text { Number }\end{array}$ & $\begin{array}{c}\text { Easting } \\
\text { (UTM } \\
\text { NAD 83) }\end{array}$ & $\begin{array}{c}\text { Northing } \\
\text { (UTM } \\
\text { NAD 83) }\end{array}$ & $\begin{array}{l}\text { Underlying } \\
\text { Unit }\end{array}$ & $\begin{array}{l}\text { A Horizon } \\
\text { As (ppm) }\end{array}$ & $\begin{array}{l}\text { B Horizon } \\
\text { As (ppm) }\end{array}$ & Lithologic Group \\
\hline S9 & 492343 & 4973847 & Qal & 5.01 & 3.95 & $\begin{array}{c}\text { Quaternary/ } \\
\text { Tertiary Sediments } \\
\text { / Sedimentary } \\
\text { Rocks }\end{array}$ \\
\hline S10 & 498126 & 4969207 & Tc & 5.04 & 4.28 & $\begin{array}{c}\text { Columbia River } \\
\text { Basalts }\end{array}$ \\
\hline S11 & 499150 & 4963674 & Tc & 5.41 & 5.19 & $\begin{array}{c}\text { Columbia River } \\
\text { Basalts }\end{array}$ \\
\hline TR01 & $\begin{array}{l}505693 \\
532794\end{array}$ & $\begin{array}{l}4994240 \\
5020289\end{array}$ & QTb & 3.29 & 3.63 & $\begin{array}{c}\text { Quaternary/ } \\
\text { Tertiary Sediments } \\
\text { / Sedimentary } \\
\text { Rocks } \\
\text { Quaternary Basalts }\end{array}$ \\
\hline TR02 & 538370 & 5032348 & QTb & 1.8 & 1.26 & Quaternary Basalts \\
\hline TR03 & 478253 & 5055388 & $\mathrm{Ti}$ & 2.87 & 1.94 & Mafic Intrusions \\
\hline TR04 & 476365 & 5055716 & $\mathrm{Ti}$ & 2.4 & 2.78 & Mafic Intrusions \\
\hline TR05 & 432411 & 5019746 & Tsd & 10.4 & 12.6 & $\begin{array}{l}\text { Marine Sediments/ } \\
\text { Sedimentary Rocks }\end{array}$ \\
\hline TR06 & 429312 & 5018963 & Tsd & 4.82 & 11.0 & $\begin{array}{l}\text { Marine Sediments/ } \\
\text { Sedimentary Rocks }\end{array}$ \\
\hline TR07 & 425260 & 4990592 & $\mathrm{Tpb}$ & 5.99 & 6.39 & $\begin{array}{c}\text { Columbia River } \\
\text { Basalts } \\
\end{array}$ \\
\hline TR08 & 424371 & 4992681 & $\mathrm{Tpb}$ & 3.28 & 5.02 & $\begin{array}{c}\text { Columbia River } \\
\text { Basalts }\end{array}$ \\
\hline TR09 & 518803 & 4914773 & Tub & 5.48 & 5.31 & $\begin{array}{c}\text { Columbia River } \\
\text { Basalts }\end{array}$ \\
\hline TR10 & 518782 & 4914988 & Tub & 7.2 & 6.52 & $\begin{array}{c}\text { Columbia River } \\
\text { Basalts }\end{array}$ \\
\hline TR11 & 555775 & 4916836 & Tus & 10.5 & 11.3 & Volcanic Sediments \\
\hline TR12 & 560076 & 4915917 & Tus & 4.22 & 4.94 & Volcanic Sediments \\
\hline TR13 & 575374 & 4896162 & Tfc & 1.29 & 1.57 & $\begin{array}{l}\text { Rhododendron/ } \\
\text { Sardine Fm. }\end{array}$ \\
\hline
\end{tabular}

See Chapter 4.4: GROUPINGS FOR STATISTIC ANALYSIS for descriptions of lithologic groups. See Appendix I: Descriptions of Lithology by Lithologic Group for descriptions of geologic units. 
Appendix J: Soil Arsenic Data from Northwest Oregon (Continued)

\begin{tabular}{|c|c|c|c|c|c|c|}
\hline $\begin{array}{c}\text { Site } \\
\text { Number }\end{array}$ & $\begin{array}{c}\text { Easting } \\
\text { (UTM } \\
\text { NAD 83) }\end{array}$ & $\begin{array}{c}\text { Northing } \\
\text { (UTM } \\
\text { NAD 83) }\end{array}$ & $\begin{array}{c}\text { Underlying } \\
\text { Unit }\end{array}$ & $\begin{array}{l}\text { A Horizon } \\
\text { As (ppm) }\end{array}$ & $\begin{array}{l}\text { B Horizon } \\
\text { As (ppm) }\end{array}$ & Lithologic Group \\
\hline TR14 & 575103 & 4898916 & Tfc & 2.1 & 1.92 & $\begin{array}{l}\text { Rhododendron/ } \\
\text { Sardine Fm. }\end{array}$ \\
\hline TR15 & 582877 & 4921228 & Qg & 0.263 & 0.404 & $\begin{array}{c}\text { Quaternary/ } \\
\text { Tertiary Sediments } \\
\text { / Sedimentary } \\
\text { Rocks }\end{array}$ \\
\hline TR16 & 580184 & 4925531 & Qg & 0 & 0.991 & $\begin{array}{c}\text { Quaternary/ } \\
\text { Tertiary Sediments } \\
\text { / Sedimentary } \\
\text { Rocks }\end{array}$ \\
\hline TR17 & 579650 & 4930556 & Tbaa & 1.47 & 1.33 & $\begin{array}{l}\text { Rhododendron/ } \\
\text { Sardine Fm. }\end{array}$ \\
\hline TR18 & 580593 & 4937061 & Tbaa & 1.03 & 1.02 & $\begin{array}{l}\text { Rhododendron/ } \\
\text { Sardine Fm. }\end{array}$ \\
\hline W1 & 519284 & 5025030 & Qal & 7.48 & 8.27 & $\begin{array}{c}\text { Quaternary/ } \\
\text { Tertiary Sediments } \\
\text { / Sedimentary } \\
\text { Rocks }\end{array}$ \\
\hline W2 & 518563 & 5022416 & Tc & 4.32 & 3.4 & $\begin{array}{c}\text { Columbia River } \\
\text { Basalts }\end{array}$ \\
\hline W3 & 517701 & 5013384 & Qs & 3.46 & 3.99 & $\begin{array}{c}\text { Quaternary/ } \\
\text { Tertiary Sediments } \\
\text { / Sedimentary } \\
\text { Rocks }\end{array}$ \\
\hline W4 & 507600 & 5011319 & Qs & 4.64 & 5.29 & $\begin{array}{c}\text { Quaternary/ } \\
\text { Tertiary Sediments } \\
\text { / Sedimentary } \\
\text { Rocks }\end{array}$ \\
\hline W5 & 457126 & 4993949 & Ty & 8.12 & 12.3 & $\begin{array}{l}\text { Marine Sediments/ } \\
\text { Sedimentary Rocks }\end{array}$ \\
\hline
\end{tabular}

See Chapter 4.4: GROUPINGS FOR STATISTIC ANALYSIS for descriptions of lithologic groups. See Appendix I: Descriptions of Lithology by Lithologic Group for descriptions of geologic units. 
Appendix J: Soil Arsenic Data from Northwest Oregon (Continued)

\begin{tabular}{|c|c|c|c|c|c|c|}
\hline $\begin{array}{c}\text { Site } \\
\text { Number }\end{array}$ & $\begin{array}{c}\text { Easting } \\
\text { (UTM } \\
\text { NAD 83) }\end{array}$ & $\begin{array}{c}\text { Northing } \\
\text { (UTM } \\
\text { NAD 83) }\end{array}$ & $\begin{array}{c}\text { Underlying } \\
\text { Unit }\end{array}$ & $\begin{array}{c}\text { A Horizon } \\
\text { As (ppm) }\end{array}$ & $\begin{array}{c}\text { B Horizon } \\
\text { As (ppm) }\end{array}$ & Lithologic Group \\
\hline W6 & 451290 & 4994789 & Tco & 11.5 & 11 & $\begin{array}{c}\text { Quaternary/ } \\
\text { Tertiary Sediments } \\
\text { / Sedimentary } \\
\text { Rocks }\end{array}$ \\
\hline W7 & 509234 & 5016806 & TC & 4.54 & 5.29 & $\begin{array}{c}\text { Columbia River } \\
\text { Basalts }\end{array}$ \\
\hline W8 & 512110 & 5019153 & Tc & 4.83 & 4.86 & $\begin{array}{c}\text { Columbia River } \\
\text { Basalts }\end{array}$ \\
\hline W9 & 515080 & 5016470 & Qs & 5.65 & 5.02 & $\begin{array}{c}\text { Quaternary/ } \\
\text { / Sedimentary } \\
\text { Rocks }\end{array}$ \\
\hline
\end{tabular}

See Chapter 4.4: GROUPINGS FOR STATISTIC ANALYSIS for descriptions of lithologic groups. See Appendix I: Descriptions of Lithology by Lithologic Group for descriptions of geologic units. 
Appendix K: High and Low Values for Samples by Mapping Unit

\begin{tabular}{|c|c|c|c|c|c|c|c|}
\hline $\begin{array}{c}\text { Mapping } \\
\text { Unit }\end{array}$ & $\begin{array}{c}\text { Number } \\
\text { of } \\
\text { Samples }\end{array}$ & $\begin{array}{c}\text { A } \\
\text { Horizon } \\
\text { Low As } \\
\text { Value } \\
\text { (ppm) }\end{array}$ & $\begin{array}{c}\text { A } \\
\text { Horizo } \\
\text { n High } \\
\text { As } \\
\text { Value } \\
\text { (ppm) }\end{array}$ & $\begin{array}{c}\text { A Horizon } \\
\text { Number of } \\
\text { Zeros }\end{array}$ & $\begin{array}{c}\text { B } \\
\text { Horizon } \\
\text { Low As } \\
\text { Value } \\
\text { (ppm) }\end{array}$ & $\begin{array}{c}\text { B Horizon } \\
\text { High As } \\
\text { Value } \\
\text { (ppm) }\end{array}$ & $\begin{array}{c}\text { B Horizon } \\
\text { Number of } \\
\text { Zeros }\end{array}$ \\
\hline Qa & 2 & 0 & 0 & 2 & 0 & 0 & 2 \\
\hline Qal & 7 & 0 & 7.48 & 2 & 0 & 8.27 & 2 \\
\hline $\mathrm{Qg}$ & 3 & 0 & 0.26 & 2 & 0 & 0.99 & 1 \\
\hline Qgs & 5 & 0 & 12.90 & 1 & 2.14 & 6.55 & 0 \\
\hline Qs & 12 & 0 & 13.90 & 1 & 2.81 & 6.47 & 0 \\
\hline QTb & 2 & 1.80 & 3.29 & 0 & 1.26 & 3.63 & 0 \\
\hline Qtba & 12 & 0 & 3.99 & 6 & 0 & 4.92 & 6 \\
\hline QTs & 2 & 0 & 3.78 & 1 & 3.53 & 3.70 & 0 \\
\hline Qyb & 1 & 0 & 0 & 1 & 0 & 0 & 1 \\
\hline Tbaa & 2 & 1.03 & 1.47 & 0 & 1.02 & 1.33 & 0 \\
\hline Tc & 6 & 0 & 5.41 & 1 & 3.40 & 8.40 & 0 \\
\hline Tca & 1 & 0 & 0 & 1 & 0 & 0 & 1 \\
\hline Tcg & 4 & 0 & 5.25 & 1 & 0 & 4.99 & 2 \\
\hline Tco & 4 & 3.49 & 11.50 & 0 & 3.65 & 11.00 & 0 \\
\hline Tfc & 2 & 1.29 & 2.10 & 0 & 1.57 & 1.92 & 0 \\
\hline
\end{tabular}

1. It is not known if these are high and low values for individual sampling sites.

2. Refer to section 5.4: A VS B HORIZON ANALYSIS for more detail.

3. Refer to Appendix I: Descriptions of Lithology by Lithologic Group for descriptions of geologic units. 


\section{Appendix K: High and Low values for Samples by Mapping Unit}

\begin{tabular}{|c|c|c|c|c|c|c|c|}
\hline $\begin{array}{l}\text { Mapping } \\
\text { Unit }\end{array}$ & $\begin{array}{c}\text { Number } \\
\text { of } \\
\text { Samples }\end{array}$ & $\begin{array}{c}\text { A } \\
\text { Horizon } \\
\text { Low As } \\
\text { Value } \\
\text { (ppm) }\end{array}$ & $\begin{array}{c}\text { A } \\
\text { Horizo } \\
\text { n High } \\
\text { As } \\
\text { Value } \\
\text { (ppm) }\end{array}$ & $\begin{array}{l}\text { A Horizon } \\
\text { Number of } \\
\text { Zeros }\end{array}$ & $\begin{array}{c}\text { B } \\
\text { Horizon } \\
\text { Low As } \\
\text { Value } \\
\text { (ppm) }\end{array}$ & $\begin{array}{c}\text { B Horizon } \\
\text { High As } \\
\text { Value } \\
\text { (ppm) }\end{array}$ & $\begin{array}{c}\text { B Horizon } \\
\text { Number of } \\
\text { Zeros }\end{array}$ \\
\hline $\mathrm{Ti}$ & 3 & 2.40 & 8.26 & 0 & 1.94 & 8.83 & 0 \\
\hline Tms & 1 & 6.45 & 6.45 & 0 & 8.66 & 8.66 & 0 \\
\hline Tmst & 1 & 3.80 & 3.80 & 0 & 20.40 & 20.40 & 0 \\
\hline Tob & 1 & 0 & 0 & 1 & 2.14 & 2.14 & 0 \\
\hline Tpb & 2 & 3.28 & 5.99 & 0 & 5.02 & 6.39 & 0 \\
\hline Ts & 3 & 0 & 0 & 3 & 0 & 0 & 3 \\
\hline Tsd & 2 & 4.82 & 10.40 & 0 & 10.96 & 12.60 & 0 \\
\hline Tsfj & 2 & 0 & 0 & 2 & 0 & 2.48 & 1 \\
\hline Tsr & 2 & 2.62 & 2.74 & 0 & 0 & 2.68 & 1 \\
\hline Tss & 1 & 6.08 & 6.08 & 0 & 14.70 & 14.70 & 0 \\
\hline $\mathrm{Tt}$ & 2 & 5.06 & 5.82 & 0 & 7.13 & 10.50 & 0 \\
\hline Ttv & 2 & 0 & 0 & 2 & 0 & 0 & 2 \\
\hline $\mathrm{Tu}$ & 1 & 0 & 0 & 1 & 0 & 0 & 1 \\
\hline Tub & 2 & 5.48 & 7.20 & 0 & 5.31 & 6.52 & 0 \\
\hline Tus & 2 & 4.22 & 10.50 & 0 & 4.94 & 11.30 & 0 \\
\hline Ty & 1 & 8.12 & 8.12 & 0 & 12.30 & 12.30 & 0 \\
\hline
\end{tabular}

1. It is not known if these are high and low values for individual sampling sites.

2. Refer to section 5.4: A VS B HORIZON ANALYSIS for more detail.

3. Refer to Appendix I: Descriptions of Lithology by Lithologic Group for descriptions of geologic units. 


\section{Appendix L: Outline Illustrating Outcomes of Stated Goals}

1. Obtained soil samples from above as many major geologic formations in my study area as possible.

a. Figure 9: Location of sites sampled during Phase II (2010) fieldwork along with geologic unit associations. Unit labels and descriptions after Walker and MacLeod, 1991.

b. Appendix C: Site Observations for Phase I (1995) Sites (Ashbaugh, 1995)

c. Appendix D: Description of Phase I Soil Samples (Ashbaugh, 1995)

d. Figure 10: Geographic extent of lithologic groups and all site locations (Walker and MacLeod, 1991; Ashbaugh, 1995).

e. Appendix E: Site Observations for Phase II (2010) Sites

f. Appendix F: Description of Phase II Soil Samples (2010)

g. Appendix G: Site and Soil Pit Images from Sites Sampled During Phase II Sampling (2010)

2. Determined the arsenic content of the sampled soils and

3. Produced a database of soil arsenic values

a. Appendix J: Soil Arsenic Data from Northwest Oregon

4. Analyzed the data for significant trends.

a. Statistically evaluate data to determine connections between the measured level of arsenic in soils above similar rock types

i. Table 8: A Horizon data ANOVA

ii. Figure 11: Stem-box plot showing mean, upper and lower quartile, data range, and outliers for the A horizon values of the five tested groups.

iii. Figure 13: Multiple comparison of $A$ horizon arsenic concentrations finds that group MS is distinct from group QB in this horizon.

iv. Table 9: B Horizon data ANOVA

v. Figure 12: Stem-box plot showing mean, upper and lower quartile, data range, and outliers for the $B$ horizon values of the five tested groups.

vi. Figure 14: Multiple comparison of B horizon arsenic concentrations finds that group MS is distinct from all other tested groups in this horizon.

vii. Table 10: A Horizon Data Kruskal-Wallis Analysis

viii. Figure 15: Multiple comparison test of $A$ horizon data based on the Kruskal-Wallis analysis. This test shows the arsenic levels of group MS are statistically different from those of groups $Q B$ and $Q T S$ in the $A$ horizon. The $X$ axis values represent the mean and standard deviation of the group's ranks.

ix. Table 11: B Horizon Kruskal-Wallis Analysis 
x. Figure 16: Multiple comparison test of B horizon data based on the Kruskal-Wallis analysis. This test shows the arsenic levels of group MS are statistically different from those of groups QB, QTS and VS in the B horizon. The X-axis values represent the mean and standard deviation of the group's ranks.

xi. Figure 27: Bar graph connecting lithologic groups (X-axis) to the groups resulting from the three group cluster analysis (color symbology). Color symbology reflects clusters noted in Figure 21 and Figure 22.

xii. Figure 28: Bar graph connecting lithologic groups (X-axis) to the groups resulting from the four group cluster analysis (color symbology). Color symbology reflects clusters noted in Figure 23 and Figure 24.

xiii. Figure 29: Bar graph connecting lithologic groups (X-axis) to the groups resulting from the five group cluster analysis (color symbology). Color symbology reflects clusters noted in Figure 25 and Figure 26.

b. Statistically evaluate the data to determine connections between the measured arsenic level of soils in the $A$ and $B$ horizon.

i. Table 13: A vs B Horizon data ANOVA

ii. Figure 18: Stem-box plot showing mean, upper and lower quartile, data range, and outliers for $A$ and $B$ horizon data by lithologic group. X-Horizon labels indicate lithologic group and horizon.

iii. Figure 19: The standard ANOVA multiple comparison test indicates that group MS in the A horizon is distinct from group $\mathrm{QB}$ in the $\mathrm{A}$ and $\mathrm{B}$ horizon. Group $\mathrm{MS}$ in the $\mathrm{B}$ horizon is distinct from all other tested groups.

iv. Table 14: A vs B Horizon Kruskal-Wallis Analysis

v. Figure 20: The Kruskal-Wallis multiple comparison test indicates group $\mathrm{MS}$ in the $\mathrm{A}$ horizon is distinct from group $\mathrm{QB}$ in both the $A$ and $B$ horizon. Group $M S$ in the $B$ horizon is distinct from groups QB, QTS and VS in the A and $B$ horizons.

5. Mapped the arsenic values using GIS in a scientifically appropriate manner based on the conducted statistical analysis.

a. Table 12: Basic arsenic statistics of groups mapped based on analysis

b. Figure 17: Map showing the distribution of Marine Sedimentary and Sedimentary Rocks group units and the other tested lithologic groups throughout the northwest Oregon study area. This map illustrates areas where soil arsenic content is statistically distinct (Walker and MacLeod, 1991). 